\title{
Site U1344'
}

\author{
Expedition 323 Scientists $^{2}$
}

\section{Chapter contents}

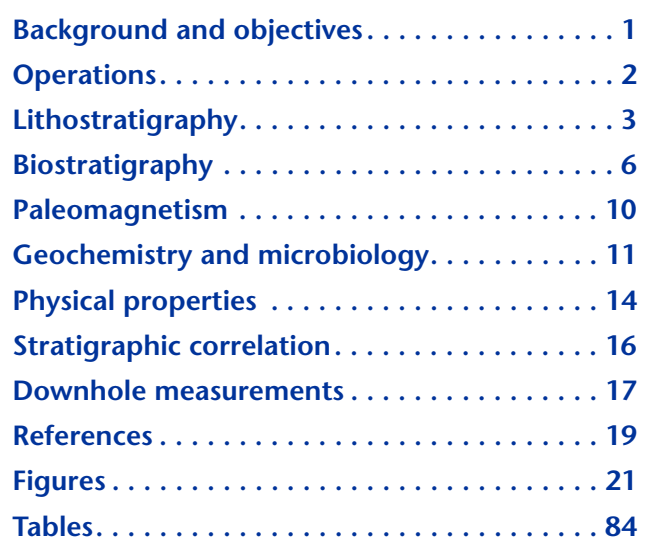

${ }^{1}$ Expedition 323 Scientists, 2011. Site U1344. In Takahashi, K., Ravelo, A.C., Alvarez Zarikian, C.A., and the Expedition 323 Scientists, Proc. IODP, 323: Tokyo (Integrated Ocean Drilling Program Management International, Inc.). doi:10.2204/iodp.proc.323.108.2011

2Expedition 323 Scientists' addresses.

\section{Background and objectives}

The primary objective of drilling at Integrated Ocean Drilling Program (IODP) Site U1344 (proposed Site GAT-3C; Takahashi et al., 2009) was to study high-resolution Pliocene-Pleistocene paleoceanography at a location proximal to the gateway to the Arctic Ocean at the deepest water depth of IODP Expedition 323. Site U1344 is located at a depth of $\sim 3200 \mathrm{~m}$ along the small summit of a canyon interfluve $\sim 10-15 \mathrm{~km}$ southeast of Pervenets Canyon, a large submarine canyon that deeply and widely incises the Beringian continental slope (Figs. F1, F2, F3, F4, F5) (Normark and Carlson, 2003). Pervenets Canyon, along with Zhemchug Canyon, adjacent to IODP Site U1343, was discovered in the early 1960s by the Soviet fishing industry and named after one of the trawlers that found it. It is commonly presumed that at times of glacially lowered sea level the head of Pervenets Canyon was one of the outfall locations for the Anadyr River, which presently drains the Russian northeast and enters the Bering Sea at the Gulf of Anadyr. This location was anticipated to have received a supply of terrigenous sediment from the shelf during both interglacials and glacials.

Site U1344 is located in an area of high biological productivity called the "Green Belt." The Green Belt is formed by the Bering Slope Current (BSC), which originates from the Alaskan Stream water that flows into the Bering Sea through the western Aleutian Islands. The water that enters the Bering Sea moves eastward along the Aleutian Islands and consequently impinges upon the Bering shelf break. The bottom depth of the BSC is $\sim 300 \mathrm{~m}$, and its flow is forced to turn to the northwest once it meets the slope and shelf; eddies and instabilities in its flow cause upwelling along the shelf break. Moreover, tidal mixing causes further vertical mixing of the water masses along the BSC, enhancing biological productivity within the Green Belt (Taniguchi, 1984; Springer et al., 1996), which is adjacent to the northwest-trending shelf break, where high primary productivity in the surface waters and high organic carbon accumulation at the seafloor take place (Springer et al., 1996). However, because of Site U1344's deep water depth, organic carbon supply to the seafloor was expected to be lower here than at other gateway sites or Site U1339. Thus, expectations for this site recording conditions in the oxygen minimum zone (OMZ) were relatively low. Instead, Site U1344 serves as the deep end-member site, where deepwater conditions of the 
Bering Sea can be studied and against which data from shallower sites can be compared to obtain a history of changes in the vertical gradients of oceanic conditions.

Site U1344 is also located close to the maximum extent of present-day seasonal sea ice cover. Thus, this site was expected to have been covered by seasonal or perennial sea ice during glacial lowstands. Because it is adjacent to the Bering shelf, a high amount of terrigenous sediment supply was expected, especially during glacial lowstands.

This relatively deep drill site in the gateway region to the Arctic Ocean can also be used to study the impact of subseafloor microbes on biogeochemical fluxes in the highest surface-ocean productivity areas of the drill sites in the Bering Sea. Organic-fueled subseafloor respiration and its impact on sediment geochemistry in such a highly productive region have not previously been quantified. To do so, drilled sediments in the gateway region were used to determine subseafloor cell abundances and to investigate the link between the mass and characteristics of subseafloor microbes and the extent of export productivity from the surface ocean.

Sedimentation rates at this site have been estimated at $170-180 \mathrm{~m} / \mathrm{m}$.y. based on earlier site survey piston core studies (Takahashi, 2005; T. Sakamoto et al., unpubl. data). None of the piston cores taken in these studies recovered sections from the Holocene, possibly indicating erosion during the recent past. Thus, before drilling we expected to recover Pleistocene to Pliocene sections.

\section{Operations}

Five holes were cored at Site U1344 (Table T1). Hole U1344A used the advanced piston corer (APC) and extended core barrel (XCB) systems to core to $745.0 \mathrm{~m}$ drilling depth below seafloor (DSF). Hole U1344A was then successfully logged with the triple combination (triple combo) and Formation MicroScanner (FMS)-sonic logging tool strings. The second hole, planned as a dedicated microbiology hole, was cut short because of contamination caused when the core liner split during mudline coring. Therefore, Hole U1344C was assigned to microbiology. Hole U1344D was cored with the APC system to $286.5 \mathrm{~m}$ DSF. The last hole, Hole U1344E, was cored with the APC system to $202.8 \mathrm{~m}$ DSF. A complete set of sitespecific tide tables provided by the science party was used to make adjustments relative to the initial mudline core and for each successive core in each hole. Coring was generally routine except for encountering biogenic methane in the cores, which complicated the curation of all cores at this site. APC coring for Site U1344 totaled 87 cores, $781.8 \mathrm{~m}$ penetrated, and $791.1 \mathrm{~m}$ recovered, for $101.2 \%$ core recovery. XCB coring for Site U1344 totaled 52 cores, $489.9 \mathrm{~m}$ penetrated, and $384.1 \mathrm{~m}$ recovered, for $78.4 \%$ core recovery. The total cored interval for Site U1344 was $1271.7 \mathrm{~m}$, with $1175.2 \mathrm{~m}$ of core recovered, for a $92.4 \%$ total core recovery. The time spent at Site U1344 was 8.5 days.

\section{Hole U1344A}

The first APC barrel recovered $9.1 \mathrm{~m}$ of core, and an official seafloor depth was established at $3183.4 \mathrm{~m}$ drilling depth below rig floor (DRF). Hole U1344A was spudded at $0932 \mathrm{~h}$ on 14 August 2009 (all times are ship local time, Universal Time Coordinated [UTC] - $11 \mathrm{~h}$ ). APC coring using nonmagnetic coring assemblies continued through Core 323-U1344A$26 \mathrm{H}$ to $245.6 \mathrm{~m}$ DSF. At this point, the XCB system was deployed, and coring continued through Core 323-U1344A-79X to $745.0 \mathrm{~m}$ DSF. The coring tools were secured, and the hole was swept clean and displaced with $200 \mathrm{bbl}$ of prepared high-viscosity logging mud. No fill was identified at total depth. The end of pipe (EOP) was placed at $\sim 100.0 \mathrm{~m}$ DSF. Two logging strings were deployed. The triple combo tool string reached the total hole depth of $745 \mathrm{~m}$ wireline log depth below seafloor (WSF), and good-quality logs were obtained. The second logging string consisted of the FMS-sonic tool. This tool string also reached total depth on the first pass but reached only $725 \mathrm{~m}$ WSF on the second pass because hole conditions began to deteriorate. Good data were obtained on both passes. APC core recovery for Hole U1344A was $103.5 \%$, with $264 \mathrm{~m}$ recovered. XCB core recovery for Hole U1344A was 78.4\%, with $384.1 \mathrm{~m}$ recovered. Total core recovery for Hole $\mathrm{U} 1344 \mathrm{~A}$ was $87 \%$, with $648.1 \mathrm{~m}$ recovered.

\section{Hole U1344B}

The vessel was offset $20 \mathrm{~m}$ north of Hole U1344A. Hole U1344B was spudded with the APC system at $1335 \mathrm{~h}$ on 19 August. One APC core was recovered. Unfortunately, Core 323-U1344B-1H came to the surface with a split/damaged core liner and was unfit for microbiological studies.

\section{Hole U1344C}

The first APC barrel recovered $7.12 \mathrm{~m}$ of core, and an official seafloor depth was established at $3184.4 \mathrm{~m}$ DRF. Hole U1344C was spudded at $1505 \mathrm{~h}$ on $19 \mathrm{Au}-$ gust. Both perfluorocarbon (PFT) and microsphere contamination testing methods were deployed. Four APC cores were recovered for microbiological study to $35.6 \mathrm{~m}$ DSF. Average APC core recovery in Hole U1344C was $94.13 \%$, with $33.5 \mathrm{~m}$ recovered. 


\section{Hole U1344D}

The ship was offset $20 \mathrm{~m}$ north of Hole U1344C. The APC was deployed, and Hole U1344D was spudded at $1940 \mathrm{~h}$ on 19 August. The first mudline core recovered $2.73 \mathrm{~m}$ of sediment, and the calculated seafloor was $3185.8 \mathrm{~m}$ DRF. APC coring using nonmagnetic coring assemblies continued through Core 323$\mathrm{U} 1344 \mathrm{C}-25 \mathrm{H}$ to $224.5 \mathrm{~m}$ DSF. At this point, the nonmagnetic coring equipment was changed to the standard APC coring system and coring continued. Coring with the APC system was suspended after Core $323-U 1344 \mathrm{D}-32 \mathrm{H}$ at $286.5 \mathrm{~m}$ DSF. Only two cores, $323-\mathrm{U} 1344 \mathrm{D}-30 \mathrm{H}$ and $32 \mathrm{H}$, required drillover. Overall core recovery for Hole U1344D using the APC coring system was $99.9 \%$, with $286.1 \mathrm{~m}$ recovered.

\section{Hole U1344E}

The ship was offset $20 \mathrm{~m}$ north of Hole U1344D. The first APC barrel recovered $5.3 \mathrm{~m}$ of core, and an official seafloor depth was established at $3185.7 \mathrm{~m}$ DRF. Hole U1344E was spudded at $0750 \mathrm{~h}$ on 21 August. APC coring using nonmagnetic coring assemblies continued through Core 323-U1344E-23H. Coring was uneventful and continuous except for a $3 \mathrm{~m} \mathrm{sec}-$ tion at $3276.5 \mathrm{~m}$ DRF that was drilled at the request of the stratigraphic correlator. APC core recovery for Hole U1344E was 101.4\%, with 202.7 m recovered.

\section{Lithostratigraphy}

Five holes were cored at Site U1344, reaching a maximum depth of 746.59 meters below seafloor (mbsf) in Hole U1344A. Sediments at this site are primarily composed of silt with varying amounts of sand, clay, and diatoms and minor amounts of ash, foraminifers, nannofossils, and sponge spicules. Authigenic carbonates occur frequently at this site in all holes below 50 mbsf. The sediments are predominantly dark/very dark greenish gray to dark/very dark gray. One lithologic unit spanning the early Pleistocene to the Holocene was defined at this site.

\section{Unit I}

\section{Description of unit}

Intervals: Sections 323-U1344A-1H-1, $0 \mathrm{~cm}$, through 79X-CC, $31 \mathrm{~cm}$; 323-U1344D-1H-1, 0 $\mathrm{cm}$, through $32 \mathrm{H}-\mathrm{CC}, 17 \mathrm{~cm}$; and 323-U1344E$1 \mathrm{H}-1,0 \mathrm{~cm}$, through $23 \mathrm{H}-\mathrm{CC}, 29 \mathrm{~cm}$

Depths: Hole U1344A, 0-746.59 mbsf; Hole U1344D, 0-286.27 mbsf; and Hole U1344E, 0211.24 mbsf

Age: Holocene to Pleistocene

Unit I is characterized by two alternating lithologies determined by the proportions of siliciclastic and biogenic grains: (1) diatom-rich or diatom-bearing silts and clays with $<40 \%$ biogenic components and (2) sediments with $>40 \%$ biogenic components that include mixed lithologies of silt/clay and diatoms, diatom ooze, and, rarely, laminated diatom ooze with varying abundances of foraminifers, nannofossils, and sponge spicules (see "Site U1344 smear slides" in "Core descriptions"). These two lithologies alternate on a decimeter to meter scale (Figs. F6, F7, F8). The siliciclastic sediments are mostly diatomrich clayey silt, silty clay, and silt, whereas mixed siliciclastic-biogenic sediments are generally diatom silt and occasionally diatom clayey silt. Siliciclastic and mixed sediments vary in color from very dark greenish gray (10Y 3/1) and dark greenish gray (10Y $4 / 1,5 \mathrm{GY} 4 / 1$, and $10 \mathrm{GY} 4 / 1$ ) to dark gray (5Y $4 / 1$ and $4 / \mathrm{N}$ ) and very dark gray (5Y $3 / 1$ and $3 / \mathrm{N})$. Diatom oozes are generally olive $(5 \mathrm{Y} 4 / 3)$ to olive-gray (5Y 4/2) and dark greenish gray (10Y 4/1 and 5GY 4/ $1)$. The boundaries between lithologic changes are usually gradational, and color and texture changes are very subtle. However, there are also several sharp boundaries, which are often associated with the lower boundaries of ash or sand layers. No visible soft-sediment deformation was observed at this site.

Similar to Site U1343, foraminifers, nannofossils, and sponge spicules in the main lithologies are generally rare $(<5 \%)$. Sponge spicules occur as sponge spicule aggregates throughout the cores and are cylindrical with a central cavity (often filled with sediment; Fig.F9). Sponge spicule aggregates are concentrated at four depth intervals in Hole U1344A: between $\sim 40$ and 80, 180 and 260, 400 and 480, and 560 and 680 mbsf.

The siliciclastic fraction is composed of quartz, feldspar, rock fragments (commonly polycrystalline quartz and basalt), mica, and clay minerals. The amount of clay minerals identified in Site U1344 smear slides is similar to that identified at Site U1343 (see "Site U1344 smear slides" in "Core descriptions").

Numerous bivalve shells and shell fragments were found at this site, but these were generally less abundant than at Site U1343. However bivalve shell preservation was excellent in one case, where a complete bivalve shell was found lying open, ventral side up in the core, with the hinges touching (Fig. F10).

Only one diatom-rich laminated interval (Fig. F11) occurs at this site: in Hole U1344A at 5.3 mbsf, in Hole U1344D at $3.5 \mathrm{mbsf}$, and in Hole U1344E at 5.0 mbsf. The laminations are defined by faint color changes. The laminated interval has gradational boundaries with the surrounding lithologies. Other intervals described as laminated in the barrel sheets (Figs. F6, F7, F8; 117.6, 140.7, and 577.5 mbsf) are 
laminated sand layers that compare with similar layers described at Site U1343. Laminations in Hole $\mathrm{U} 1344 \mathrm{~A}$ at 177.6 and $140.7 \mathrm{mbsf}$ are thin and parallel, and the interval has gradational boundaries with other lithologies. The laminated sand interval in Hole U1344A, 577.5 mbsf, shows thick, wavy laminations and a sharp base.

Sediments at Site U1344 are soft in Hole U1344A down to $255 \mathrm{mbsf}$, stiff between 255 and $280 \mathrm{mbsf}$, and soft again down to 622 mbsf. Farther downhole they vary between soft and stiff. Other minor variations in lithification, which can be linked to drilling disturbances created by XCB coring (e.g., biscuits of stiff sediment with soft to soupy material in between), were also noted. Notably, APC refusal at Site U1344 was reached at 270 mbsf in an interval of stiff sediments.

Bioturbation is slight to moderate throughout the cores apart from the laminated intervals, where bioturbation is absent. Note that in XCB-cored sediments with faint color variations it is generally difficult to distinguish the degree of bioturbation. Mottling of sediment with different colors or textures is common throughout Site U1344. Many of the dark gray lithologies contain black streaky mottles that may be related to pyrite content, and dark green mottles likely contain glauconite (Section 323U1344A-70X-7) (see XRD in "Supplementary material"). Site U1344 also has numerous sandy patches and layers (Fig. F12), which sometimes contain a higher ratio of polycrystalline quartz than is otherwise observed in the sediment. Both sandy patches and layers are concentrated mainly at four depth intervals in Hole U1344A: between $\sim 45$ and 80, 190 and $255, \sim 400$ and 485 , and 675 and $715 \mathrm{~m}$ core composite depth below seafloor (CCSF-A). The three uppermost intervals overlap intervals rich in sponge spicule aggregates.

Many accessory sediment components were described at Site U1344. Subrounded to well-rounded clasts occur frequently and are usually granule to pebble sized. The clasts are often black and fine grained and composed of either basalt or quartzite. Notably large clasts include a $4 \mathrm{~cm}$ rounded plutonic pebble and an $8 \mathrm{~cm}$ plutonic cobble (both diorite) found in Cores 323-U1344A-65X and 69X, respectively (see "Site U1344 thin sections" in "Core descriptions;" Fig. F13). The large clast recovered in the core catcher of Core 323-U1344A-69X may have been the cause of no recovery in Cores 323-U1344A66X and 67X. Although some intervals have higher clast abundances than others, clasts occur throughout the sedimentary record at Site U1344 (Figs. F6, F7, F8).
Ash is less common at this site than at sites farther south. However, several thin ash layers as well as ash-filled mottles were found in all holes at this site. The ash is usually fine-grained and either gray or light olive in color (Fig. F14). Black ash is less common.

Authigenic carbonates occur frequently at Site U1344. Rhombs, acicular crystals, and globular crystals with extreme birefringence were observed in many samples, similar to minerals observed at Site U1343. The sediment containing authigenic carbonates is often slightly lighter or more yellowish than the surrounding sediments (Fig. F15). The shallowest appearance of authigenic carbonate in Hole U1344A is at 52 mbsf (Core 323-U1344A-6H).

As at most previous Expedition 323 sites, the cored sediments were very gassy. The presence of gas in the sediments caused several types of coring disturbance, mostly cracks as wide as several centimeters. In some cases, this affected the stratigraphic integrity of the sediment, as at Sites U1339 and U1343. The sediment at the top of Cores 323-U1344A-7H through $27 \mathrm{H}$ was ejected out of the core barrel by gas expansion, and $20-150 \mathrm{~cm}$ of sediment was extruded onto the deck. This sediment was pushed back into a core liner; however, some sediment pieces may be out of order or upside down. Sediment from either the top or bottom of most cores between Cores 323-U1344A29X and 77X was similarly extruded. Punctures were made in all cores after Core 323-U1344A-2H, causing a potentially significant loss of sediment from extrusion through the punctures. However, punctures were not always noted in core descriptions because they were not always visible on the cut surfaces of the cores. Similar coring disturbances occurred in sediments from all holes at this site. In conclusion, gas expansion features and sediment biscuiting from $\mathrm{XCB}$ coring led to a significant reduction in sediment recovery and core quality, respectively, below 270 mbsf in Hole U1344A (Figs. F6, F7, F8).

\section{Discussion}

Unit I at Site U1344 spans the Holocene to early Pleistocene and is comparable to Unit I defined at other Expedition 323 sites. It is very similar in lithology to Unit I defined at the other Bering Sea margin Sites U1339, U1343, and U1345. However, Site U1344 is distinct because it has an even higher proportion of siliciclastic components and a higher occurrence of sand-sized grains than Site U1343 and, especially, Site U1339. This is probably related to Site U1344's location on the continental slope and its relative proximity to sources of terrigenous sediments from the continental margin, whereas both Sites 
U1339 and U1343 are situated on submarine highs separated from the main continental slope. The siliciclastic layers were probably deposited during glacial sea level lowstands, when large portions of the Bering Sea shelf were subaerial, allowing rivers to transport terrigenous material closer to the shelf edge. This terrigenous material could have then been remobilized farther down the continental slope and redeposited at Site U1344.

Changes in the proportion of siliciclastic and mixed siliciclastic-biogenic sediments are probably related to changes in primary productivity, sea level, the proximity and flux of terrigenous sediments from rivers, and variable delivery of ice-rafted debris (IRD) by ice through glacial-interglacial cycles. Sandy lithologies are concentrated in four relatively distinct intervals in Hole U1344A (Cores 323-U1344A-5H through $8 \mathrm{H}, 21 \mathrm{H}$ through $25 \mathrm{H}, 48 \mathrm{X}$ through $50 \mathrm{X}$, and $74 \mathrm{X}$; Fig. F6). They can be correlated not only between the holes at Site U1344, but also to Site U1343, where four distinctly sandy intervals occur in Cores 323-U1343A-7H, $18 \mathrm{H}$ through $23 \mathrm{H}, 36 \mathrm{H}$ through $52 \mathrm{X}$, and $77 \mathrm{X}$ through $83 \mathrm{X}$. A clear correlation between sand-rich lithologies and isolated clasts (dropstones) is not evident, which suggests that they were not exclusively deposited by the same mechanism. However, isolated clasts may be undersampled in visual core descriptions, whereas continuous sandy layers are easier to recognize.

Isolated clasts (fine pebbles and pebbles) occur throughout all holes at Site U1344 and were probably transported to this site by ice. Although ice can transport clay-, silt-, and sand-sized grains, other mechanisms such as mass gravity flows may also be significant for the transport of sand-sized and smaller grains. The latter mechanism is consistent with the sharp bases and normally graded structure of some of the sand beds. Because the sandy lithologies appear to be clustered in distinct depth intervals at both Sites U1343 and U1344 and include normally graded sandy layers, they may document periods of increased siliciclastic input by mass movements that occurred along large parts of the northwest Bering Sea shelf break. Such depositional events may have been triggered by the melting of land ice, leading to strong river erosion and runoff during deglaciation periods or at the start of the following interglacial. Furthermore, according to VanLaningham et al. (2009), the siliciclastic flux to this site may have been influenced by the trajectory of the Yukon River, the largest source of sediment to the modern Bering Sea. Yukon-source sediment appears to have been transported southward through the Kamchatka Strait during glacial periods and northward through the Bering Strait during interglacials (VanLaningham et al., 2009). The path of the Yukon across the shelf during glacials is unknown, and sites close to the mouth of the Yukon River would presumably have had much greater sediment accumulation than locations more distal to the sediment source.

The lithologies dominated by diatoms are associated with changes in color reflectance (i.e., higher $b^{*}$ values) (Figs. F6, F7, F8). This is analogous to the changes in diatom abundance and color reflectance parameter $b^{*}$ at other sites (see the "Site U1339," "Site U1341," "Site U1342," and "Site U1343" chapters); however, it is subtler here because of the overall higher abundances of siliciclastic detritus, that is, a stronger dilution of the biogenic signal. The higher abundance of diatoms may reflect high diatom flux during interglacials, as previously observed in the Bering Sea (Okazaki et al., 2005). Alternatively, the input of detrital material may have been reduced during interglacials because of the higher sea level and more distal coastline. However, in contrast to previous sites, no laminated intervals dominated by biogenic components were found at Site U1344. This finding is probably related to the position of Site U1344 below the depth at which the OMZ impinges on the northwest Bering Sea slope. Therefore, we expect that there was well-oxygenated bottom water throughout the Pleistocene. It is thus very intriguing that thin laminated intervals occur at Site U1344. Future study will hopefully illuminate how these laminae were preserved.

Lithologies composed only of diatom ooze were described in a few instances, mostly in the uppermost part of the sediment record at this site. A possible explanation for the relatively low number of diatoms in the sediment could be Site U1344's location at the foot of the continental slope, which likely receives a large proportion of detrital material that dilutes the biogenic component (see discussion above). Alternatively, this site could have been influenced by lower surface productivity that resulted in a lower export of biogenic opal to the seafloor. The greater water depth of Site U1344 could explain why the abundance of biogenic carbonate is generally lower than that at Site U1343, especially in the lower part of the record, because Site U1344 may be affected by stronger calcite-undersaturated, and hence more corrosive, bottom waters. However, lower export productivity may also have contributed to the lower abundance of biogenic carbonate at Site U1344.

The lack of diatom ooze may also explain why APC refusal at Site U1344 was met in Core 323-U1344A$27 \mathrm{H}$, about $100 \mathrm{~m}$ shallower than the depth of re- 
fusal at Site U1343. Also, overall lower porosity (see "Physical properties") could be related to the lack of high-porosity diatom oozes.

Interestingly, despite fewer biogenic remains in Site U1344 sediments and a very clear dominance of siliciclastic material, whitish sponge spicule aggregates were still found throughout large parts of the record. The abundance of these aggregates, which are probably remains of agglutinated benthic foraminifers, could hint at different paleoenvironmental conditions, such as bottom water redox conditions, than those at Site U1343. However, this possibility requires further investigation.

As at Site U1343, volcaniclastic material is a minor component of sediment at Site U1344 because this site is more distant from the Aleutian arc. Thin ash layers $(5 \mathrm{~cm})$ occur mostly in the upper part of each hole (above Cores 323-U1344A-25H and 323U1344D-28H), as do ash-filled mottles, which probably represent bioturbated traces of ash layers. As at Site U1343, the ash is typically lighter in color than ash at the Bowers Ridge or Umnak sites, which is consistent with an explosive rhyolitic source capable of ejecting ash as far as this site.

Similar to Site U1343, many of the isolated clasts found in Site U1344 cores are basalt and may have originated from the Aleutian Islands or older volcanic rocks exposed on continental Alaska. Other pebble compositions include plutonic rocks (e.g., diorite and granodiorite) and quartzite. These pebbles likely originated from the Alaskan landmass and are tentatively classified as dropstones because they are isolated and matrix supported. Almost all dropstones are well rounded, indicating a period of reworking prior to incorporation in the ice. Because clasts associated with continental ice sheets tend to be derived from bedrock via freeze-thaw and ice wedging in periglacial regions or plucking from beneath the ice sheet, they are typically angular or striated rather than well rounded. Rounding therefore favors a coastal provenance and sea ice rafting rather than icebergs (Lisitzin, 2003). The rocks from which these clasts are derived may have been located farther inland, and the clasts could have been transported to the coast via rivers.

There is a shallow sulfate-methane transition zone (SMTZ) and abundant methane in the sediment column at Site U1344, as at the other slope Sites U1339 and U1343 (see "Geochemistry and microbiology"). This is probably a function of high-export production along the Bering slope Green Belt, where there is upwelling of nutrient-rich water due to the interaction of tides and the bottom topography (Springer et al., 1996). Authigenic dolomite, high- magnesium calcite, and aragonite can form from elevated alkalinity in the SMTZ where the vertical methane flux is high (Peckmann and Thiel, 2004). However, distinct and indurated authigenic carbonate layers are absent at Site U1344. Only slightly lighter colored intervals several centimeters thick occasionally occur throughout the sedimentary record. A similar situation with very few lithified dolostone layers was observed at Site U1343, suggesting a potential correlation between high sediment accumulation rates and a lack of distinct, (semi-)lithified authigenic carbonate horizons. In the sediment sections below Core 323-U1344A-24H, finely disseminated authigenic carbonate precipitates of (sub)millimeter size are frequent. In thin sections they are acicular, rhomboid, or square and thus may represent different carbonate minerals and/or different stages of formation. This implies that active diagenetic alteration of the sedimentary record related to organic matter degradation is taking place, but signs of nonsteady-state diagenesis are less pronounced than at Sites U1339, U1340, U1341, and U1342 (see "Geochemistry and microbiology"). Low sedimentation rates never prevailed long enough to fix the SMTZ at a certain depth and precipitate indurated authigenic fronts.

\section{Biostratigraphy}

All core catcher samples from Holes U1344AU1344E were examined for biostratigraphic purposes. Biostratigraphic datums were derived from radiolarian, diatom, dinoflagellate, silicoflagellate, and ebridian bioevents and are summarized in Table T2. The composite age model derived from all five holes shows that the sedimentary record recovered at Site U1344 spans the last 2 m.y. (Fig. F16), yielding a broadly linear trend in sedimentation rates with average values of $\sim 40 \mathrm{~cm} / \mathrm{k} . \mathrm{y}$. Samples from Site U1344 are dominated by diatom assemblages and also contain radiolarians, silicoflagellates, ebridians, organicwalled microfossils (dinoflagellate cysts, pollen, and spores), calcareous nannofossils, and planktonic and benthic foraminiferal assemblages.

The preservation of microfossil groups ranges from very good to poor, with dissolution processes and barren intervals affecting calcareous fossil groups in the lowermost $250 \mathrm{~m} \mathrm{CCSF-A,} \mathrm{probably} \mathrm{related} \mathrm{to}$ dissolution and diagenetic recrystallization. Siliceous, calcareous, and organic fossils have relatively high abundances and show distinct, large-scale oscillations in the uppermost $250 \mathrm{~m}$ CCSF-A (Fig. F17). These microfossil groups possibly reflect fluctuations in sea ice and primary productivity in the upper wa- 
ter column that affect the deepwater environment as well.

\section{Calcareous nannofossils}

All core catcher samples from Holes U1344AU1344E were examined to assess the general abundance and state of preservation of calcareous nannofossils as well as specific marker taxa (Table T3). Site U1344 is characterized by very low calcareous nannofossil abundances; sample abundances range from few to barren, with only three samples (323-U1344A$6 \mathrm{H}-\mathrm{CC}$ and 323-U1344E-6H-CC and 20H-CC) having abundant nannofossils. Barren intervals are common throughout the record and are prevalent in the lower $450 \mathrm{~m}$ of the sequence in Hole U1344A. Coccolithus pelagicus is the most abundant taxon in calcareous nannofossil-bearing samples, followed by the group of small gephyrocapsids; other taxa such as medium gephyrocapsids and Coccolithus leptoporus (normal and small varieties) appear only in very low numbers and at specific intervals. The preservation of all taxa ranges from good to poor, with better preservation in the uppermost $\sim 250 \mathrm{~m}$. Reworked specimens are not abundant at this site and occur irregularly throughout the sequence.

Age-marker species are rare in the calcareous nannofossil record of Site U1344, and no ages were obtained from this group of fossils (Table T2; Fig. F16). Emiliania huxleyi was found only in the uppermost samples of Holes U1344A-U1344D and is always rare (Table T3). Therefore, only Samples 323-U1344A-1HCC, 323-U1344B-1H-CC, 323-U1344C-1H-CC, and $323-\mathrm{U} 1344 \mathrm{D}-1 \mathrm{H}-\mathrm{CC}$ through $4 \mathrm{H}-\mathrm{CC}$ could be assigned to calcareous nannofossil Zone NN21 (Martini, 1971) with an estimated age of younger than 0.29 Ma (Lourens et al., 2004). Because barren samples exist beneath samples bearing $E$. huxleyi, the bottom of Zone NN21 could not be established. Moreover, it is likely that those samples are located within the acme interval of E. huxleyi, which commonly ranges from $0.85 \mathrm{Ma}$ to the present (Thierstein et al., 1977).

\section{Planktonic foraminifers}

All core catcher samples from Holes U1344AU1344E were analyzed for planktonic foraminifers from the $>125 \mu \mathrm{m}$ fraction (Table T4). In addition, mudline samples were analyzed using the same size fraction. All samples contain abundant siliciclastic grains, pyrite, and mica. The samples display relatively high planktonic foraminifer abundance in the uppermost $\sim 260 \mathrm{~m}$. Only a few yellow foraminifer tests were encountered at this site (Table T4). The lower portions in each hole contain fewer plank- tonic foraminifers, and some samples are barren. Only one short continuous barren interval (712$750 \mathrm{~m}$ CCSF-A, at the late Pliocene-early Pleistocene transition) was encountered (Fig. F17). The faunal assemblage found in the uppermost $260 \mathrm{~m}$ is dominated by Neogloboquadrina pachyderma (sinistral) throughout. This polar species also dominates faunal assemblages in the Bering Sea today (Asahi and Takahashi, 2007). Additional species found include the subpolar species Globigerina bulloides, Globigerina umbilicata, and Neogloboquadrina pachyderma (dextral), which also occur in the Bering Sea today (Asahi and Takahashi, 2007). However, these species are less abundant in Site U1344 core samples than they are today. This indicates that conditions were colder during the late Pleistocene, because these species are controlled by sea-surface temperatures (e.g., Bé and Tolderlund, 1971; Asahi and Takahashi, 2007). Below $260 \mathrm{~m}$ CCSF-A, N. pachyderma (sinistral) is less abundant or absent from the faunal assemblages. The assemblages at this depth consist of subpolar species dominated by G. bulloides. This species is characteristic of transitional-polar environments, and its abundance is influenced by food availability and sea-surface temperature (e.g., Reynolds and Thunell, 1985); however, recent studies in the Bering Sea indicate that G. bulloides mainly responds to sea-surface temperature (Asahi and Takahashi, 2007). This shows that the late Pliocene-early Pleistocene was warmer than the late Pleistocene at this site.

\section{Benthic foraminifers}

Around 40 species of benthic foraminifers composing two assemblages were recovered in 138 samples from Holes U1344A-U1344E (Tables T5, T6, T7, T8). These assemblages have relatively low diversity (typically $4-8$ species per sample) and variable abundance (frequent to dominant), with a marked decline in both from around Sample 323-U1344A-32X-CC downhole. Both assemblages are dominated by lowoxygen species and are similar to the assemblages found at Site U1343 (Fig. F18), with the exception of the lack of abundant Islandiella norcrossi and the persistent presence of Melonis pompilioides from Sample 323-U1344A-34X-CC downhole (Fig. F19). Both assemblages have some similarities to assemblages found at Site U1339, within or near the OMZ in the Sea of Okhotsk (Bubenshchikova et al., 2008), and at the Emperor seamounts (Butt, 1980). The variation in species dominance is most likely linked to changes in bottom water oxygenation, with the most important mechanisms probably being surface water productivity and/or deepwater ventilation variability. High-frequency variation in oxygenation is apparent throughout the section, but initial results 
show that the generally higher oxygen indicator $\mathrm{El}$ phidium cf. batialis and possibly M. pompilioides are dominant from Sample 323-U1344A-34X-CC downhole. Melonis pompilioides is more abundant at this site than at any other site and may therefore be a higher oxygen indicator, as all other sites are shallower and more affected by the OMZ today.

\section{Assemblage I (Elphidium-Bulimina)}

Assemblage I is characterized by generally mediumdiversity, high-abundance faunas in samples from the top of the section to Sample 323-U1344A-32X$\mathrm{CC}$, with persistent occurrences of the species Bulimina aff. exilis, Globobulimina pacifica, Cassidulinoides tenuis, and E. cf. batialis (Fig. F18). Other common species include Nonionella labradorica, Nonionella turgida, Uvigerina auberiana, and Valvulineria sp. Fluctuations in the dominance of deep and shallow infaunal species occur and are most likely related to changes in the extent of bottom water oxygen concentrations in association with changes to surface water productivity and/or deepwater ventilation.

\section{Assemblage II (Elphidium-Melonis)}

Assemblage II consists of low-diversity, mediumabundance faunas from Sample 323-U1344A-33XCC downhole and is characterized by the relatively persistent occurrence of $E$. cf. batialis and M. pompilioides (Fig. F18). Other common species include G. pacifica, Valvulineria sp., Cibicidoides mundulus, and C. tenuis. The most dominant species, E. batialis, is regarded as a shallow infaunal species in the Sea of Okhotsk (Bubenshchikova et al., 2008). Melonis pompilioides may also be a higher oxygen indicator because it does not persistently occur in any of the shallow sites.

\section{Ostracodes}

Site U1344 produced five core catcher samples with ostracodes, more than any other site cored during Expedition 323. Samples 323-U1344A-3H-CC, 5H$\mathrm{CC}$, and 22H-CC; 323-U1344C-3H-CC and 4H-CC; and 323-U1344D-13H-CC and 14H-CC contain Krithe, Argilloecia, Munseyella, and one unidentified specimen. Ostracode abundances range from present (1 specimen) to few (5-10 specimens). Preservation varies from very good (transparent) to moderate (white and chalky). Despite their very low numbers, most ostracodes are articulated (full carapace) and well preserved, suggesting that they were in situ and their low numbers are caused by dilution in the sedi- ments. Postcruise examination will allow full taxonomic identification of the unidentified species.

\section{Diatoms}

Diatom biostratigraphy is based on the analysis of core catcher samples from each core from Holes U1344A, U1344D, and U1344E. Depth positions and age estimates of biostratigraphic marker events are shown in Figure F16 and Tables T2, T9, T10, T11, T12, and T13. Diatom preservation is moderate to good in all holes and is common to very abundant throughout the Pleistocene record.

The last occurrence (LO) datums of Proboscia curvirostris and Thalassiosira jouseae were observed in Samples 323-U1344A-12H-6, $70 \mathrm{~cm}$ (118.7 mbsf), 323U1344D-11H-CC (93.2 mbsf), and 323-U1344E-14HCC (117.7 mbsf), giving an age of 0.3 Ma (Barron and Gladenkov, 1995; Yanagisawa and Akiba, 1998). This is consistent with nearby Site U1343 and with Site U1339 on Umnak Plateau. The drilled interval above the LO of $P$. curvirostris is assigned to Neodenticula seminae Zone NPD12. In general, diversity is high for this zone in each hole. The zone is dominated by N. seminae, Actinocyclus curvatulus, Thalassiosira spp. (Thalassiosira antarctica spores and Thalassiosira latimarginata s.l.), Bacteriosira fragilis, Fragilariopsis spp., and, to a lesser extent, Paralia sol and Paralia sulcata.

The last common occurrence (LCO) datum of Actinocyclus oculatus was observed in Sample 323-U1344A$44 \mathrm{X}-\mathrm{CC}$ (409.3 mbsf). Species abundance is low at this site, and therefore this datum may be refined further. Because of the absence of A. oculatus, the bottom ages of Holes U1344D and U1344E were assigned to Zone NPD11.

The first common occurrence (FCO) datum of $P$. curvirostris was defined in Sample 323-U1344A-56X-CC and assigned an age of 1.7-2.0 Ma in the A. oculatus Zone NPD10. This datum was not established through conventional counts because few specimens were observed on the standard smear slides. However, many valves were found on slides prepared for silicoflagellate counts. The $>20 \mu \mathrm{m}$ sieved material concentrated larger diatom valves, and counts were made to obtain the datum (Tables T12, T13). In addition, the LO datum of Stephanopyxis horridus (1.9-2.0 Ma) was defined in Sample 323-U1344A63X-CC. This zone is defined by species $N$. seminae, Porosira glacialis, Stephanopyxis spp. (S. horridus, Stephanopyxis turris, and Stephanopyxis resting spores), $P$. sol, P. sulcata, Thalassiosira spp. (T. antarctica spores 
and T. jouseae), and, to a lesser extent, Delphineis cf. angustata and Coscinodiscus marginatus.

\section{Silicoflagellates and ebridians}

Silicoflagellate and ebridian counting at this site was conducted in Holes U1344A and U1344D (Table T14). However, not all core catcher samples could be counted because of limited time. Therefore, only several intervals with anticipated datum events were examined. The youngest datum, LO of Distephanus octonarius $(0.2-0.3 \mathrm{Ma})$, was estimated in Core 323U1344D-12H (97.86-107.27 mbsf). The LO datum of Dictyocha subarctios (0.6-0.8 Ma) was estimated in Cores 323-U1344A-30H (270.35-280.31 mbsf) and 323-U1344D-26H (224.51-234.09 mbsf). The LO datum of Ammodochium rectangulare (1.9 Ma) is most likely located in Core 323-U1344A-78X (733.13$739.75 \mathrm{mbsf})$. Because of the trace abundances of ebridians in the lower part of Hole U1344E, the LO of $A$. rectangulare may be revised by more detailed shore-based work. Older datum events, such as the LO of Ebriopsis antiqua antiqua (2.47-2.48 Ma), were not observed at this site.

\section{Radiolarians}

Radiolarian biostratigraphy is based on the analysis of core catcher samples from Holes U1344A-U1344E. Radiolarian stratigraphy at Site U1344 (Table T15) extends from the Botryostrobus aquilonaris Zone (upper Quaternary) to the Eucyrtidium matuyamai Zone (middle Quaternary) in the subarctic Pacific (Kamikuri et al., 2007). Five radiolarian datums derived from the subarctic Pacific were identified at this site (Table T15). Estimated sedimentation rates in the uppermost $150 \mathrm{~m}$ of Holes U1344A, U1344D, and U1344E are $>30 \mathrm{~cm} / \mathrm{k} . \mathrm{y}$., which is slightly higher than rates at neighboring Site U1343 ( 20 cm/k.y.). The LO of E. matuyamai (0.9-1.5 Ma) was identified in samples from Hole U1344A, but its first occurrence (FO) datum (1.7-1.9 Ma) was not determined because of very low abundances in the lower interval.

Radiolarian abundances and preservation are shown in Figure F17 and Table T16. In general, both radiolarian abundance and preservation at Site U1344 are lower than at Site U1343. Radiolarian preservation is good to moderate in all samples from the uppermost $300 \mathrm{~m}$. Conversely, preservation in samples below $300 \mathrm{~m}$ CCSF-A is moderate to poor. Radiolarians are mostly common in the uppermost $200 \mathrm{~m}$ in each hole, whereas they are few in the intervals below 200 m CCSF-A in Hole U1344A. Radio- larian assemblages at Site U1344 are mainly composed of typical subarctic Pacific species such as Ceratospyris borealis, Cycladophora davisiana, Sphaeropyle langii-robusta group, Spongotrochus glacialis, and Stylodictya validispina. Radiolarian preservation, abundance, and assemblages are similar to those at neighboring Site U1343. Considering the waterdepth differences between Sites U1343 ( 2000 m) and U1344 $(\sim 3200 \mathrm{~m})$, future work may be able to compare onshore radiolarian data and discuss water mass structural changes.

\section{Palynology: dinoflagellate cysts, pollen, and other palynomorphs}

Palynological assemblages were examined in 70 core catcher samples from Holes U1344A and U1344E (Table T17). The preservation of all palynomorphs is generally good in the uppermost $200 \mathrm{~m}$ and moderate to poor in the lower part. The composition of palynomorphs is very similar to that at Site U1343. Variable numbers of pollen and spores were found throughout the sequence. They are mostly dominated by Picea grains and Sphagnum spores, with concentrations as high as 1600 and 1400 grains $/ \mathrm{cm}^{3}$, respectively. To a lesser extent, freshwater algae Botryococcus and Pediastrum and reworked pre-Neogene palynomorphs also occur throughout the sequence, with concentrations usually of $<400$ grains $/ \mathrm{cm}^{3}$. Analogous to Site U1343, these abundances and the variability of terrestrial compounds likely reflect significant contributions of terrigenous material by atmospheric and/or oceanic circulation.

Dinoflagellate cysts are common to abundant in most samples, with concentrations ranging between $10^{2}$ and $10^{4} \mathrm{cysts} / \mathrm{cm}^{3}$ (Fig. F17). They are, however, very few to rare between 607.6 and 683.6 mbsf. In the uppermost $420 \mathrm{~m}$, the assemblages are dominated by the heterotrophic protoperidinial Brigantedinium spp. or by the polar species Islandinium minutum. Variability in their relative abundances is likely related to changes in surface water conditions between high-productivity and upwelling conditions and pronounced sea ice coverage (see the "Site U1343" chapter). The occasional occurrence of the autotrophic species Operculodinium centrocarpum (Table T17) may be related to oceanic conditions with relatively low productivity. The occurrence of Filisphaera filifera in Sample 323-U1344A-50X-CC (473.4 mbsf) suggests an age of 1.41-1.7 Ma, according to its LO datum in the North Pacific and North Atlantic (Bujak, 1984; M. Smelror et al., unpubl. data). This species dominates the assemblages in a 
few samples above this depth, much like at Site U1343.

\section{Discussion}

As at previous sites, Site U1344 is dominated by siliceous microfossils. Again, the most dominant of these species are diatoms, which have high abundances and are generally well preserved. In contrast, silicoflagellates and ebridians were found in significantly lower abundances, although this did not appear to be due to preservation issues because skeletons were intact and had good preservation. Radiolarians, on the other hand, show moderate to good preservation in the uppermost $\sim 350 \mathrm{~m}$ in all holes and a gradual reduction in both abundance and preservation thereafter. This shift is reflected in the diatom assemblage, whereby open water or icefree water indicator $N$. seminae dominates at this site until 350-400 mbsf, below which it shows a significant decrease that continues to the present day (Fig. F17). The switch in the diatom record to a sea ice species-dominated assemblage suggests a major shift in the climate regime that could be described as intensification to glacial-like conditions. This event is registered at $\sim 1$ Ma and coincides with the mid-Pleistocene Transition (MPT). The increased presence of radiolarians in the sediments after $\sim 1 \mathrm{Ma}$ is also mirrored at Sites U1343 and U1341 and suggests a regional response to these changes in Bering Sea hydrography.

The water depth of Site U1344 is $~ 3200 \mathrm{~m}$, and thus Site U1344 is presently located below the OMZ and can potentially be used to monitor past deepwater changes. Benthic foraminiferal faunas indicate highfrequency changes in the bottom water oxygen content over the entire section, possibly related to surface water productivity, bottom water ventilation changes, and/or methane seeps (Fig. F18). Abundance generally increases from $~ 300$ mbsf to the top of the section (Assemblage I), as does bottom water oxygen variability. The low-oxygen indicator $B$. aff. exilis is abundant at both Sites U1343 and U1344 after $\sim 0.8 \mathrm{Ma}$, along with benthic foraminifer abundance maxima (Fig. F19). Both high-abundance and low-oxygen benthic faunas are common during the last deglacial at Bowers Ridge (Okazaki et al., 2005), and the increase in such characteristics after $0.8 \mathrm{Ma}$ may mark the onset of more intense deglacials, greater nutrient availability, and higher surface water productivity.

The poor preservation below 200 mbsf of organic microfossils, including dinoflagellate cysts, pollen, and spores, is probably related to the depth of this site, which is below the OMZ. Dinoflagellate cysts vary greatly in both abundance and species composition throughout the sequence (Fig. F17). In a few samples below $500 \mathrm{mbsf}$, the dinoflagellate cysts show extremely high production associated with the dominance of the extinct species $F$. filifera.

Calcium carbonate dissolution events are recorded in sediments at Site U1344. The calcareous nannofossil record exhibits the highest abundances in the uppermost $200 \mathrm{~m}$, similar to Site U1343. Large variations in calcareous nannofossil content are displayed in the uppermost $250 \mathrm{~m}$, whereas the lower part is generally characterized by barren samples (Fig. F17). The highest abundances of planktonic foraminifers were encountered in the upper part of the holes corresponding to the late Pleistocene, which supports Zahn et al.'s (1991) conclusion that $\mathrm{CaCO}_{3}$ is preserved under glacial conditions. Because authigenic carbonates are ubiquitously present in the record (see "Lithostratigraphy"), diagenetic dissolution of biogenic carbonate may also be one of the mechanisms controlling the presence of calcareous microfossils. The water depth at this site $(\sim 3200 \mathrm{~m})$ should also be considered as a possible cause of the abundance differences between this site and Site U1343 because carbonate ion concentration drops with water depth. As at Site U1343, the increase of calcareous microfossils also coincides with the highest numbers of sea ice diatoms and polar dinoflagellate cysts after $1 \mathrm{Ma}$. However, planktonic foraminifers are also preserved in the earlier part of the record, and these preserved intervals consist of subpolar species. Changes in calcareous microfossils (Figs. F17, F18, F19) may be explained by the " $\mathrm{CaCO}_{3}$ compensation hypothesis" (Broecker and Peng, 1987), as Okazaki et al. (2005) suggested that $\mathrm{CaCO}_{3}$ preservation peaked during the last deglaciation in the Bering Sea.

\section{Paleomagnetism}

The archive halves of all cores recovered at Site U1344 were measured on the three-axis cryogenic magnetometer. All measurements were done at 2.5 $\mathrm{cm}$ intervals for APC cores and $2.5-5 \mathrm{~cm}$ intervals for XCB cores. Natural remanent magnetization (NRM) was measured before (NRM step) and/or after (demagnetization step) stepwise alternating-field (AF) demagnetization in peak fields up to $20 \mathrm{mT}$. All APC cores from Holes U1344A and U1344B as well as Cores 323-U1344D-1H through $6 \mathrm{H}$ and 323-U1344E$1 \mathrm{H}$ and $2 \mathrm{H}$ were measured at NRM step and $20 \mathrm{mT}$ demagnetization step; other cores from Site U1344 were measured only at $20 \mathrm{mT}$ demagnetization step to keep up with core flow.

Inclination, declination, and intensity after $20 \mathrm{mT}$ AF demagnetization with magnetic susceptibility for Hole U1344A are plotted in Figure F20. Inclination 
and intensity of NRM after $20 \mathrm{mT}$ AF demagnetization with magnetic susceptibility for Holes U1344D and U1344E are plotted in Figure F21. In Figure F20, the declination values of Hole U1344A are plotted as black dots for corrected values using the FlexIt orientation tool and as blue dots for raw values. The corrected declinations cluster well around $0^{\circ}$, indicating that the tool functionally worked at this site. The average inclination values are nearly $70^{\circ}$ over the normal polarity intervals observed in Site U1344 cores, which are close to the site axial dipole inclination $\left(\sim 72^{\circ}\right)$, indicating that overprint magnetization caused by the drill pipe and/or core barrel can be effectively removed from the NRM records.

Both raw and smoothed inclination records from Hole U1344A cores are plotted in Figure F22. The inclination records are so scattered that it is difficult to identify polarity zonations for Hole U1344A cores. However, the inclinations cluster around the site's expected value of $72^{\circ}$ in the uppermost $260 \mathrm{~m}$, which can be assigned to the Brunhes normal polarity zone, as well as in some other intervals below this depth. We used the following procedure to extract "well clustering" inclinations from the original data set without subjectivity. According to paleosecular variation analysis (Merrill and McElhinny, 1983), virtual geomagnetic poles (VGPs) observed at the latitude of this site $\left(\sim 60^{\circ} \mathrm{N}\right)$ should have an angular dispersion of $\sim 20^{\circ}$ that is converted to $\sim 13^{\circ}$ in an angular dispersion of inclination. Average inclinations within $72^{\circ} \pm 13^{\circ}$ were extracted and interpreted to be normal polarity. The results are shown on the barcode-like polarity chart next to the inclination diagram in Figure F22. Normal polarity zones were defined from the polarity chart and the zonation was correlated to the polarity timescale based on micropaleontology datums (see "Biostratigraphy"). The Brunhes/Matuyama boundary is clearly identifiable at 280 mbsf. The Jaramillo, Cobb Mountain, and Olduvai subchrons may correlate with the extracted normal polarity zones placed $\sim 380,420$, and 680 mbsf, respectively. These depths and ages are listed in Table T18 with estimated error depth ranges.

The relative paleointensity of Site U1344 cores was estimated to examine potential geochronological information during the Brunhes Chron. Figure F23 displays magnetic susceptibility (top) and relative paleointensity (bottom) for Hole U1344A. These values are based on the normalization of NRM after $20 \mathrm{mT}$ AF demagnetization step by magnetic susceptibility. The paleointensity variation has large amplitude and obviously shows a coherent change with magnetic susceptibility (Fig. F23), suggesting that the NRM intensity has been largely influenced by environmental change. However, there are differences, and the relative paleointensity pattern is consistent with that seen at Sites U1340, U1341, U1342, and U1343. On the basis of those correlations, we estimated marine isotope Stages (MIS) 1-19 in Figure F23.

The dramatic changes in NRM shown in Figure F20 indicate notable effects of early sediment diagenesis, also noted at previous sites. Significant magnetic mineral dissolution starts within $10 \mathrm{mbsf}$ due to anaerobic oxidation of methane (AOM)-sulfate reduction processes (see "Geochemistry and microbiology"). This is also evident at Sites U1343 and U1339. The active zone of dissolution appears to be limited from the seafloor to a $\sim 10 \mathrm{~m}$ depth interval, so magnetization does not change significantly at deeper depths. This dissolution complicates our ability to make relative paleointensity estimates but does not appear to hinder us from gaining a reliable sense of directional changes, both in secular variation and in polarity.

\section{Geochemistry and microbiology Interstitial water chemistry}

In Hole U1344A, 59 samples for interstitial water analyses were retrieved at a resolution of three samples per core for Core $1 \mathrm{H}$, two samples per core for Core $2 \mathrm{H}$, and one sample per core thereafter to 736.15 mbsf. In addition, high-resolution sampling was conducted at microbiology-dedicated Hole $\mathrm{U} 1344 \mathrm{C}$, totaling 69 whole rounds processed. To prevent oxidation, whole rounds were stored in a nitrogen-filled glove box at $7^{\circ} \mathrm{C}$ until squeezed. Aliquot samples were processed for routine shipboard analyses (see "Geochemistry" in the "Methods" chapter) and collected for shore-based analyses of sulfur and oxygen isotopes of sulfate and hydrogen sulfide, trace metals, dissolved organic carbon (DOC), and fatty acids.

\section{Chlorinity, salinity, alkalinity, dissolved inorganic carbon, and $\mathrm{pH}$}

Chloride concentrations decrease fairly linearly from $590 \mathrm{mM}$ in the top of the sediment column to 482 $\mathrm{mM}$ at 717 mbsf (Fig. F24C). Salinity at Site U1344 generally decreases from $\sim 36$ in the upper sediment column to 33 at $\sim 320$ mbsf and remains at this value downhole to 736 mbsf (Fig. F25I). The salinity profile is fairly similar in shape to the alkalinity and DIC profiles described below.

Alkalinity increases pronouncedly in the uppermost $106 \mathrm{~m}$ from $4.1 \mathrm{mM}$ at $0.05 \mathrm{mbsf}$ to a maximum of $71.1 \mathrm{mM}$ (Fig. F25C). Below $106 \mathrm{mbsf}$, alkalinity concentrations decrease downhole to $362 \mathrm{mbsf}$, below which concentrations are relatively constant, av- 
eraging $19.8 \mathrm{mM}$. This trend is similar to the dissolved inorganic carbon (DIC) profile (Fig. F25A). DIC concentrations reach a maximum of $74.1 \mathrm{mM}$ at $87.78 \mathrm{mbsf}$ and average $20.1 \mathrm{mM}$ between 362 and 736 mbsf. pH varies between 7.5 and 7.9 throughout the sediment column (Fig. F25B).

\section{Dissolved sulfate and hydrogen sulfide}

Interstitial water sulfate concentrations decrease almost linearly from seawater values of $28 \mathrm{mM}$ at 0.05 mbsf to values below detection limit at $8.35 \mathrm{mbsf}$ (Fig. F25D). Hydrogen sulfide has a well-defined concentration peak from 6.75 to 10.85 mbsf, with a maximum of $1.1 \mathrm{mM}$ at $8.35 \mathrm{mbsf}$ (Fig. F25F). Concentrations that are close to detection limit are above and below this peak.

\section{Dissolved ammonium, phosphate, and silica}

Dissolved ammonium concentrations increase with depth from $0.4 \mathrm{mM}$ in the top of the sediment column to a maximum of $11.4 \mathrm{mM}$ at 717 mbsf. The steepest increase is observed in the uppermost $\sim 200 \mathrm{~m}$ (Fig. F25H). Dissolved phosphate concentrations increase with depth to a maximum concentration of $440 \mu \mathrm{M}$ at $144 \mathrm{mbsf}$, below which phosphate concentrations decrease (Fig. F25G). The most pronounced decrease is from 140 to 300 mbsf. Silica is highly scattered but generally increases throughout the sediment column to $1300 \mu \mathrm{M}$ at 736 mbsf (Fig. F24K).

\section{Dissolved calcium, magnesium, sodium, and potassium}

Calcium concentrations decrease from $11 \mathrm{mM}$ in the surface sediment to $3.4 \mathrm{mM}$ at $8.35 \mathrm{mbsf}$ (Fig. F24A). From 12 to 170 mbsf, calcium concentrations are fairly constant. Below $170 \mathrm{mbsf}$, they increase to $9 \mathrm{mM}$ at 736 mbsf. Magnesium concentrations strongly decrease in the uppermost $8 \mathrm{~m}$ of the sediment column, increase to a maximum of $60 \mathrm{mM}$ at $60 \mathrm{mbsf}$, and decrease to $10 \mathrm{mM}$ at $735 \mathrm{mbsf}$ (Fig. F24B). Sodium is fairly constant $(\sim 475 \mathrm{mM})$ throughout the sediment column (Fig. F24D). Potassium concentrations decrease almost linearly with depth to a minimum of $5.2 \mathrm{mM}$ at 682 mbsf (Fig. F24E).

\section{Dissolved manganese, iron, lithium, boron, barium, and strontium}

Dissolved iron is low from the seafloor to $\sim 10 \mathrm{mbsf}$, increasing to $20 \mu \mathrm{M}$ below the hydrogen sulfide peak (Fig. F24H). Iron concentrations increase below 20 mbsf to higher but very scattered values. The dissolved manganese profile decreases in the uppermost
8 mbsf and is below detection limit between 8 and 10 mbsf (Fig. F24G). Manganese concentrations decrease with depth and remain low $(<5 \mu \mathrm{M})$.

Lithium concentrations decrease in the uppermost $10 \mathrm{~m}$ but steadily increase throughout the rest of the sediment column (Fig. F24I). Boron concentrations increase from $405 \mu \mathrm{M}$ at $0.05 \mathrm{mbsf}$ to $1624 \mu \mathrm{M}$ at 736.15 mbsf (Fig. F24J). The most pronounced boron increase is in the uppermost $\sim 20 \mathrm{~m}$. Barium concentrations at this site are the highest of all sites investigated, with values $>80 \mu \mathrm{M}$ below $\sim 300 \mathrm{mbsf}$ (Fig. F24L). Strontium concentrations are highly scattered throughout the uppermost $400 \mathrm{~m}$. Below this depth, strontium concentrations are 80-100 $\mu \mathrm{M}$ (Fig. F24F).

\section{Volatile hydrocarbons}

Samples for volatile hydrocarbon analyses were taken from Hole U1344A at the same resolution as interstitial water samples described above. Methane $\left(\mathrm{C}_{1}\right)$ is detectable throughout Site U1344, except in the uppermost $8 \mathrm{~m}$ of the sediment column (Fig. F25E). Low amounts of ethane $\left(\mathrm{C}_{2}\right)$ were detected below 315 mbsf. Propane was also intermittently detected below 544 mbsf. The headspace $\mathrm{C}_{1} / \mathrm{C}_{2}$ ratios generally decrease with increasing depth and temperature from $>10,000$ in shallow depths to 350 at the bottom of Hole U1344A. The very high ratios indicate biological methane formation.

Sampling of methane from Hole U1344C was performed more efficiently and at a higher resolution than at other sites. Sediment plugs were taken directly from holes drilled in the core liner immediately after the core was brought onto the catwalk. Two cubic centimeters of sediment was placed into vials containing $4 \mathrm{~mL}$ of sodium hydroxide. The vials were immediately capped and stored upside down until they were measured. The holes drilled into the core liner were taped. Methane samples were taken at a resolution of $25 \mathrm{~cm}$ in the uppermost $15 \mathrm{~m}$, avoiding areas of the core that would be sampled for interstitial water and microbiology.

This sampling procedure allowed for a more accurate representation of the methane profile, particularly near the SMTZ. A steep methane concentration gradient was observed between 8 and 13.3 mbsf. At 8 and $13.3 \mathrm{mbsf}$, methane was 0.06 and $14.2 \mathrm{mM}$, respectively. The latter value is the maximum concentration recorded and is likely a minimum estimate of the in situ concentration. At $1 \mathrm{~atm}$ pressure, $5^{\circ} \mathrm{C}$, and a salinity of 35 , the saturation concentration of dissolved methane is $\sim 1.7 \mathrm{mM}$. Higher in situ concentrations in the interstitial water may lead to bubble formation and, consequently, loss of gaseous methane when cores are brought to the surface. Al- 
though sampling was performed immediately after core retrieval, some loss of methane from the interstitial water is evident from the scatter in the profile (Fig. F25E).

\section{Sedimentary bulk geochemistry}

Sixty samples from Hole U1344A were analyzed for solid-phase total carbon (TC), total nitrogen (TN), total sulfur (TS), and total inorganic carbon (TIC). From these analyses, total organic carbon (TOC) and calcium carbonate $\left(\mathrm{CaCO}_{3}\right)$ concentrations were calculated (see "Geochemistry" in the "Methods" chapter). $\mathrm{CaCO}_{3}$ content at Site U1344 ranges from 0.7 to $4.4 \mathrm{wt} \%$ (average $=1.4 \mathrm{wt} \%$ ) (Fig. F26A). TOC and $\mathrm{TN}$ concentrations range from 0.48 to $1.32 \mathrm{wt} \%$ (average $=0.69 \mathrm{wt} \%)$ and from 0.08 to $0.15 \mathrm{wt} \%$ (average $=0.10 \mathrm{wt} \%$ ), respectively (Figs. F26B-F26C). TS contents range from 0.11 to $1.59 \mathrm{wt} \%$ (average = $0.45 \mathrm{wt} \%$ ) (Fig. F26D). Splits of squeeze cakes were also collected and treated for shore-based analyses of bulk elemental composition, iron mineral phases, and iron monosulfide and pyrite content and sulfur isotope composition.

\section{Microbiology}

Samples for community structure and total prokaryotic cell abundance were collected adjacent to interstitial water whole rounds in sections drilled using the APC system. High-resolution sampling took place in the microbiology-dedicated cores, and additional samples were taken once per core to APC refusal. Samples were also taken from XCB Cores 323U1344E-78X through 80X to evaluate prokaryotic cell abundance and community structure in the deepest portion of Hole U1344E. PFT analyses performed on these cores show no contamination from the drill fluid. Samples from all cores were fixed according to the protocol described in "Microbiology" in the "Methods" chapter.

During postcruise study, we will examine microbial activity and diversity in the uppermost $25 \mathrm{~m}$ of sediment. We will focus on the function of Archaea in the uppermost zone of organoclastic sulfate reduction, the SMTZ, and the methanogenesis zone. The SMTZ is a "hot spot" for microbial activity and abundance in the subseafloor (D'Hondt, Jørgensen, Miller, et al., 2003), and we expect an increase in the abundance and activity of microbial life there. To estimate the abundance of living microorganisms, samples were also taken at low resolution for catalyzed reporter deposition-fluorescence in situ hybridization (CARD-FISH) within the three zones and in the deepest section of Hole U1344E.
We will examine bacterial and archaeal diversity by a combination of conventional 16S ribosomal ribonucleic acid (rRNA) clone libraries, quantitative polymerase chain reaction (qPCR), and/or a new quantitative community fingerprinting method involving automated ribosomal intergenic spacer analysis (ARISA) (Ramette, 2009).

\section{Conclusion}

The rate of carbon turnover in the sediment at Site U1344 is similar to or slightly higher than rates at Site U1343, based on similar sulfate, DIC, phosphate, and ammonium concentration profiles. Similar to Site U1343, profiles of methane and sulfate at Site U1344 suggest that sulfate reduction is largely driven by methane diffusing into SMTZ. The methane flux into the SMTZ, as calculated from the concentration gradient between 8 and $13 \mathrm{mbsf}$, is $\sim 70 \%-80 \%$ of the sulfate flux into the SMTZ. The importance of AOM for overall carbon turnover is also stressed by the curvature in the DIC profile. The steepest concentration gradient in the uppermost $10 \mathrm{~m}$ is observed directly above the SMTZ, suggesting that the highest DIC flux occurs in this zone. Preliminary modeling of the DIC profile (data not shown) suggests that net DIC production in the SMTZ accounts for $\sim 80 \%$ of the DIC production in the uppermost $30 \mathrm{~m}$. Hydrogen sulfide concentrations are also at a maximum in the SMTZ because sulfate reduction rates are highest and hydrogen sulfide removal by reaction with reactive Fe (oxyhydr)oxide mineral phases is limited because these mineral phases are depleted, probably due to prior pyritization. Magnetic susceptibility data obtained during the fast scan of the cores confirm low content of oxidized iron in the SMTZ (see "Paleomagnetism").

AOM favors the precipitation of carbonates in the SMTZ. A relatively high flux of calcium into the SMTZ is observed at Site U1344, which indicates the formation of calcium carbonate. There is also a magnesium flux into the SMTZ, which may suggest the formation of a $\mathrm{Mg}$-rich carbonate such as dolomite.

The curvature of the ammonium profile suggests production during organic matter degradation throughout the sediment column. Microbially mediated organic matter degradation occurs through either a respiratory or a fermentative pathway. According to the classic reduction scheme in sediment, only fermentation and hydrogenotrophic methanogenesis occur below the SMTZ; however, at this site, the iron concentration profile suggests that dissimilatory iron reduction may also occur below the SMTZ. 
Organic matter degradation also leads to the accumulation of DIC and phosphate in the interstitial water. The accumulation of these species, however, is much lower than predicted by the ammonium profile, assuming steady state and a constant ratio between carbon, nitrogen, and phosphorus of remineralized organic matter. This suggests both production and consumption of DIC and phosphate in the sediment. Consumption of these species is most likely due to the formation of apatite and calcium carbonates. The interstitial water profiles suggest that rates of net consumption of phosphate and DIC are highest between 300 and 350 mbsf. Calcium and magnesium concentration profiles likewise indicate net consumption of these species between 300 and 350 mbsf.

\section{Physical properties}

Site U1344 is located at a water depth of $\sim 3185 \mathrm{~m}$ along the summit of a canyon interfluve $\sim 10-15 \mathrm{~km}$ southeast of Pervenets Canyon, a large submarine canyon that deeply and widely incises the Beringian margin (Normark and Carlson, 2003). Pervenets Canyon, along with companion Zhemchug Canyon, adjacent to Site U1343, was discovered in the early 1960s by the Soviet fishing industry and named after one of the discovering trawlers. At times of glacially lowered sea level, the head of Pervenets Canyon is commonly presumed to have been one of the outfall locations for the Anadyr River, which presently drains the far Russian northeast and enters the Bering Sea at the Gulf of Anadyr.

Regional studies document that the stratigraphic sequence underlying Site U1344 is $8-10 \mathrm{~km}$ thick and overlies a deeply subsided basement of Mesozoic rock. In the vicinity of nearby Site U1343, the sequence acoustically displays a vertical series of bottom-simulating reflectors (BSRs); the shallowest reflector, at $\sim 350 \mathrm{~m}$, has been linked to the formation of interstitial methane gas hydrate, and a deeper one, at $\sim 1 \mathrm{~km}$, has been linked to the diagenetic transition of opal-A to opal-CT (Cooper et al., 1987). In Hole U1344A, the posited hydrate BSR is acoustically weak, but it can be traced laterally on site survey reflection Record Stk3-7 (Takahashi et al., 2009) to a sloping stack of bright seafloor subparalleling reflection, typical of gas-charged sediment, that crosses upward into the hydrate stability field. Hole U1344A penetrates the putative BSR at $\sim 450 \mathrm{mbsf}$. The in situ temperature calculated at this depth from downhole thermal data is $\sim 22^{\circ} \mathrm{C}$ (see "Downhole measurements"). The ambient temperature and pressure (360-370 bar) are consistent with the phase boundary separating methane hydrate and methane gas.
Five holes, U1344A-U1344E, were drilled at Site U1344. The deepest penetration, $745 \mathrm{mbsf}$, was in Hole U1344A. Only moisture and density (MAD) physical property measurements were made on discrete samples collected from APC and XCB cores recovered at this site (Table T19). A transition from APC to XCB coring occurred at Core 323-U1344A$28 \mathrm{X}$ at $\sim 255$ mbsf. Core-section disruption from expanding gas degraded "fast track" Special Task Multisensor Logger (STMSL) and Whole-Round Multisensor Logger (WRMSL) $P$-wave velocity and gamma ray attenuation (GRA) bulk density logging. $P$-wave velocity scanning was turned off at Core 323U1344A-3H. Gas expansion continued to separate and crack core continuity to the bottom of Hole U1344A.

Similar to the sedimentary sequence cored at Site U1343, the sequence penetrated in Hole U1344A is relatively uniform in lithology and described as one lithologic unit, Unit I (see "Lithostratigraphy"). Unit I is texturally dominated by clayey silt with varying amounts of diatom frustules. Sand, ash, and other microfossils are lesser components.

\section{GRA wet bulk density}

In Hole U1344A, WRMSL GRA readings of wet bulk density exhibit a noisy record of rapid, low-value excursions interpreted to reflect gas-expansion gaps that, which affected all cores to the bottom of the hole at 745 mbsf. The downhole density profile for Hole U1344A is displayed in Figure F27A.

In Figure F27B, the downhole profile of bulk density readings by the triple combo logging tool (below $\sim 100 \mathrm{~m}$ wireline log matched depth below seafloor [WMSF]) reveals interpretable details and evidence of breaks in trends and amplitude and wavelength of oscillations. Breaks in trend are most noticeable at $\sim 250 \mathrm{~m}$ WMSF, coincident with a change from APC to XCB core recovery at $\sim 450 \mathrm{~m}$ WMSF, where the BSR is recorded and associated with an upward shift in average density from $\sim 1.72$ to $1.75 \mathrm{~g} / \mathrm{cm}^{3}$, and at $\sim 620 \mathrm{mbsf}$, where values shift higher to $\sim 1.78 \mathrm{~g} / \mathrm{cm}^{3}$. Below $440 \mathrm{~m}$ WMSF, the wavelength of oscillations broadens and the average amplitude of the swings is higher.

\section{Magnetic susceptibility}

Magnetic susceptibility, as tracked by the WRMSL, exhibits little change in average value and character with depth in Hole U1344A (Fig. F28). The average value is $\sim 50$ SI units, but the range in readings varies from 0 , which probably reflects a gas-expansion air gap, to 250 SI units and a few higher excursions. The spacing between high-value excursions is $\sim 20-40 \mathrm{~m}$, 
but these are superimposed on a longer wavelength of $\sim 80-100 \mathrm{~m}$. No change was noted in the overall pattern at the transition from APC to XCB core recovery ( 250 mbsf) or at the projected position of the BSR ( 450 mbsf). Based on what was learned at previous sites, the rhythmic oscillations are presumed to be a function of lithologic composition and patterns of in situ sediment alteration.

\section{P-wave velocity}

Except in the first three cores from Hole U1344A, Pwave velocity readings for the sedimentary section penetrated in Hole U1344A were only collected by the sonic downhole logging tool (see "Downhole measurements"). Sonic P-wave velocity data shown in Figure F29 reveal a profile similar to that recorded in Hole U1343E in that the average velocity increases downsection in steplike sectors. The upper section records a velocity increase from a near-surface average of $\sim 1550 \mathrm{~m} / \mathrm{s}$ to $\sim 1650 \mathrm{~m} / \mathrm{s}$ at $\sim 230 \mathrm{~m}$ WMSF. After a sharp drop to $\sim 1600 \mathrm{~m} / \mathrm{s}, P$-wave velocity increases steadily from $\sim 1640 \mathrm{~m} / \mathrm{s}$ at $250 \mathrm{~m}$ WMSF to $\sim 1750 \mathrm{~m} / \mathrm{s}$ at $450 \mathrm{~m}$ WMSF, the depth of the acoustically weakly recorded BSR. At $\sim 485 \mathrm{mbsf}, P$-wave velocity drops back to $\sim 1700 \mathrm{~m} / \mathrm{s}$ before resuming its steady increase downhole. A bottom step increase in velocity to $\sim 1800 \mathrm{~m} / \mathrm{s}$ occurs at $\sim 620 \mathrm{mbsf}$, a depth of poor core recovery (Cores 323-U1344A-66X and $67 \mathrm{X})$.

\section{Natural gamma radiation}

Except in the uppermost $\sim 80-100 \mathrm{~m}$, across which natural gamma ray (NGR) readings increase from a near-surface measurement of $\sim 25$ count/s to $\sim 34$ counts/s, NGR values oscillate around an average value of $\sim 30$ counts/s to the bottom of Hole U1344A at 745 mbsf (Fig. F30). The wavelength of the oscillations broadens below the depth of the APC to XCB coring transition ( $250 \mathrm{mbsf})$, but no obvious change occurs at the weak BSR at $~ 450$ mbsf. Variations in NGR presumably reflect downhole changes in clay and siliciclastic mineral content.

\section{Thermal conductivity}

Thermal conductivity was measured on cores recovered from Holes U1344A, U1344B, U1344D, and U1344E. In Hole U1344A, the downsection distribution of thermal conductivity measurements can be grouped into an upper and lower sequence. As shown in Figure F31, the upper vertical sequence has an estimated average reading of $\sim 0.905 \mathrm{~W} /(\mathrm{m} \cdot \mathrm{K})$ and extends downhole from the near surface to 260 mbsf, below which APC refusal caused a change to $\mathrm{XCB}$ coring and $P$-wave velocity shifts abruptly to higher readings (Fig. F29). Thermal conductivity values in the upper group range from readings as low as $\sim 0.8 \mathrm{~W} /(\mathrm{m} \cdot \mathrm{K})$ to highs near $\sim 1.105 \mathrm{~W} /(\mathrm{m} \cdot \mathrm{K})$. The lower group begins near $\sim 280$ mbsf with a shift to an estimated average of $\sim 1.02$ $\mathrm{W} /(\mathrm{m} \cdot \mathrm{K})$, a larger range in low to high excursions, and a longer wavelength of oscillations between them. The average thermal conductivity for the entire section is $\sim 0.910 \mathrm{~W} /(\mathrm{m} \cdot \mathrm{K}$ ) (see "Downhole measurements").

\section{MAD (discrete sample) wet bulk density}

The downhole variability of MAD (discrete sample) wet bulk density is displayed in Figure F32 and listed in Table T19. It is instructive to compare Figure F32 with Figure F27B, which presents downhole density recorded by the Hostile Environment Litho-Density Sonde (HLDS) logging tool. Although the MAD and logging profiles are similar, with the exception of the uppermost $\sim 100 \mathrm{~m}$ of section not recordable by the triple combo tool, some important details were only revealed by the density log (see above). A significant loss of resolution is evident in MAD data below the transition from APC to XCB coring operations at $\sim 250$ mbsf. Because the lithologic character changes little downhole in Hole U1344A, the rapid downhole increase in MAD-measured density from $1.45 \mathrm{~g} / \mathrm{cm}^{3}$ in near-surface sediment to $\sim 1.65 \mathrm{~g} / \mathrm{cm}^{3}$ at $\sim 100$ mbsf is interpreted as a record of early sediment compaction and water expulsion.

\section{MAD porosity and water content}

The downhole distribution of sediment porosity and water content in Figure F33A follows an oscillating but progressive decrease to the bottom of Hole U1344A. Near-surface porosity averages $75 \%$, which is similar to the porosity of nearby Site U1343 and, as described in the "Site U1343" chapter, is distinctly lower than is typical of non-Beringian margin Sites U1339, U1340, U1341, and U1342, all of which are characterized by a sedimentary column richer in diatom content. In Hole U1344A, porosity decreases most rapidly in the upper part of the drilled section, falling to an average of $\sim 60 \%$ at $80-100$ mbsf. Below this depth, values remain fairly uniform.

In Figure F33B, porosity derived from the density log changes in average value and trend. An abrupt shift at $250 \mathrm{~m}$ WMSF to porosity as high as $80 \%$ is due to a borehole washout and is not valid. Below this depth, porosity averages $\sim 60 \%$ from $\sim 300$ to $\sim 440 \mathrm{~m}$ WMSF, where it decreases to an average of $\sim 56 \%$. At greater depths, sediment porosity gradually increases to $\sim 63 \%$ at $620 \mathrm{~m}$ WMSF. At this depth, the trend shifts abruptly to $\sim 55 \%$ and slowly decreases to 
$\sim 52 \%$ at the bottom of Hole U1344A. The lowermost shift in trend at $\sim 620 \mathrm{~m}$ WMSF is coincident with poor core recovery and changes in value and trend of other physical properties (Figs. F27B, F29, F30).

The overall downhole decrease in porosity tracked by MAD and logging data is presumably a manifestation of compaction. Details and offsets in this general trend are linked to lithostratigraphic changes and the influence of diagenetic factors. Downhole rhythmic oscillations from lower to higher porosity and water content readings, which are detected by virtually all other physical properties, likely reflect lithostratigraphic variations.

\section{Grain density}

Except for a few anomalous excursions, grain density can be grouped into three sections of decreasing density with increasing depth (Fig. F34). Similar groupings were identified in Hole U1343E. In Hole U1344A, the average density from the surface to $\sim 160 \mathrm{mbsf}$ is $\sim 2.70 \mathrm{~g} / \mathrm{cm}^{3}$. The middle sequence, $\sim 160-620 \mathrm{mbsf}$, has an average density of $2.65 \mathrm{~g} / \mathrm{cm}^{3}$, and the underlying basal group has a density of $\sim 2.62 \mathrm{~g} / \mathrm{cm}^{3}$. In comparison, the average density groupings in Hole U1343E are, respectively and with increasing depth, $\sim 2.68 \mathrm{~g} / \mathrm{cm}^{3}$ (versus $2.70 \mathrm{~g} / \mathrm{cm}^{3}$ ), $2.65 \mathrm{~g} / \mathrm{cm}^{3}$ (versus $2.65 \mathrm{~g} / \mathrm{cm}^{3}$ ), and $\sim 2.63$ (versus $2.62 \mathrm{~g} / \mathrm{cm}^{3}$ ). Presumably, an overall uphole increase in the deposition of denser siliciclastic mineral debris with decreasing age is recorded at both Beringian margin drilling sites.

\section{Stratigraphic correlation}

The complete and continuous composite depth scale and splice at Site U1344 is constructed from 0.0 to $332.02 \mathrm{~m}$ CCSF-D (as defined in "Stratigraphic correlation" in the "Methods" chapter). Cores below the splice from Hole U1344A (discontinuously with unknown gaps) are appended to the splice from 336.18 to $790.06 \mathrm{~m}$ CCSF-A. Specifically, the continuous splice ranges from the top of Core 323-U1344A$1 \mathrm{H}$ to horizon 31X-5, $50 \mathrm{~cm}$ (332.02 CCSF-A) (Tables T20, T21). The appended cores range from Cores 323-U1344A-32X (336.18 m CCSF-A) through 79X (790.37 m CCSF-A), with a constant affine value of $43.78 \mathrm{~m}$.

Correlations were accomplished using IODP Correlator software (versions 1.656 and 1.657), and some intervals were checked with digital line-scan images with Corelyzer (version 1.3.3). The composite (CCSF-A) and splice (CCSF-D) depth scales are based primarily on the stratigraphic correlation of WRMSL magnetic susceptibility (Fig. F35), WRMSL GRA bulk density (Fig. F36), whole-round NGR (Fig. F37), and color reflectance parameter $b^{*}$ (Fig. F38) data.

The CCSF-A and CCSF-D scales were constructed by assuming that the uppermost sediment (the mudline) in Core $323-\mathrm{U} 1344 \mathrm{~A}-1 \mathrm{H}$ represents the sediment/water interface. The mudline was also recovered in Cores 323-U1344B-1H, 323-U1344C-1H, and 323-U1344D-1H, confirming the fidelity of the top of the recovered section. Core 323-U1344A-1H serves as the anchor in the composite depth scale and is the only core with depths that are the same on the mbsf, CCSF-A, and CCSF-D scales. From this anchor we worked downhole, correlating the variations in core logging data on a core-by-core basis using Correlator.

All splice points in the interval of $0-50 \mathrm{~m}$ CCSF-A are clear and convincing based on multiple data types. The splice tie point between interval 323-U1344A$5 \mathrm{H}-7,40.02 \mathrm{~cm}$, and 323-U1344D-6H-3, $79.90 \mathrm{~cm}$ (51.96 m CCSF-A), is uncertain and could be moved $\sim 2.4 \mathrm{~m}$ shallower in Section 323-U1344D-6H-3 with equal uncertainty. This is a point to be checked with postcruise data. The splice tie points between intervals 323-U1344E-6H-6, $112.50 \mathrm{~cm}$, and 323-U1344A$6 \mathrm{H}-4,122.31 \mathrm{~cm}$ (60.38 m CCSF-A); 323-U1344E14H-7, $12.36 \mathrm{~cm}$, and 323-U1344D-14H-2, $139.17 \mathrm{~cm}$ (140.42 m CCSF-A); and 323-U1334A$16 \mathrm{H}-7,85.09 \mathrm{~cm}$, and 323-U1334D-17H-4, $15.30 \mathrm{~cm}$ (175.51 m CCSF-A), are uncertain because of low signal amplitude in magnetic susceptibility.

The splice tie points between intervals 323-U1344D$25 \mathrm{H}-3,51.30 \mathrm{~cm}$, and 323-U1344A-25H-1, $12.89 \mathrm{~cm}$ (264.94 m CCSF-A), and between 323-U1344A-25H$7,41.54 \mathrm{~cm}$, and 323-U1344D-27H-1, $12.07 \mathrm{~cm}$ (273.67 m CCSF-A), are effectively append points where there is no overlap between cores; however, they are defined here as tie points because Correlator (version 1.656) did not allow floating splice intervals below append points. The tie between intervals 323U1344D-31H-7, $131.47 \mathrm{~cm}$, and 323-U1344A-30X-5, $12.39 \mathrm{~cm}$ (321.49 m CCSF-A), is highly uncertain and should be considered suspect. It is included here only because Correlator allows appended cores below a tied core in the same hole.

Difficulties making many of these tie points arose because of pervasive voids that are apparent as low "spikes" in the GRA bulk density data and, to some extent, in the other data types and also because of a finding that the NGR data contain calibration artifacts within each section (low NGR values near end caps and a characteristic double-peaked pattern within most sections) that preclude the use of NGR data for detailed correlations between holes. 
Within the splice, the composite CCSF-A depth scale is defined as the CCSF-D depth scale. Note that CCSF-D rigorously applies only to the spliced interval. Intervals outside the splice, although available with CCSF-A composite depth assignments, should not be expected to correlate precisely with fine-scale details within the splice or with other holes because of normal variation in the relative spacing of features within cores from different holes. Such apparent depth differences may reflect coring artifacts or finescale variations in sediment accumulation and preservation at and below the seafloor.

The cumulative offset between mbsf and CCSF-A depth scales is roughly linear (Figs. F39, F40). The affine growth factor (a measure of the fractional stretching of the composite section relative to the drilled interval; see "Stratigraphic correlation" in the "Methods" chapter) at Site U1344 is 1.18. A few significant anomalies around this relatively uniform affine growth relationship are unexplained but may indicate uncertainties in the assignment of composite depths. The calculation of mass accumulation rates (MARs) based on the CCSF-A or CCSF-D scales should account for the affine growth factor by dividing apparent depth intervals by the appropriate growth factor. After it is divided by the growth factor (accounting for the different depth intervals), this scaled depth scale should be referred to as CCSF-B.

Cores deeper than the spliced interval (i.e., Cores 323-U1344A-32X [336.18 m CCSF-A] through 79X [790.37 m CCSF-A]) were appended to the splice with a constant affine value of $43.78 \mathrm{~m}$. MARs calculated in this interval should not be divided by the affine growth factor because their depths are a linear transformation of drilling depths.

\section{Downhole measurements}

\section{Logging operations}

Downhole logging of Hole U1344A started after APC/XCB coring to a total depth of $745.0 \mathrm{~m}$ DSF (3928.4 m DRF) and was completed at $1020 \mathrm{~h}$ on 18 August 2009 (all times are ship local time, UTC $11 \mathrm{~h}$ ). In preparation for logging, the hole was conditioned with a $\sim 50$ bbl sweep of high-viscosity mud and displaced with logging mud. The bit was then raised to the logging depth of $99.6 \mathrm{~m}$ DSF (3283 m DRF).

Two tool strings were deployed in Hole U1344A: the triple combo and the FMS-sonic combination (for tool and measurement acronyms, see "Downhole measurements" in the "Methods" chapter). Assembly of the triple combo started at $1515 \mathrm{~h}$, and the string was run in hole (RIH) at $1600 \mathrm{~h}$. The tool string reached the bottom of the hole (total depth = $3928 \mathrm{~m}$ wireline log depth below rig floor [WRF]) and a first short $(\sim 50 \mathrm{~m})$ uphole logging pass started at $1830 \mathrm{~h}$ at a speed of $900 \mathrm{ft} / \mathrm{h}$. After the pass was completed, the triple combo was sent back to total depth, and the main pass started at $1905 \mathrm{~h}$ at the logging speed of $900 \mathrm{ft} / \mathrm{h}$. The pass ended at $2155 \mathrm{~h}$ when the tool string crossed the seafloor, marked by a drop in natural radioactivity at $3184.5 \mathrm{~m}$ WRF, $\sim 1 \mathrm{~m}$ deeper than that detected by the driller. The triple combo reached the rig floor at $0030 \mathrm{~h}, 19 \mathrm{Au}-$ gust, and was rigged down at $0125 \mathrm{~h}$.

Overall, the caliper of the density sonde showed an irregular borehole, with a particularly large interval between 170 and $260 \mathrm{~m}$ WSF but very good conditions in the lower section, indicating that the deployment of the FMS-sonic tool string would provide worthwhile velocity and image data. The tool string was built up and RIH at 0215 h. At $0400 \mathrm{~h}$ it could not pass below $3910 \mathrm{~m}$ WRF (725.5 $\mathrm{m} \mathrm{WSF}$ ), and the first pass started at the logging speed of $1500 \mathrm{ft} / \mathrm{h}$. The pass was complete at $0600 \mathrm{~h}$ with the bottom of the $35 \mathrm{~m}$ long tool string at $3320 \mathrm{~m}$ WRF. While the tool was descending to the bottom of the hole for a second pass, a quick preliminary processing of the FMS electrical images established that the data quality and resolution were not diminished by the faster than normal $(900 \mathrm{ft} / \mathrm{h})$ logging speed, and the second pass started at $0630 \mathrm{~h}$ at $3910 \mathrm{~m} \mathrm{WRF}$ at the same logging speed of $1500 \mathrm{ft} / \mathrm{h}$. It ended at $0805 \mathrm{~h}$ after the last velocity measurements were recorded immediately below the bit. The FMS-sonic tool string was rigged down immediately after reaching the surface at $0940 \mathrm{~h}$, and the rig floor resumed normal operations at $1110 \mathrm{~h}$ to pull out of the hole and begin coring Hole U1344B.

\section{Downhole log data quality}

Figures F41 and F42 show a summary of the main logging data recorded in Hole U1344A. These data were processed and converted to depth below seafloor and matched to depths between different logging runs. The resulting depth scale is WMSF; see "Downhole measurements" in the "Methods" chapter).

The first indicators of the overall quality of the logs are the size and shape of the borehole measured by the calipers. The hole size measured by the HLDS caliper during the triple combo run and by the FMS arms is shown in the lefthand columns of Figures F41 and F42, respectively. Both sets of calipers indicate a large hole with an average diameter of $>14$ inches, and the HLDS shows that the hole was particularly large between $\sim 170$ and $270 \mathrm{~m}$ WSF. Deeper in the borehole, small enlargements regularly spaced 
every $~ 9.5 \mathrm{~m}$ indicate where the bit was sitting when a core was recovered. However, all of the calipers show that the tools made at least partial contact with the formation over most of the interval logged, suggesting that the overall quality of the data is good.

Irregular hole size has an effect on measurements that require good contact with the formation, namely density and porosity. The anomalously low density values between 230 and $250 \mathrm{~m}$ WSF, which is within the $100 \mathrm{~m}$ interval with the largest hole size, are probably erroneous, as are most of the neutron porosity measurements in this entire interval.

The quality of the logs can also be assessed by comparing them with core measurements made at the same site or by the repeatability of measurements acquired in different runs. Figure F41 shows a comparison of the gamma ray and density logs with the NGR and GRA track data and the MAD measurements made on cores recovered from Hole U1344A. The trends in gamma radiation are very similar between the track and log data, and the lower log gamma ray readings between 170 and 270 mbsf are likely a consequence of the large hole diameter rather than a change in lithology. Considering the scatter inherent in the GRA track measurements, the density log should be compared with the upper envelope of the GRA data. Except for two short intervals with lower density logging data (230-250 m WMSF and 420$430 \mathrm{~m}$ WSF), all density data sets are in good agreement, confirming good data quality overall despite the enlarged hole. Comparison of the gamma ray logs measured during the main passes of the two runs (Fig. F42) shows excellent repeatability between the two runs. All logs were referenced to the seafloor depth of $3184.5 \mathrm{~m}$ WRF identified during the main pass of the triple combo tool string.

The resistivity values measured by the electrode spherically focused resistivity (SFLU) measurement were lower than those recorded by induction measurements (e.g., medium induction phasor-processed resistivity [IMPH] and deep induction phasor-processed resistivity [IDPH] in Fig. F41), probably because of current loss at the electrodes and eccentralization of the sonde. The higher induction resistivity values are more representative of the resistivity of the formation, but the higher resolution SFLU data are a good indication of the finer scale variability in the formation.

The display in Figure F42 of the high coherence in sonic waveforms used to derive the compressional and shear velocities suggests that despite the enlarged hole and the closeness of the formation $V_{\mathrm{P}}$ to the sound velocity in the borehole fluid $(\sim 1500 \mathrm{~m} / \mathrm{h})$, the Dipole Sonic Imager (DSI) was able to capture com- pressional and flexural wave arrivals. However, the erratic $V_{\mathrm{P}}$ curve derived during the second pass of the tool string shows that the acquisition algorithm could not consistently differentiate between the two most coherent arrivals. It mistakenly identified the stronger direct fluid wave as the compressional arrival in many places. This will be corrected by a careful reprocessing, which will also likely reduce the variability of $V_{\mathrm{P}}$ and $V_{\mathrm{S}}$ in some intervals. However, the $V_{\mathrm{P}}$ profile that was routinely recorded while the tool was being lowered provided a more robust $V_{\mathrm{p}}$ profile for preliminary interpretation and will be used in the following discussion.

\section{Logging stratigraphy and correlation}

The combined analysis of the gamma ray, resistivity, density, and velocity logs allows for the identification of several logging units defined by characteristic trends. Because of the uniformity of the sediments at this site (see "Lithostratigraphy"), these units are mostly defined by subtle changes in trends and correlations rather than indications of significant changes in the formation. Because the $V_{\mathrm{p}} \log$ also allows correlation with seismic stratigraphy, it was the primary guide in the delineation of the units. The variations in the content of the three radioactive elements contributing to the natural radioactivity of the formation (K, U, and Th; Fig. F43) were also used for the characterization of these units.

Logging Unit 1 (100-330 m WMSF) is characterized mainly by a steady increase with depth in $V_{\mathrm{P}}$ and $V_{\mathrm{S}}$, whereas the other logging data remain mostly uniform despite some variability, such as in gamma radiation. The bottom of this unit is defined by a noticeable drop in $V_{\mathrm{P}}, V_{\mathrm{S}}$, gamma radiation, density, and resistivity immediately above a sharp peak in these measurements, particularly in $V_{\mathrm{S}}$ and resistivity, indicating a fine stiff layer. This sequence corresponds to a core with poor recovery (Core 323U1344A-35X). The low gamma radiation suggests a more sandy layer, which is often prone to poor recovery. The fine hard layer does not seem to have been recovered either, because nothing was observed in Core 323-U1344A-36X that would match these readings. Using the preliminary $V_{\mathrm{p}}$ downhole $\log$ and the density log we were able to match this interval with a strong reflector observed at $4.67 \mathrm{~s}$ two-way traveltime (Fig. F44) on seismic Line Stk3-7 (Sakamoto et al., 2005) crossing Site U1344. A section with distinctive black sulfide speckles (Sections 323U1344A-18H-3 and 18H-4), which occur in several places in this unit and are recognizable as black conductive features in the FMS images, is shown in Figure F45A. 
Logging Unit 2 (330-460 $\mathrm{m}$ WMSF) is almost uniquely defined by the $V_{\mathrm{P}}$ and $V_{\mathrm{S}} \log$, both of which increase steadily throughout the unit. Gamma radiation and density also increase with depth in this unit in a more subdued manner. A subtle drop in $V_{\mathrm{P}}$ and $V_{\mathrm{S}}$ at $380 \mathrm{~m}$ WMSF can be correlated in Figure F44 with a reflector at $4.73 \mathrm{~s}$ two-way traveltime, which can be extended updip (to the east; see "Background and objectives") to high amplitudes that have been interpreted as free gas trapped at the bottom of the gas hydrate stability field. As at Site U1343, no conclusive indication from the logs supports the occurrence of gas hydrate. However, slightly higher velocity and resistivity trends and lower dipole waveform amplitudes above the reflector, as well as lower chlorinity values measured on several pore water samples, suggest that some amount of gas hydrate may be present. A layer of authigenic carbonates and fine sand from this unit can be seen in the FMS images in Figure F45B.

The top of logging Unit 3 (460-620 m WMSF) is defined by an inflection in the velocity profiles, which, combined with a decreasing trend in density, generates the strong reflector at $4.83 \mathrm{~s}$ two-way traveltime (Fig. F44). In addition to the density logs, the resistivity and gamma ray logs also follow a slightly decreasing trend with depth in this unit. The variability with depth in gamma radiation and in most logs displays a cyclicity that is more clearly defined than in the upper units. A section (323-U1344A-61X-4) with distinctive white carbonate pebbles that occur in several places in this unit and are recognizable as bright resistive features in the FMS images is shown in Figure F45C.

Finally, the top of logging Unit 4 (620-745 m WMSF) is defined by a sharp increase in $V_{\mathrm{p}}, V_{\mathrm{S}}$, gamma radiation, and density, as well as by a significant change in the trends of all the logs. As in the deepest unit of Site U1343, the gamma ray, potassium, thorium, density, resistivity, $V_{\mathrm{P}}$, and $V_{\mathrm{S}} \operatorname{logs}$ all display a variability with depth of wider amplitude and lower frequency than in the upper units, suggesting a significant change in deposition history and rates. Figure F45D shows FMS images that were recorded over a $3 \mathrm{~m}$ section of the $20 \mathrm{~m}$ interval at the top of logging Unit 4 that was not recovered between $\sim 620$ and $640 \mathrm{~m}$ DSF. The image shows conductive (dark) layers dipping steeply to the north and overlaying more conductive speckles similar to the sulfide speckles observed in several places in the hole.

\section{Temperature measurements}

The third-generation advanced piston corer temperature tool (APCT-3) was successfully deployed three times in Hole U1344A. The measured temperatures range from $4.51^{\circ} \mathrm{C}$ at $47.1 \mathrm{~m} \mathrm{DSF}$ to $9.57^{\circ} \mathrm{C}$ at $142.1 \mathrm{~m}$ DSF and closely fit a linear geothermal gradient of $53.3^{\circ} \mathrm{C} / \mathrm{km}$ (Fig. F46). The temperature at the seafloor was $1.65^{\circ} \mathrm{C}$ based on the average of the measurements at the mudline during all APCT-3 deployments. A simple estimate of the heat flow can be obtained from the product of the geothermal gradient by the average thermal conductivity $(0.911 \mathrm{~W} /[\mathrm{m} \cdot \mathrm{K}]$; see "Physical properties"), which gives a value of $48.5 \mathrm{~mW} / \mathrm{m}^{2}$, within the range of previous measurement in the area (the global heat flow database of the International Heat Flow Commission can be found at www.heatflow.und.edu/index.html).

Considering the variations in thermal conductivity with depth, a more accurate measure of the heat flow in a conductive regime can be given by a "Bullard plot." The thermal resistance of an interval is calculated by integrating the inverse of thermal conductivity over depth. If the thermal regime is purely conductive, the heat flow will be the slope of the temperature versus the thermal resistance profiles (Bullard, 1939). The thermal resistance calculated over the intervals overlying the APCT-3 measurements is shown in Table T22, and the resulting linear fit of the temperature gives a slightly lower heat flow value of $48.2 \mathrm{~mW} / \mathrm{m}^{2}$.

\section{References}

Asahi, H., and Takahashi, K., 2007. A 9-year time-series of planktonic foraminifer fluxes and environmental change in the Bering Sea and the central subarctic Pacific Ocean, 1990-1999. Prog. Oceanogr., 72(4):343363. doi:10.1016/j.pocean.2006.03.021

Barron, J.A., and Gladenkov, A.Y., 1995. Early Miocene to Pleistocene diatom stratigraphy of Leg 145. In Rea, D.K., Basov, I.A., Scholl, D.W., and Allan, J.F. (Eds.), Proc. ODP, Sci. Results, 145: College Station, TX (Ocean Drilling Program), 3-19. doi:10.2973/

odp.proc.sr.145.101.1995

Bé, A.W.H., and Tolderlund, D.S., 1971. Distribution and ecology of living planktonic foraminifera in surface waters of the Atlantic and Indian Oceans. In Funnel, B.M., and Riedel, W.R. (Eds.), The Micropaleontology of Oceans: Cambridge (Cambridge Univ. Press), 105-149.

Broecker, W.S., and Peng, T.-H., 1987. The role of $\mathrm{CaCO}_{3}$ compensation in the glacial to interglacial atmospheric $\mathrm{CO}_{2}$ change. Global Biogeochem. Cycles, 1:15-29.

Bubenshchikova, N., Nürnberg, D., Lembke-Jene, L., and Pavlova, G., 2008. Living benthic foraminifera of the Okhotsk Sea: faunal composition, standing stocks and microhabitats. Mar. Micropaleontol., 69(3-4):314-333. doi:10.1016/j.marmicro.2008.09.002

Bujak, J.P., 1984. Cenozoic dinoflagellate cysts and acritarchs from the Bering Sea and northern North Pacific, 
DSDP Leg 19. Micropaleontology, 30(2):180-212. doi:10.2307/1485717

Bullard, E.C., 1939. Heat flow in South Africa. Proc. R. Soc. London, Ser. A, 173:474-502.

Butt, A., 1980. Biostratigraphic and paleoenvironmental analyses of the sediments at the Emperor Seamounts, DSDP Leg 55, Northwestern Pacific: Cenozoic foraminifers. In Jackson, E.D., Koizumi, I., et al., Init. Repts. DSDP, 55: Washington, DC (U.S. Govt. Printing Office), 289325. doi:10.2973/dsdp.proc.55.108.1980

Cooper, A.K., Scholl, D.W., and Marlow, M.S., 1987. Structural framework, sedimentary sequences, and hydrocarbon potential of the Aleutian and Bowers Basins, Bering Sea. In Scholl, D.W., Grantz, A., and Vedder, J. (Eds.), Geology and Resource Potential of the Continental Margin of Western North America and Adjacent Ocean Basins-Beaufort Sea to Baja California (Vol. 6): Earth Sci. Ser. Houston (Circum-Pacific Council for Energy and Mineral Resources), 476-502.

D’Hondt, S.L., Jørgensen, B.B., Miller, D.J., et al., 2003. Proc. ODP, Init. Repts., 201: College Station, TX (Ocean Drilling Program). doi:10.2973/odp.proc.ir.201.2003

Kamikuri, S., Nishi, H., and Motoyama, I., 2007. Effects of late Neogene climatic cooling on North Pacific radiolarian assemblages and oceanographic conditions. Palaeogeogr., Palaeoclimatol., Palaeoecol., 249(3-4):370-392. doi:10.1016/j.palaeo.2007.02.008

Ling, H.Y., 1992. Late Neogene silicoflagellates and ebridians from Leg 128, Sea of Japan. In Pisciotto, K.A., Ingle, J.C., Jr., von Breymann, M.T., and Barron, J., et al. (Eds.), Proc. ODP, Sci. Results, 127/128, Pt. 1: College Station, TX (Ocean Drilling Program), 237-248. doi:10.2973/ odp.proc.sr.127128-1.126.1992

Lisitzin, A.P., 2003. Sea-Ice and Iceberg Sedimentation in the Ocean: Recent and Past: New York (Springer).

Lourens, L.J., Hilgen, F.J., Shackleton, N.J., Laskar, J., and Wilson, D., 2004. The Neogene period. In Gradstein, F.M., Ogg, J.G., and Smith, A.G. (Eds.), A Geological Time Scale 2004. Cambridge (Cambridge Univ. Press), 409440.

Martini, E., 1971. Standard Tertiary and Quaternary calcareous nannoplankton zonation. In Farinacci, A. (Ed.), Proc. 2nd Int. Conf. Planktonic Microfossils Roma: Rome (Ed. Tecnosci.), 2:739-785.

Merrill, R.T., and McElhinny, M.W., 1983. The Earth's Magnetic Field: Its History, Origin, and Planetary Perspective: London (Academic Press).

Normark, W.R., and Carlson, P.R., 2003. Giant submarine canyons: is size any clue to their importance in the rock record? In Chan, M.A., and Archer, A.W. (Eds.), Extreme Depositional Environments: Mega end Members in Geologic Time. Spec. Pap.-Geol. Soc. Am., 370:175-190. doi:10.1130/0-8137-2370-1.175

Okazaki, Y., Takahashi, K., Asahi, H., Katsuki, K., Hori, J., Yasuda, H., Sagawa, Y., and Tokuyama, H., 2005. Productivity changes in the Bering Sea during the late Quaternary. Deep-Sea Res., Part II, 52(16-18):2150-2162. doi:10.1016/j.dsr2.2005.07.003
Peckmann, J., and Thiel, V., 2004. Carbon cycling at ancient methane-seeps. Chem. Geol., 205(3-4):433-467. doi:10.1016/j.chemgeo.2003.12.025

Ramette, A., 2009. Quantitative community fingerprinting methods for estimating the abundance of operational taxonomic units in natural microbial communities. Appl. Environ. Microbiol., 75(8):2495-2505. doi:10.1128/ AEM.02409-08

Reynolds, L., and Thunell, R.C., 1985. Seasonal succession of planktonic foraminifera in the subpolar North Pacific. J. Foraminiferal Res., 15(4):282-301. doi:10.2113/gsjfr.15.4.282

Sakamoto, T., Ikehara, M., Aoki, K., Iijima, K., Kimura, N., Nakatsuka, T., and Wakatsuchi, M., 2005. Ice-rafted debris (IRD)-based sea-ice expansion events during the past 100 kyrs in the Okhotsk Sea. Deep Sea Res., Part II, 52(16-18):2275-2301. doi:10.1016/j.dsr2.2005.08.007

Springer, A.M., McRoy, C.P., and Flint, M.V., 1996. The Bering Sea Green Belt: shelf-edge processes and ecosystem production. Fish. Oceanogr., 5(3-4):205-223. doi:10.1111/j.1365-2419.1996.tb00118.x

Takahashi, K., 2005. The Bering Sea and paleoceanography. Deep-Sea Res., Part II, 52(16-18):2080-2091. doi:10.1016/j.dsr2.2005.08.003

Takahashi, K., Ravelo, A.C., and Alvarez Zarikian, C.A., 2009. Pliocene-Pleistocene paleoceanography and climate history of the Bering Sea. IODP Sci. Prosp., 323. doi:10.2204/iodp.sp.323.2009

Taniguchi, A., 1984. Microzooplankton biomass in the arctic and subarctic Pacific Ocean in summer. In Hoshiai, T., and Fukuchi, M., Proc. Sixth Symp. Polar Biol. Mem. Natl. Inst. Polar Res. Spec. Issue (Jpn.), 32:63-76.

Thierstein, H.R., Geitzenauer, K.R., Molfino, B., and Shackleton, N.J., 1977. Global synchroneity of late Quaternary coccolith datum levels validation by oxygen isotopes. Geology, 5(7):400-404. doi:10.1130/ 0091-7613(1977)5<400:GSOLQC>2.0.CO;2

VanLaningham, S., Pisias, N.G., Duncan, R.A., and Clift, P.D., 2009. Glacial-interglacial sediment transport to the Meiji Drift, northwest Pacific Ocean: evidence for timing of Beringian outwashing. Earth Planet. Sci. Lett., 277(1-2):64-72. doi:10.1016/j.epsl.2008.09.033

Yanagisawa, Y., and Akiba, F., 1998. Refined Neogene diatom biostratigraphy for the northwest Pacific around Japan, with an introduction of code numbers for selected diatom biohorizons. Chishitsugaku Zasshi, 104:395-414.

Zahn, R., Rushdi, A., Pisias, N.G., Bornhold, B.D., Blaise, B., and Karlin, R., 1991. Carbonate deposition and benthic $\delta^{13} \mathrm{C}$ in the subarctic Pacific: implications for changes of the oceanic carbonate system during the past 750,000 years. Earth Planet. Sci. Lett., 103(1-4):116-132. doi:10.1016/0012-821X(91)90154-A

Publication: 15 March 2011 MS 323-108 
Figure F1. Navigation map of Hakuhou-Maru Cruise KH99-3 around Site U1344 for seismic profiles, including close-ups shown in Figures F3 and F4.

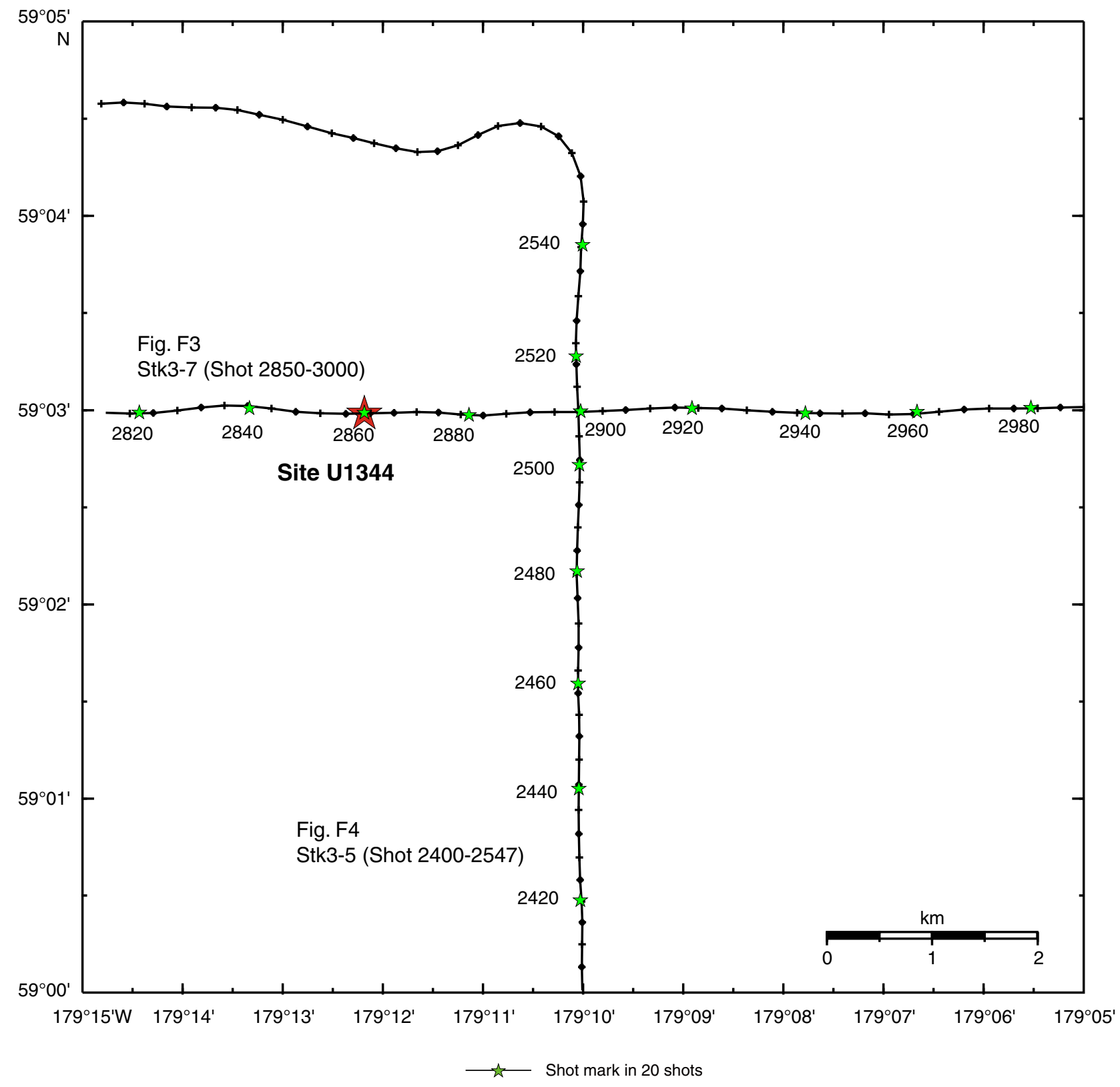


Figure F2. Seismic profile of Hakuhou-Maru Cruise KH99-3 Line Stk3-7 (west-east) with the location of Site U1344 shown. Cross point with Line Stk3-5 (south-north) is at Shotpoint 2510.

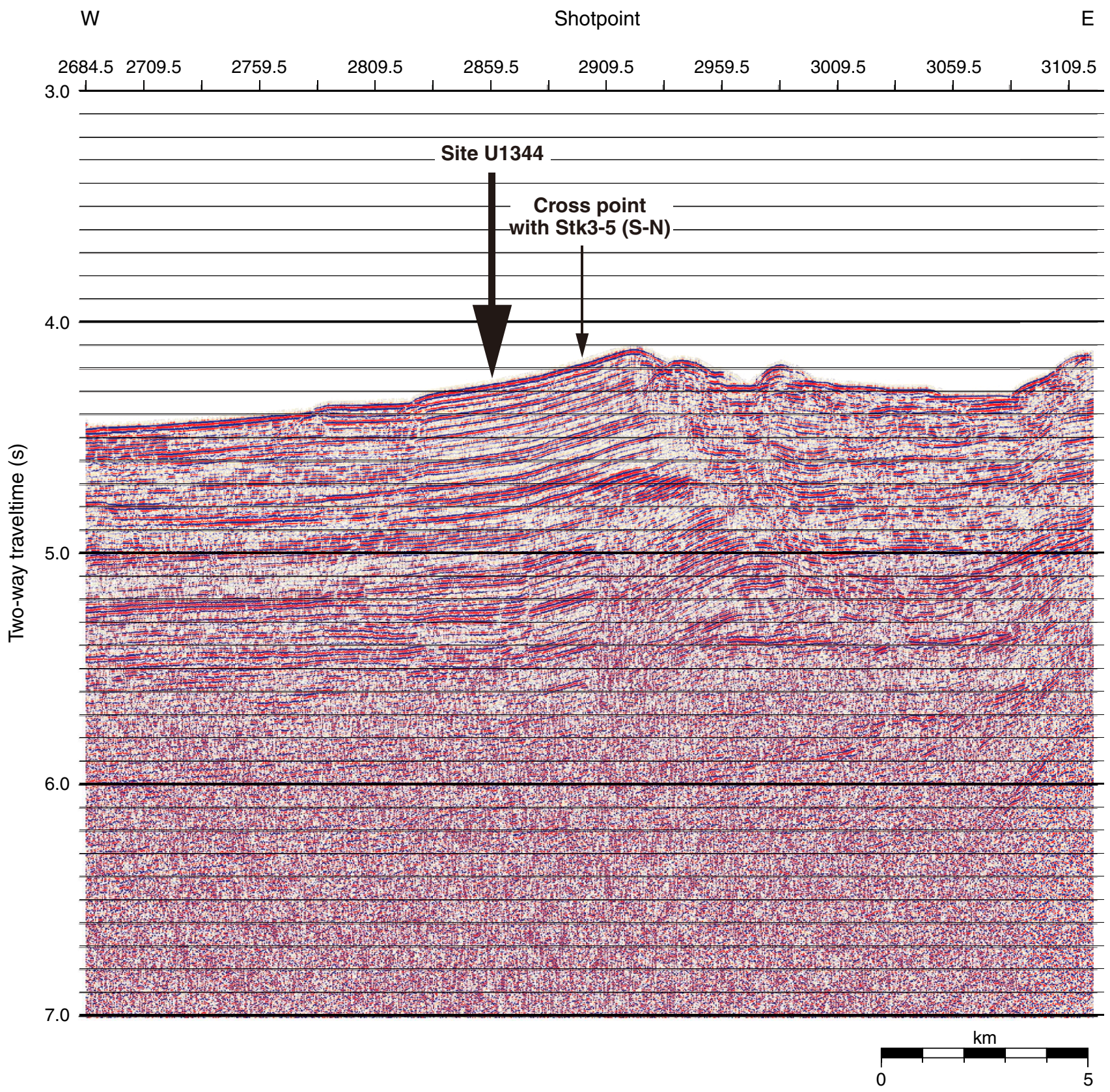


Figure F3. A. Close-up seismic profile of Hakuhou-Maru Cruise KH99-3 Line Stk3-7 (west-east) near Site U1344. B. Time-depth curve estimated from results of velocity analyses on Lines Stk3-7 and Stk3-5 around Site U1344.

A W Shotpoint

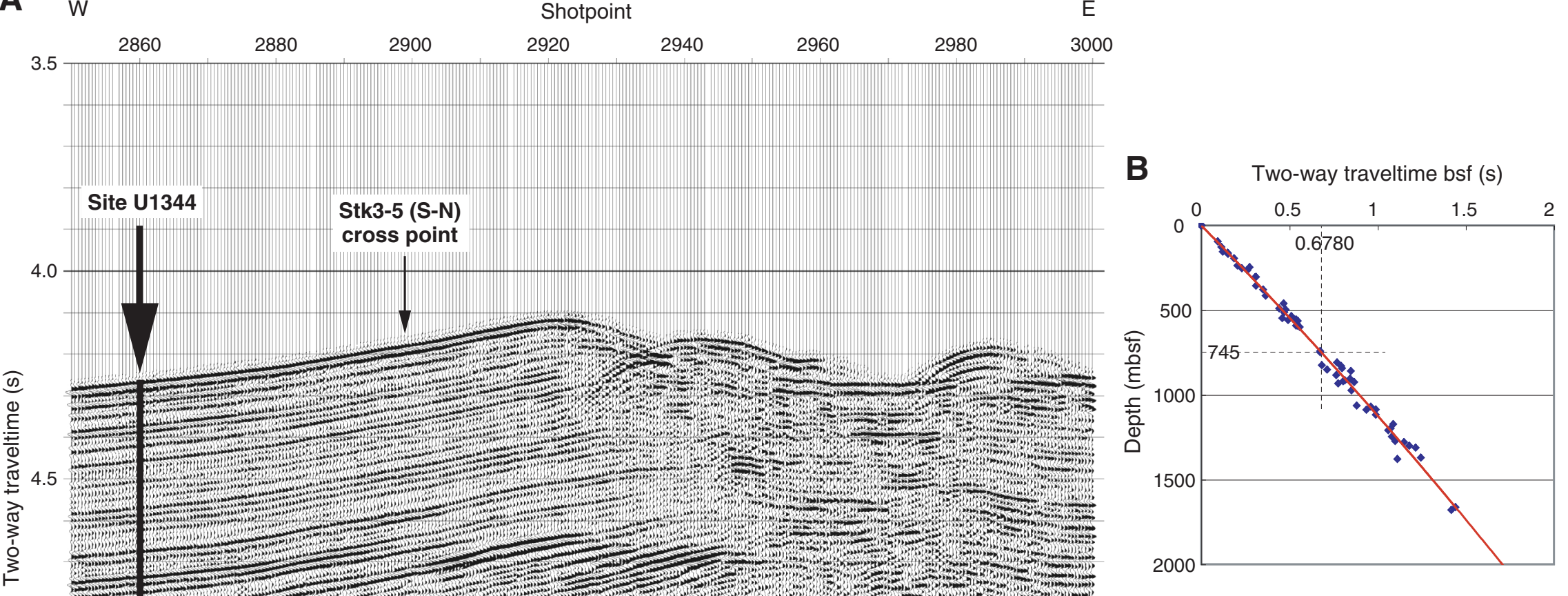

5.0

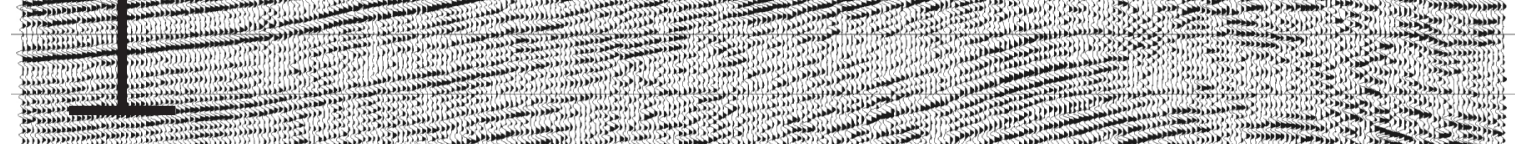

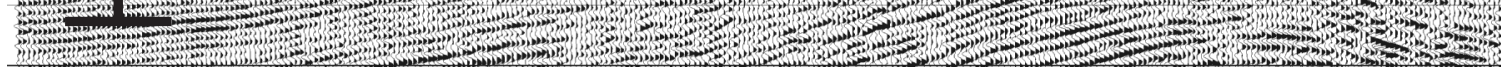

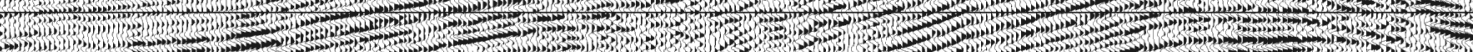

Antr.

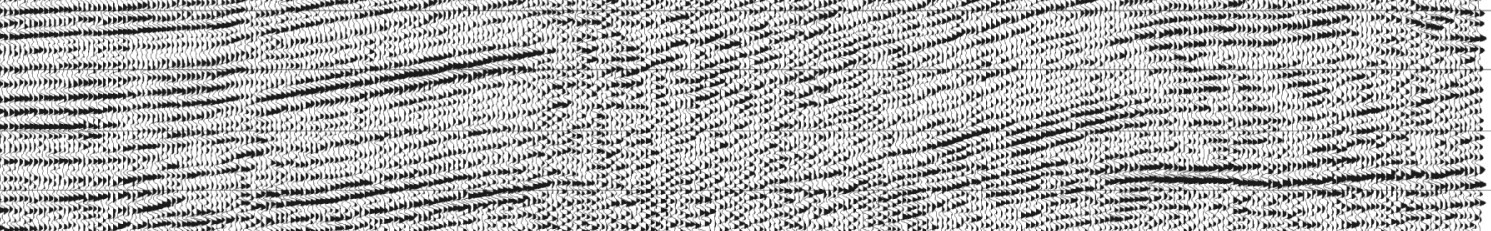

S.M.

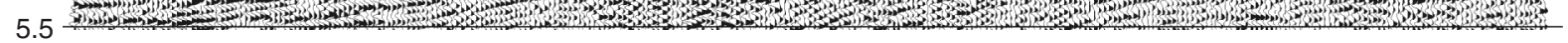

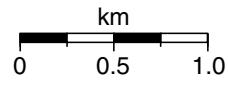


Figure F4. A. Close-up seismic profile of Hakuhou-Maru Cruise KH99-3 Line Stk3-5 (south-north) near Site U1344. The drill penetration of Site U1344 is shown by the dashed line. Cross point with Stk3-7 (west-east) is at Shotpoint 2900. B. Time-depth curve estimated from results of velocity analyses on Lines Stk3-7 and Stk3-5 around Site U1344.

A

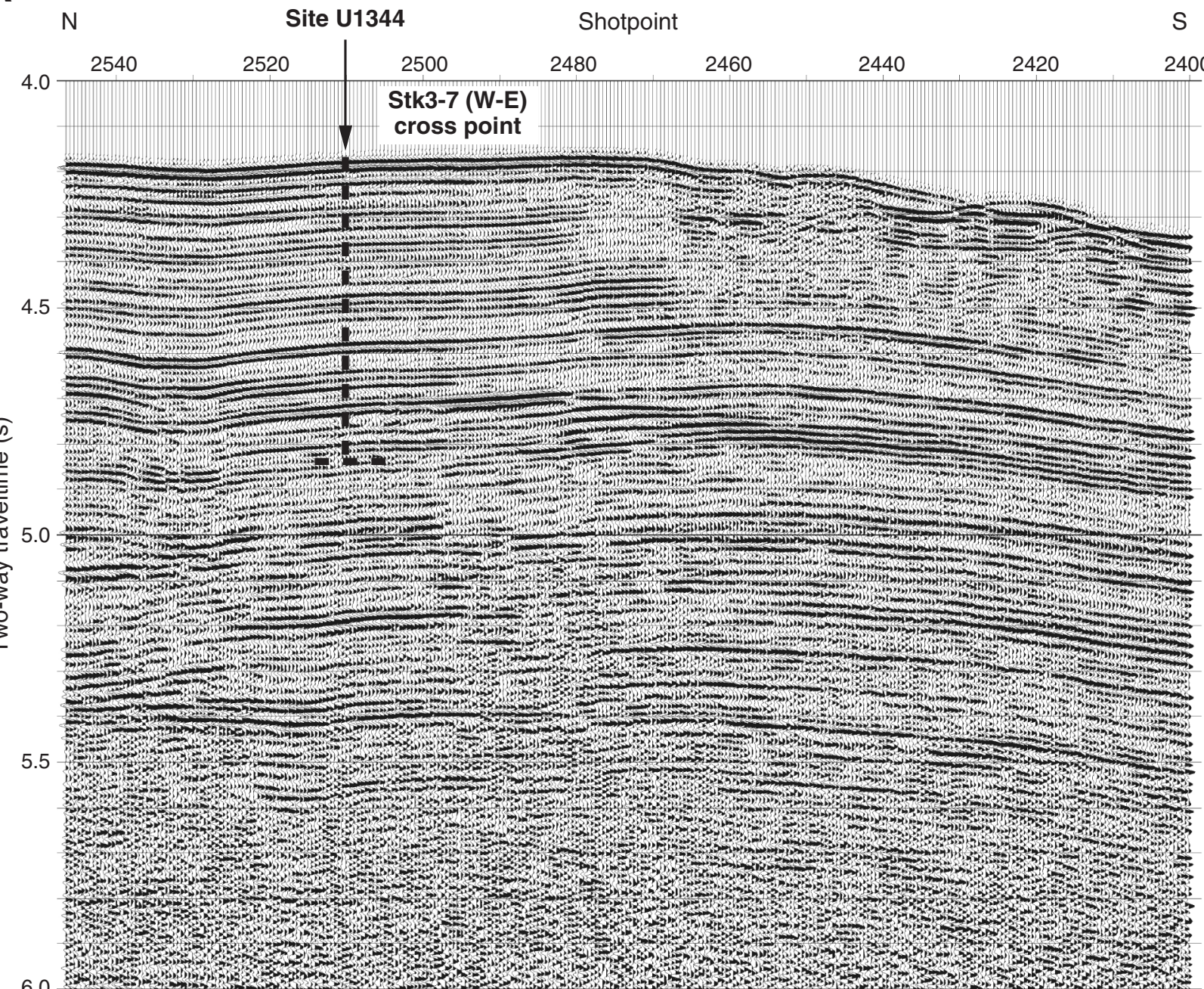

B Two-way traveltime bsf (s)

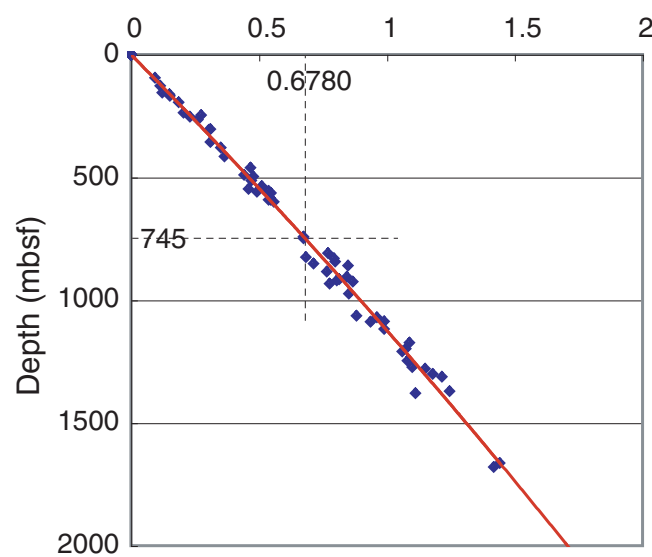

0.0

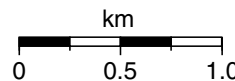


Figure F5. Location map for Site U1344, on a topographic high on the Bering Sea shelf.

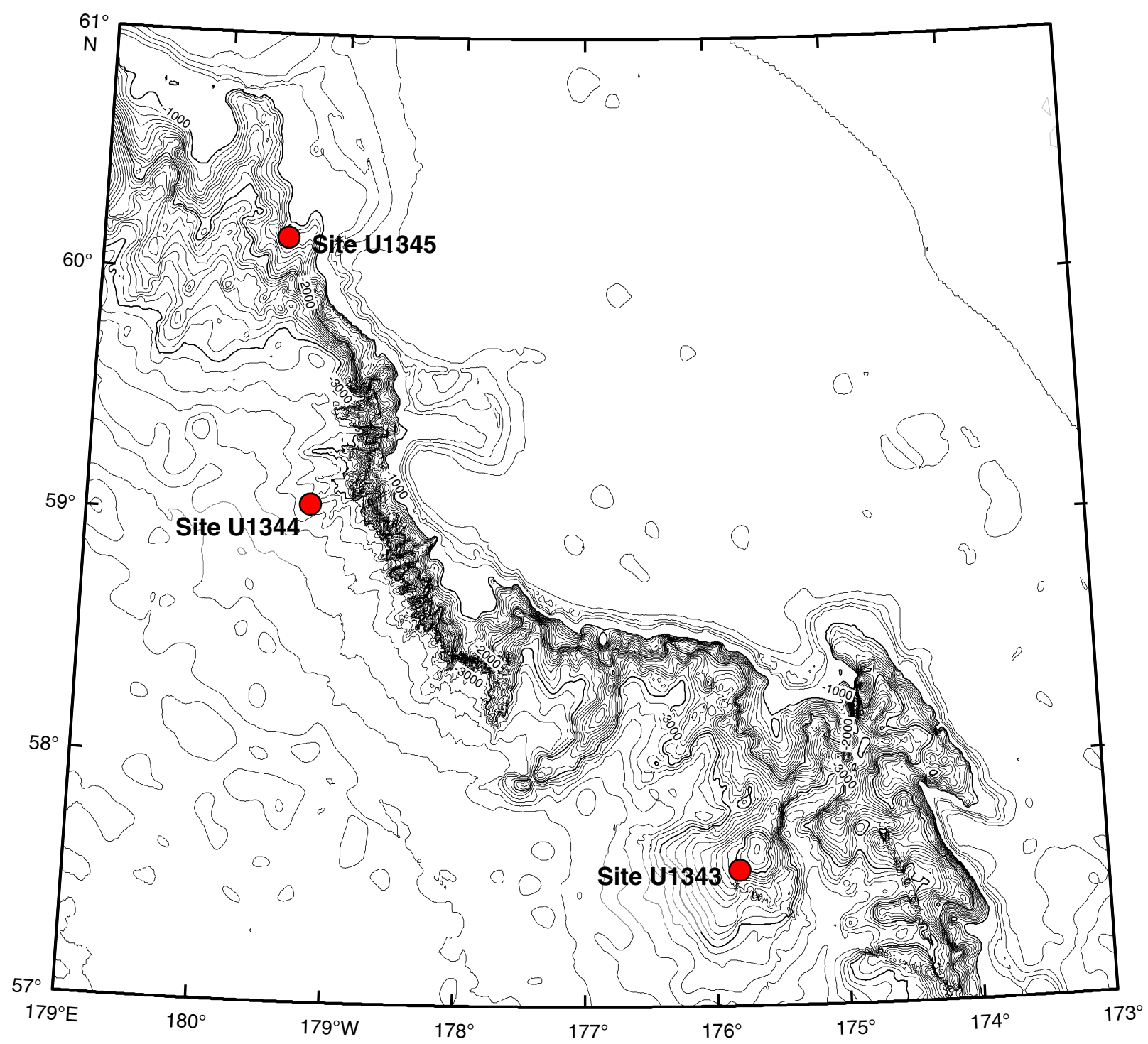


Figure F6. Summary of lithology, structures, accessories, microfossils, and physical properties, Hole U1344A. See legend in Figure F6 in the "Methods" chapter. Soft-sed = soft-sediment, auth = authigenic, calc = calcareous, NGR = natural gamma radiation, GRA = gamma ray attenuation, sed rate $=$ sedimentation rate. A. $0-250$ mbsf. (Continued on next two pages.)

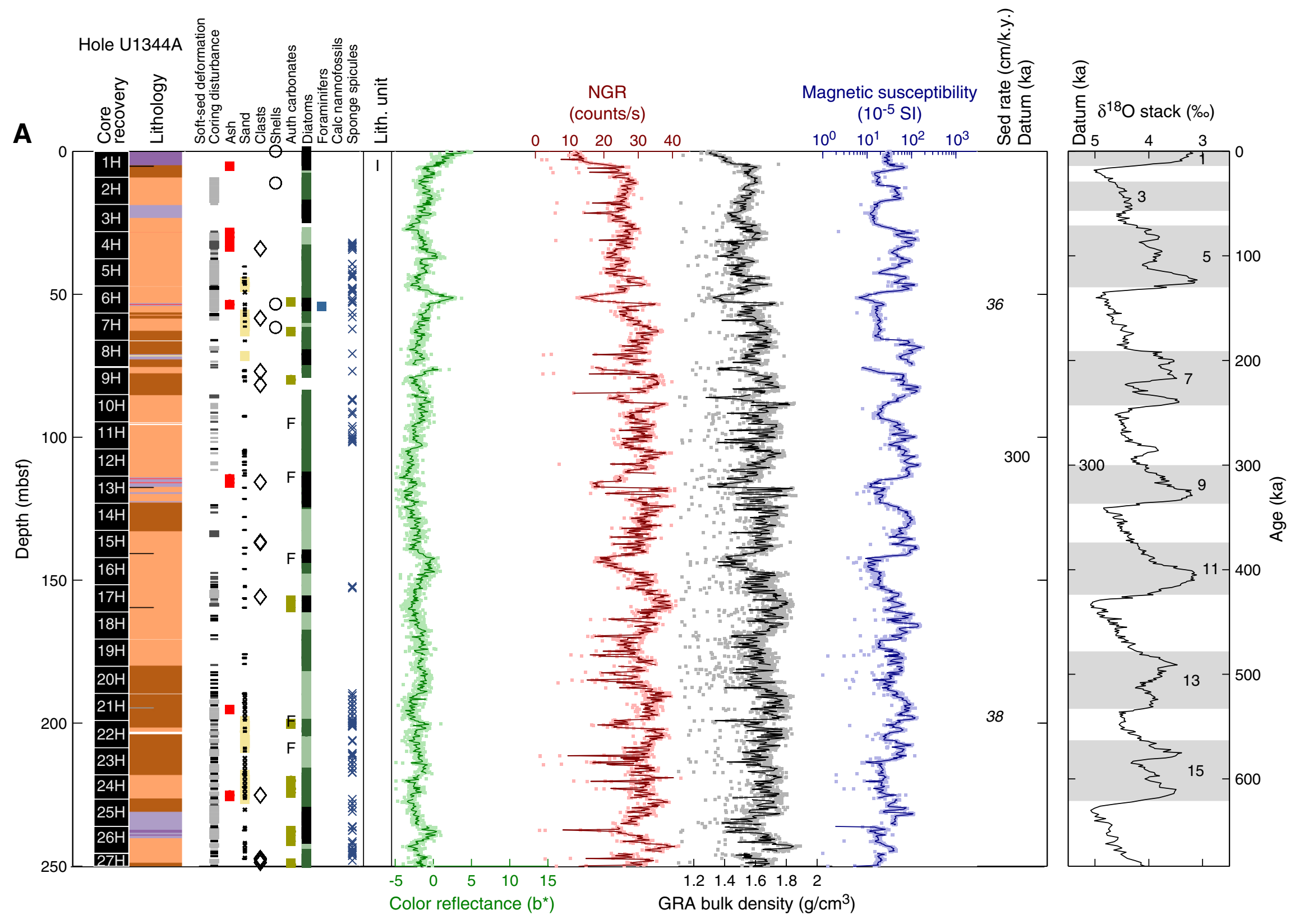


Figure F6 (continued). B. 250-500 mbsf. (Continued on next page.)

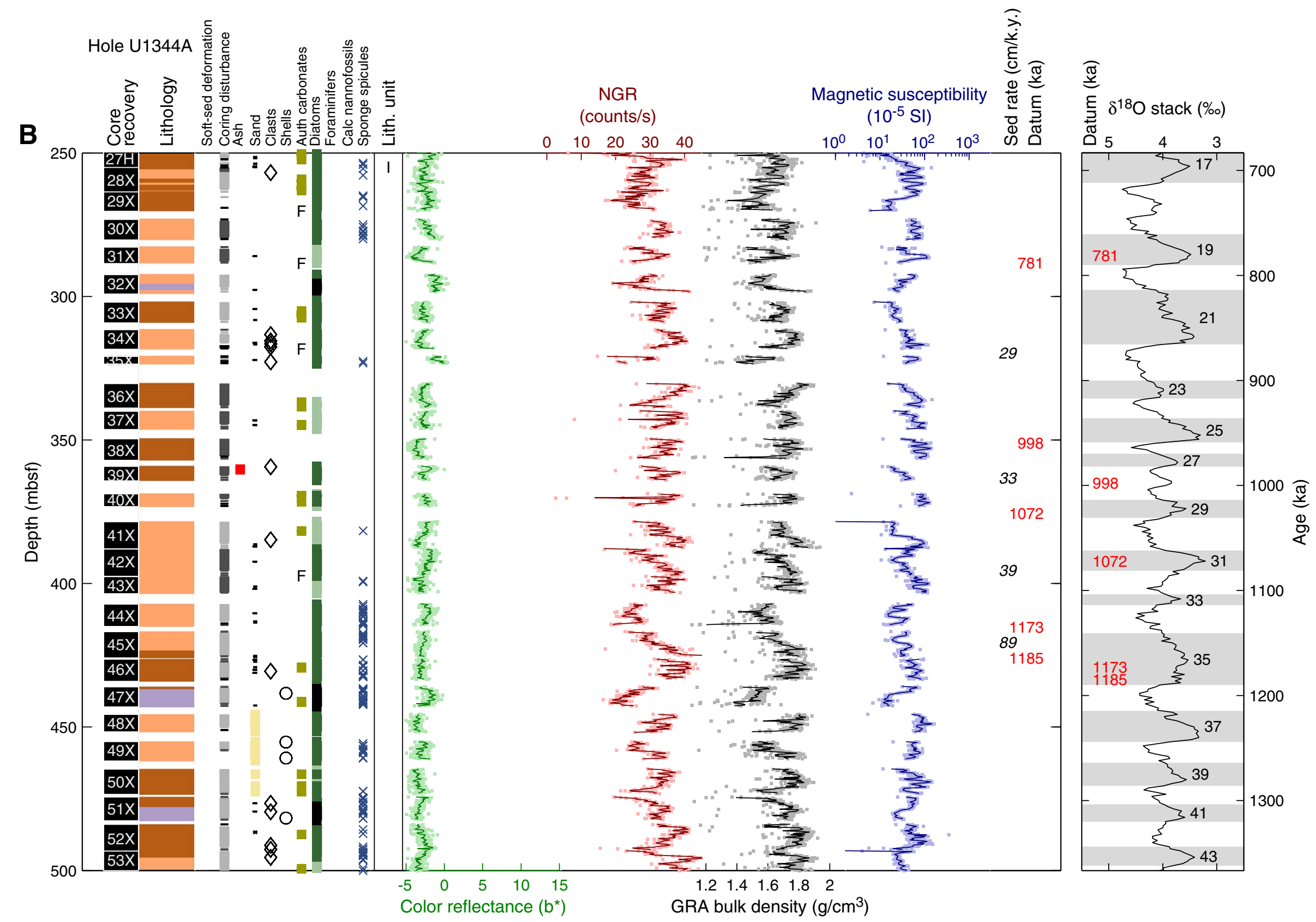


Figure F6 (continued). C. 500-750 mbsf.

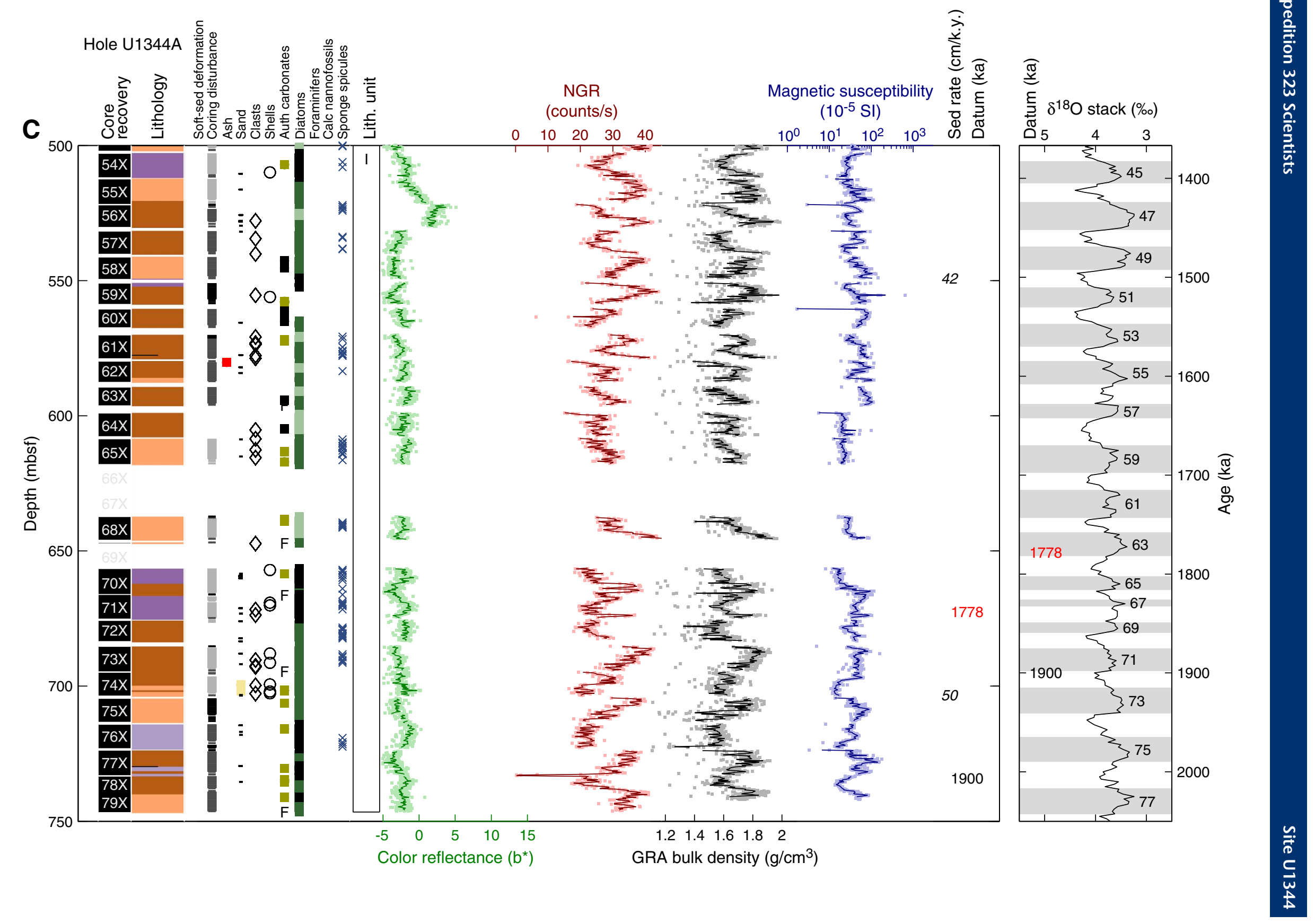


Figure F7. Summary of lithology, structures, accessories, microfossils, and physical properties, Hole U1344D. See legend in Figure F6 in the "Methods" chapter. Soft-sed = soft-sediment, auth = authigenic, calc = calcareous, NGR = natural gamma radiation, GRA = gamma ray attenuation, sed rate $=$ sedimentation rate. A. $0-250$ mbsf. (Continued on next page.)
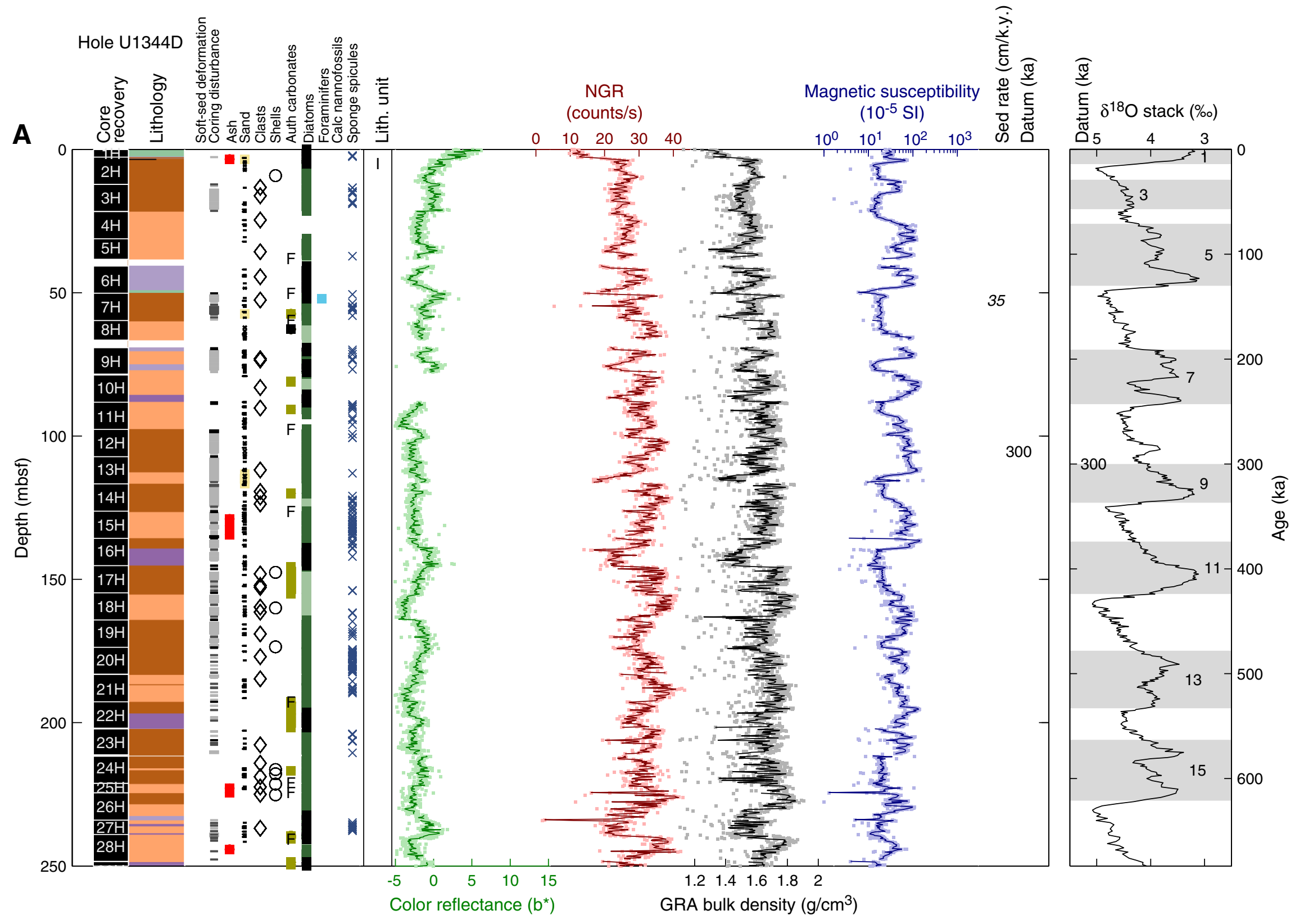


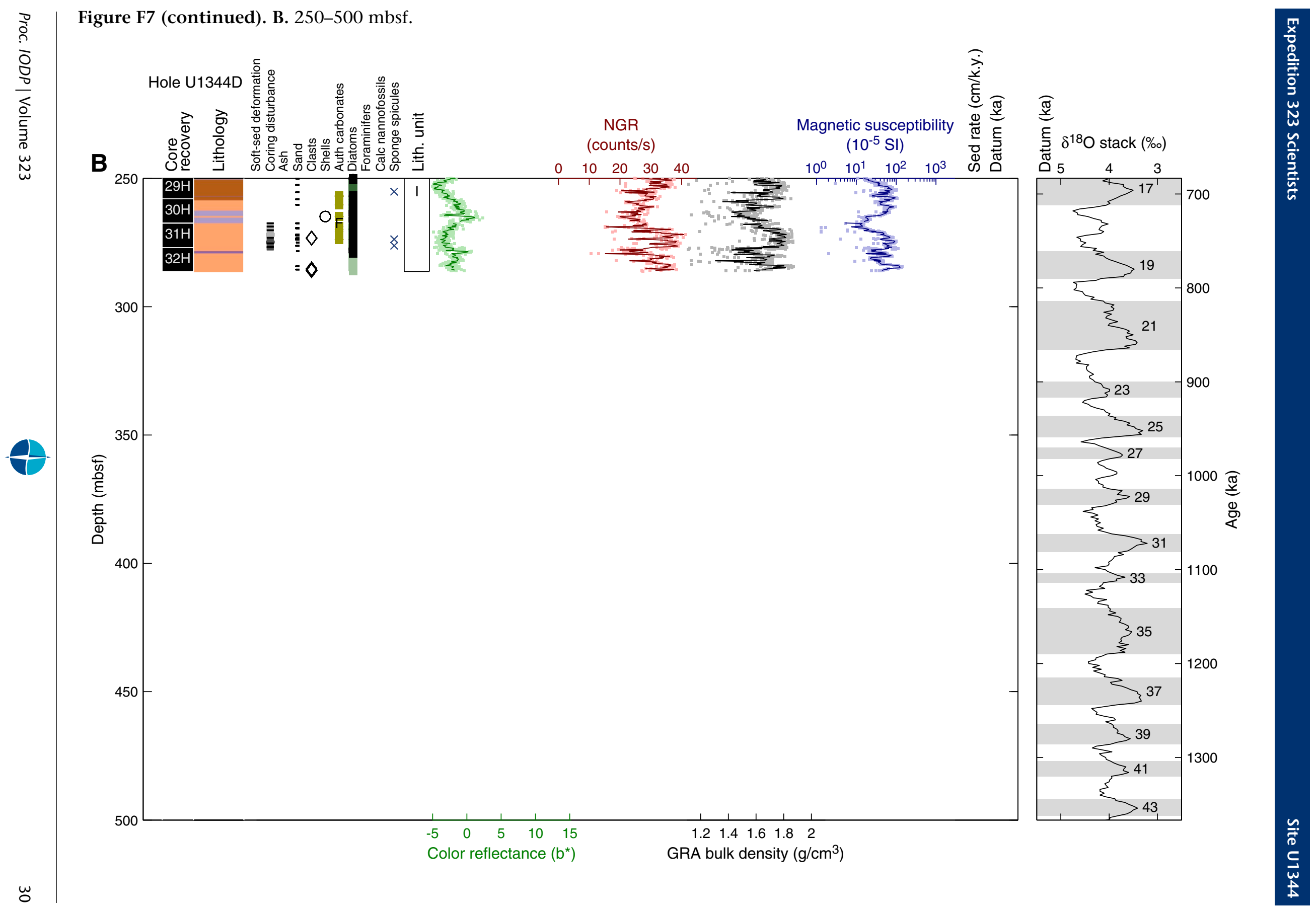


Figure F8. Summary of lithology, structures, accessories, microfossils, and physical properties, Hole U1344E. See legend in Figure F6 in the "Methods" chapter. Soft-sed = soft-sediment, auth = authigenic, calc = calcareous, NGR = natural gamma radiation, GRA = gamma ray attenuation, sed rate $=$ sedimentation rate.

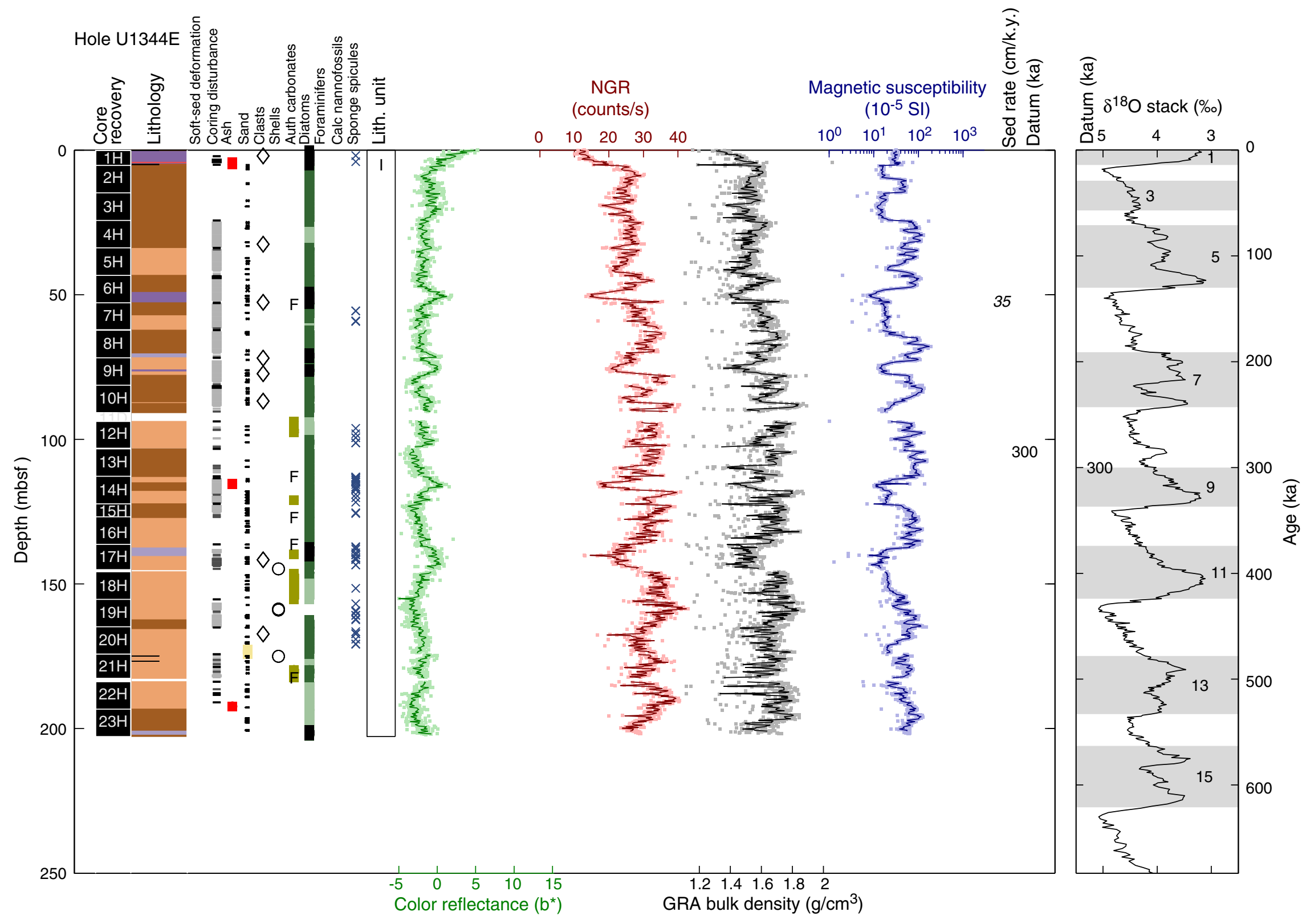


Figure F9. Photograph of core piece from Section 323-U1344A-73X-CC showing a $9 \mathrm{~mm}$ long sponge spicule aggregate.

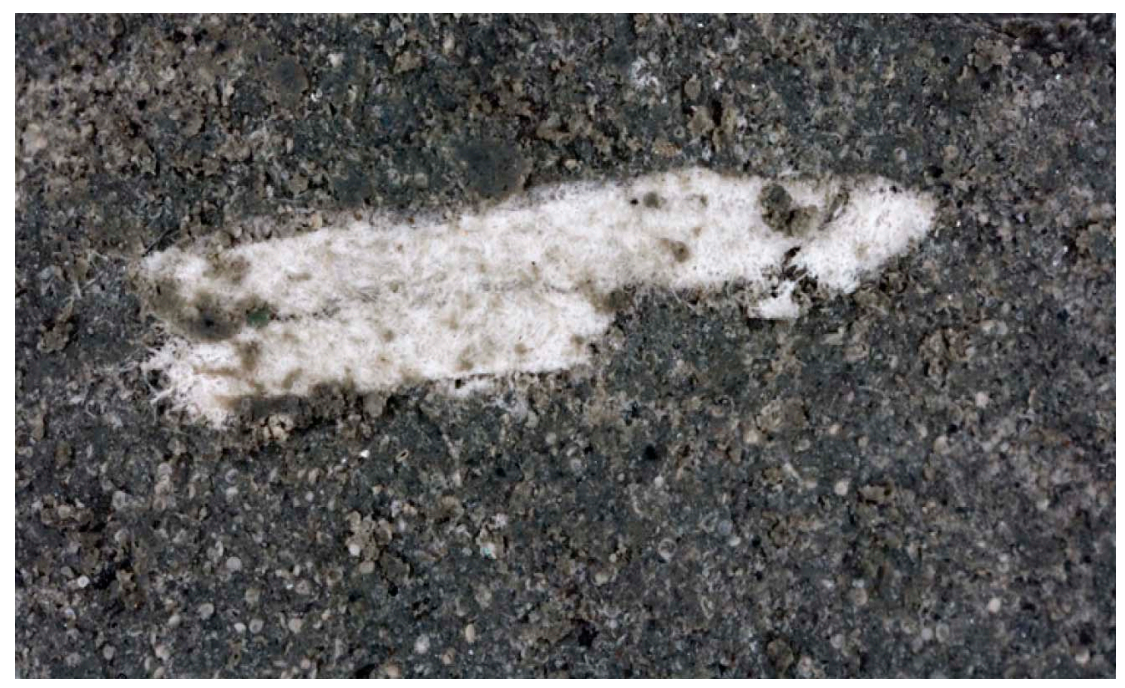


Figure F10. Photograph of core sample from Section 323-U1344D-19H-3, $150 \mathrm{~cm}$, showing an exceptionally well-preserved bivalve shell.

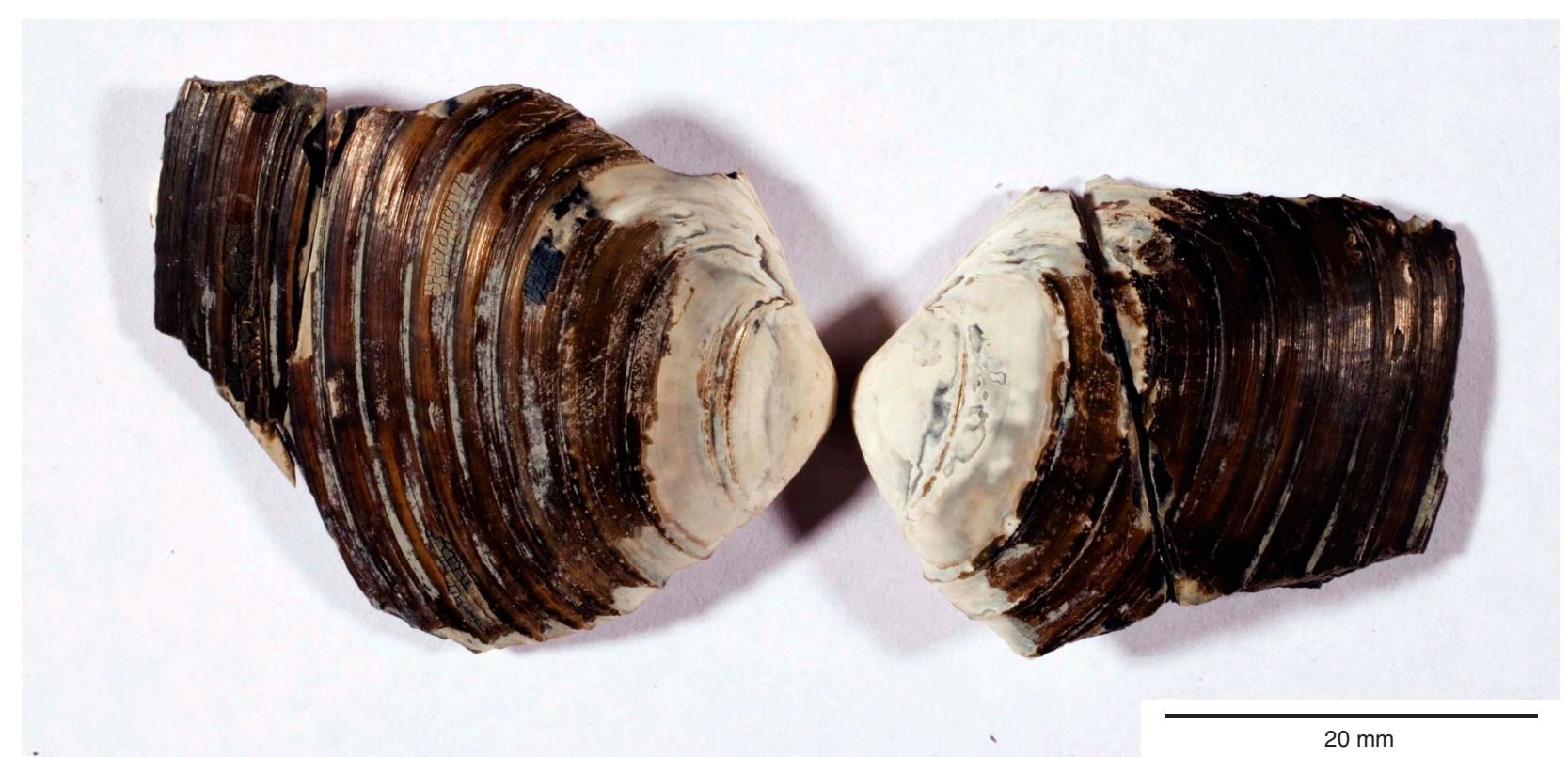


Figure F11. Core photograph of laminated diatom ooze intervals. A. Interval 323-U1344A-1H-4, 72-84.5 cm (5.3 mbsf). B. Interval 323-U1344D-2H-1, 76-88 cm (3.5 mbsf).
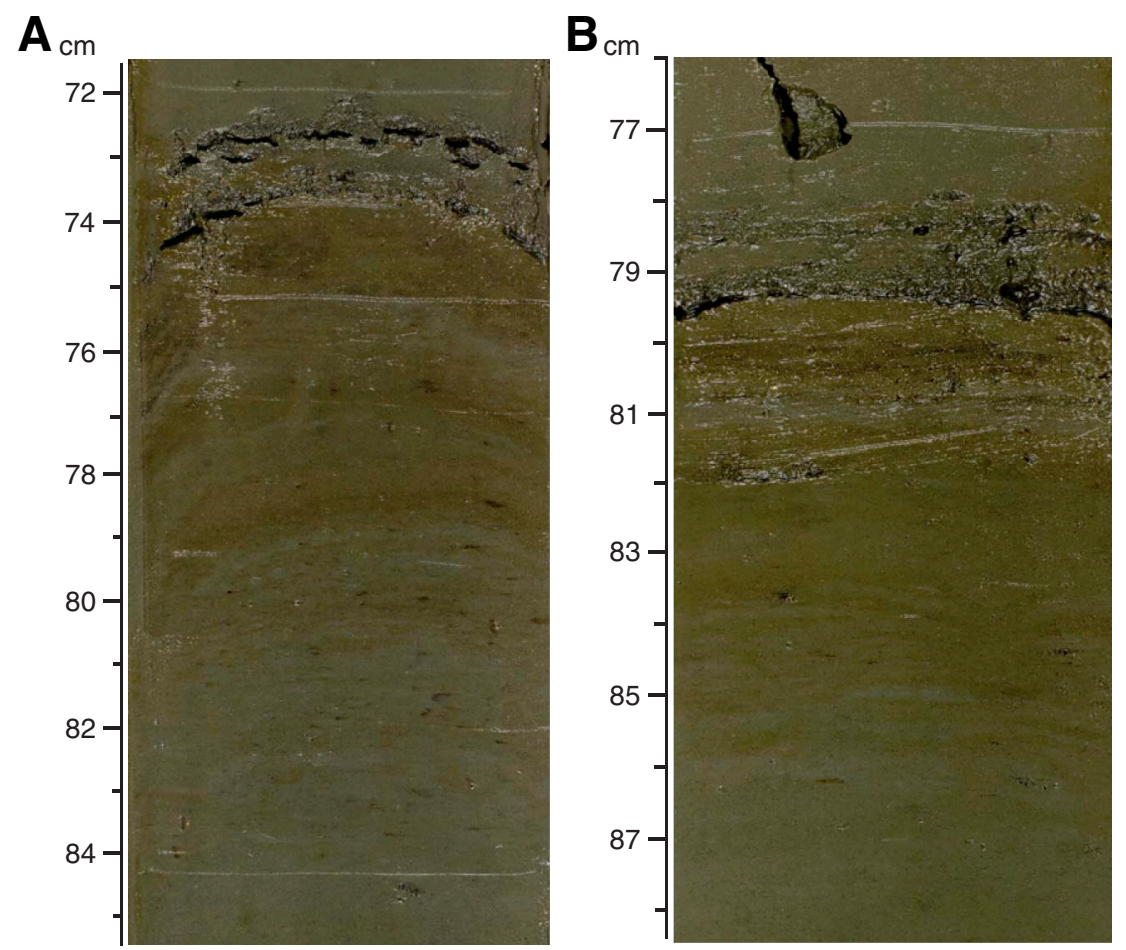
Figure F12. Core photograph from interval 323-U1344A-16H-4, 38-49 cm, showing a sandy layer with a sharp, slightly bioturbated base and sharp top. Beneath the sandy layer are sandy mottles, where material was transported downcore by bioturbation.

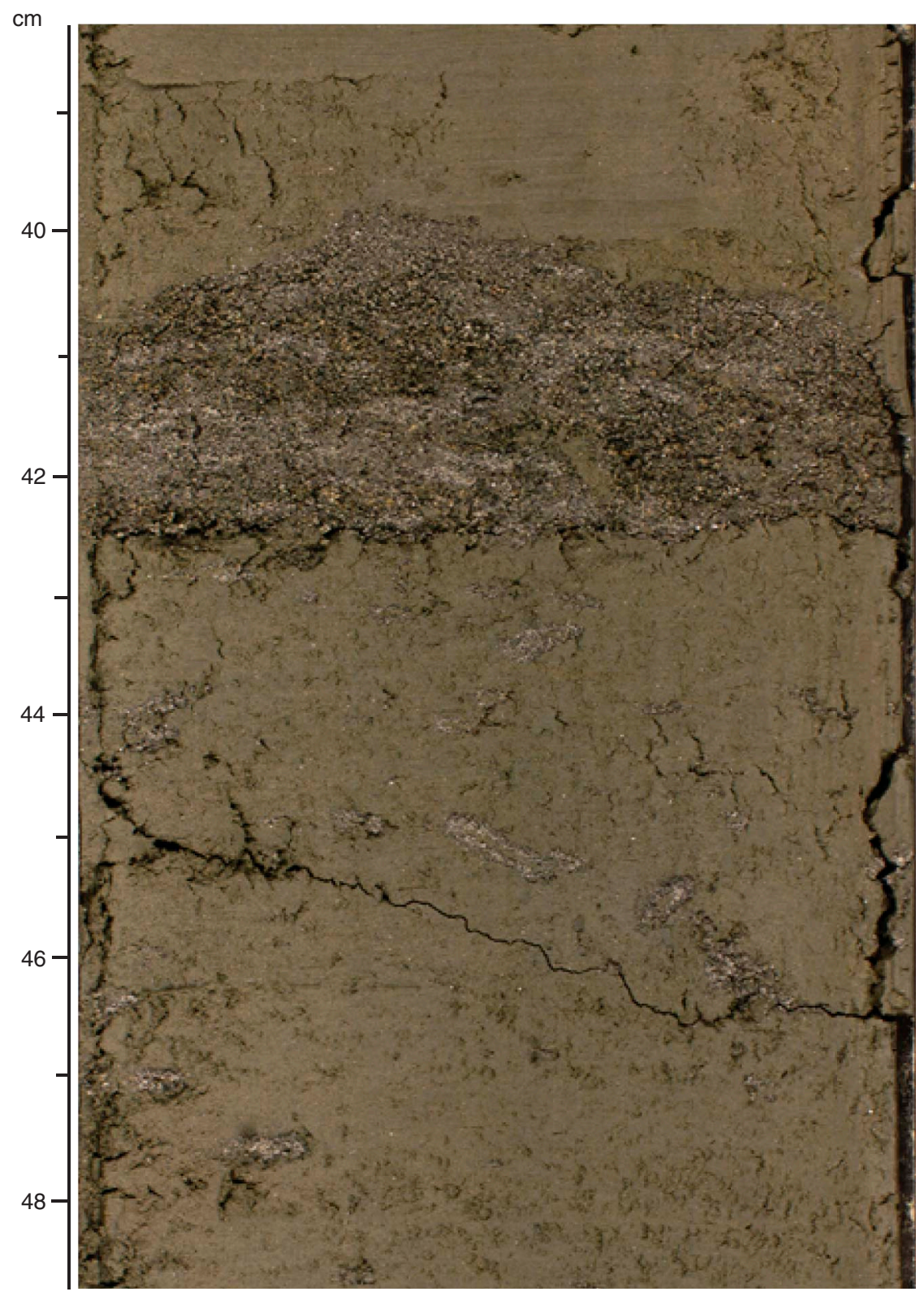


Figure F13. Core photographs showing a range of gravel-sized clasts. A. Plutonic rock (interval 323-U1344A69X-CC, 35-44 cm). B. Basalt (interval 323-U1344A-61X-CC, 14-17.5 cm). C. Quartzite (interval 323-U1344A$65 \mathrm{X}-3,110.5-115 \mathrm{~cm})$.

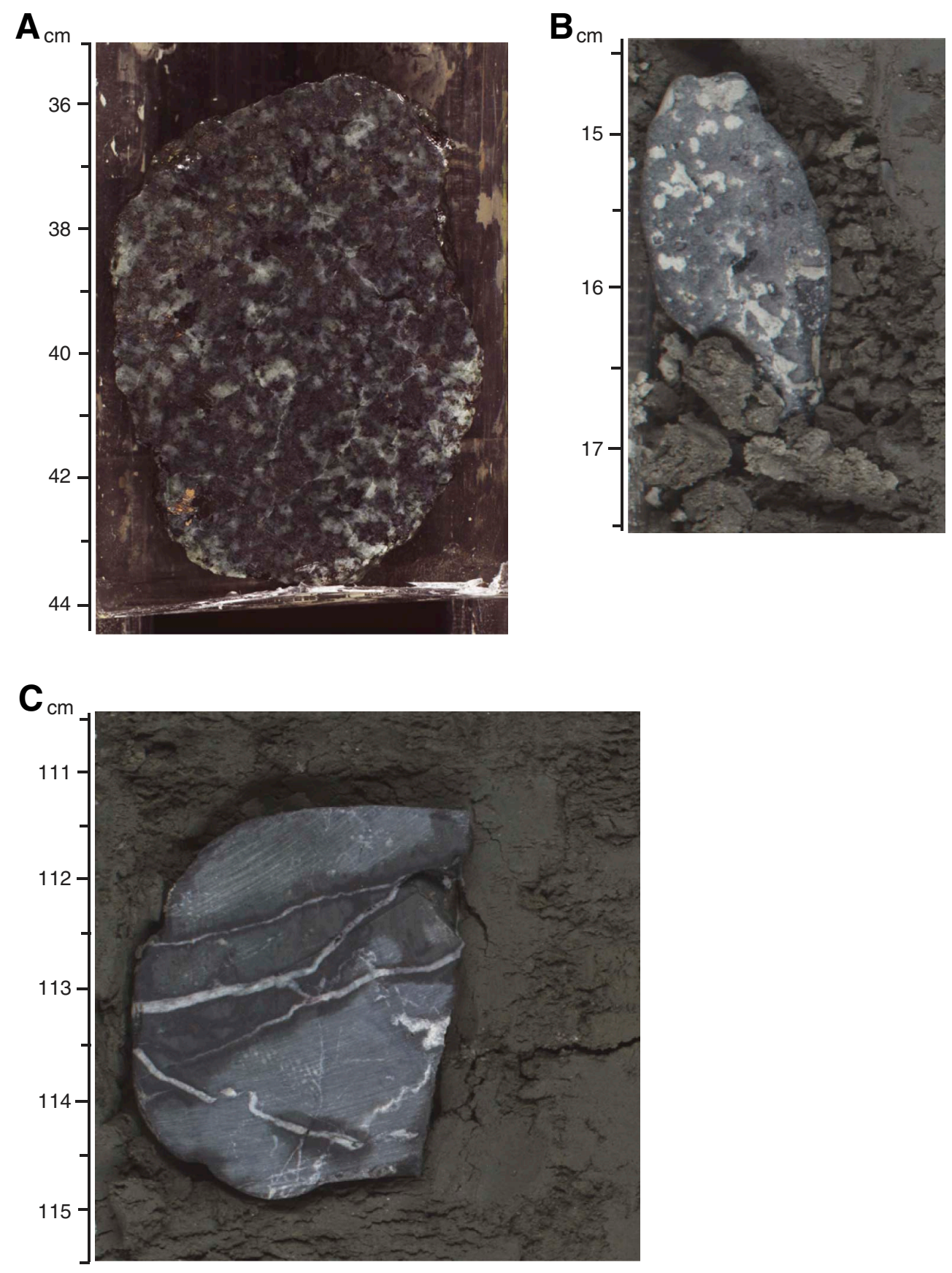


Figure F14. Core photograph from interval 323-U1344D-15H-5, 37-47 cm, showing a light colored ash layer with a sharp, slightly bioturbated base and gradational, bioturbated top.

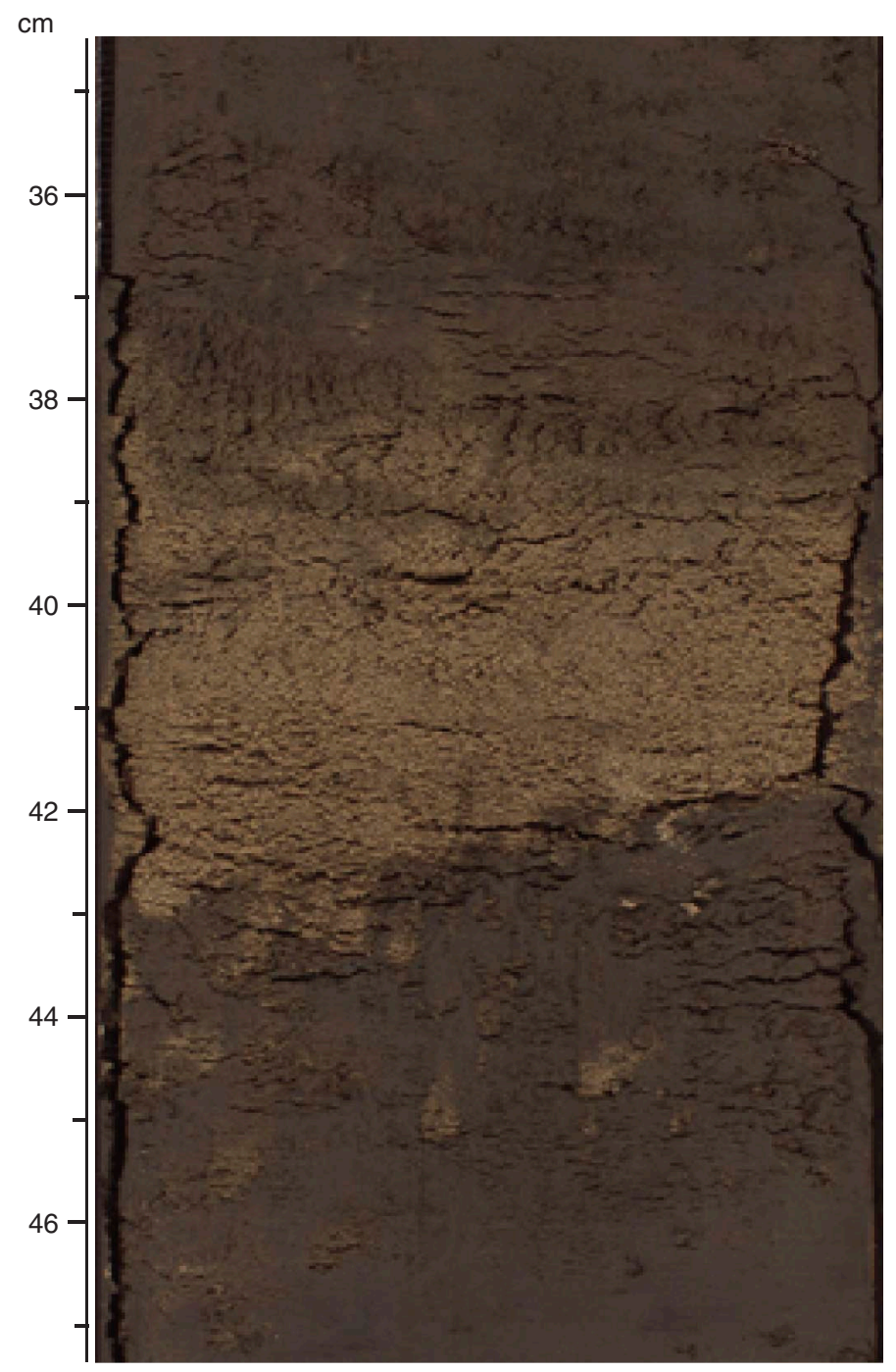


Figure F15. Core photograph from interval 323-U1344A-65X-4, 25-37 cm, showing yellow mottles, which indicate the presence of authigenic carbonate.

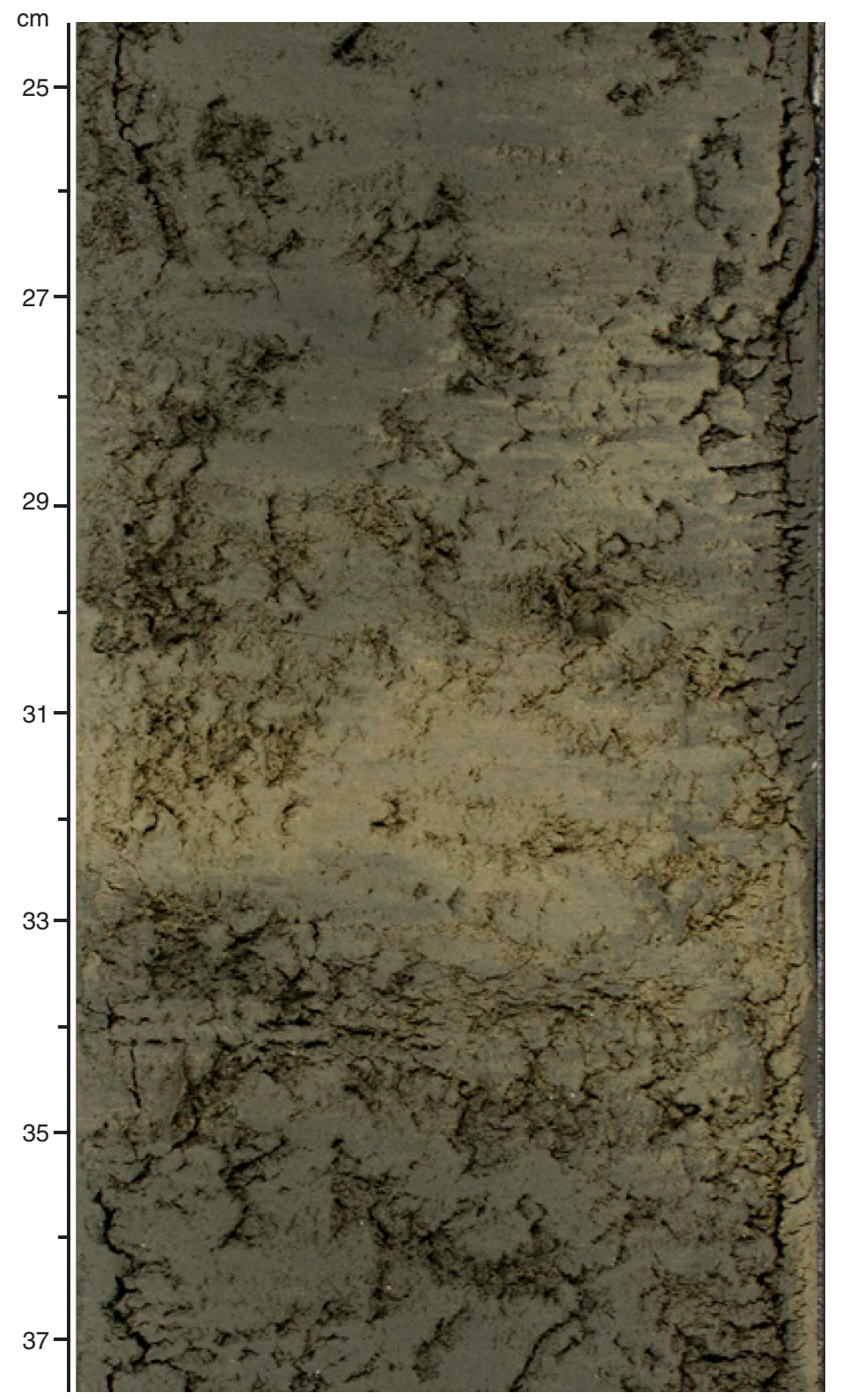


Figure F16. Age-depth plot for Site U1344 showing biostratigraphic datums based on radiolarians, diatoms, silicoflagellates, ebridians, and dinoflagellates. Biostratigraphic datums are listed in Table T2.

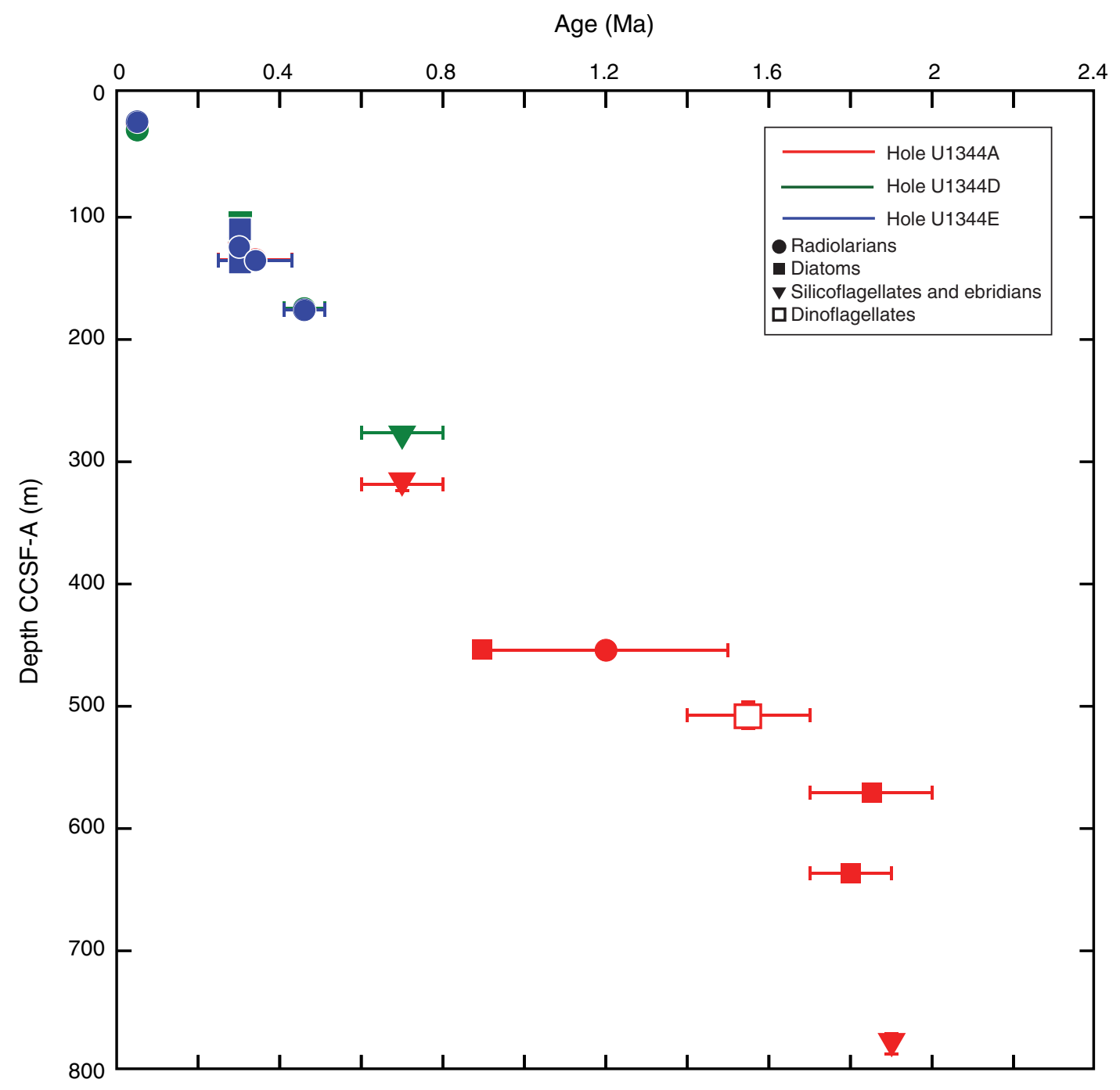


Figure F17. Different abundance estimations for all major groups of fossils. Sea ice diatoms considered include Thalassiosira antarctica spores, Bacteriosira fragilis, Thalassiosira hyaline, Fragilariopsis cylindrus, and Detonula confervacea. For foraminifer abundance estimations, see "Biostratigraphy" in the "Methods" chapter. $\mathrm{B}=$ barren, $\mathrm{P}=$ present, $\mathrm{R}=$ rare, $\mathrm{F}=\mathrm{few}, \mathrm{C}=$ common, $\mathrm{A}=$ abundant, $\mathrm{D}=$ dominant.

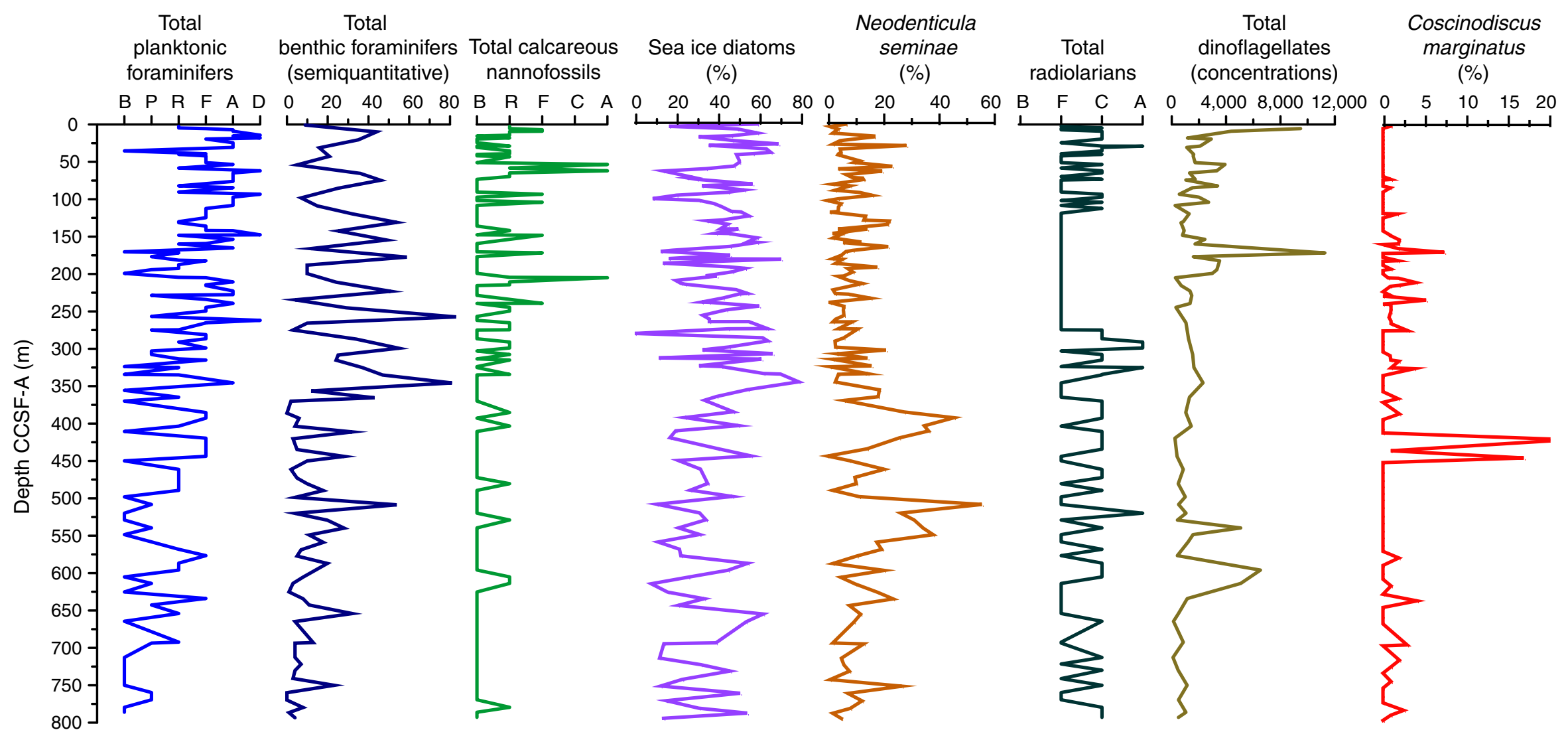


Figure F18. Estimations of relative abundances of different benthic foraminifer taxa, Hole U1344A. For foraminifer abundance estimations, see "Biostratigraphy" in the "Methods" chapter.

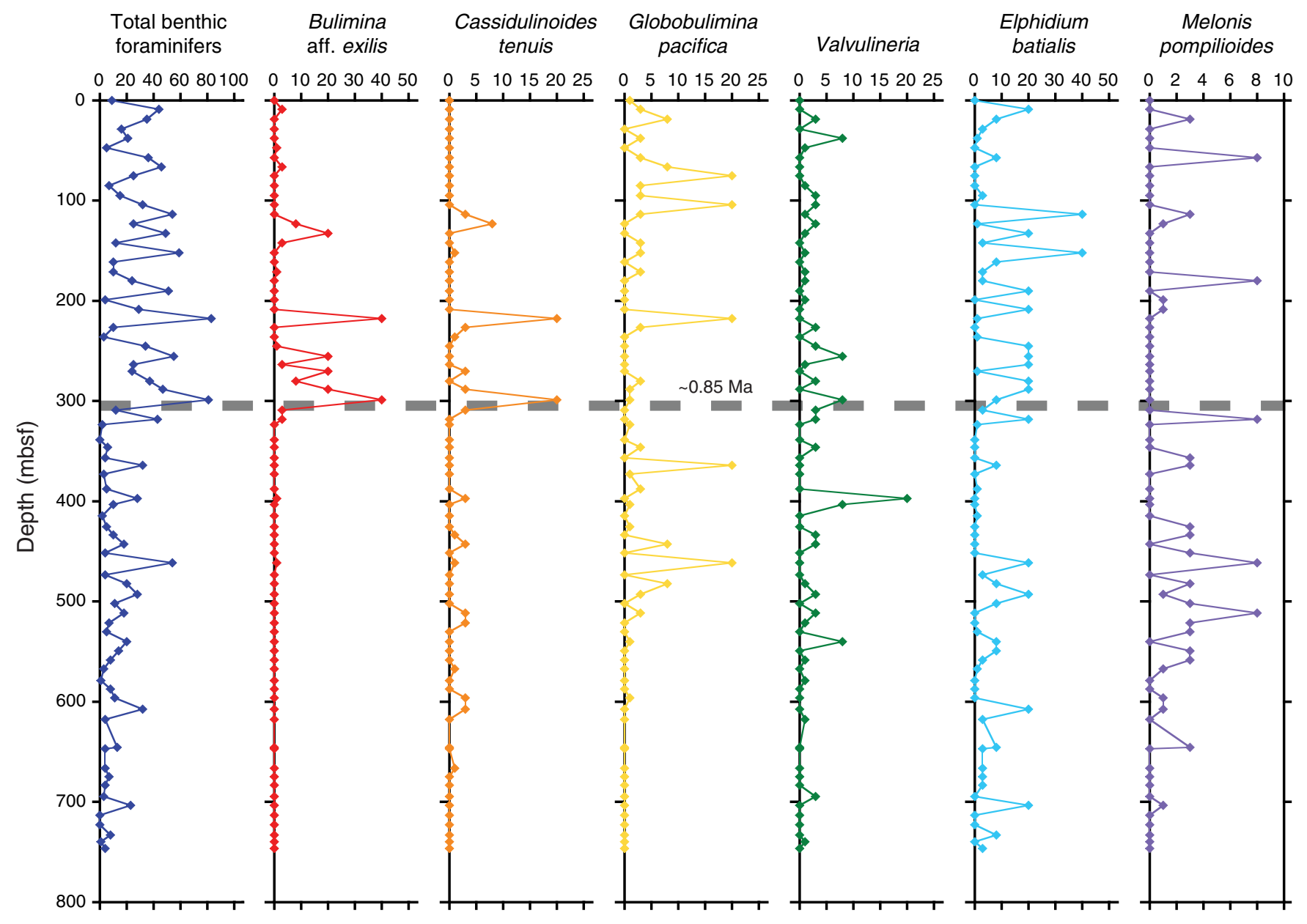


Figure F19. Comparison of the abundance of benthic foraminifers and Bulimina aff. exilis (a low-oxygen indicator) between Sites U1343 and U1344. For foraminifer abundance estimations, see "Biostratigraphy" in the "Methods" chapter.

Site U1343

Site U1344

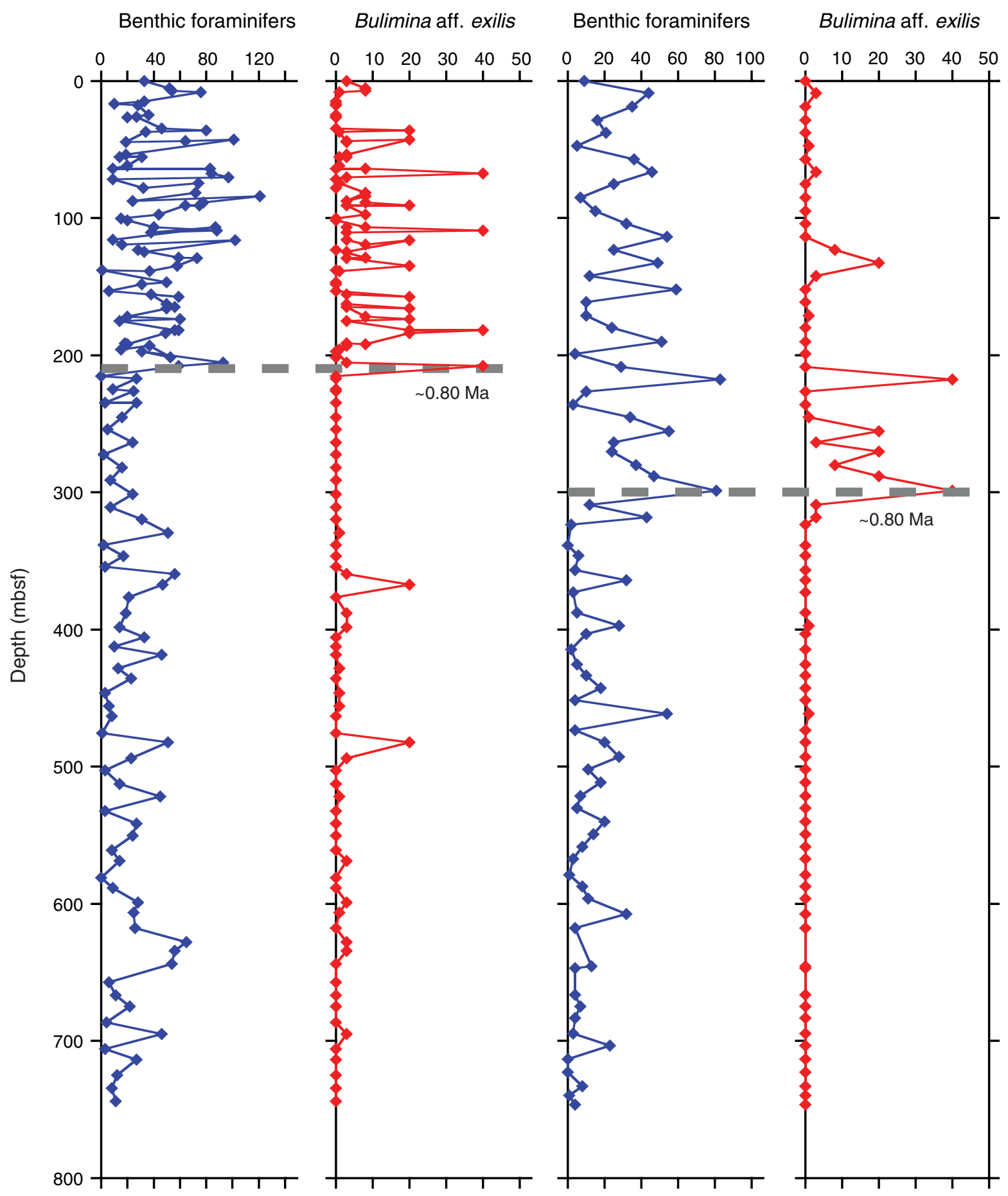


Figure F20. Inclination, declination, and intensity of remanent magnetization after $20 \mathrm{mT}$ AF demagnetization $\left(\mathrm{Int}_{20 \mathrm{mT}}\right)$, Hole U1344A. Raw declination values (blue) are shown with FlexIt-corrected values (black). Intensity data (black) are shown with STMSL magnetic susceptibility data (red).

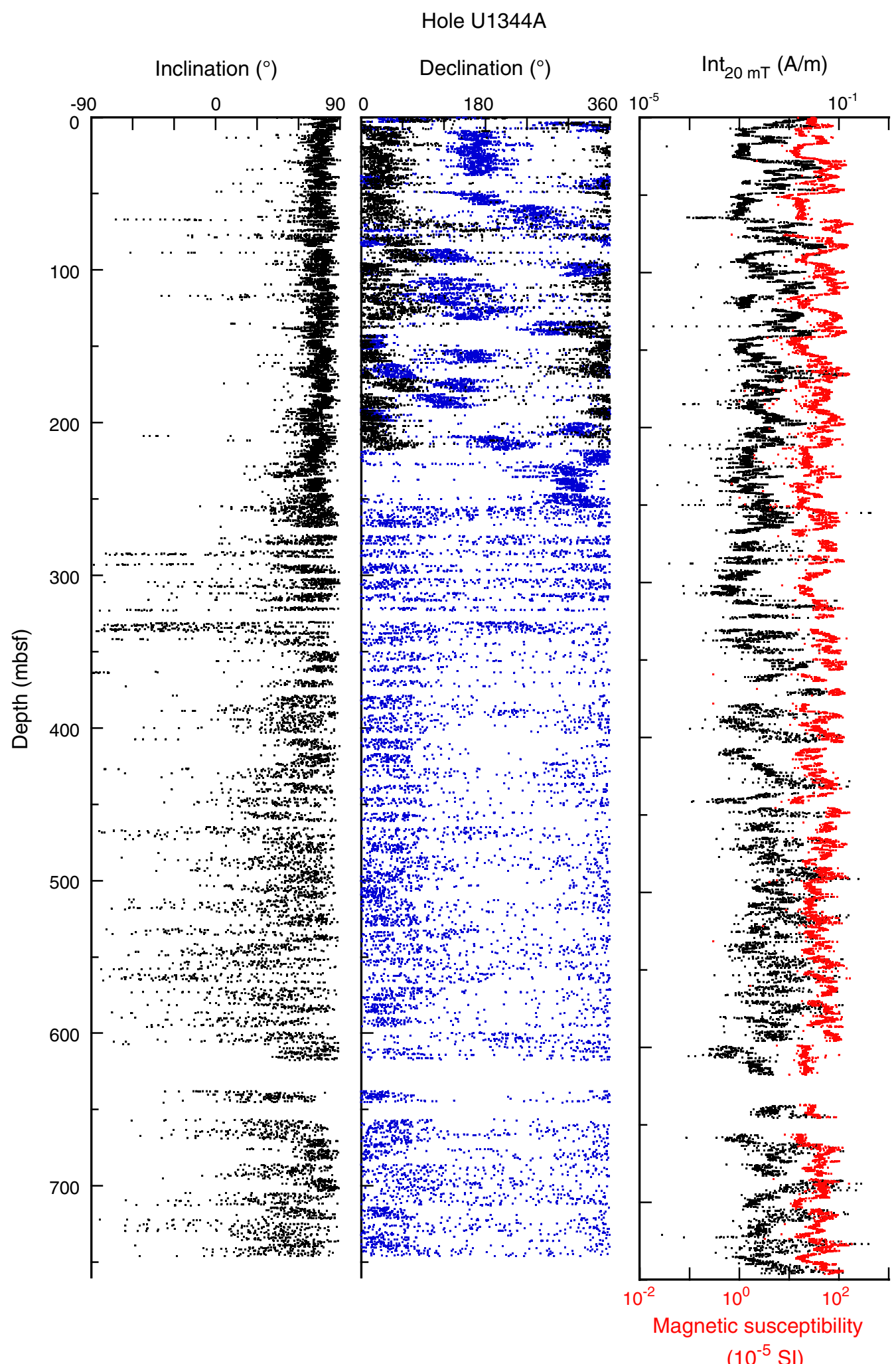


Figure F21. Inclination and intensity of remanent magnetization after $20 \mathrm{mT}$ AF demagnetization (Int $20 \mathrm{mT})$, Holes U1344D and U1344E. Intensity data (black) are shown with STMSL magnetic susceptibility data (red).

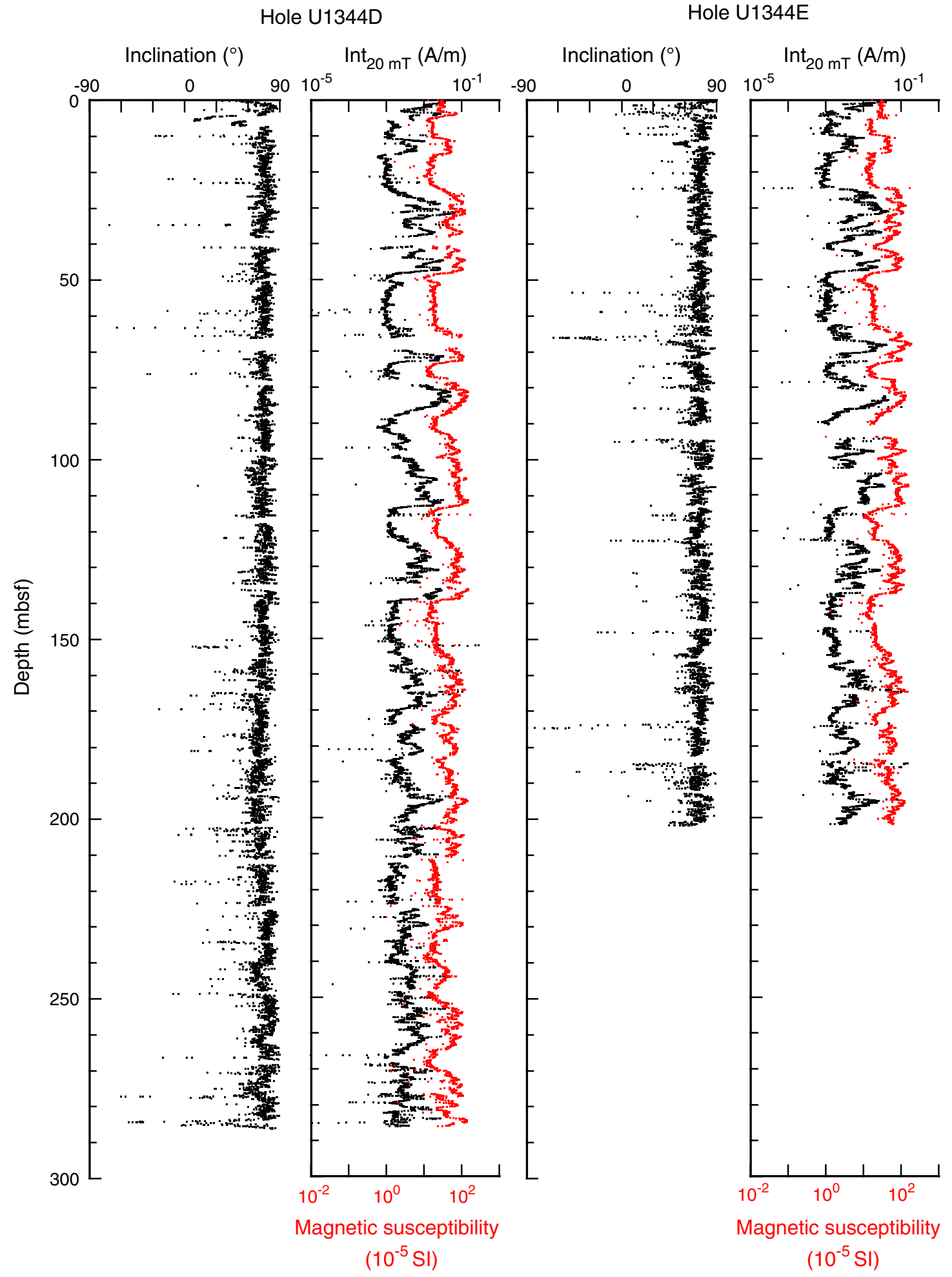


Figure F22. Inclination data (dots) and 60 point (corresponding to $\sim 0.5 \mathrm{~m}$ ) averaged inclination values (solid line) for Hole U1344A, along with tentative polarity zonation and presumable correlation with the polarity chrons. In the polarity zonation, black lines = normal polarity, gray lines = reversed or intermediate polarities, and white blanks = core gaps.

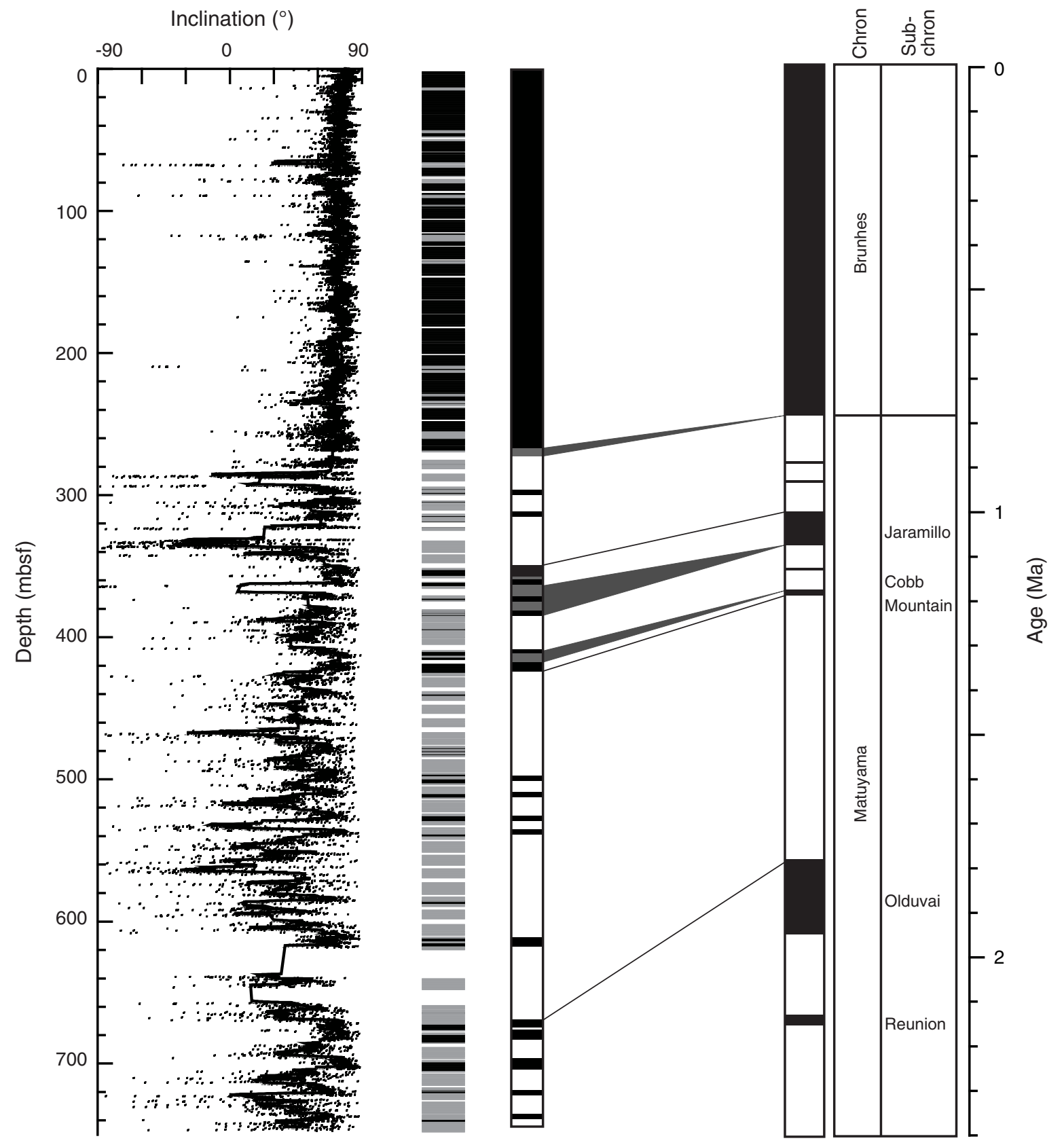


Figure F23. Magnetic susceptibility (top) and relative paleointensity (bottom) plotted against depth (mbsf), Hole U1344A. Relative paleointensity is estimated by normalizing natural remanent magnetization after $20 \mathrm{mT}$ demagnetization ( $\mathrm{Int}_{20 \mathrm{mT}}$ ) by magnetic susceptibility. Marine isotope Stages (MIS) 1-19 in the Brunhes Chron, numbered at top, were tentatively identified by correlating these features to other sites.

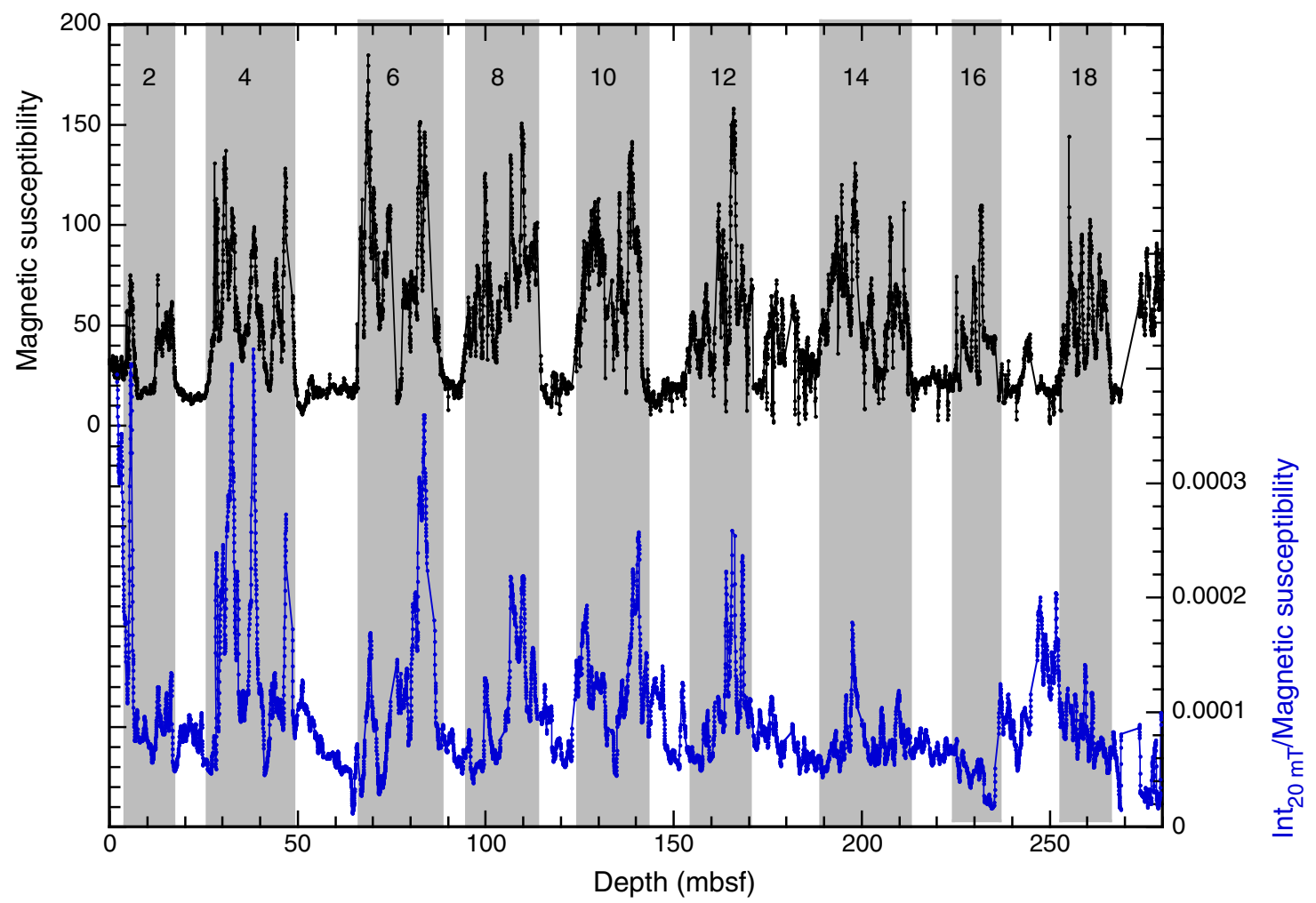


Figure F24. Dissolved chemical concentrations, Holes U1344A and U1344C. A. Calcium. B. Magnesium. C. Chloride. D. Sodium. E. Potassium. F. Strontium. G. Manganese. H. Iron. I. Lithium. J. Boron. K. Silica. L. Barium.
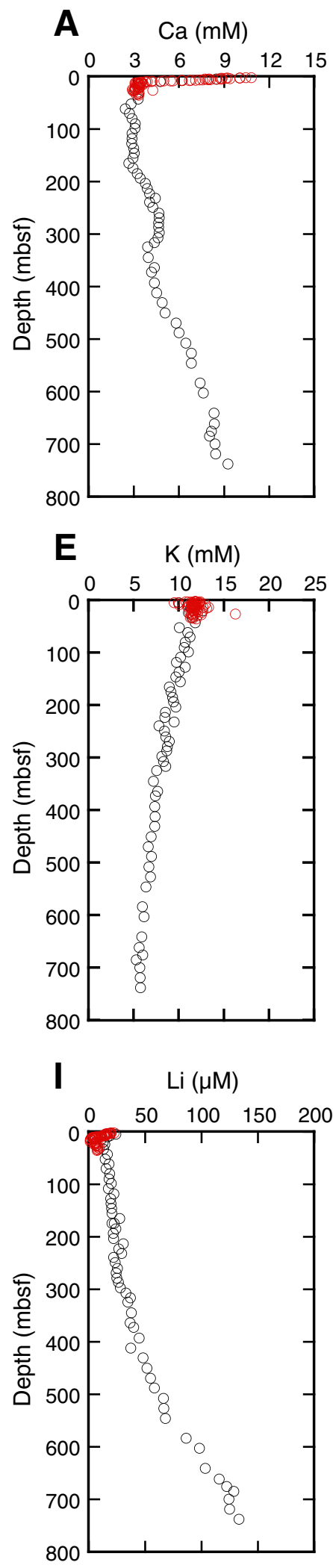
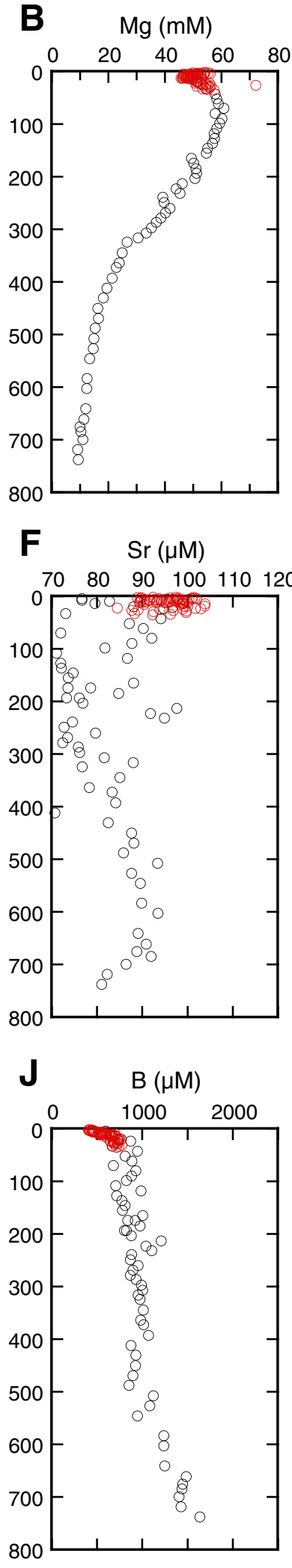

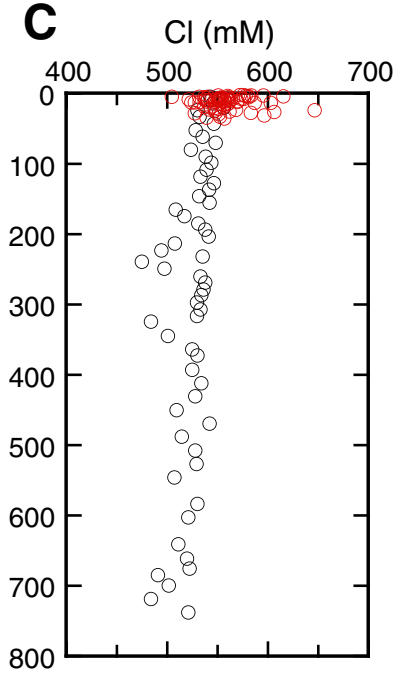

G $\quad \mathrm{Mn}(\mu \mathrm{M})$
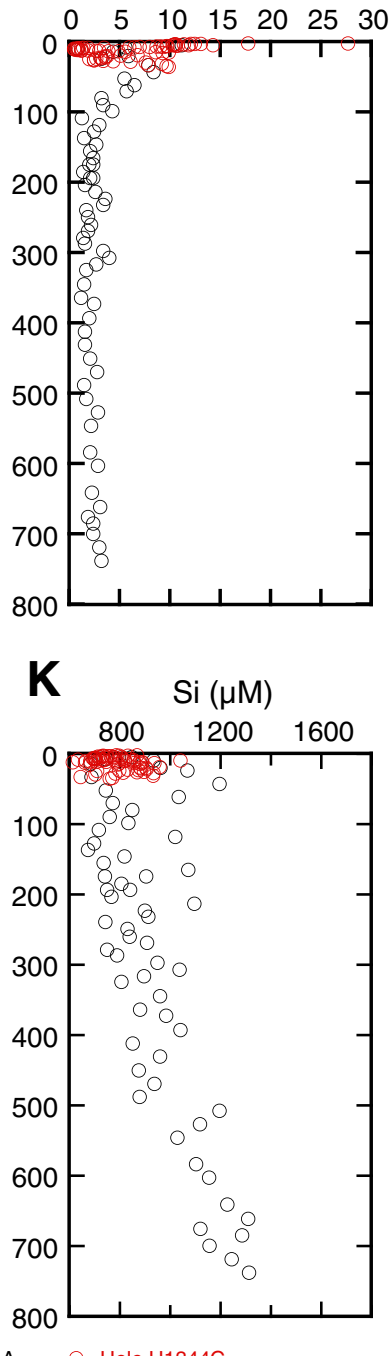

D $\quad \mathrm{Na}(\mathrm{mM})$
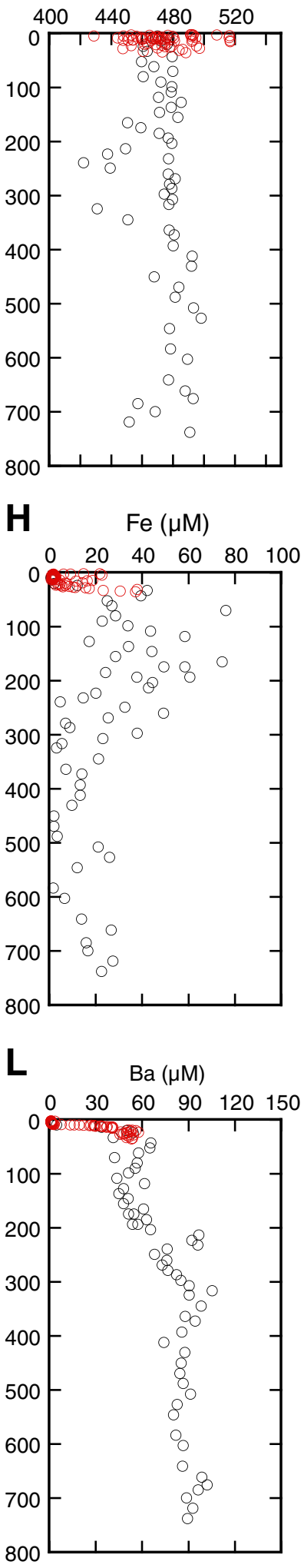
Figure F25. Dissolved chemical concentrations of pore water constituents, Holes U1344A and U1344C. A. Dissolved inorganic carbon (DIC). B. pH. C. Alkalinity. D. Sulfate. E. Methane. F. Total hydrogen sulfide $\left(\Sigma \mathrm{H}_{2} \mathrm{~S}=\right.$ $\left.\mathrm{H}_{2} \mathrm{~S}+\mathrm{HS}^{-}\right)$. G. Phosphate. H. Ammonium. I. Salinity. Note that $\mathrm{SO}_{4}{ }^{2-}, \mathrm{CH}_{4}$, and $\Sigma \mathrm{H}_{2} \mathrm{~S}$ depth profiles are reported only for the interval 0-15 mbsf.
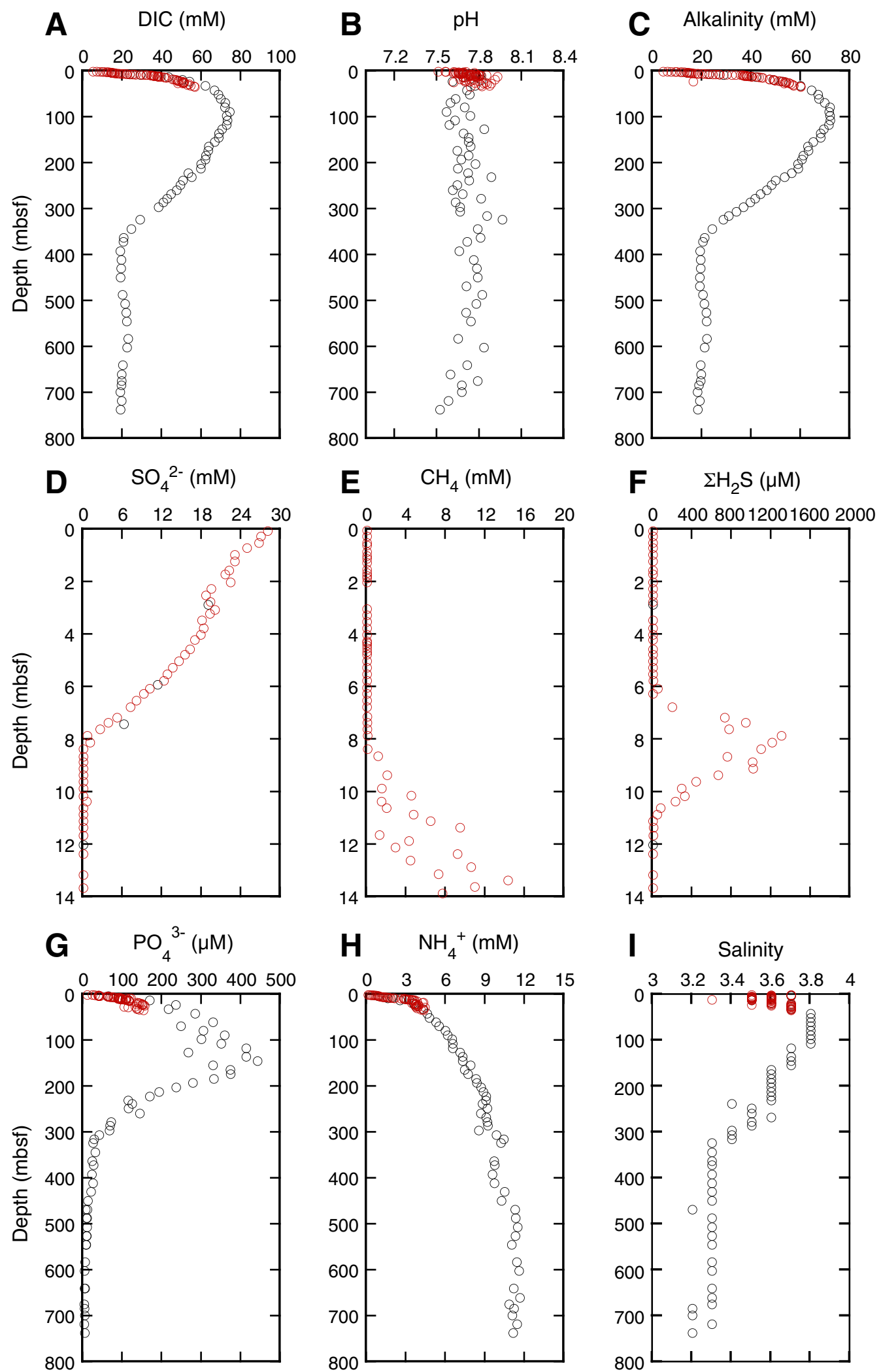

\section{H $\quad \mathrm{NH}_{4}^{+}(\mathrm{mM})$}
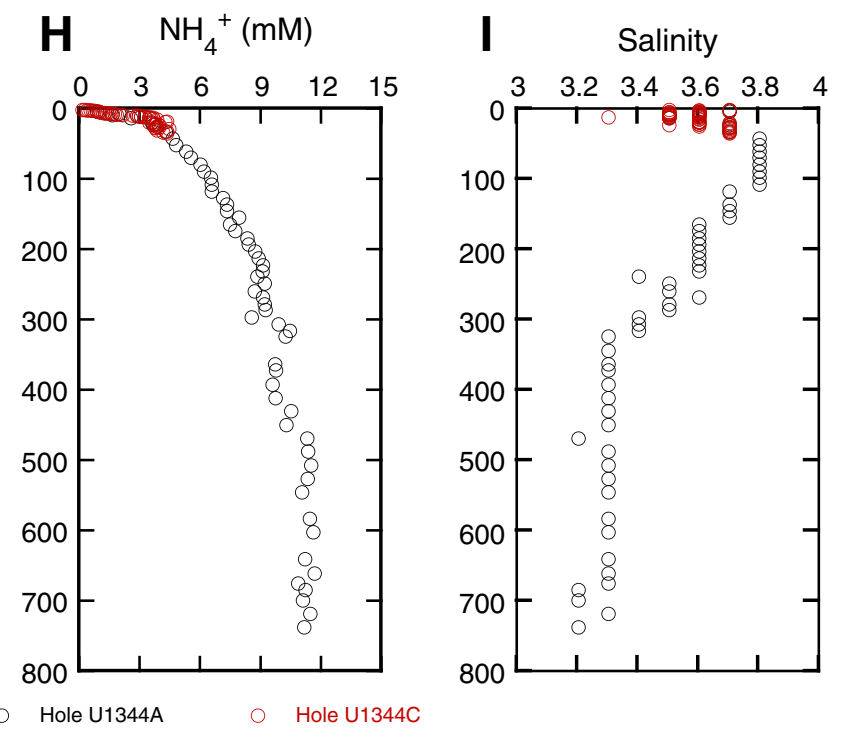
Figure F26. Solid-phase chemical concentrations, Hole U1344A. A. Calcium carbonate $\left(\mathrm{CaCO}_{3}\right)$. B. Total organic carbon (TOC). C. Total nitrogen (TN). D. Total sulfur (TS).

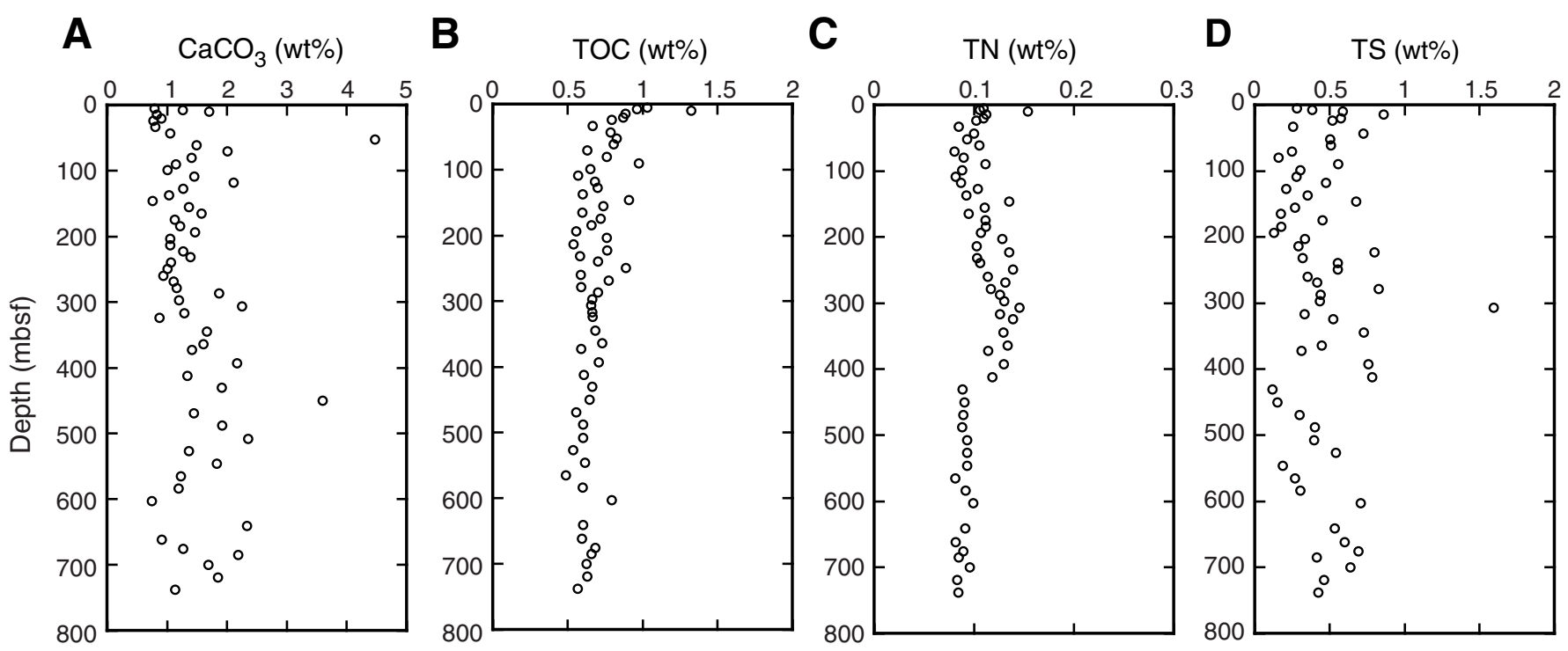


Figure F27. A. Downhole distribution of WRMSL gamma ray attenuation (GRA) wet bulk density, Hole U1344A. (Continued on next page.)

A

GRA wet bulk density $\left(\mathrm{g} / \mathrm{cm}^{3}\right)$

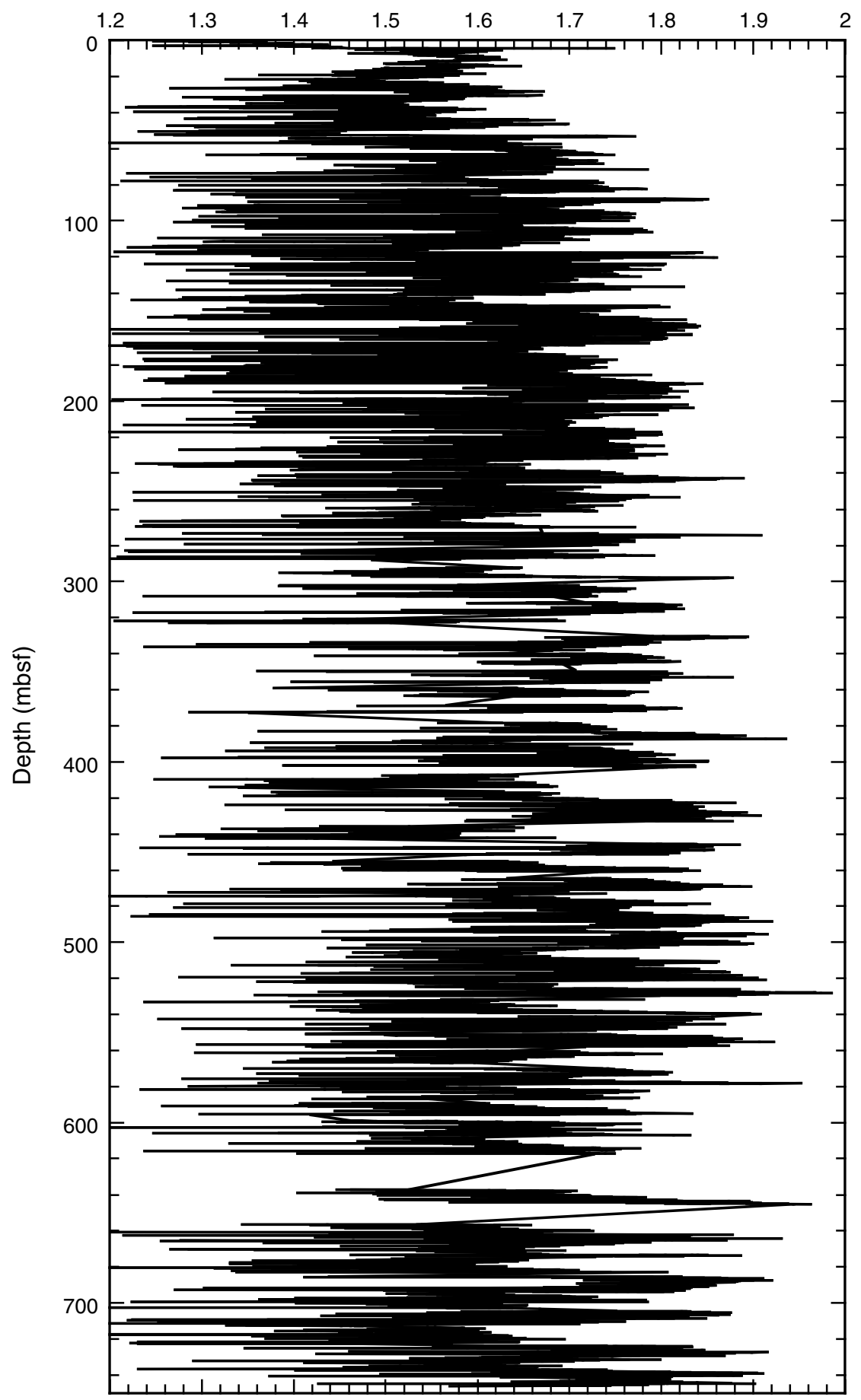

Figure U1344-H-1A 
Figure F27 (continued). B. Downhole distribution of wet bulk density measured by the triple combination logging tool, Hole U1344A (see "Downhole measurements").

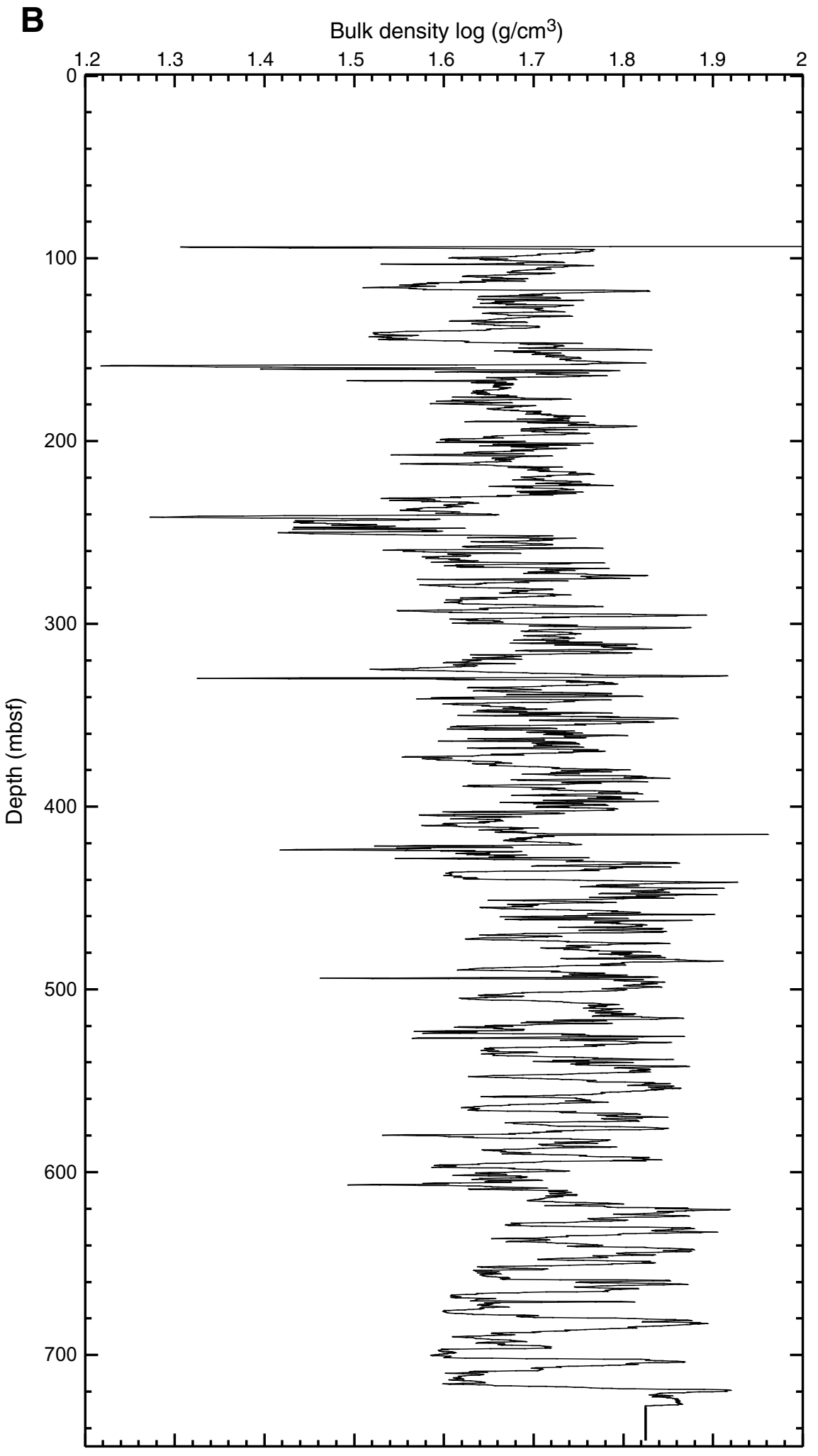


Figure F28. Downhole distribution of WRMSL magnetic susceptibility, Hole U1344A.

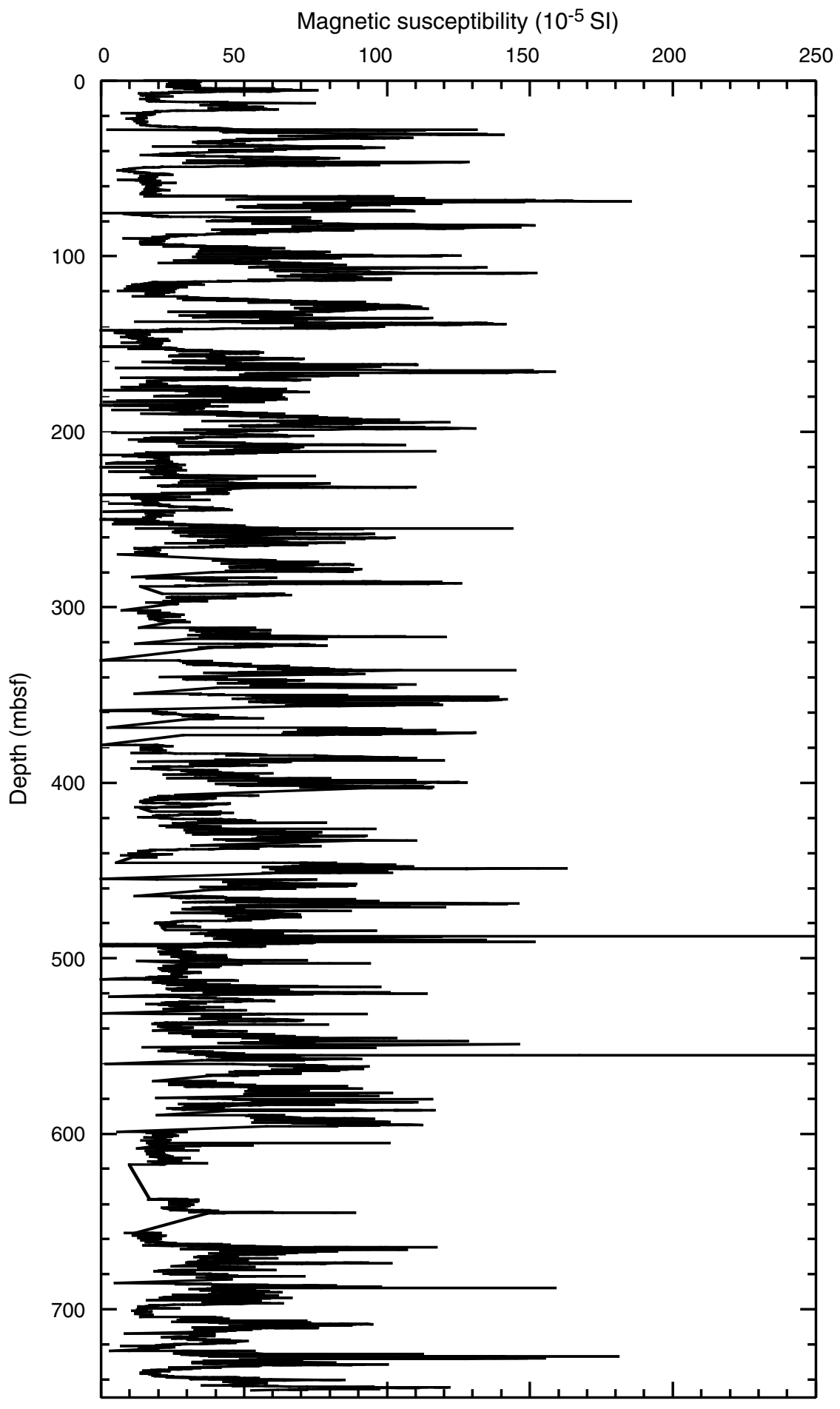


Figure F29. Downhole profile of $P$-wave velocity recorded by the FMS-sonic logging tool, Hole U1344A (see "Downhole measurements").

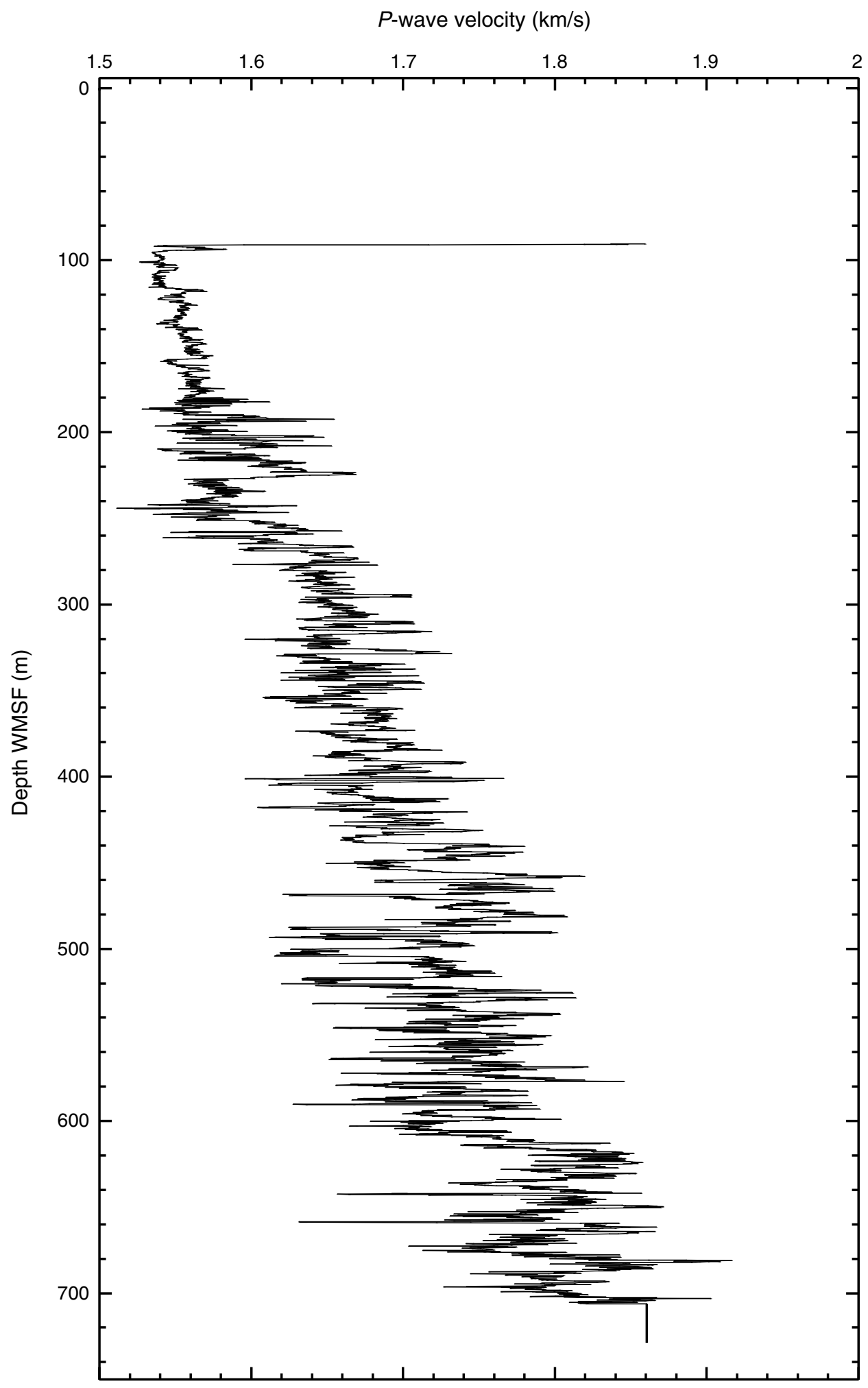


Figure F30. Downhole distribution of natural gamma ray (NGR) readings, Hole U1344A.

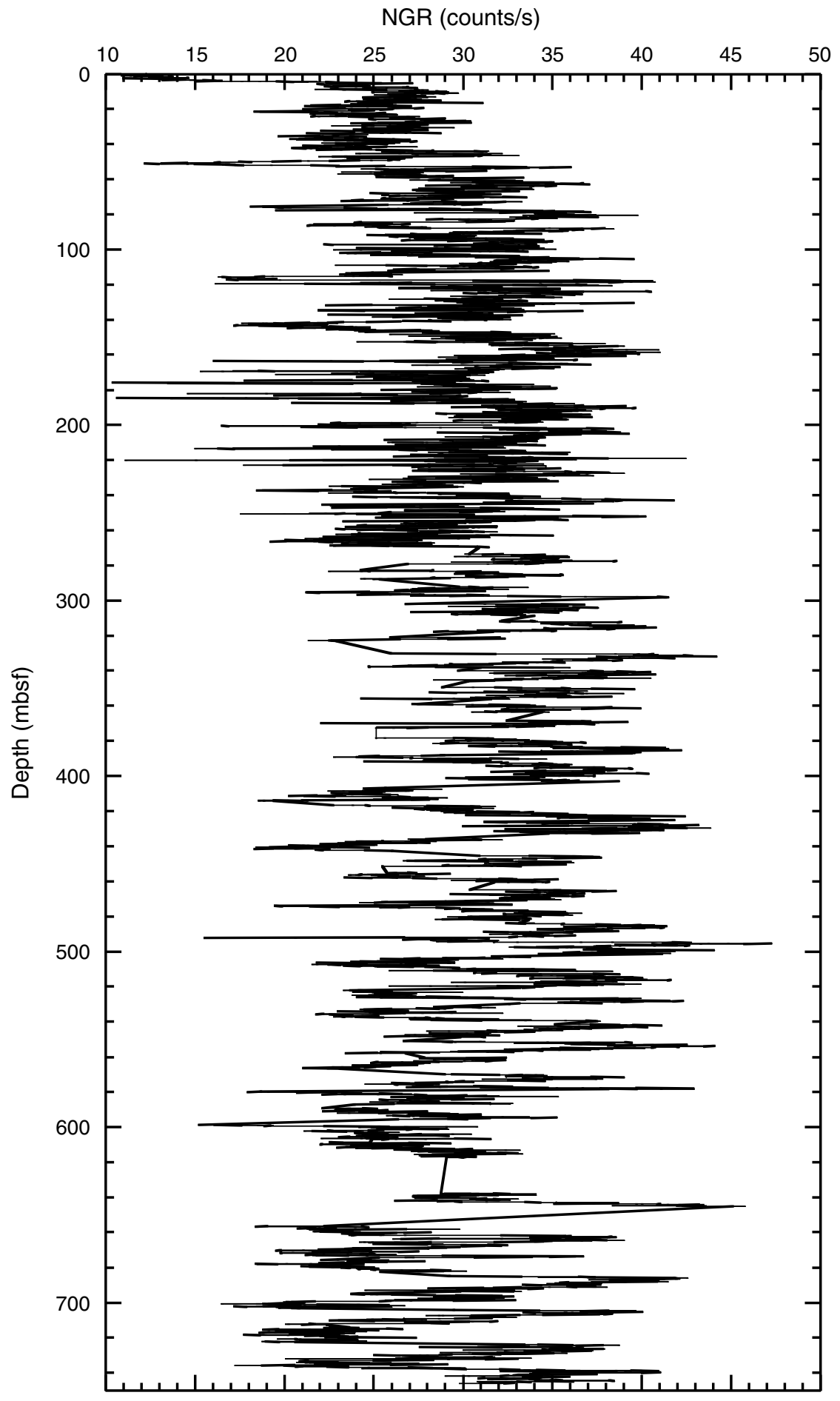


Figure F31. Downhole distribution of thermal conductivity measured mostly on Section 2 of Hole U1344A cores.

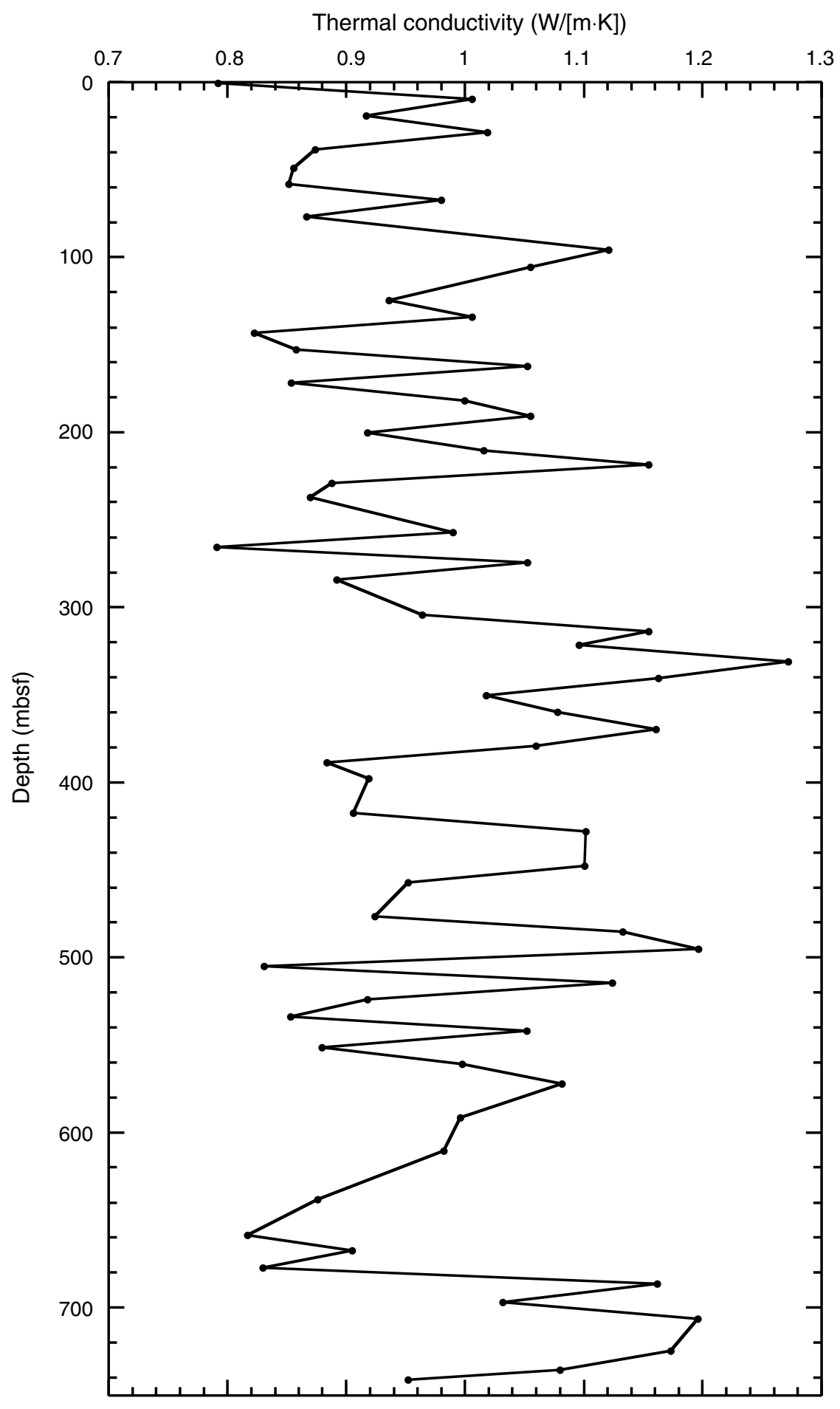


Figure F32. Downhole distribution of wet bulk density measured on discrete or moisture and density (MAD) sediment samples collected from Hole U1344A cores.

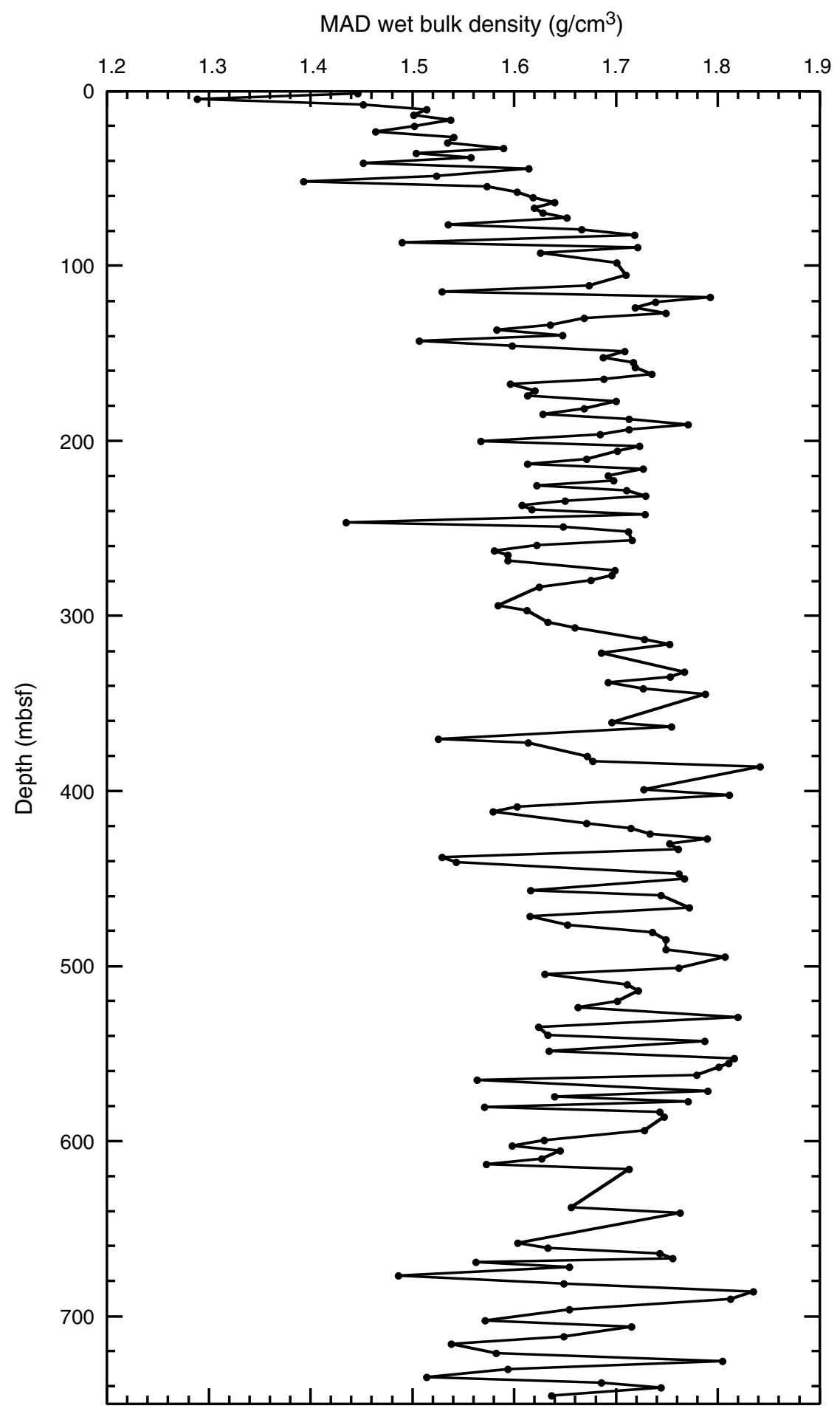


Figure F33. A. Downsection profiles of water content and porosity measured with moisture and density analyses of sediment samples taken from Hole U1344A cores. (Continued on next page.)

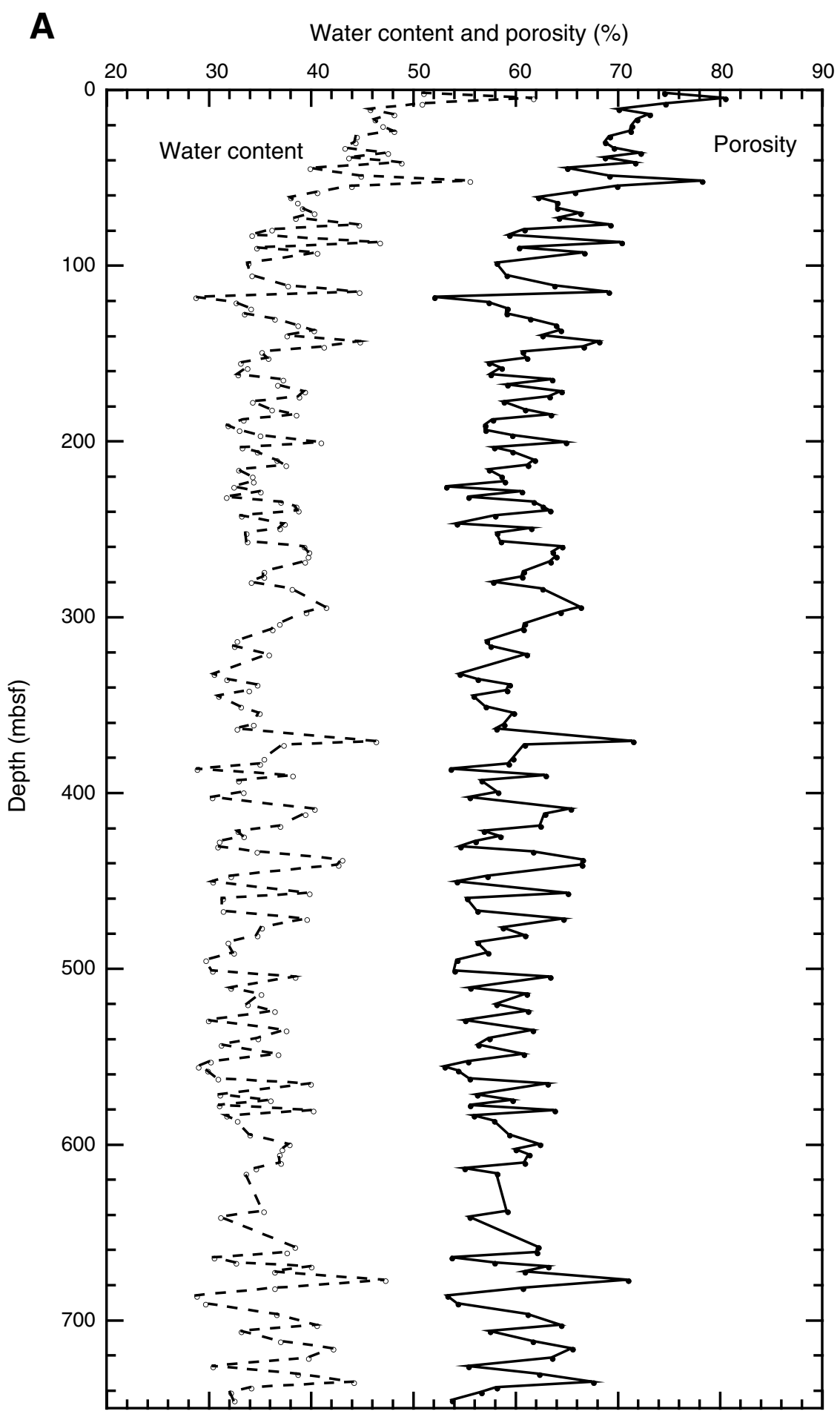


Figure F33 (continued). B. Downsection profile of porosity derived from the density log in Hole U1344A.

B Porosity from density (\%)

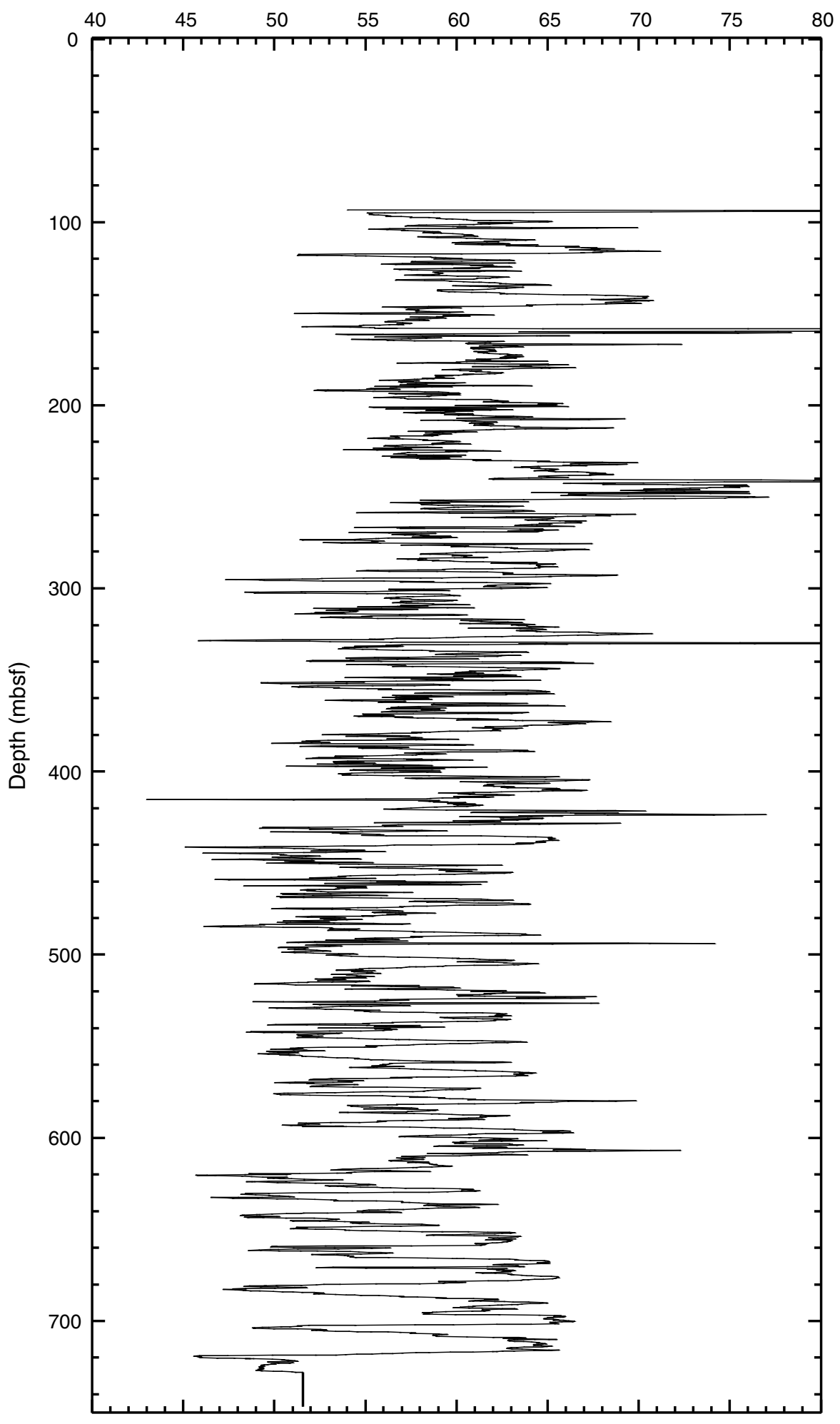


Figure F34. Downsection distribution of dry grain density by moisture and density analyses of sediment samples taken from Hole U1344A cores.

Dry grain density $\left(\mathrm{g} / \mathrm{cm}^{3}\right)$

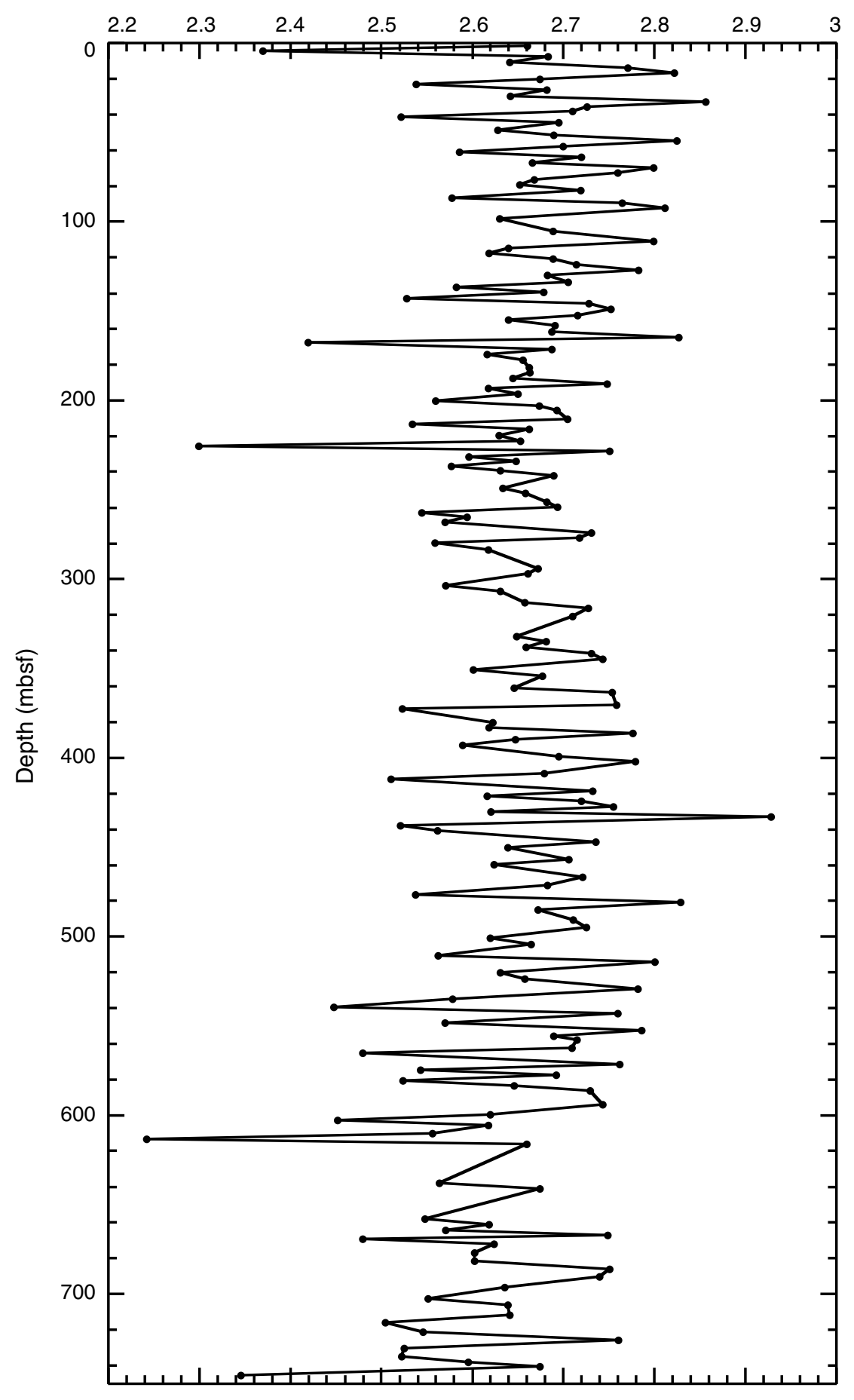


Figure F35. WRMSL magnetic susceptibility data for the interval of the continuous splice and the spliced record, Site U1344. STMSL magnetic susceptibility data are shown for Hole U1344C because cores from this hole were not run through the WRMSL. For the splice record (top panel), depth on the CCSF-D scale is equivalent to depth on the CCSF-A scale. A. 0-90 m CCSF-A. (Continued on next three pages.)

\section{A}
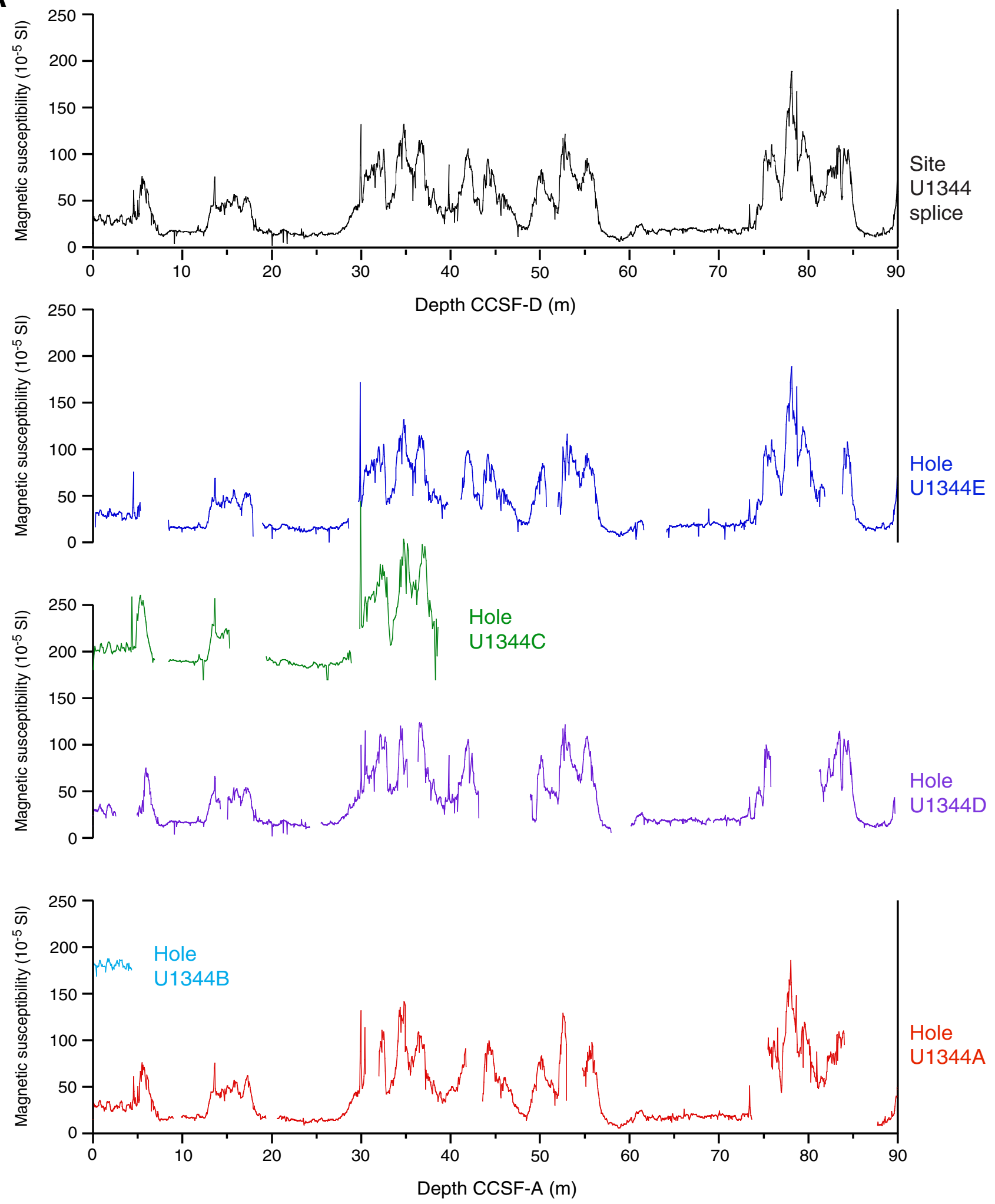
Figure F35 (continued). B. 90-180 m CCSF-A. (Continued on next page.)

B
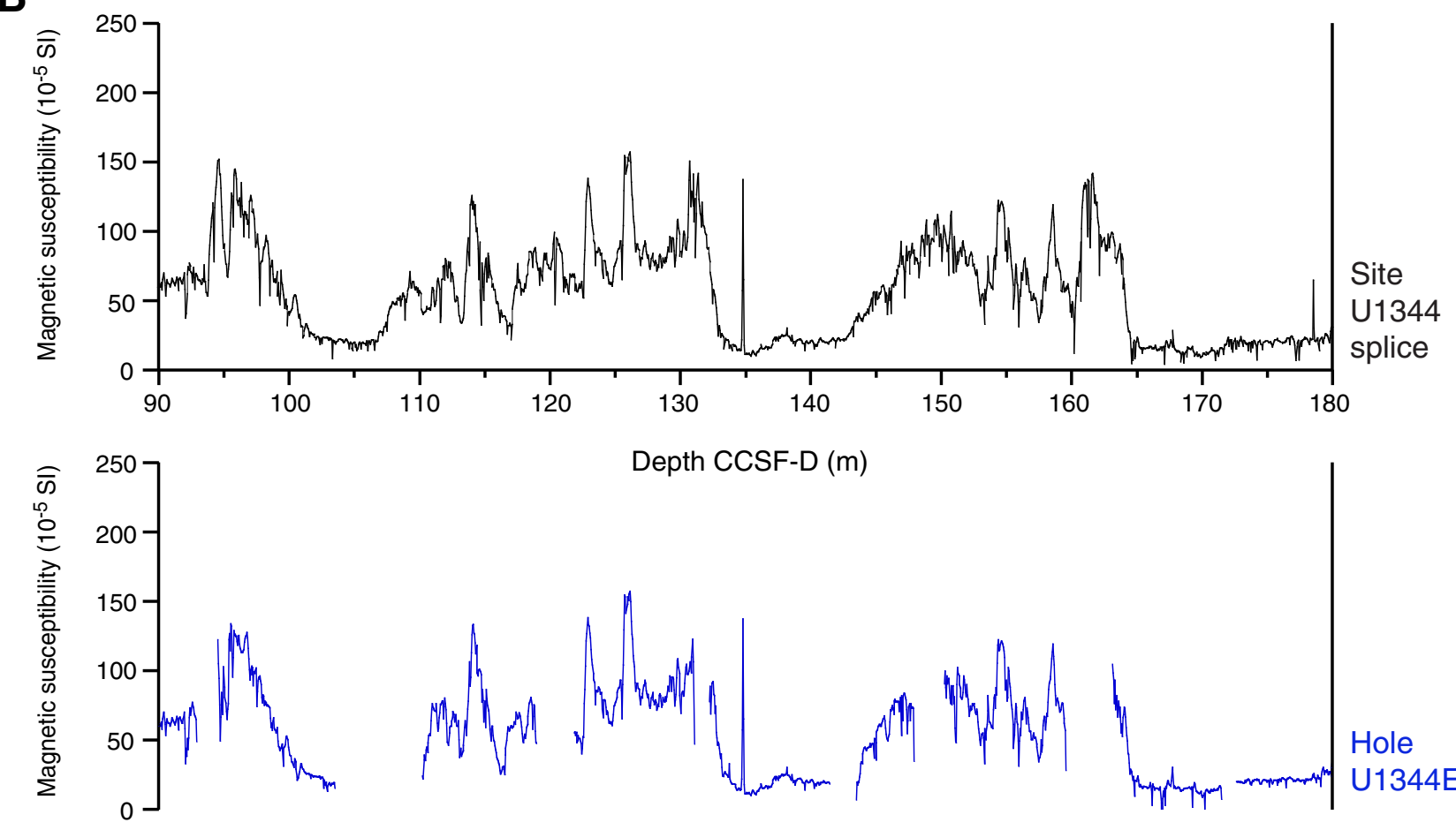

Depth CCSF-D (m)
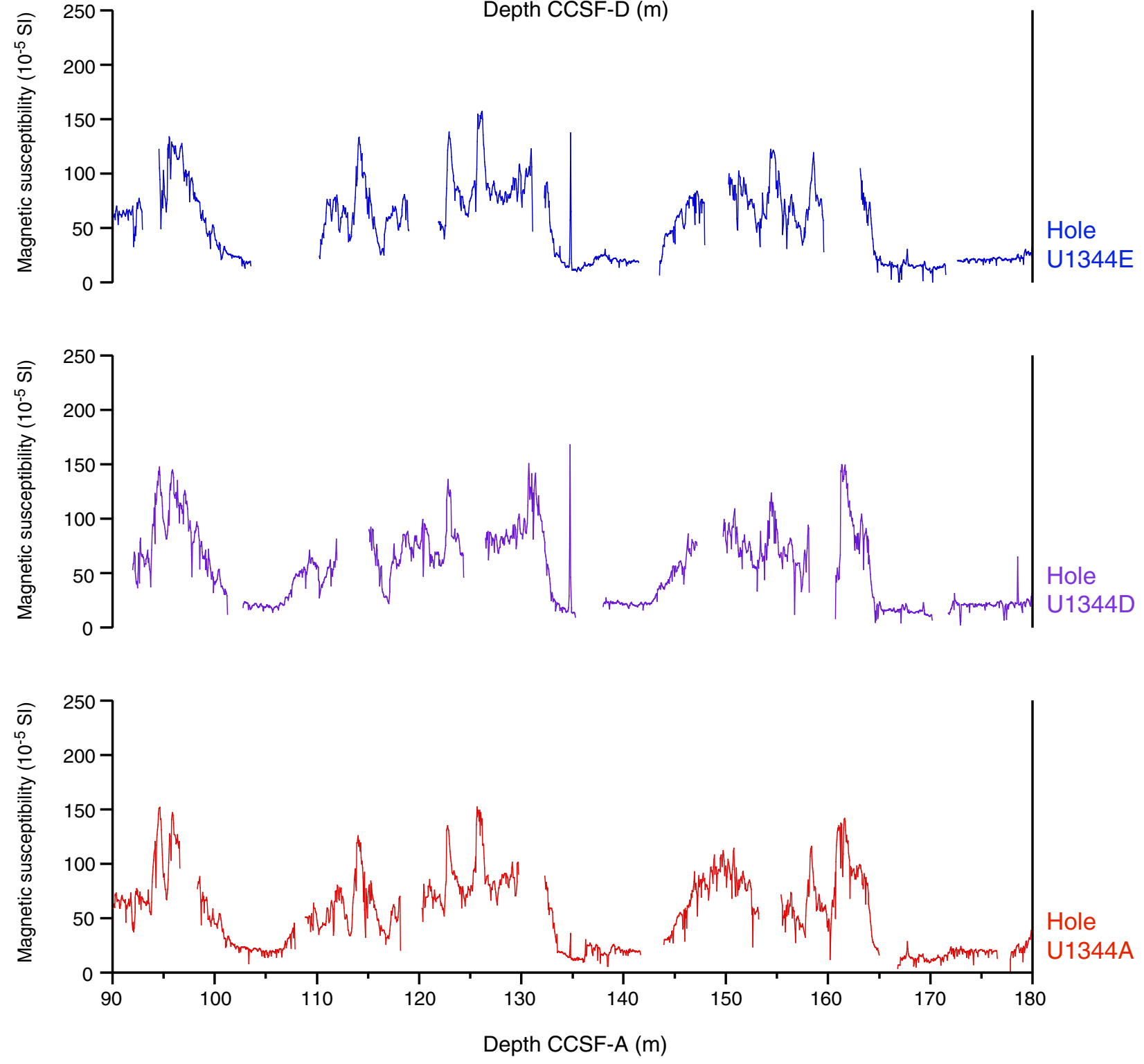
Figure F35 (continued). C. 180-270 m CCSF-A. (Continued on next page.)
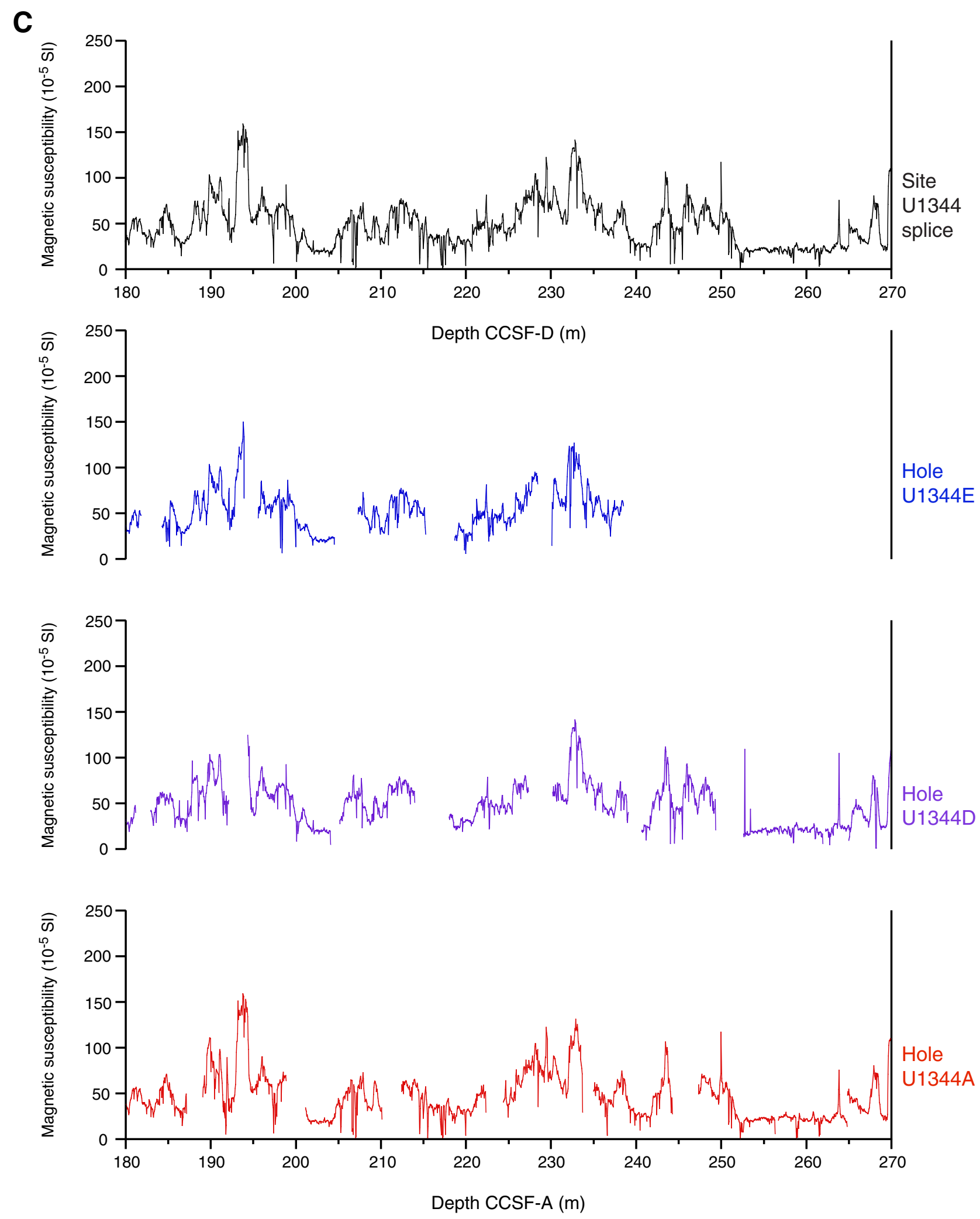
Figure F35 (continued). D. 270-360 m CCSF-A.

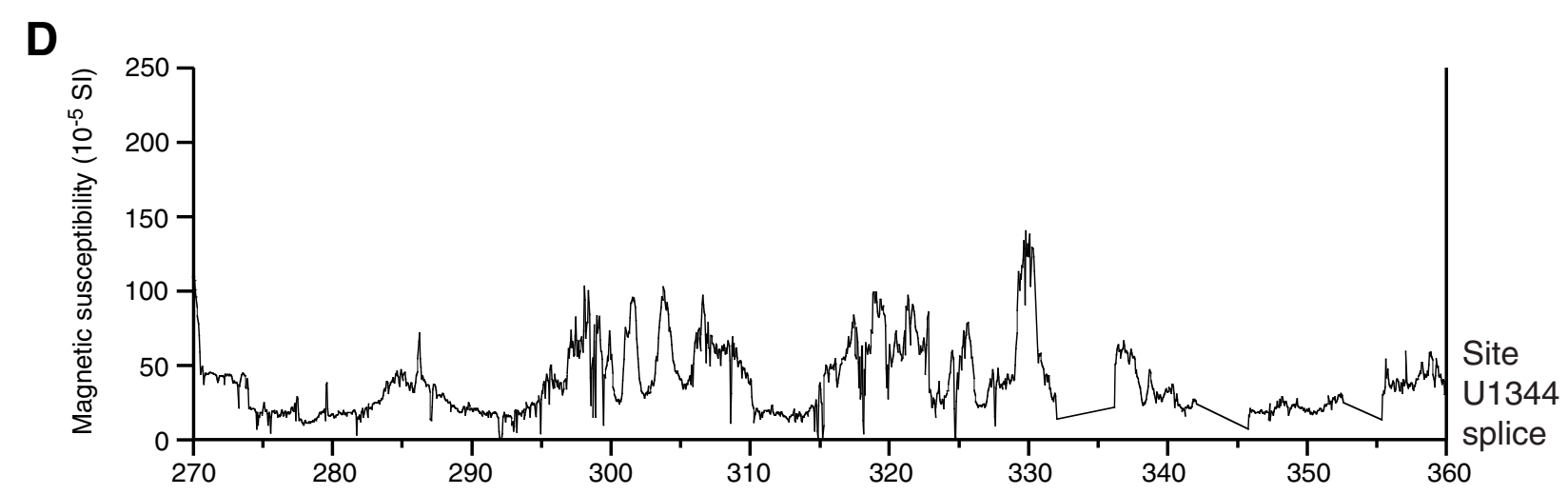

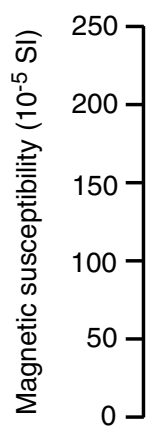

Depth CCSF-D (m)
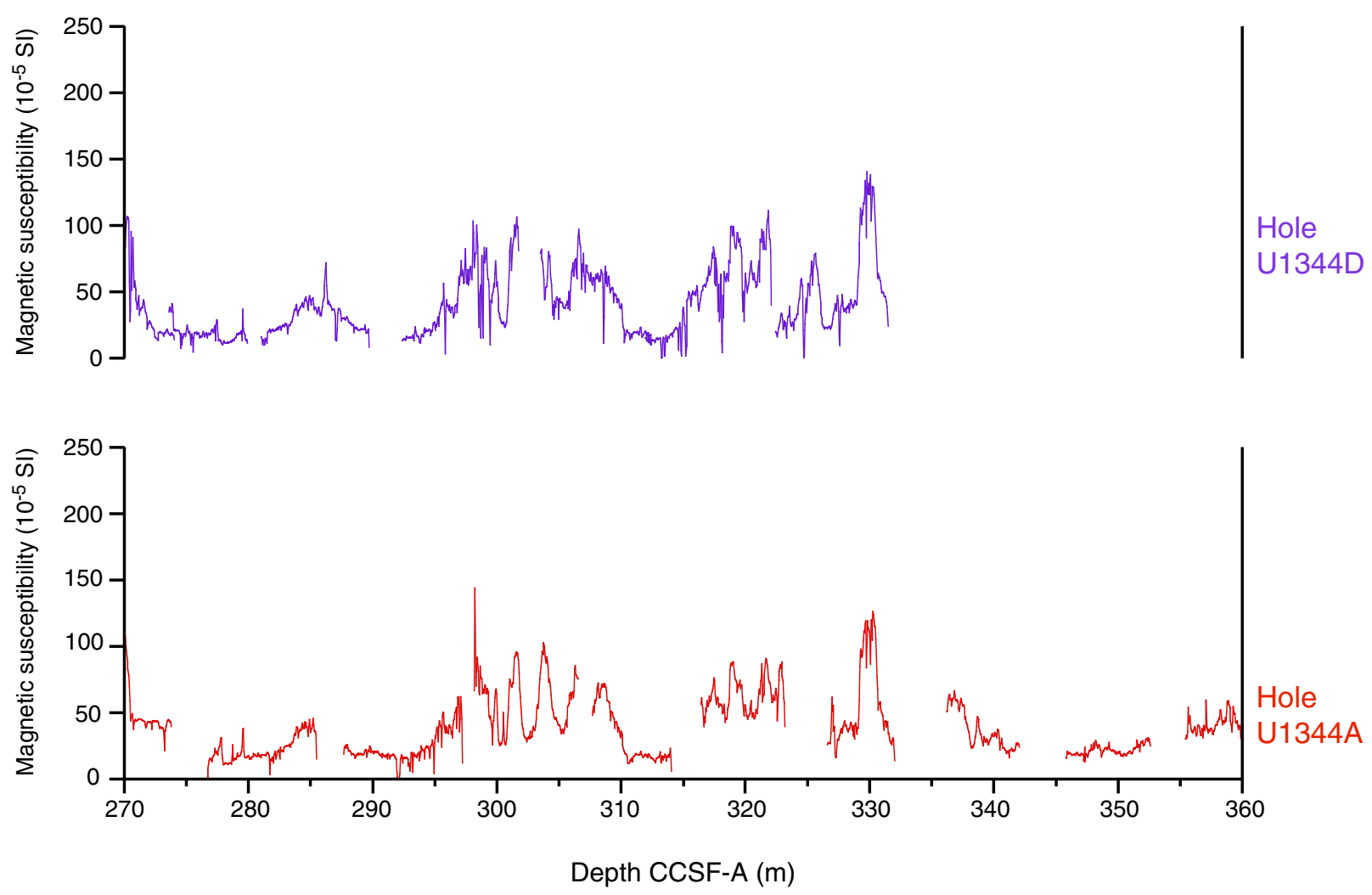
Figure F36. WRMSL gamma ray attenuation (GRA) bulk density vs. composite depth for the interval of the continuous splice and the spliced record, Site U1344. STMSL GRA bulk density data are shown for Hole U1344C because cores from this hole were not run through the WRMSL. For the splice record (top panel), depth on the CCSF-D scale is equivalent to depth on the CCSF-A scale. A. 0-90 m CCSF-A. (Continued on next three pages.)
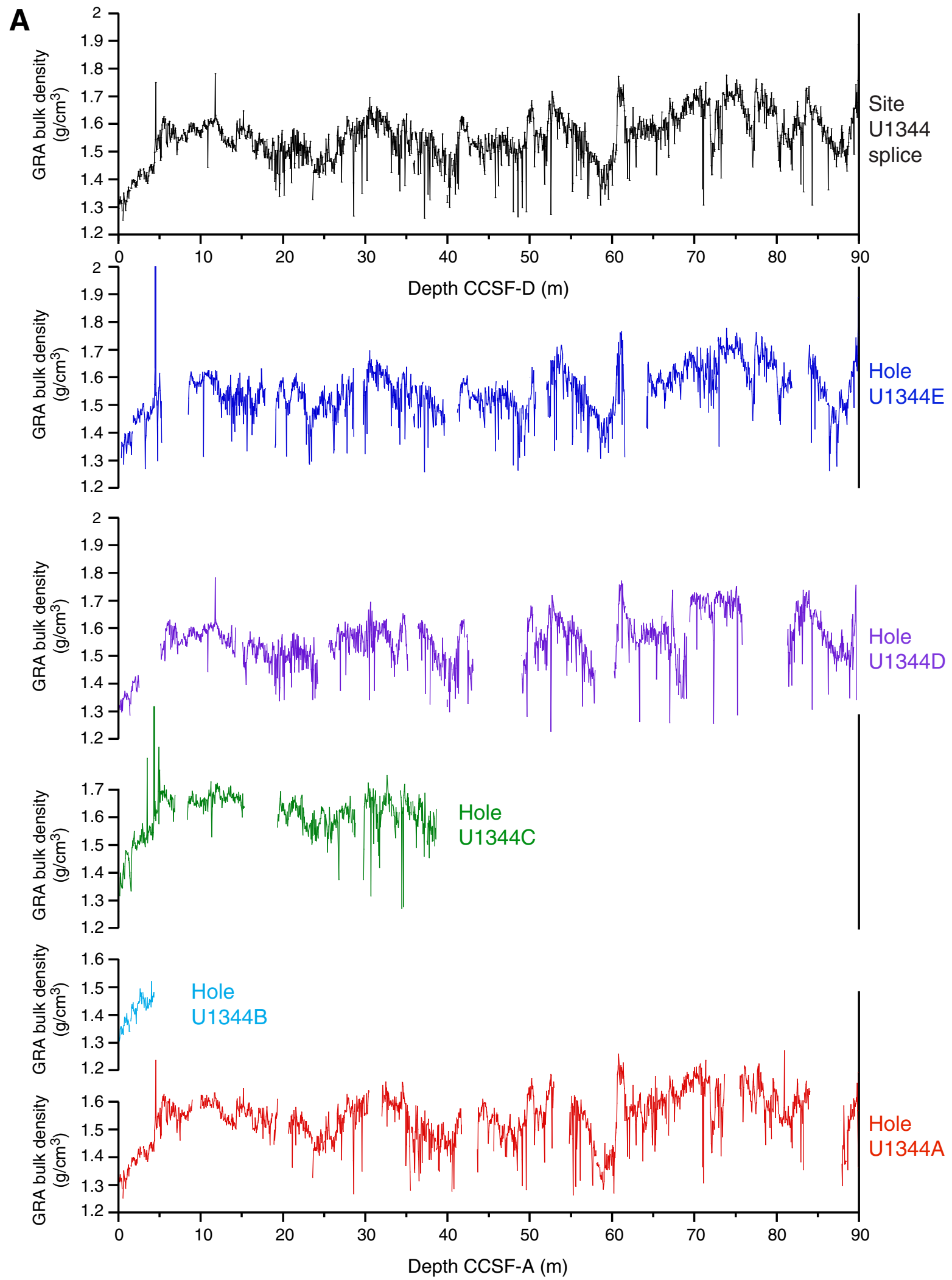
Figure F36 (continued). B. 90-180 m CCSF-A. (Continued on next page.)

B
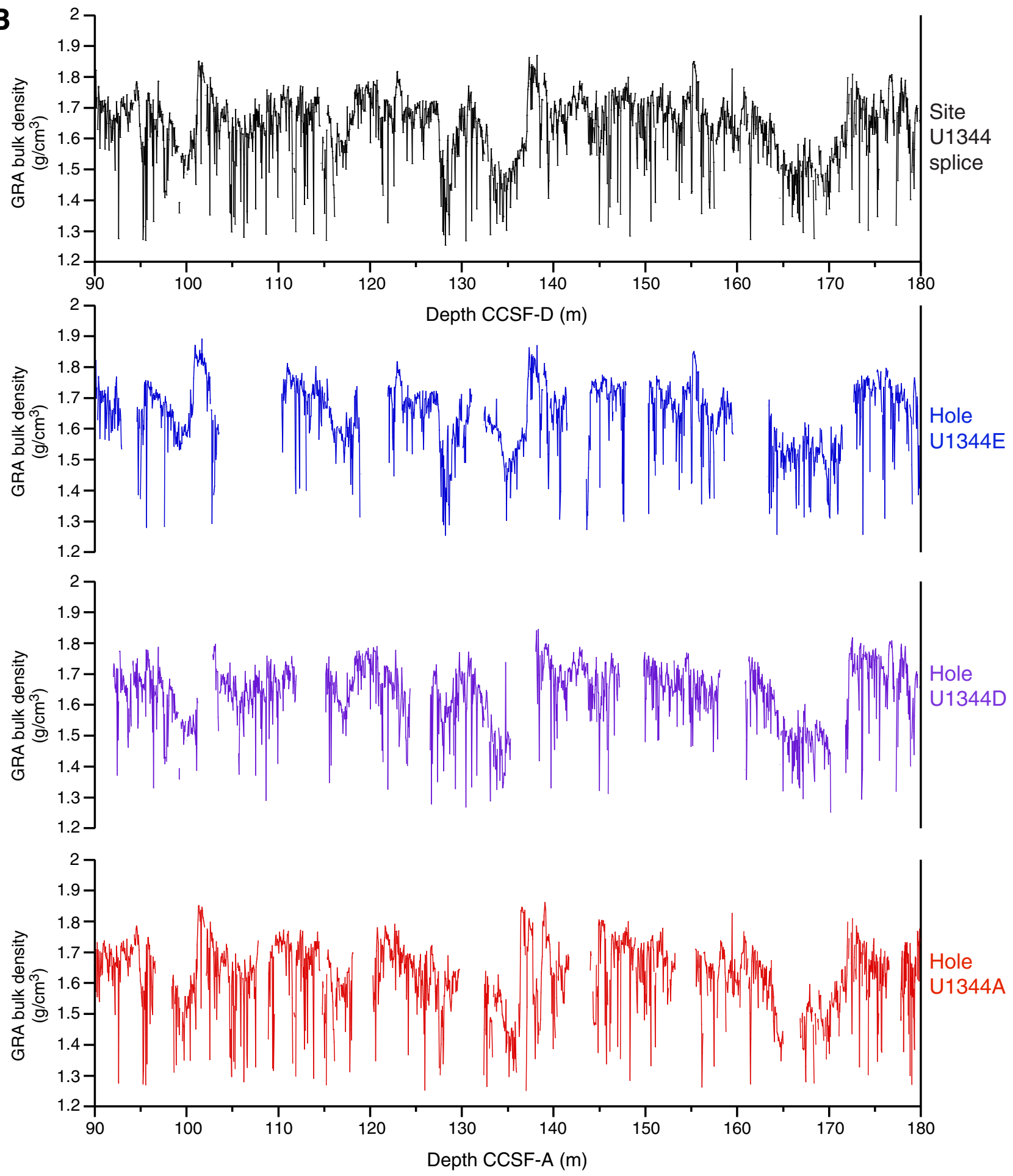
Figure F36 (continued). C. 180-270 m CCSF-A. (Continued on next page.)
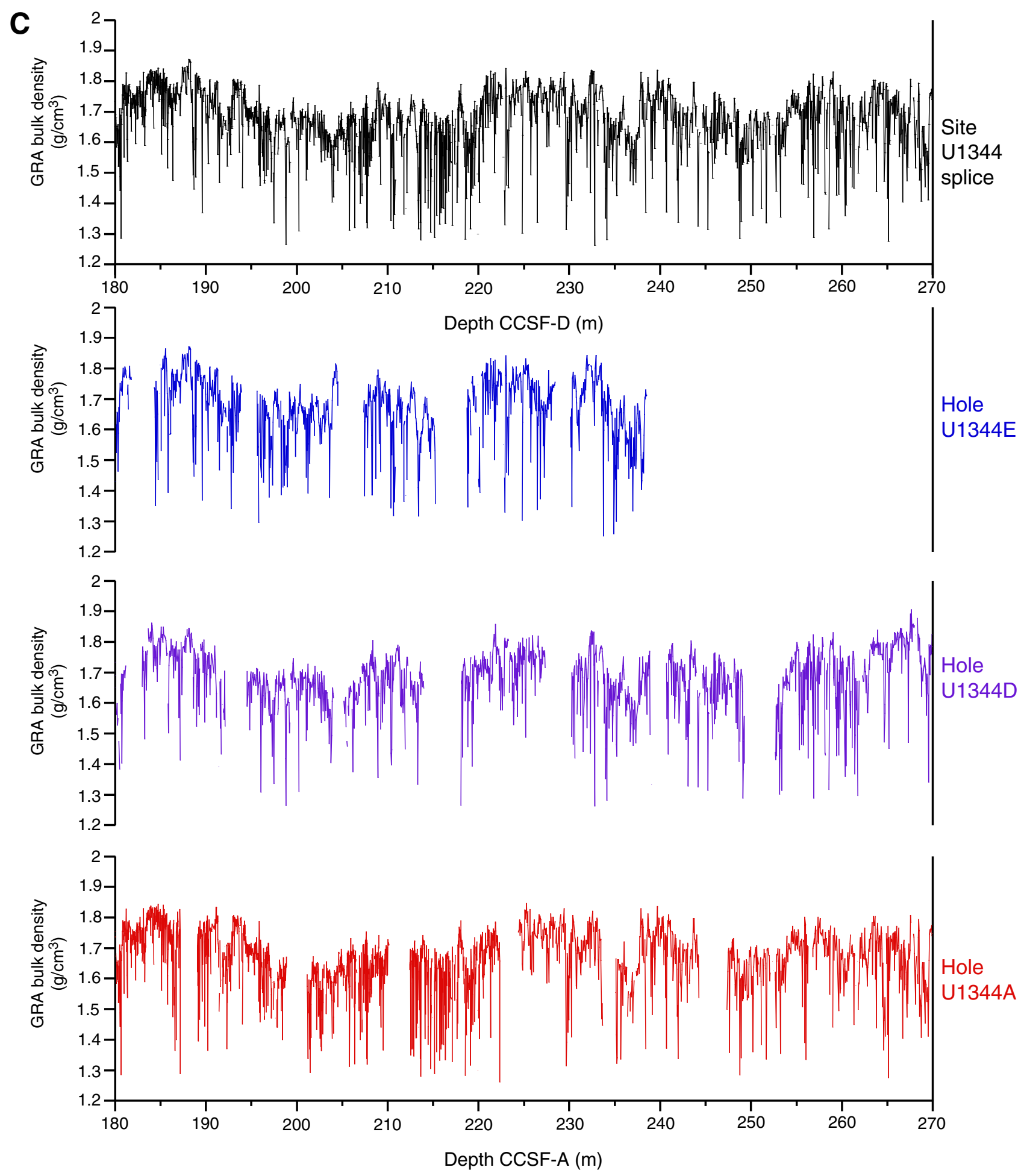
Figure F36 (continued). D. 270-360 m CCSF-A.
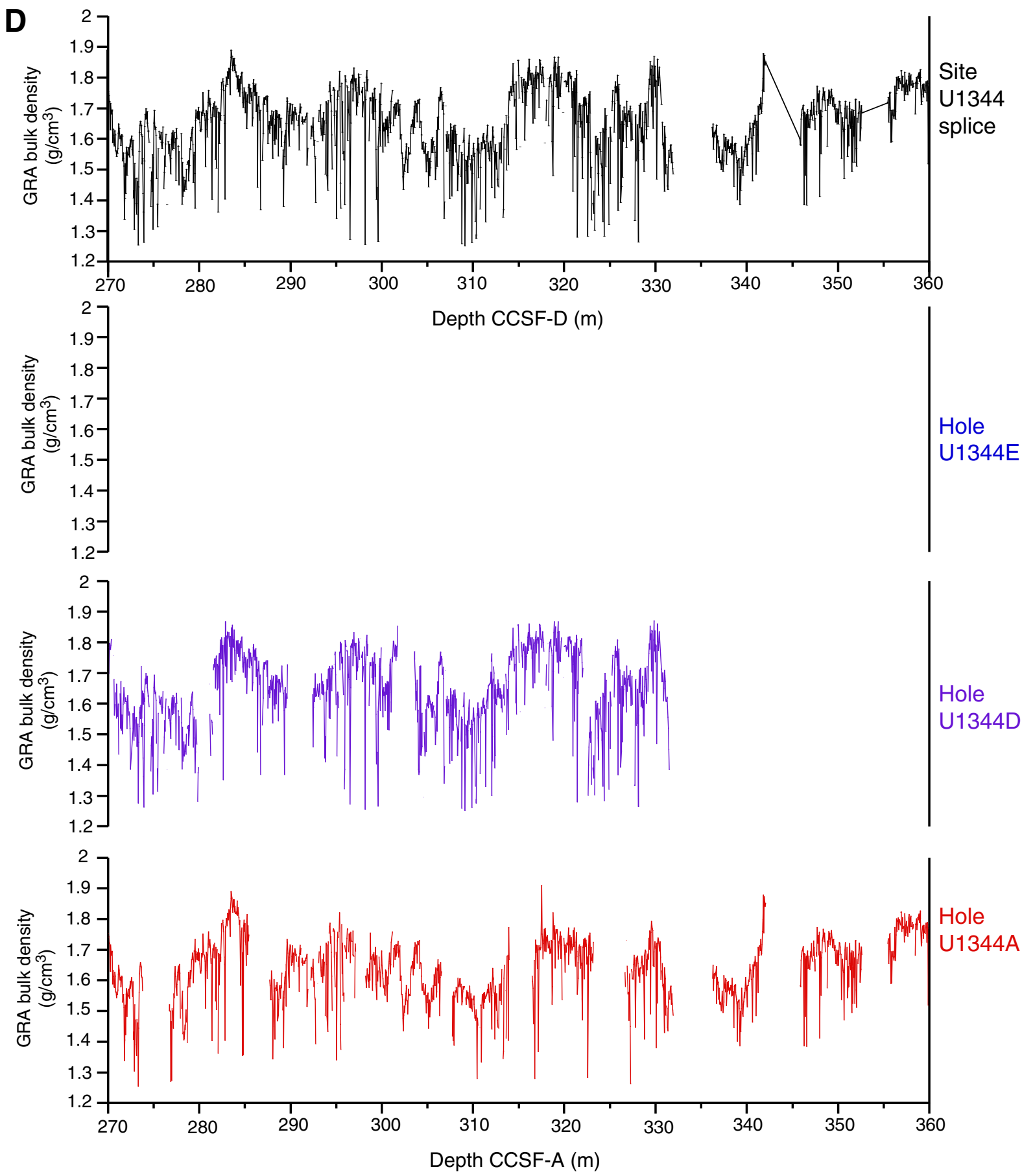
Figure F37. Natural gamma radiation (NGR) data collected with the Natural Gamma Radiation Logger vs. composite depth for the interval of the continuous splice and the spliced record, Site U1344. No NGR data are available for Hole U1344C. For the splice record (top panel), depth on the CCSF-D scale is equivalent to depth on the CCSF-A scale. A. 0-90 m CCSF-A. (Continued on next three pages.)

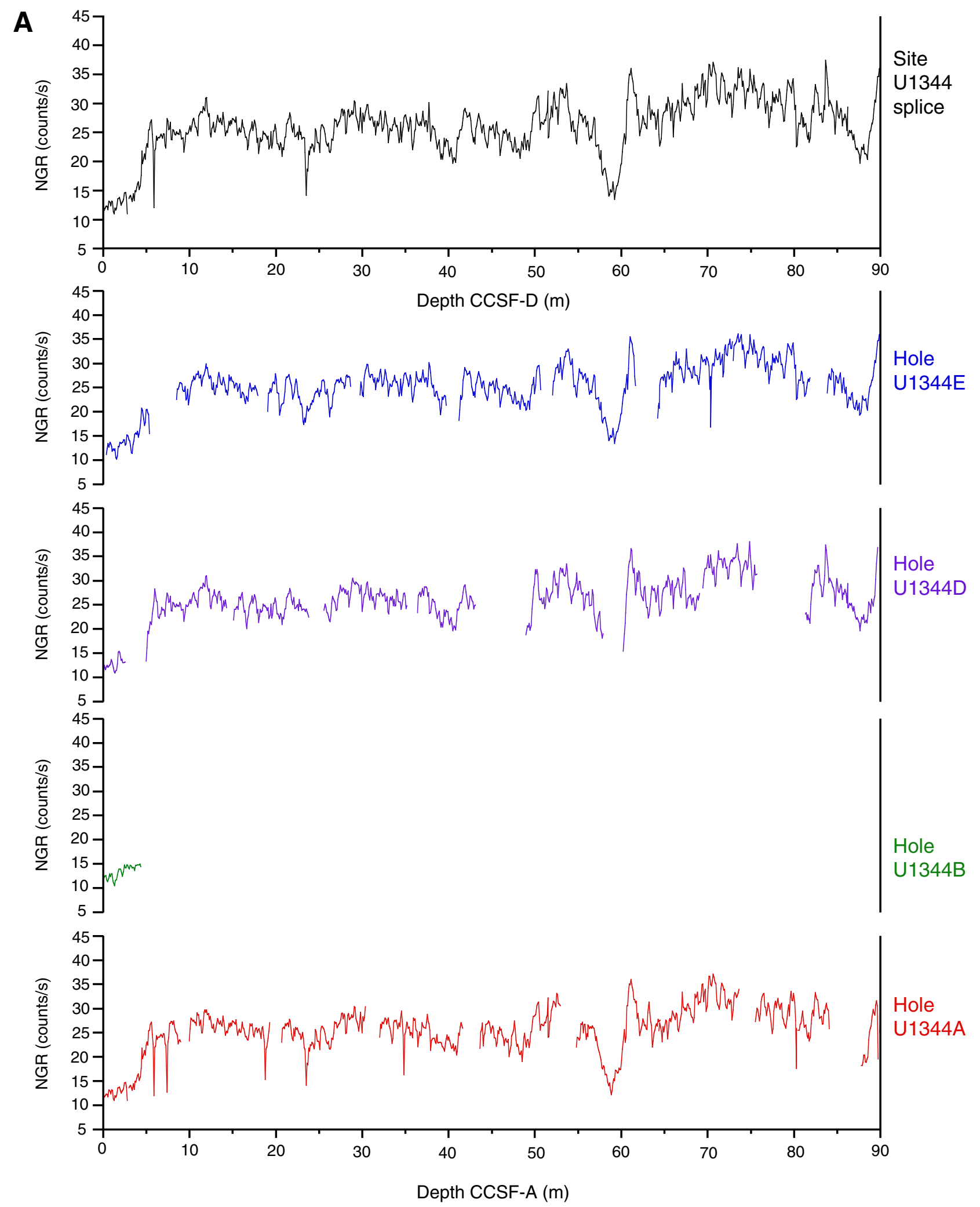


Figure F37 (continued). B. 90-180 m CCSF-A. (Continued on next page.)
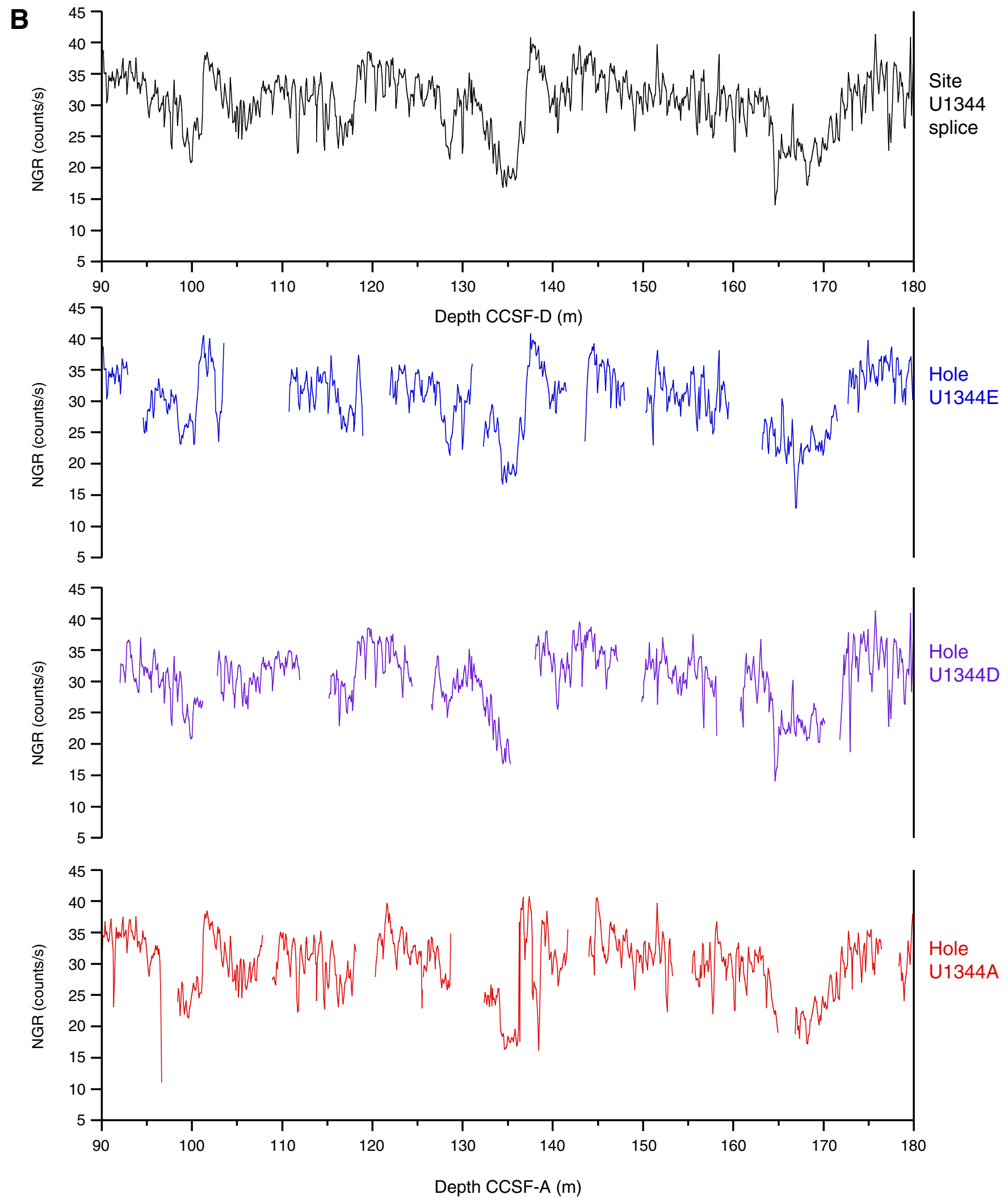
Figure F37 (continued). C. 180-270 m CCSF-A. (Continued on next page.)
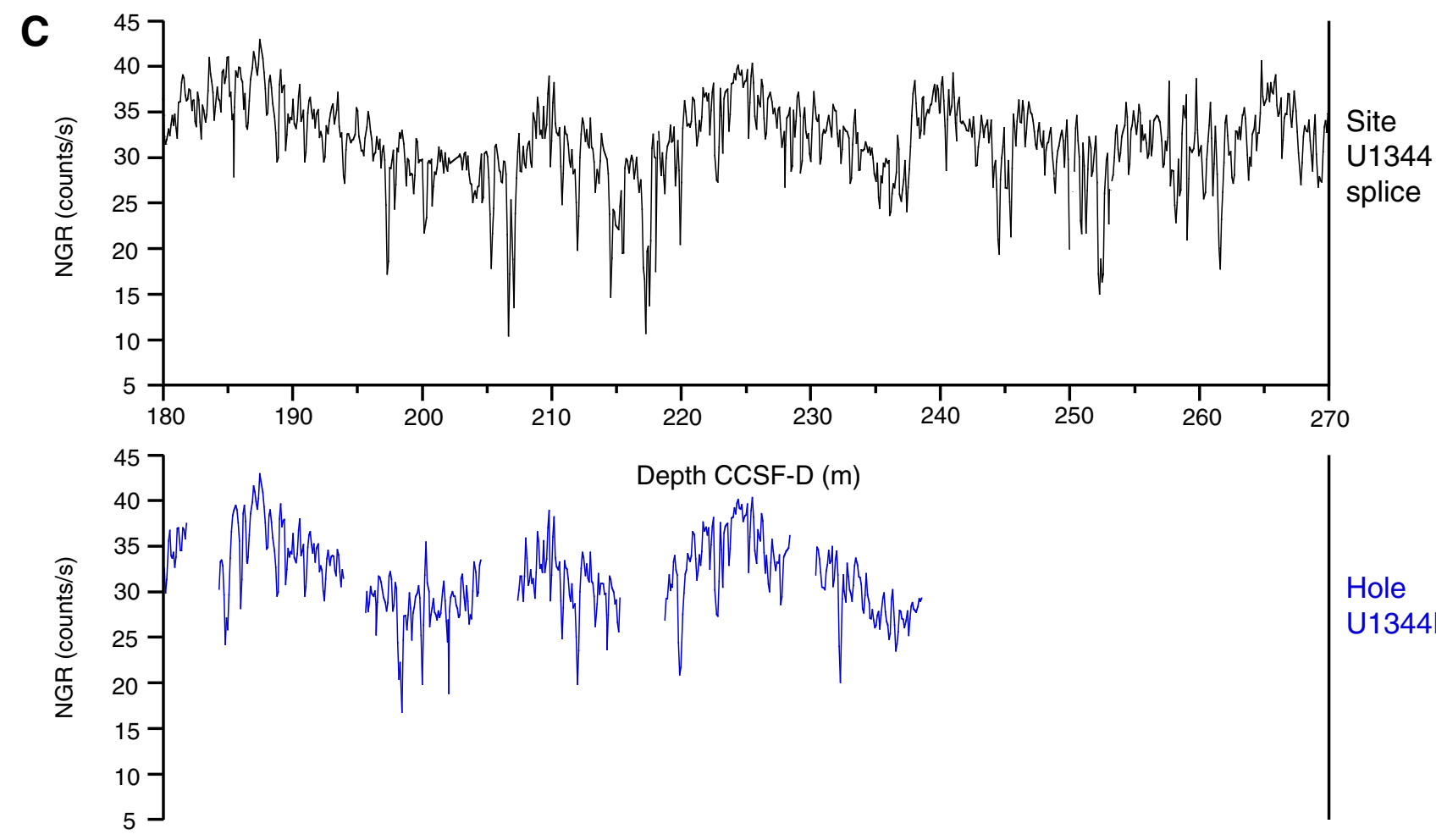

Hole

U1344E
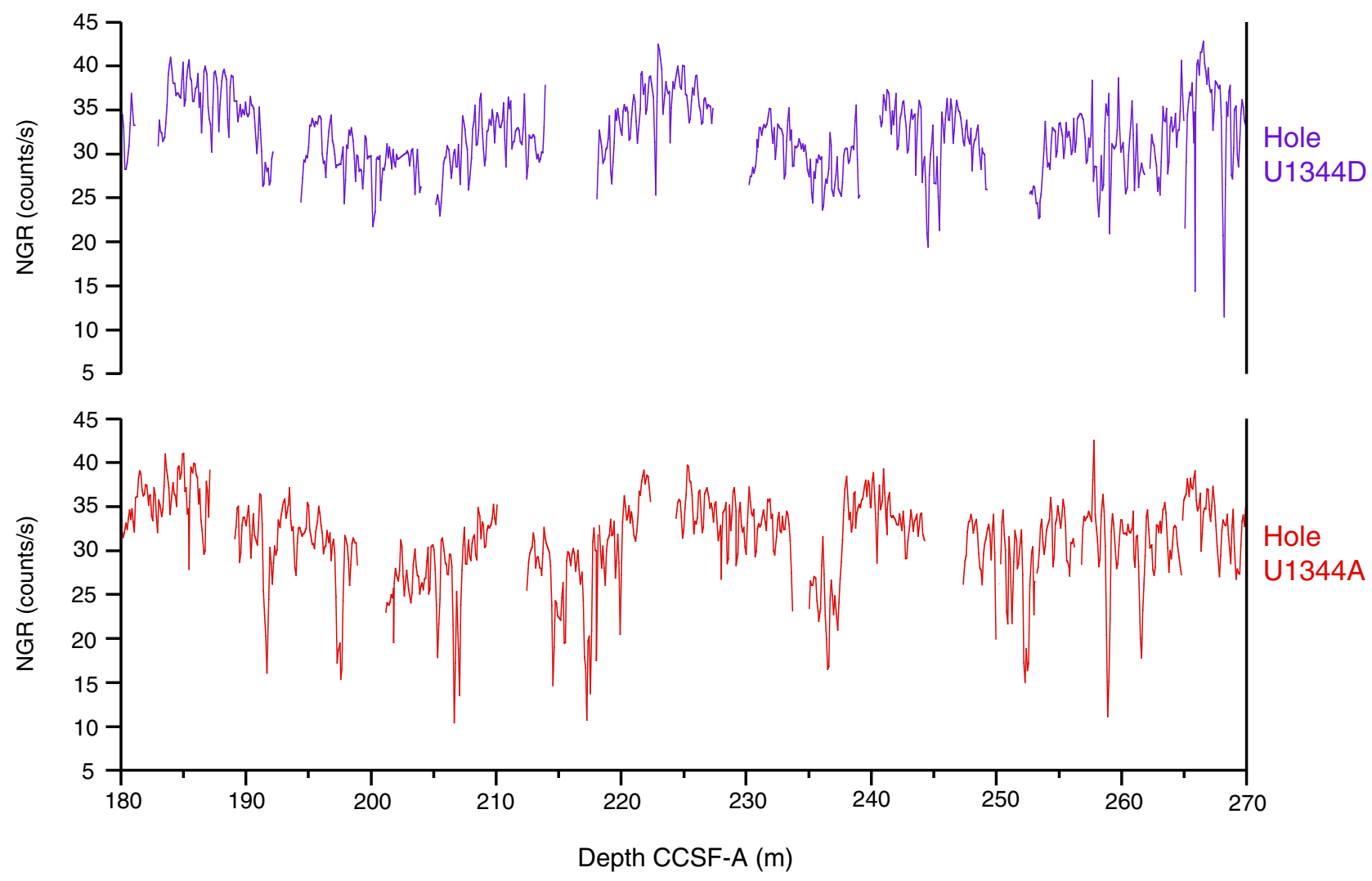
Figure F37 (continued). D. 270-360 m CCSF-A.

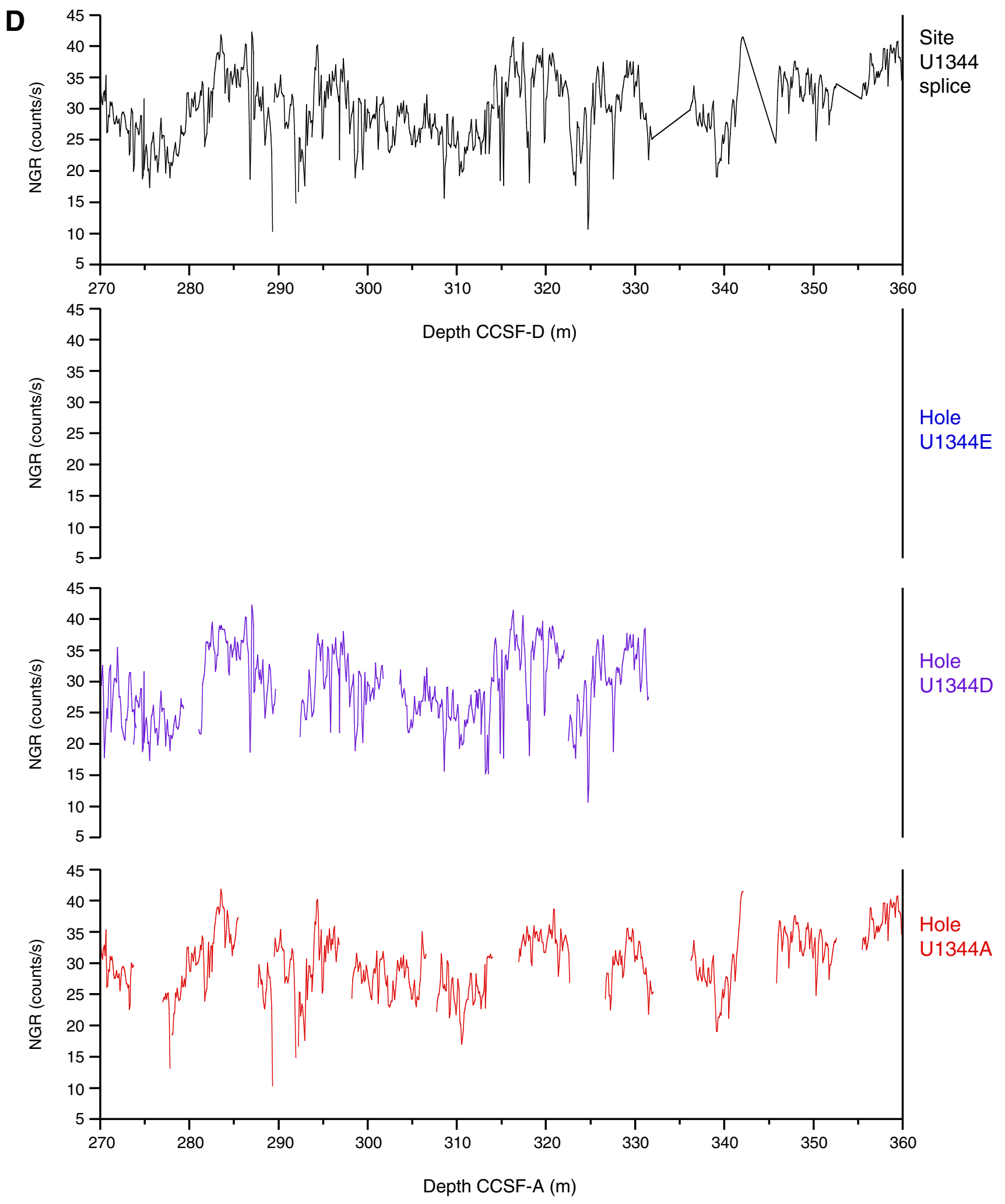


Figure F38. Color reflectance parameter $b^{*}$ data collected with the SHMSL for the interval of the continuous splice and the spliced record, Site U1344. No color reflectance data are available for Hole U1344C. For the splice record (top panel), depth on the CCSF-D scale is equivalent to depth on the CCSF-A scale. A. 0-90 m CCSF-A. (Continued on next three pages.)

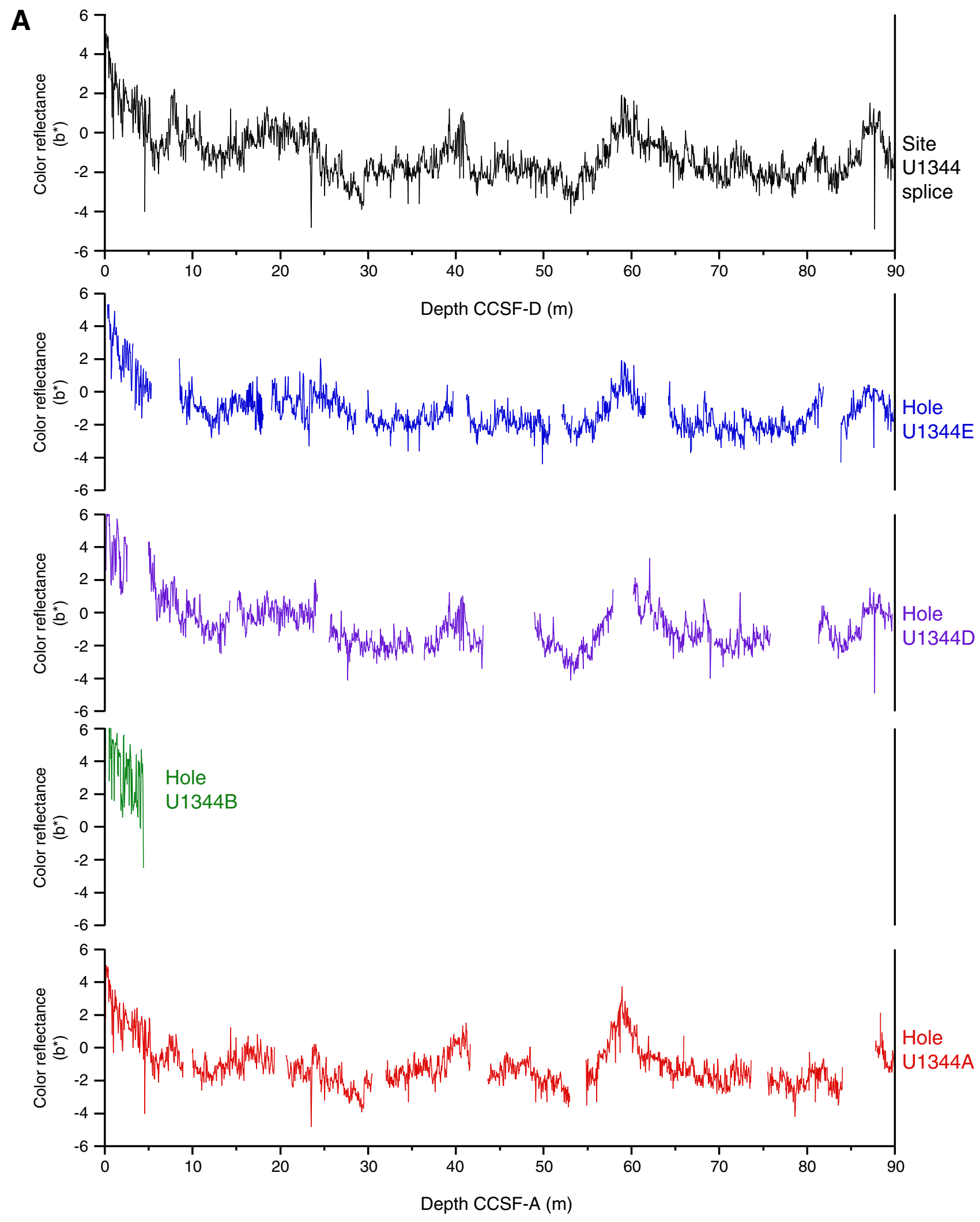


Figure F38 (continued). B. 90-180 m CCSF-A. (Continued on next page.)
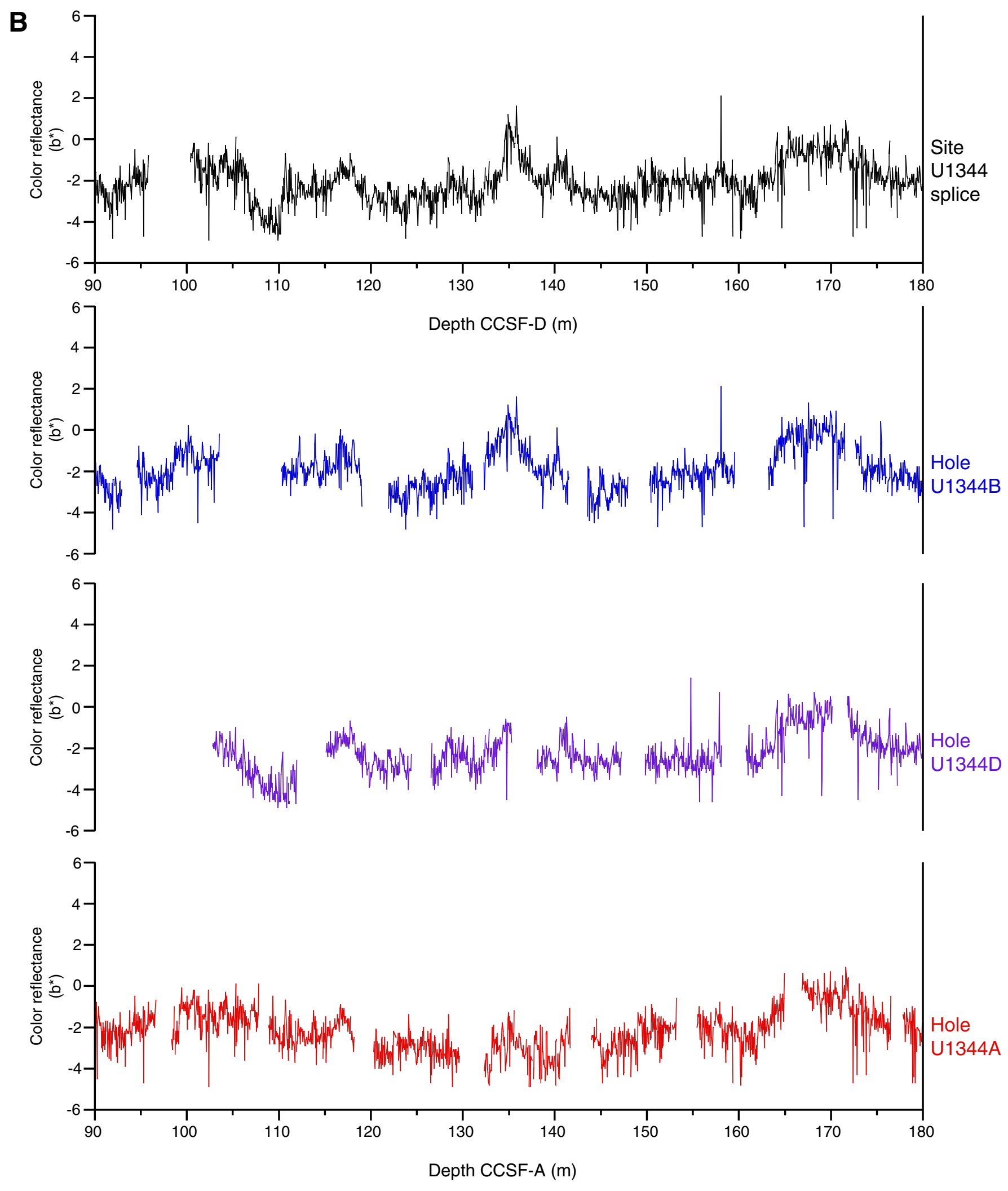
Figure F38 (continued). C. 180-270 m CCSF-A. (Continued on next page.)

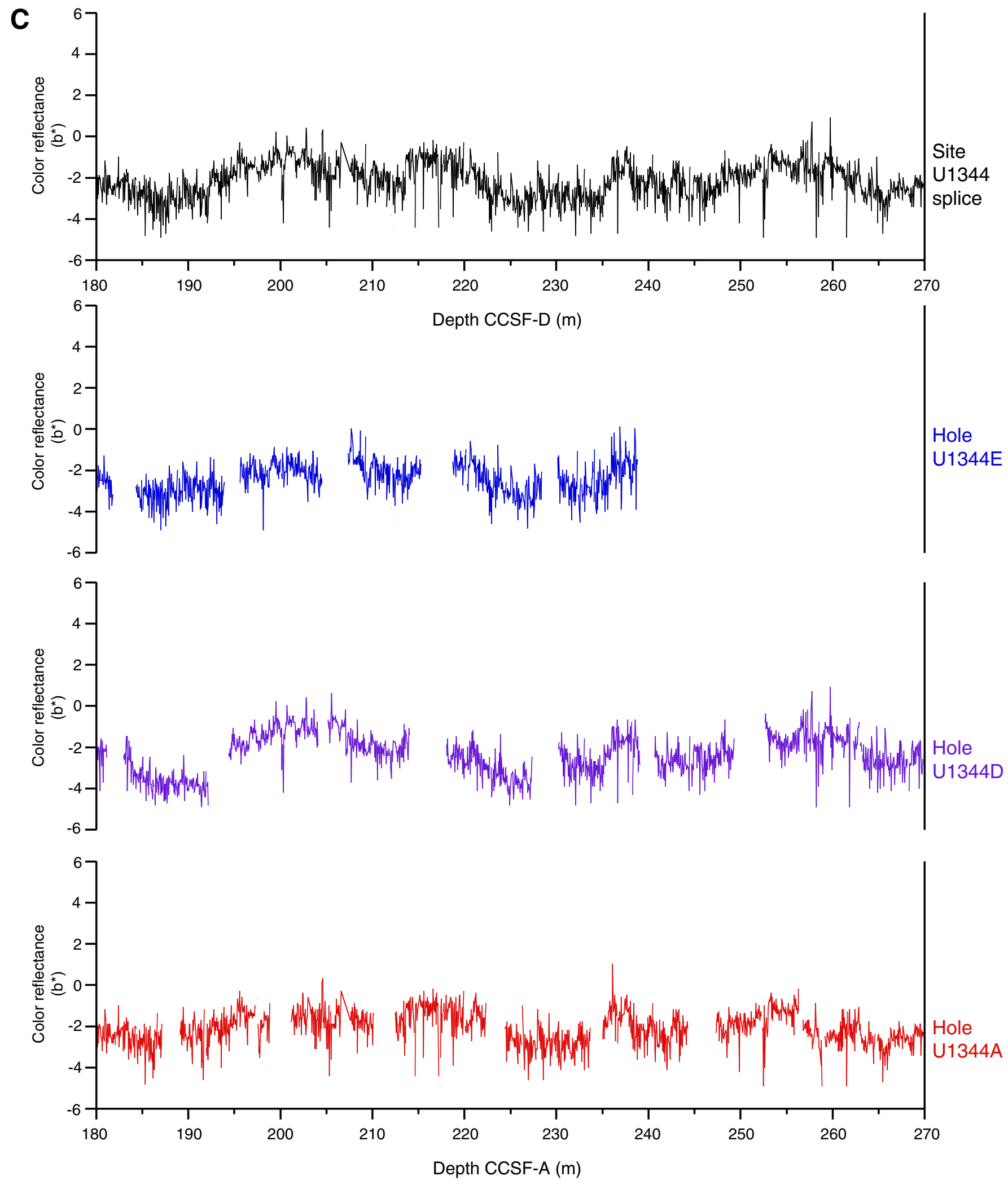


Figure F38 (continued). D. 270-360 m CCSF-A.
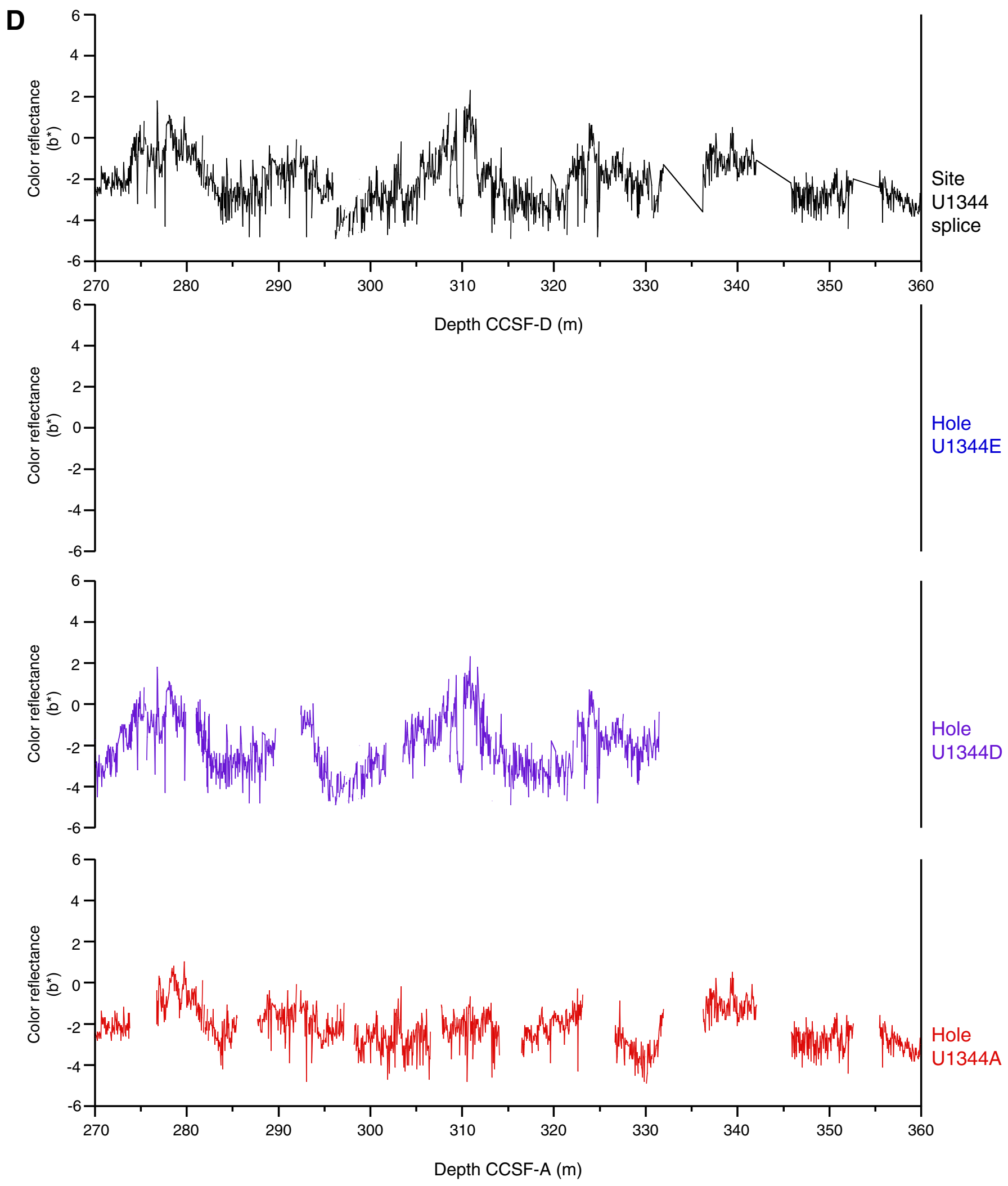

radiation (NGR) (smoothed), and color reflectance parameter $b^{*}$ (smoothed) vs. splice composite depth for the spliced interval of Site U1344.
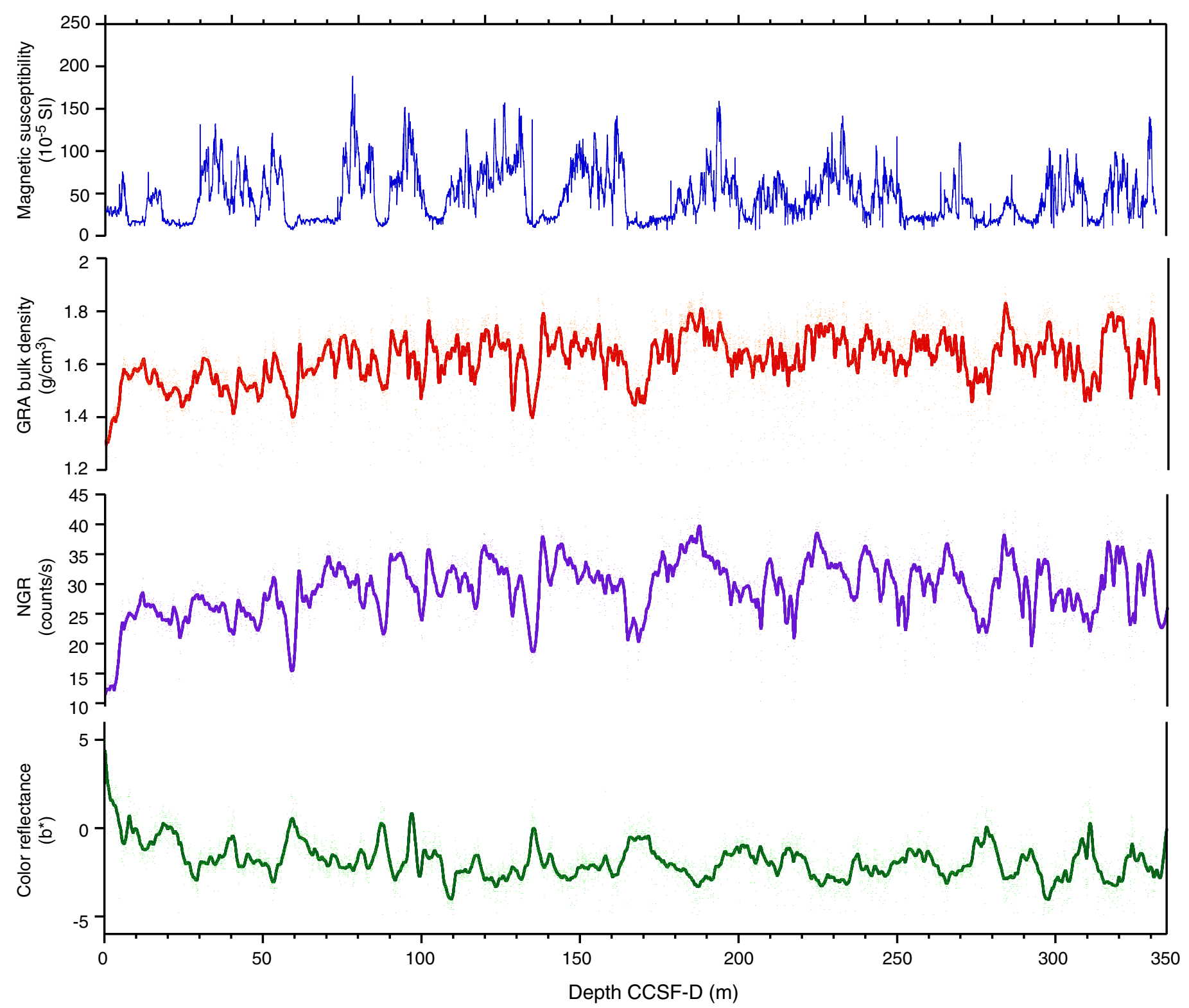
Figure F40. A. Mbsf vs. composite (CCSF-A) depth in the splice, Site U1344. B. Growth of cumulative depth offset $(\mathrm{m})$ vs. mbsf in the splice. The affine growth factor is 1.18 .

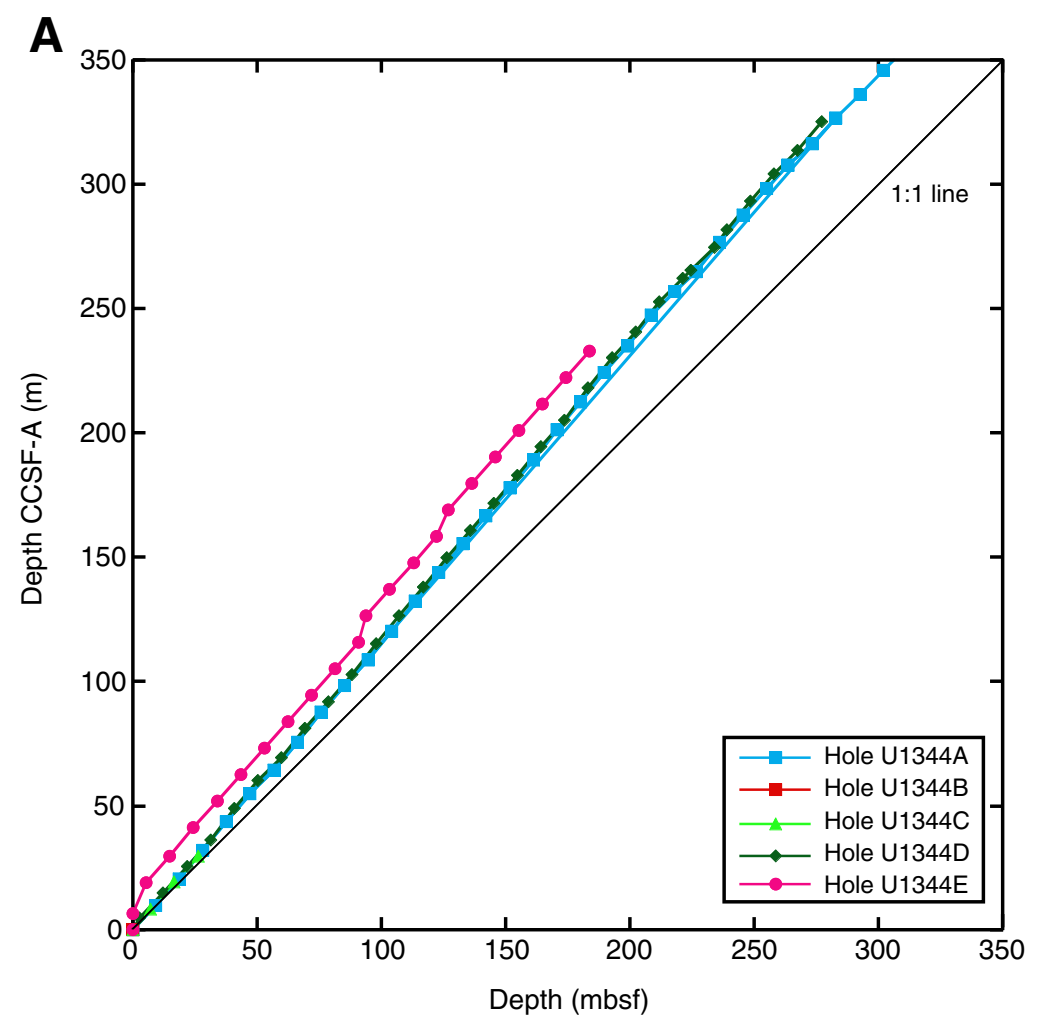

B

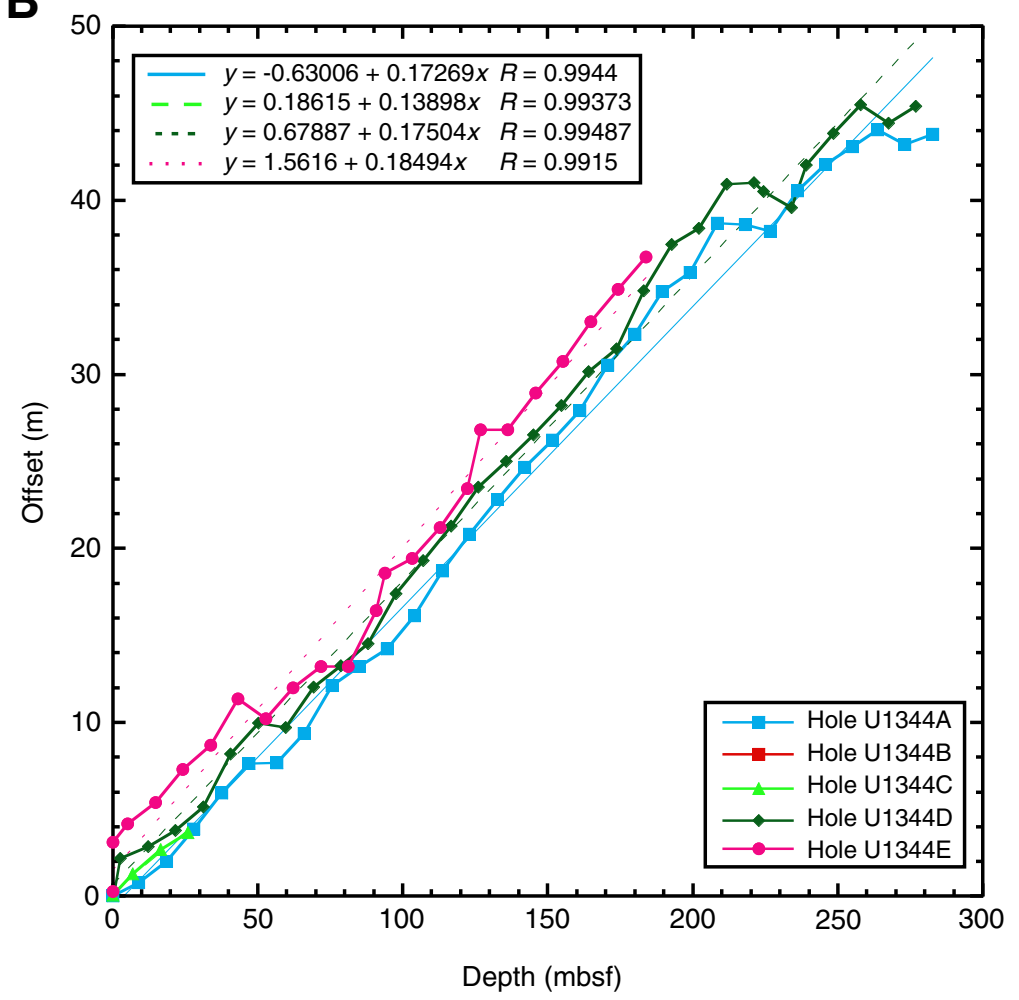


Figure F41. Summary of logs recorded by the triple combo tool string, Hole U1344A. HLDS = Hostile Environment Litho-Density Sonde, $\mathrm{c} / \mathrm{s}=$ counts per second, MAD = moisture and density core data, GRA = gamma ray attenuation bulk density core track measurements, IDPH = deep induction phasor-processed resistivity, $\mathrm{IMPH}=$ medium induction phasor-processed resistivity, SFLU $=$ spherically focused resistivity.

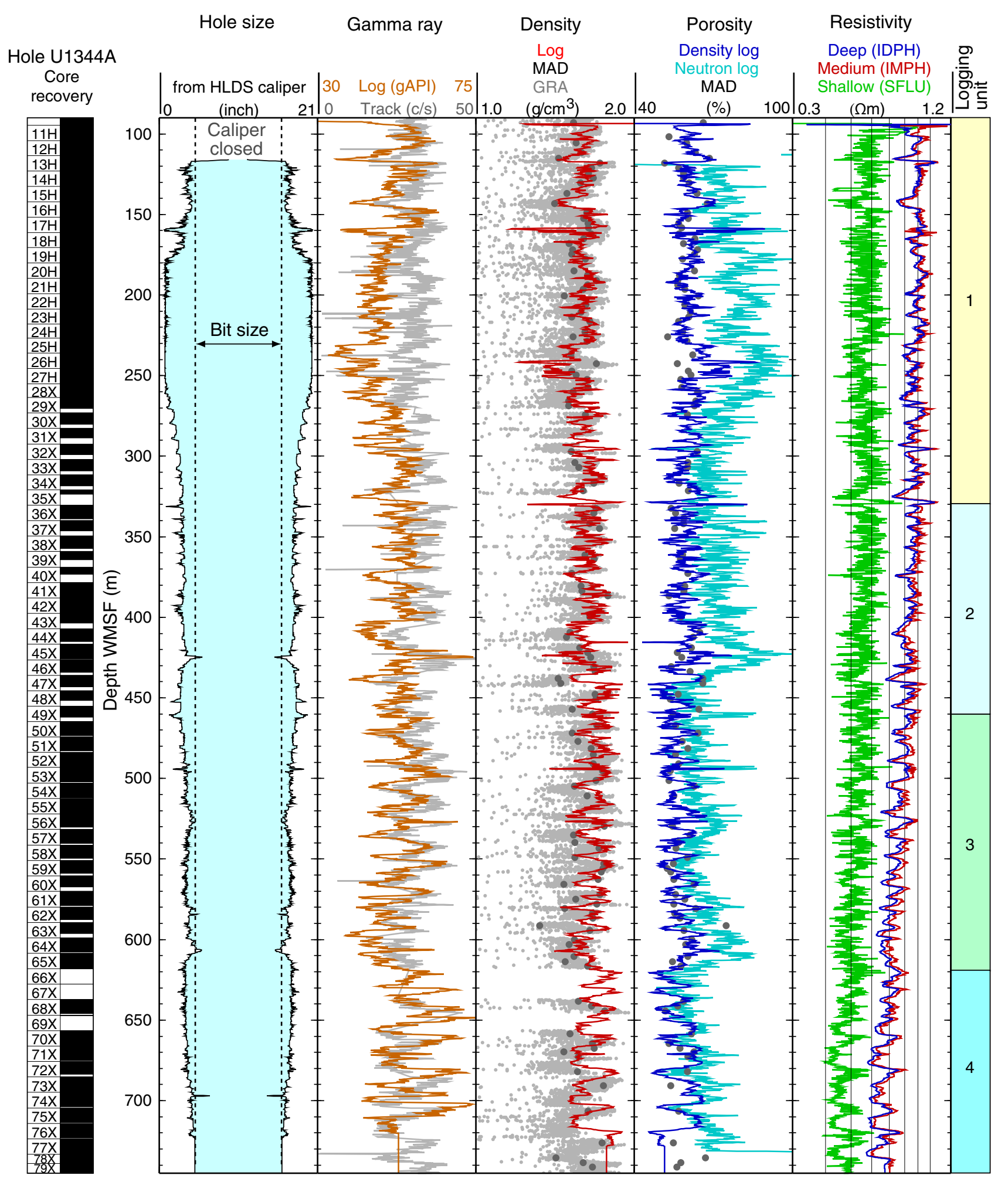


Figure F42. Summary of logs recorded by the Formation MicroScanner (FMS)-sonic tool string in Hole U1344A during the downlog and the second uphole pass. Hole size is calculated by the two orthogonal calipers of the FMS (C1 and C2). High waveform coherence (red in the velocity tracks) is a measure of the reliability of the slowness/time coherence algorithm used to derive compressional $\left(V_{\mathrm{P}}\right)$ and shear $\left(V_{\mathrm{S}}\right)$ velocities from the monopole and lower dipole (LD) sonic waveforms, respectively. Waveform amplitude is shown to display any amplitude anomaly that could indicate the occurrence of gas hydrate. None was detected. WF = sonic waveform, TC = gamma ray log from the triple combo, down = recorded during the downlog.

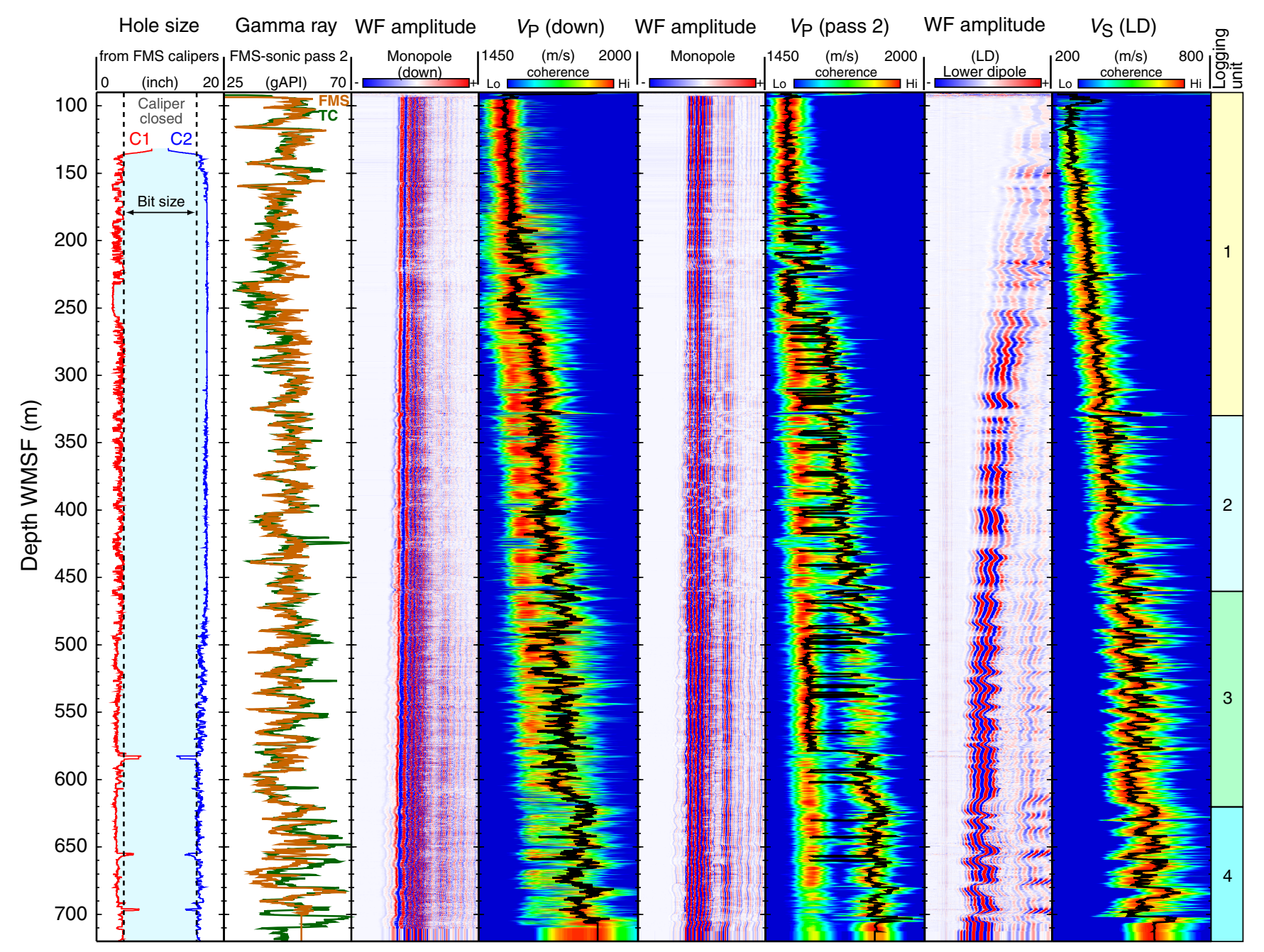


Figure F43. Summary of spectral natural gamma ray measurements, Hole U1344A. CGR = computed gamma ray (gamma ray without the uranium contribution), GR = total gamma ray. The area between the two curves shows the contribution of uranium, a common indicator of organic content.

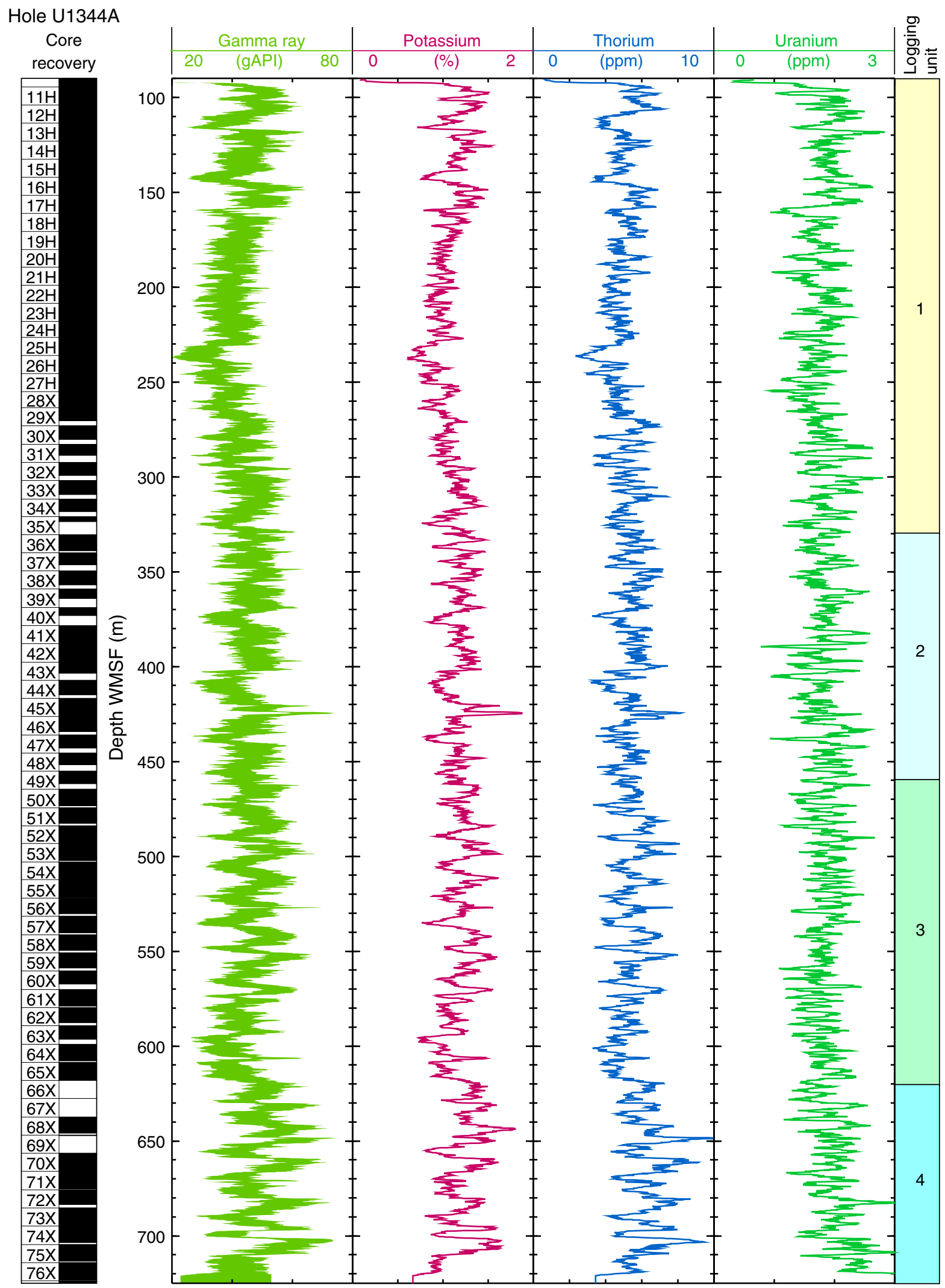


Figure F44. Comparison of the synthetic seismogram calculated from the density and $V_{\mathrm{p}}$ logs in Hole U1344A and MCS Line Stk3-7 (Sakamoto et al., 2005) across Site U1344. The gamma ray log is shown as a reference to the other logs and the logging units. The $V_{\mathrm{p}} \log$ was recorded during the downlog.

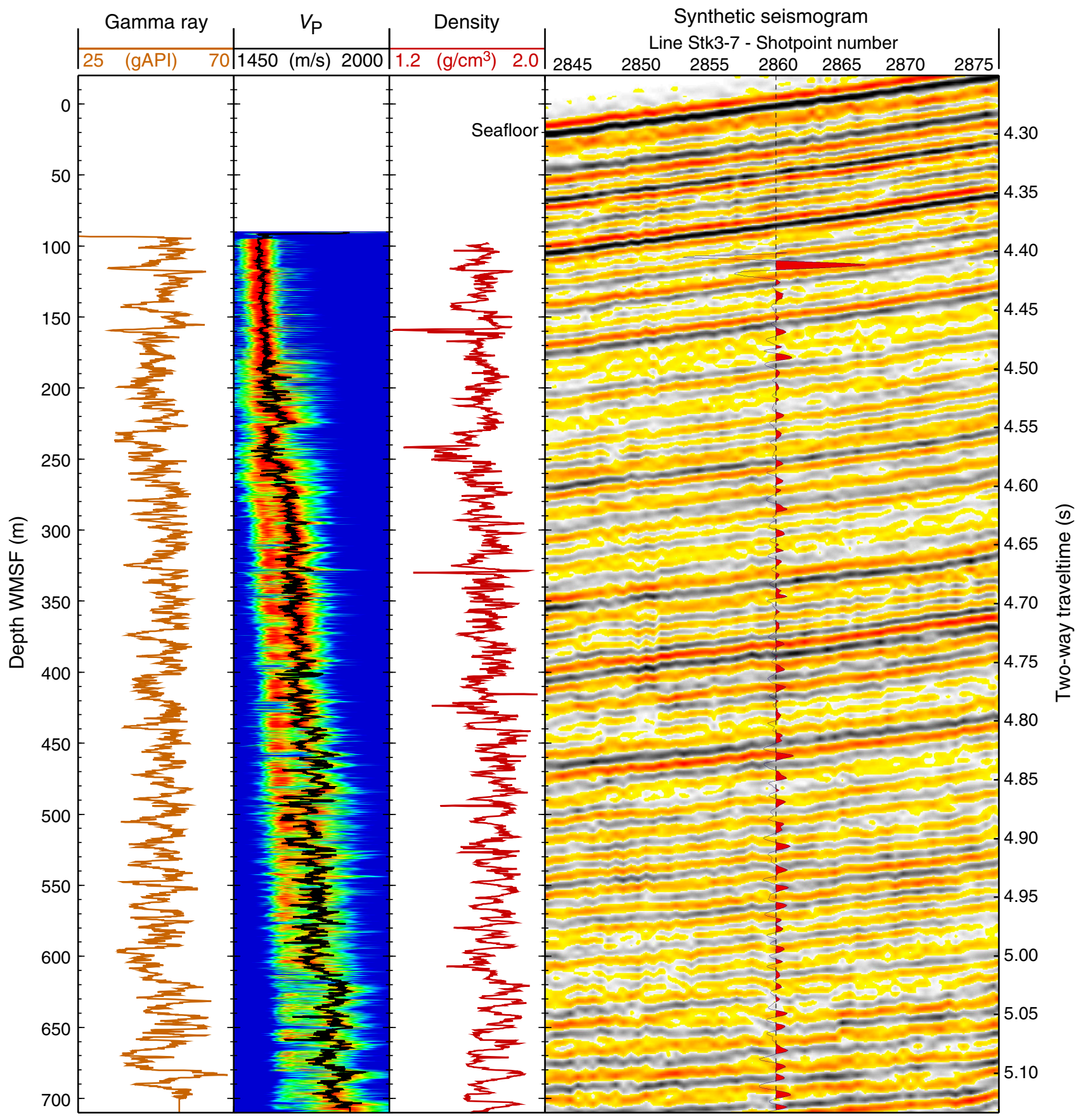


Figure F45. Correlation between FMS electrical images and core observations in each of the four logging units. A. Black sulfide speckles (Sections 323-U1344A-18H-3 and 18H-4), recognizable as black conductive features in the FMS images. B. Authigenic carbonates and a fine sand from logging Unit 2 (Section 323-U1344A-37X-4). These appear resistive in the images. C. White carbonate pebbles (Section 323-U1344A-61X-4). These occur in several places in logging Unit 3 and appear as bright resistive features in the FMS images. D. $3 \mathrm{~m}$ section of the $20 \mathrm{~m}$ interval not recovered at the top of logging Unit 4. The image shows conductive (dark) layers dipping steeply to the north, overlaying more conductive speckles similar to the sulfide speckles observed in several places in the hole. The contrast in some of the core images has been enhanced. Note the differences in vertical scale between images.

A

$m$

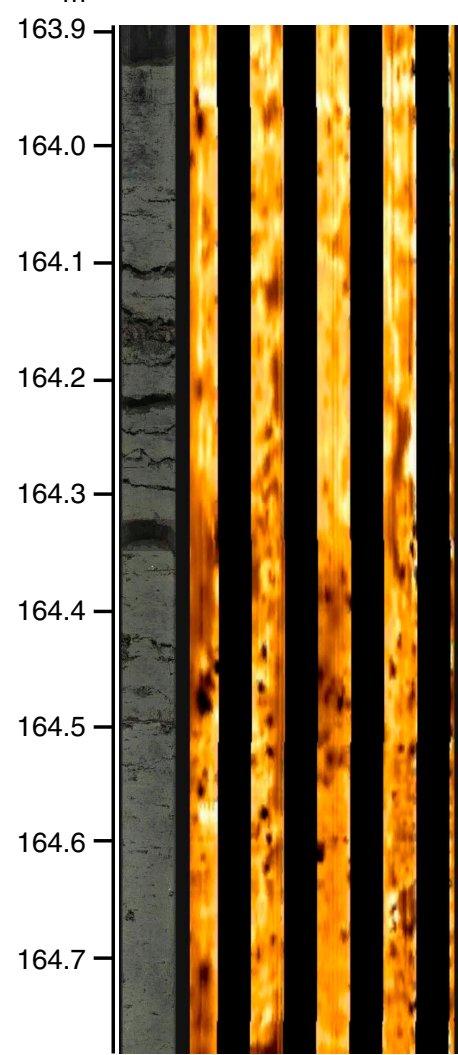

B

$\mathrm{m}$

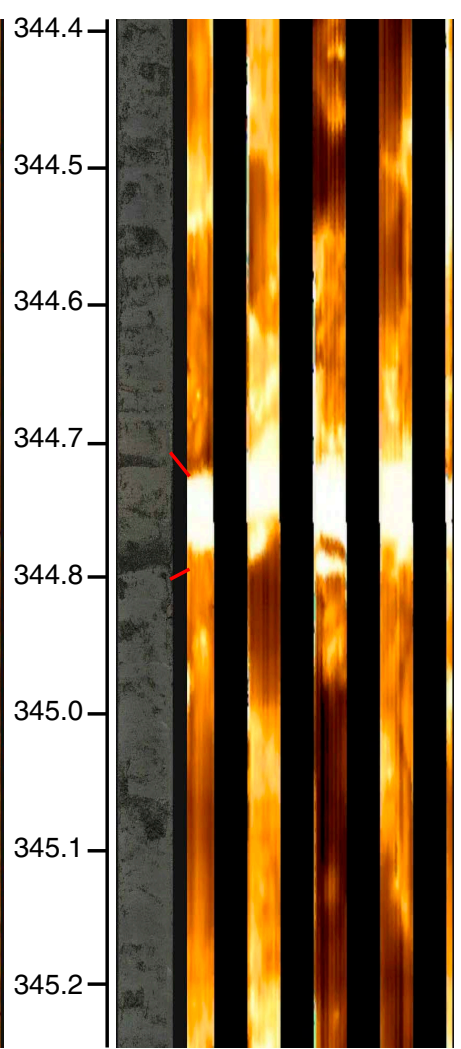

C

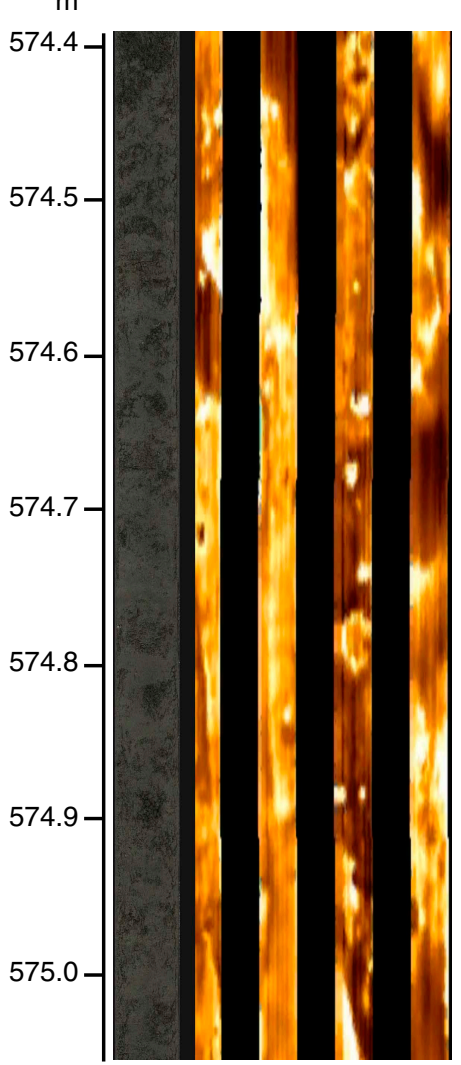

D

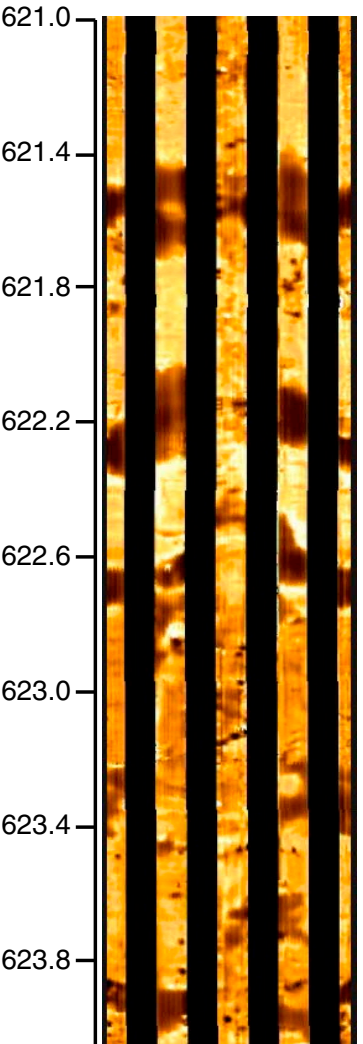


Figure F46. A. Records of the penetrations and temperature decays of the APCT-3 probe, Hole U1344A. B. Summary of temperature measurements.
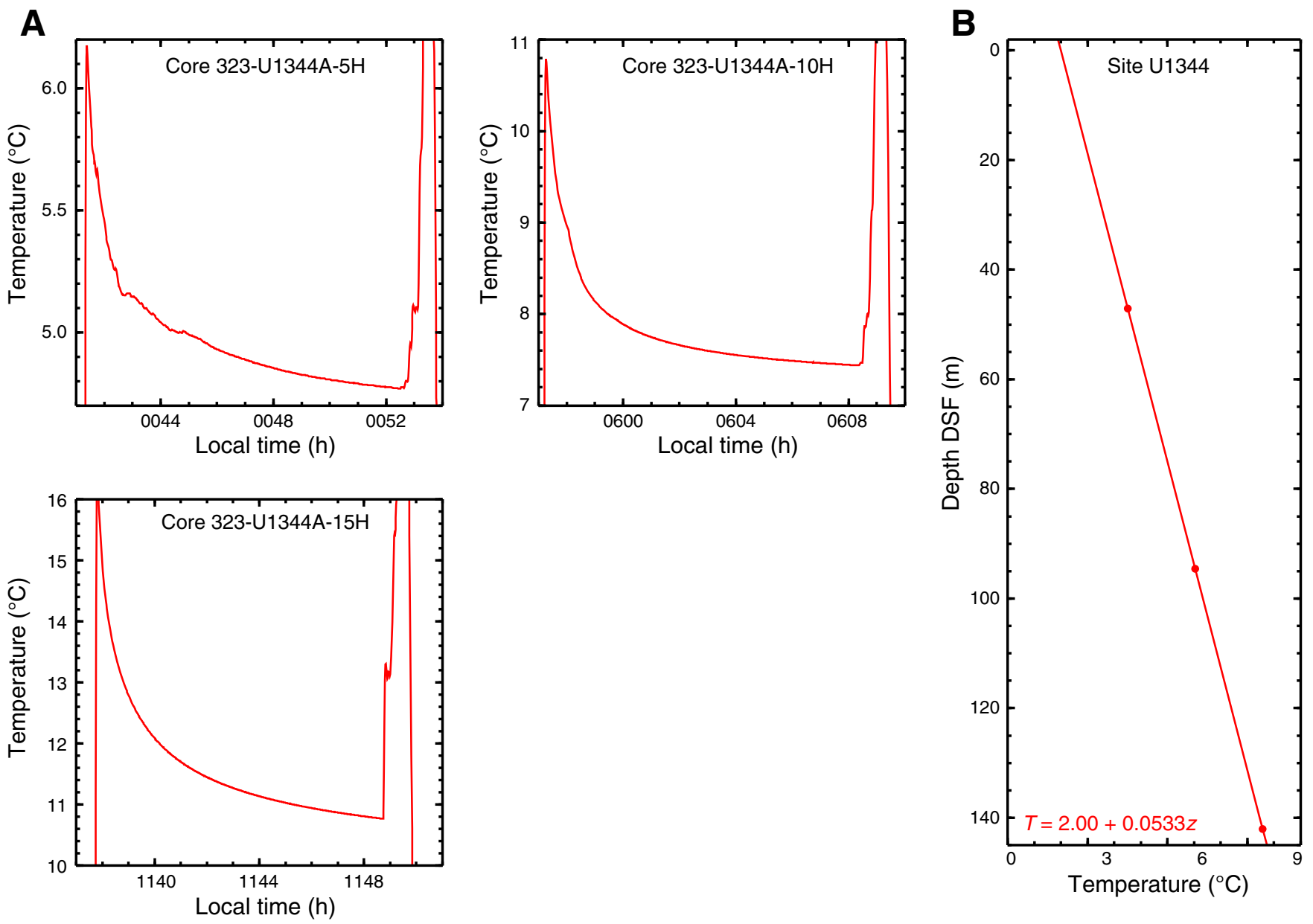
Table T1. Coring summary, Holes U1344A, U1344B, U1344C, U1344D, and U1344E. (See table notes.) (Continued on next three pages.)

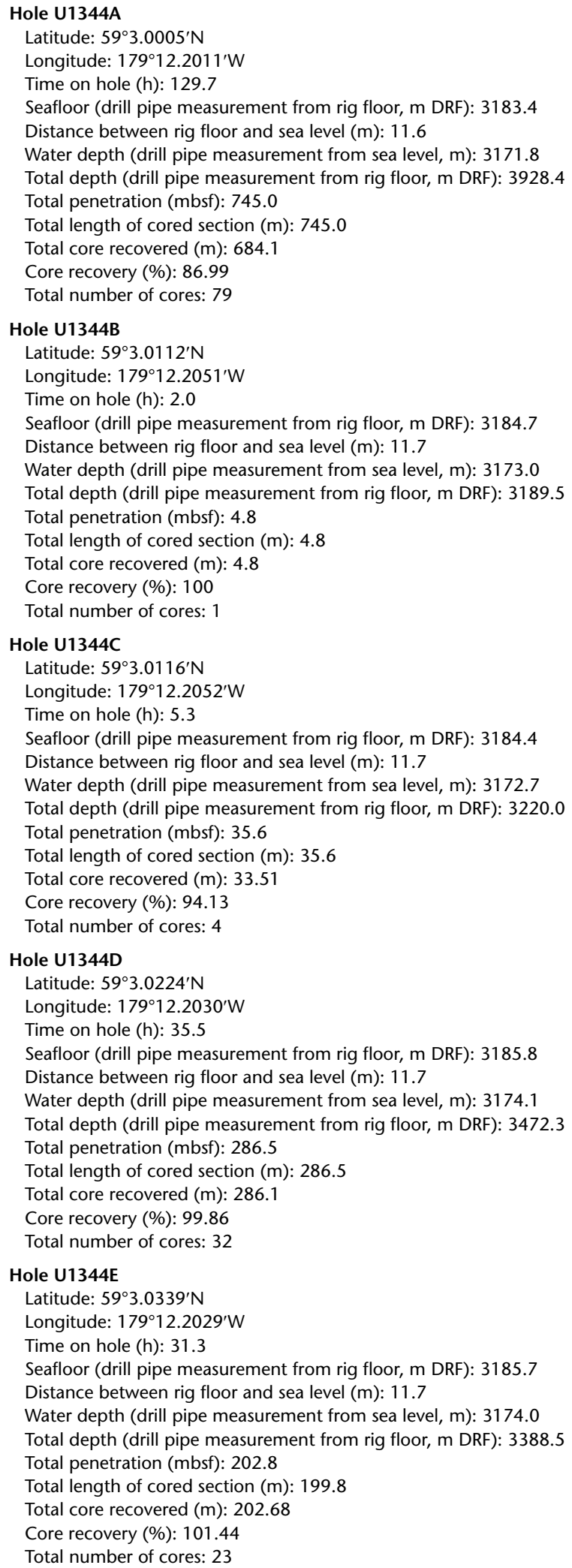


Table T1 (continued). (Continued on next page.)

\begin{tabular}{|c|c|c|c|c|c|c|c|c|}
\hline \multirow[b]{2}{*}{ Core } & \multirow{2}{*}{$\begin{array}{l}\text { Date } \\
(2009)\end{array}$} & \multirow{2}{*}{$\begin{array}{l}\text { UTC } \\
\text { (h) }\end{array}$} & \multicolumn{2}{|c|}{ Depth DSF (m) } & \multicolumn{2}{|c|}{ Length $(\mathrm{m})$} & \multirow{2}{*}{$\begin{array}{c}\text { Recovery } \\
\text { (\%) }\end{array}$} & \multirow[b]{2}{*}{ Comments } \\
\hline & & & Top & Bottom & Cored & Recovered & & \\
\hline \multicolumn{9}{|c|}{ 323-U1344A- } \\
\hline $1 \mathrm{H}$ & 14 Aug & 2100 & 0.0 & 9.1 & 9.1 & 9.14 & 100 & Oriented nonmagnetic barrel \\
\hline $2 \mathrm{H}$ & 14 Aug & 2205 & 9.1 & 18.6 & 9.5 & 9.65 & 102 & Oriented nonmagnetic barrel \\
\hline $3 \mathrm{H}$ & 14 Aug & 2305 & 18.6 & 28.1 & 9.5 & 10.12 & 107 & Oriented nonmagnetic barrel \\
\hline $4 \mathrm{H}$ & 15 Aug & 0005 & 28.1 & 37.6 & 9.5 & 10.12 & 107 & Oriented nonmagnetic barrel \\
\hline $5 \mathrm{H}$ & 15 Aug & 0120 & 37.6 & 47.1 & 9.5 & 10.01 & 105 & APCT, oriented nonmagnetic barrel \\
\hline $6 \mathrm{H}$ & 15 Aug & 0220 & 47.1 & 56.6 & 9.5 & 10.19 & 107 & Oriented nonmagnetic barrel \\
\hline $7 \mathrm{H}$ & 15 Aug & 0315 & 56.6 & 66.1 & 9.5 & 10.08 & 106 & Oriented nonmagnetic barrel \\
\hline $8 \mathrm{H}$ & 15 Aug & 0415 & 66.1 & 75.6 & 9.5 & 9.22 & 97 & Oriented nonmagnetic barrel \\
\hline $9 \mathrm{H}$ & 15 Aug & 0520 & 75.6 & 85.1 & 9.5 & 9.61 & 101 & Oriented nonmagnetic barrel \\
\hline $10 \mathrm{H}$ & 15 Aug & 0640 & 85.1 & 94.6 & 9.5 & 10.09 & 106 & APCT, oriented nonmagnetic barrel \\
\hline $11 \mathrm{H}$ & 15 Aug & 0740 & 94.6 & 104.1 & 9.5 & 9.86 & 104 & Oriented nonmagnetic barrel \\
\hline $12 \mathrm{H}$ & 15 Aug & 0840 & 104.1 & 113.6 & 9.5 & 9.86 & 104 & Oriented nonmagnetic barrel \\
\hline $13 \mathrm{H}$ & 15 Aug & 0945 & 113.6 & 123.1 & 9.5 & 9.89 & 104 & Oriented nonmagnetic barrel \\
\hline $14 \mathrm{H}$ & 15 Aug & 1050 & 123.1 & 132.6 & 9.5 & 9.79 & 103 & Oriented nonmagnetic barrel \\
\hline $15 \mathrm{H}$ & 15 Aug & 1215 & 132.6 & 142.1 & 9.5 & 9.85 & 104 & APCT, oriented nonmagnetic barrel \\
\hline $16 \mathrm{H}$ & 15 Aug & 1320 & 142.1 & 151.6 & 9.5 & 10.13 & 107 & Oriented nonmagnetic barrel \\
\hline $17 \mathrm{H}$ & 15 Aug & 1425 & 151.6 & 161.1 & 9.5 & 9.67 & 102 & Oriented nonmagnetic barrel \\
\hline $18 \mathrm{H}$ & 15 Aug & 1530 & 161.1 & 170.6 & 9.5 & 10.24 & 108 & Oriented nonmagnetic barrel \\
\hline $19 \mathrm{H}$ & 15 Aug & 1635 & 170.6 & 180.1 & 9.5 & 9.57 & 101 & Oriented nonmagnetic barrel \\
\hline $20 \mathrm{H}$ & 15 Aug & 1735 & 180.1 & 189.6 & 9.5 & 10.30 & 108 & Oriented nonmagnetic barrel \\
\hline $21 \mathrm{H}$ & 15 Aug & 1850 & 189.6 & 199.1 & 9.5 & 9.68 & 102 & Oriented nonmagnetic barrel \\
\hline $22 \mathrm{H}$ & 15 Aug & 1955 & 199.1 & 208.6 & 9.5 & 9.73 & 102 & Oriented nonmagnetic barrel \\
\hline $23 \mathrm{H}$ & 15 Aug & 2100 & 208.6 & 218.1 & 9.5 & 9.51 & 100 & Oriented nonmagnetic barrel \\
\hline $24 \mathrm{H}$ & 15 Aug & 2200 & 218.1 & 226.6 & 8.5 & 8.57 & 101 & Nonmagnetic barrel \\
\hline $25 \mathrm{H}$ & 15 Aug & 2315 & 226.6 & 236.1 & 9.5 & 9.50 & 100 & Nonmagnetic barrel \\
\hline $26 \mathrm{H}$ & 16 Aug & 0040 & 236.1 & 245.6 & 9.5 & 9.39 & 99 & Nonmagnetic barrel \\
\hline $27 \mathrm{H}$ & 16 Aug & 0230 & 245.6 & 255.1 & 9.5 & 10.23 & 108 & Steel barrel \\
\hline $28 \mathrm{X}$ & 16 Aug & 0400 & 255.1 & 263.6 & 8.5 & 8.73 & 103 & Steel barrel \\
\hline $29 x$ & 16 Aug & 0500 & 263.6 & 273.2 & 9.6 & 6.75 & 70 & Steel barrel \\
\hline $30 x$ & 16 Aug & 0600 & 273.2 & 282.8 & 9.6 & 7.11 & 74 & Steel barrel \\
\hline $31 x$ & 16 Aug & 0700 & 282.8 & 292.4 & 9.6 & 5.78 & 60 & Steel barrel \\
\hline $32 x$ & 16 Aug & 0805 & 292.4 & 302.0 & 9.6 & 6.77 & 71 & Steel barrel \\
\hline $33 x$ & 16 Aug & 0900 & 302.0 & 311.6 & 9.6 & 7.23 & 75 & Steel barrel \\
\hline $34 X$ & 16 Aug & 1000 & 311.6 & 320.9 & 9.3 & 6.81 & 73 & Steel barrel \\
\hline $35 x$ & 16 Aug & 1105 & 320.9 & 330.4 & 9.5 & 2.67 & 28 & Steel barrel \\
\hline $36 x$ & 16 Aug & 1205 & 330.4 & 340.0 & 9.6 & 8.49 & 88 & Steel barrel \\
\hline $37 X$ & 16 Aug & 1310 & 340.0 & 349.6 & 9.6 & 6.38 & 66 & Steel barrel \\
\hline $38 x$ & 16 Aug & 1415 & 349.6 & 359.2 & 9.6 & 7.48 & 78 & Steel barrel \\
\hline $39 x$ & 16 Aug & 1520 & 359.2 & 368.8 & 9.6 & 5.03 & 52 & Steel barrel \\
\hline $40 x$ & 16 Aug & 1625 & 368.8 & 378.5 & 9.7 & 4.39 & 45 & Steel barrel \\
\hline $41 x$ & 16 Aug & 1720 & 378.5 & 388.0 & 9.5 & 9.47 & 100 & Steel barrel \\
\hline $42 x$ & 16 Aug & 1825 & 388.0 & 397.6 & 9.6 & 9.51 & 99 & Steel barrel \\
\hline $43 x$ & 16 Aug & 1920 & 397.6 & 407.2 & 9.6 & 5.96 & 62 & Steel barrel \\
\hline $44 X$ & 16 Aug & 2015 & 407.2 & 416.8 & 9.6 & 7.78 & 81 & Steel barrel \\
\hline $45 x$ & 16 Aug & 2120 & 416.8 & 426.4 & 9.6 & 9.13 & 95 & Steel barrel \\
\hline $46 \mathrm{X}$ & 16 Aug & 2225 & 426.4 & 436.0 & 9.6 & 7.70 & 80 & Steel barrel \\
\hline $47 x$ & 16 Aug & 2330 & 436.0 & 445.6 & 9.6 & 7.02 & 73 & Steel barrel \\
\hline $48 \mathrm{X}$ & 17 Aug & 0035 & 445.6 & 455.1 & 9.5 & 6.09 & 64 & Steel barrel \\
\hline $49 x$ & 17 Aug & 0135 & 455.1 & 464.7 & 9.6 & 6.75 & 70 & Steel barrel \\
\hline $50 x$ & 17 Aug & 0735 & 464.7 & 474.4 & 9.7 & 8.79 & 91 & Steel barrel \\
\hline $51 x$ & 17 Aug & 0940 & 474.4 & 483.9 & 9.5 & 8.27 & 87 & Steel barrel \\
\hline $52 X$ & 17 Aug & 1050 & 483.9 & 493.2 & 9.3 & 9.30 & 100 & Steel barrel \\
\hline $53 x$ & 17 Aug & 1200 & 493.2 & 502.9 & 9.7 & 8.93 & 92 & Steel barrel \\
\hline $54 \mathrm{X}$ & 17 Aug & 1310 & 502.9 & 512.4 & 9.5 & 9.06 & 95 & Steel barrel \\
\hline $55 x$ & 17 Aug & 1420 & 512.4 & 522.0 & 9.6 & 9.40 & 98 & Steel barrel \\
\hline $56 \mathrm{X}$ & 17 Aug & 1525 & 522.0 & 531.7 & 9.7 & 8.31 & 86 & Steel barrel \\
\hline $57 X$ & 17 Aug & 1715 & 531.7 & 541.3 & 9.6 & 8.58 & 89 & Steel barrel \\
\hline $58 \mathrm{X}$ & 17 Aug & 1825 & 541.3 & 550.9 & 9.6 & 8.27 & 86 & Steel barrel \\
\hline $59 x$ & 17 Aug & 1930 & 550.9 & 560.5 & 9.6 & 7.89 & 82 & Steel barrel \\
\hline $60 x$ & 17 Aug & 2110 & 560.5 & 570.1 & 9.6 & 6.92 & 72 & Steel barrel \\
\hline $61 X$ & 17 Aug & 2215 & 570.1 & 579.8 & 9.7 & 8.80 & 91 & Steel barrel \\
\hline $62 X$ & 17 Aug & 2330 & 579.8 & 589.4 & 9.6 & 7.81 & 81 & Steel barrel \\
\hline $63 x$ & 18 Aug & 0030 & 589.4 & 599.0 & 9.6 & 6.89 & 72 & Steel barrel \\
\hline $64 X$ & 18 Aug & 0140 & 599.0 & 608.5 & 9.5 & 8.73 & 92 & Steel barrel \\
\hline $65 x$ & 18 Aug & 0250 & 608.5 & 618.1 & 9.6 & 9.58 & 100 & Steel barrel \\
\hline $66 \mathrm{X}$ & 18 Aug & 0415 & 618.1 & 627.7 & 9.6 & 0.00 & 0 & Steel barrel \\
\hline $67 X$ & 18 Aug & 0535 & 627.7 & 637.3 & 9.6 & 0.00 & 0 & Steel barrel \\
\hline $68 \mathrm{X}$ & 18 Aug & 0650 & 637.3 & 646.9 & 9.6 & 8.70 & 91 & Steel barrel \\
\hline
\end{tabular}


Table T1 (continued). (Continued on next page.)

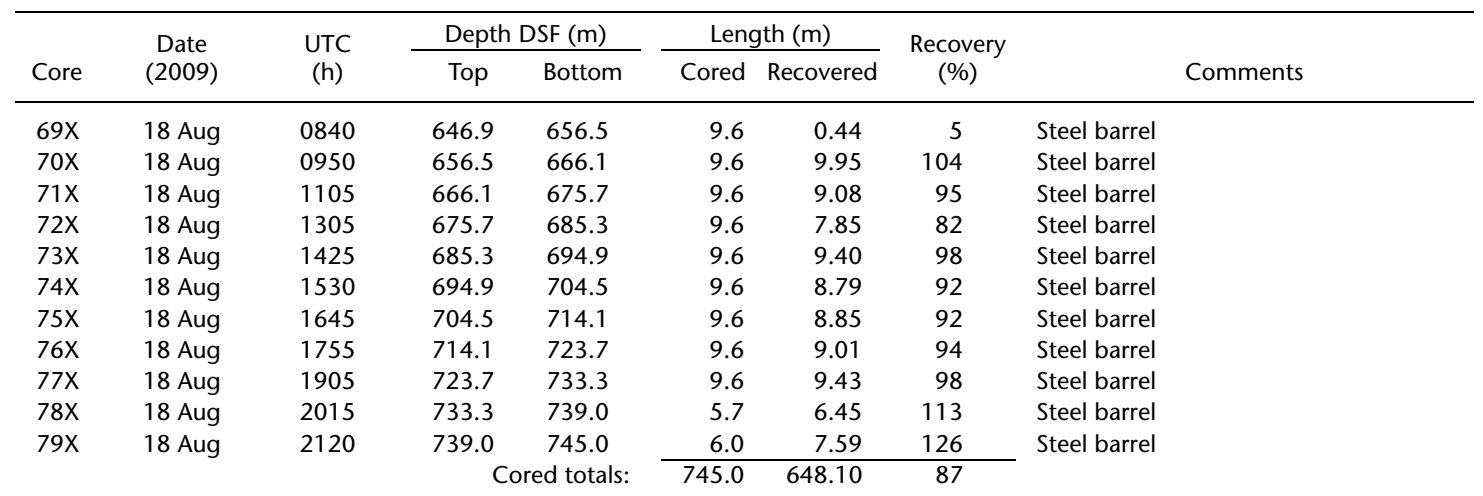

323-U1344B-

$\begin{array}{ccc}1 \mathrm{H} & 20 \text { Aug } & 0110 \\ & & \\ 323-U 1344 \mathrm{C}- & \\ 1 \mathrm{H} & 20 \mathrm{Aug} & 0230 \\ 2 \mathrm{H} & 20 \mathrm{Aug} & 0335 \\ 3 \mathrm{H} & 20 \mathrm{Aug} & 0430 \\ 4 \mathrm{H} & 20 \mathrm{Aug} & 0530\end{array}$

323-U1344D-

\begin{tabular}{|c|c|c|c|c|}
\hline $1 \mathrm{H}$ & 20 Aug & 0705 & 0.0 & 2.7 \\
\hline $2 \mathrm{H}$ & 20 Aug & 0805 & 2.7 & 12.2 \\
\hline $3 \mathrm{H}$ & 20 Aug & 0905 & 12.2 & 21.7 \\
\hline $4 \mathrm{H}$ & 20 Aug & 1000 & 21.7 & 31.2 \\
\hline $5 \mathrm{H}$ & 20 Aug & 1135 & 31.2 & 40.7 \\
\hline $6 \mathrm{H}$ & 20 Aug & 1220 & 40.7 & 50.2 \\
\hline 7H & 20 Aug & 1305 & 50.2 & 59.7 \\
\hline $8 \mathrm{H}$ & 20 Aug & 1350 & 59.7 & 69.2 \\
\hline $9 \mathrm{H}$ & 20 Aug & 1435 & 69.2 & 78.7 \\
\hline $10 \mathrm{H}$ & 20 Aug & 1530 & 78.7 & 88.2 \\
\hline $11 \mathrm{H}$ & 20 Aug & 1630 & 88.2 & 97.7 \\
\hline $12 \mathrm{H}$ & 20 Aug & 1725 & 97.7 & 107.2 \\
\hline $13 \mathrm{H}$ & 20 Aug & 1820 & 107.2 & 116.7 \\
\hline $14 \mathrm{H}$ & 20 Aug & 1915 & 116.7 & 126.2 \\
\hline $15 \mathrm{H}$ & 20 Aug & 2005 & 126.2 & 135.7 \\
\hline $16 \mathrm{H}$ & 20 Aug & 2055 & 135.7 & 145.2 \\
\hline $17 \mathrm{H}$ & 20 Aug & 2150 & 145.2 & 154.7 \\
\hline $18 \mathrm{H}$ & 20 Aug & 2235 & 154.7 & 164.2 \\
\hline $19 \mathrm{H}$ & 20 Aug & 2335 & 164.2 & 173.7 \\
\hline $20 \mathrm{H}$ & 21 Aug & 0040 & 173.7 & 183.2 \\
\hline $21 \mathrm{H}$ & $21 \mathrm{Aug}$ & 0135 & 183.2 & 192.7 \\
\hline $22 \mathrm{H}$ & 21 Aug & 0235 & 192.7 & 202.2 \\
\hline $23 \mathrm{H}$ & 21 Aug & 0330 & 202.2 & 211.7 \\
\hline $24 \mathrm{H}$ & 21 Aug & 0430 & 211.7 & 221.2 \\
\hline $25 \mathrm{H}$ & 21 Aug & 0540 & 221.2 & 224.5 \\
\hline $26 \mathrm{H}$ & 21 Aug & 0715 & 224.5 & 234.0 \\
\hline $27 \mathrm{H}$ & 21 Aug & 0920 & 234.0 & 239.0 \\
\hline $28 \mathrm{H}$ & 21 Aug & 1020 & 239.0 & 248.5 \\
\hline $29 \mathrm{H}$ & 21 Aug & 1125 & 248.5 & 258.0 \\
\hline $30 \mathrm{H}$ & 21 Aug & 1310 & 258.0 & 267.5 \\
\hline $31 \mathrm{H}$ & 21 Aug & 1420 & 267.5 & 277.0 \\
\hline $32 \mathrm{H}$ & 21 Aug & 1535 & 277.0 & 286.5 \\
\hline
\end{tabular}

$$
\begin{aligned}
& 0.04 .8 \\
& \text { Cored totals: }
\end{aligned}
$$

\begin{tabular}{lll}
4.8 & 4.44 & 92 \\
\hline 4.8 & 4.44 & 92
\end{tabular}

Nonmagnetic barrel, split liner

$$
\begin{array}{rr}
0.0 & 7.1 \\
7.1 & 16.6 \\
16.6 & 26.1 \\
26.1 & 35.6
\end{array}
$$
Cored totals:

\begin{tabular}{rrr}
7.1 & 7.12 & 100 \\
9.5 & 7.14 & 75 \\
9.5 & 9.80 & 103 \\
9.5 & 9.45 & 99 \\
\hline 35.6 & 33.51 & 94
\end{tabular}

Nonmagnetic barrel

\begin{tabular}{|c|c|c|c|c|c|c|c|c|}
\hline $1 \mathrm{H}$ & 21 Aug & 1910 & 0.0 & 5.3 & 5.3 & 5.34 & 101 & Nonmagnetic barrel \\
\hline $2 \mathrm{H}$ & 21 Aug & 2010 & 5.3 & 14.8 & 9.5 & 9.72 & 102 & Nonmagnetic barrel \\
\hline $3 \mathrm{H}$ & 21 Aug & 2100 & 14.8 & 24.3 & 9.5 & 10.05 & 106 & Nonmagnetic barrel \\
\hline $4 \mathrm{H}$ & 21 Aug & 2145 & 24.3 & 33.8 & 9.5 & 10.38 & 109 & Nonmagnetic barrel \\
\hline $5 \mathrm{H}$ & 21 Aug & 2245 & 33.8 & 43.3 & 9.5 & 10.02 & 105 & Nonmagnetic barrel \\
\hline $6 \mathrm{H}$ & 21 Aug & 2340 & 43.3 & 52.8 & 9.5 & 10.08 & 106 & Nonmagnetic barrel \\
\hline $7 \mathrm{H}$ & 22 Aug & 0035 & 52.8 & 62.3 & 9.5 & 9.30 & 98 & Nonmagnetic barrel \\
\hline $8 \mathrm{H}$ & 22 Aug & 0135 & 62.3 & 71.8 & 9.5 & 9.75 & 103 & Nonmagnetic barrel \\
\hline $9 \mathrm{H}$ & 22 Aug & 0230 & 71.8 & 81.3 & 9.5 & 9.57 & 101 & Nonmagnetic barrel \\
\hline $10 \mathrm{H}$ & 22 Aug & 0330 & 81.3 & 90.8 & 9.5 & 9.55 & 101 & Nonmagnetic barrel \\
\hline 11D & & & & rilled & 8 to & $8 \mathrm{~m} \mathrm{DS}$ & 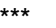 & \\
\hline
\end{tabular}
Nonmagnetic barrel Nonmagnetic barrel Nonmagnetic barrel

323-U1344E- 
Table T1 (continued).

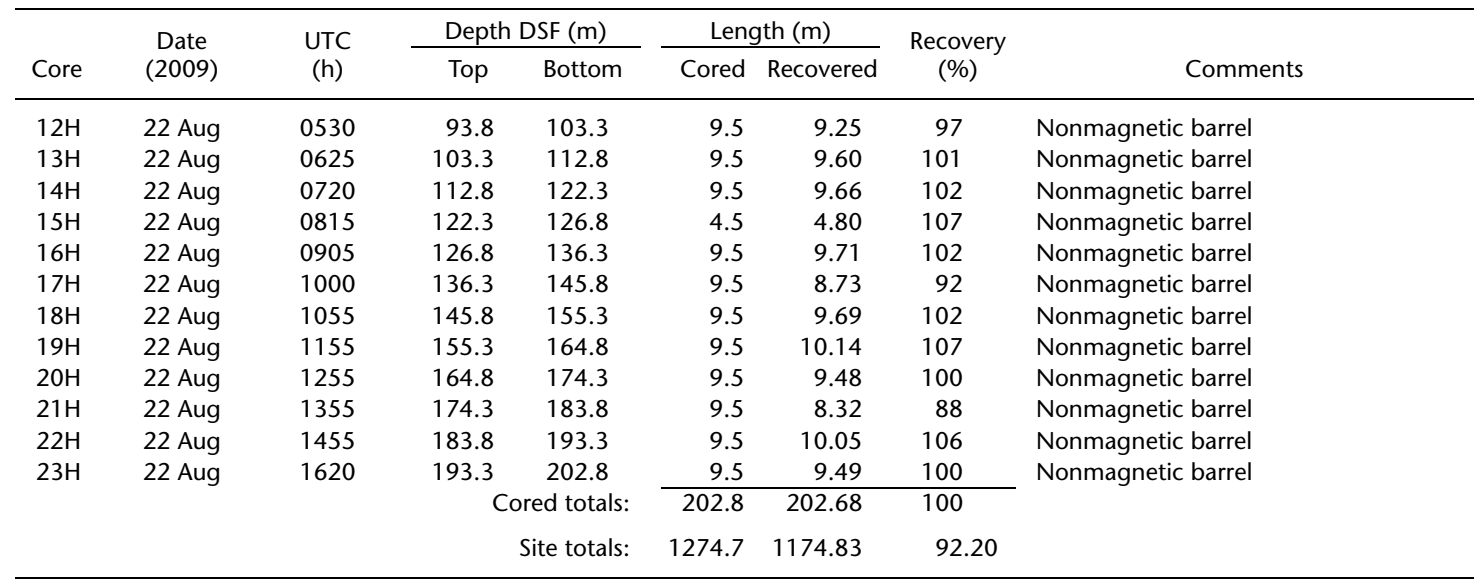

Notes: $\mathrm{DRF}=$ drilling depth below rig floor, $\mathrm{mbsf}=$ meters below seafloor, DSF $=$ drilling depth below seafloor. APCT $=$ advanced piston corer temperature tool. UTC $=$ Universal Time Coordinated.

Table T2. Datum events of radiolarians, diatoms, silicoflagellates, dinoflagellates, and ebridians, Holes U1344A, U1344D, and U1344E. (See table notes.)

\begin{tabular}{|c|c|c|c|c|c|c|c|c|}
\hline \multirow[b]{2}{*}{ Datum event } & \multirow[b]{2}{*}{ Taxon } & \multirow[b]{2}{*}{$\begin{array}{l}\text { Age } \\
(\mathrm{Ma})\end{array}$} & \multicolumn{3}{|c|}{ Depth (mbsf) } & \multicolumn{3}{|c|}{ Depth CCSF-A (m) } \\
\hline & & & $\begin{array}{l}\text { Hole } \\
\text { U1344A }\end{array}$ & $\begin{array}{l}\text { Hole } \\
\text { U1344D }\end{array}$ & $\begin{array}{l}\text { Hole } \\
\text { U1344E }\end{array}$ & $\begin{array}{c}\text { Hole } \\
\text { U1344A }\end{array}$ & $\begin{array}{c}\text { Hole } \\
\text { U1344D }\end{array}$ & $\begin{array}{l}\text { Hole } \\
\text { U1344E }\end{array}$ \\
\hline LO Lychnocanoma nipponica sakaii & Radiolarian & 0.05 & 23.7 & 26.6 & 19.9 & 25.1 & 30.0 & 23.6 \\
\hline LO Distephanus octonarius & Silicoflagellate & $0.21-0.3$ & - & 102.6 & - & - & 118.6 & - \\
\hline LO Spongodiscus sp. & Radiolarian & $0.28-0.32$ & 109.2 & 102.6 & 108.0 & 124.4 & 118.6 & 125.5 \\
\hline LO Axoprunum acquilonium & Radiolarian & $0.25-0.43$ & 118.7 & 93.2 & 117.7 & 136.1 & - & 136.7 \\
\hline LO Proboscia curvirostris & Diatom & 0.3 & 118.7 & 93.2 & 117.7 & 136.1 & 107.1 & 136.7 \\
\hline LO Thalassiosira jouseae & Diatom & 0.3 & 118.7 & 102.6 & 97.0 & 136.1 & 118.6 & 111.8 \\
\hline LO Stylatractus universus & Radiolarian & $0.41-0.51$ & - & 150.3 & 150.3 & - & 176.0 & 177.1 \\
\hline LO Dictyocha subarctios & Silicoflagellate & $0.6-0.8$ & 275.3 & 237.4 & - & 320.1 & 278.1 & - \\
\hline LCO Actinocyclus oculatus & Diatom & 0.9 & 409.3 & - & - & 455.7 & - & - \\
\hline LO Eucyrtidium matuyamai & Radiolarian & $0.9-1.5$ & 409.3 & - & - & 455.7 & - & - \\
\hline LO Filisphaera filifera & Dinoflagellate & $1.4-1.7$ & 462.6 & - & - & 509.0 & - & - \\
\hline FCO Proboscia curvirostris & Diatom & $1.7-2.0$ & 526.1 & - & - & 572.5 & - & - \\
\hline LO Stephanopyxis horridus & Diatom & $1.7-1.9$ & 592.0 & - & - & 638.4 & - & - \\
\hline LO Ammodochium rectangulare & Ebridian & 1.9 & 731.4 & - & - & 777.9 & - & - \\
\hline
\end{tabular}

Notes: For first occurrences (FO), the depth was estimated as the midpoint between the depths at which the species was first observed and the depth of the next sample below. For last occurrences (LO), the depth was estimated as the midpoint between the depth at which the species was last observed and the depth of the next sample above. $\mathrm{LCO}=$ last common occurrence, $\mathrm{FCO}=$ first common occurrence, $-=$ not applicable. 
Table T3. Calcareous nannofossil range chart, Holes U1344A, U1344B, U1344C, U1344D, and U1344E. (See table notes.) (Continued on next three pages.)

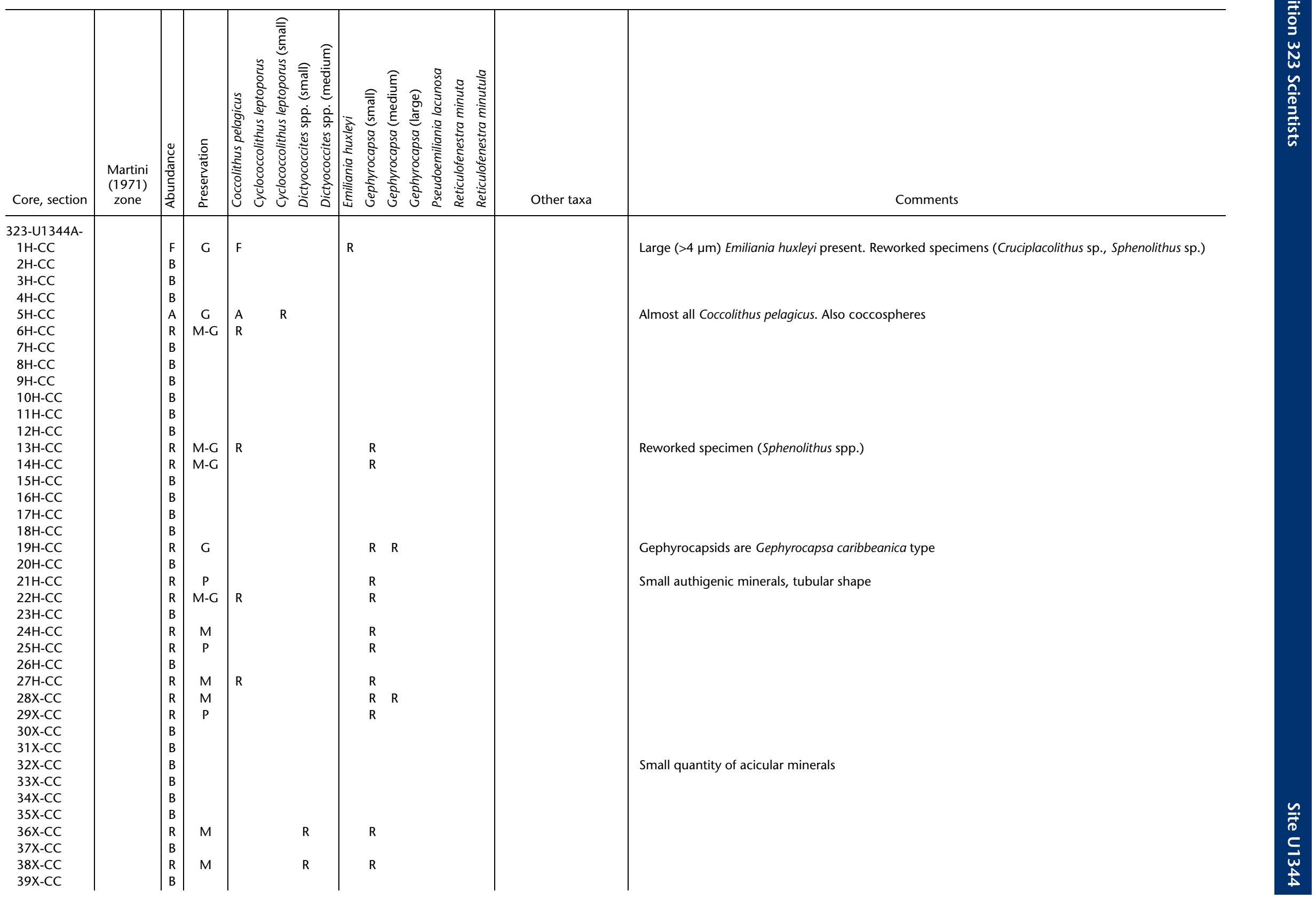




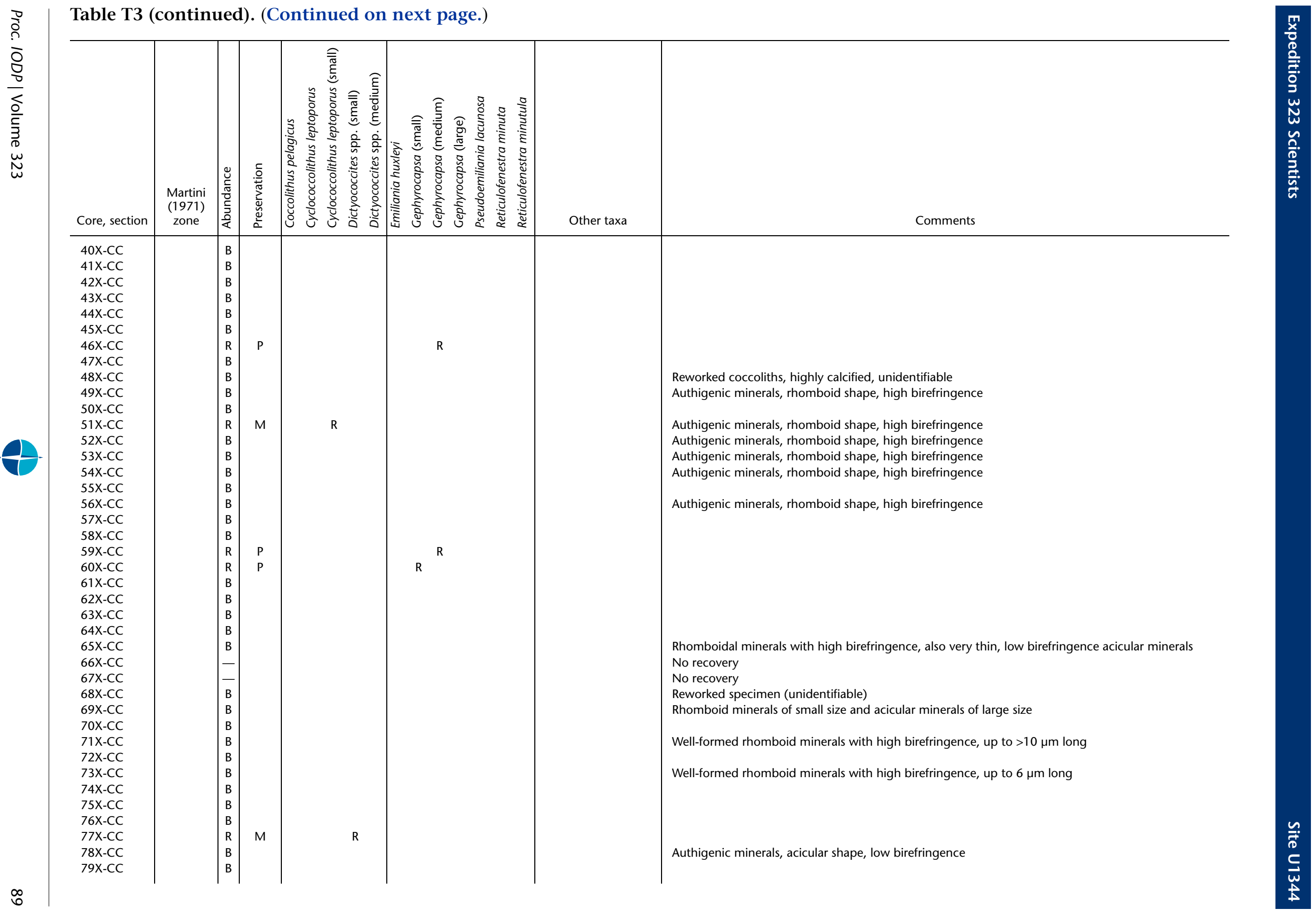




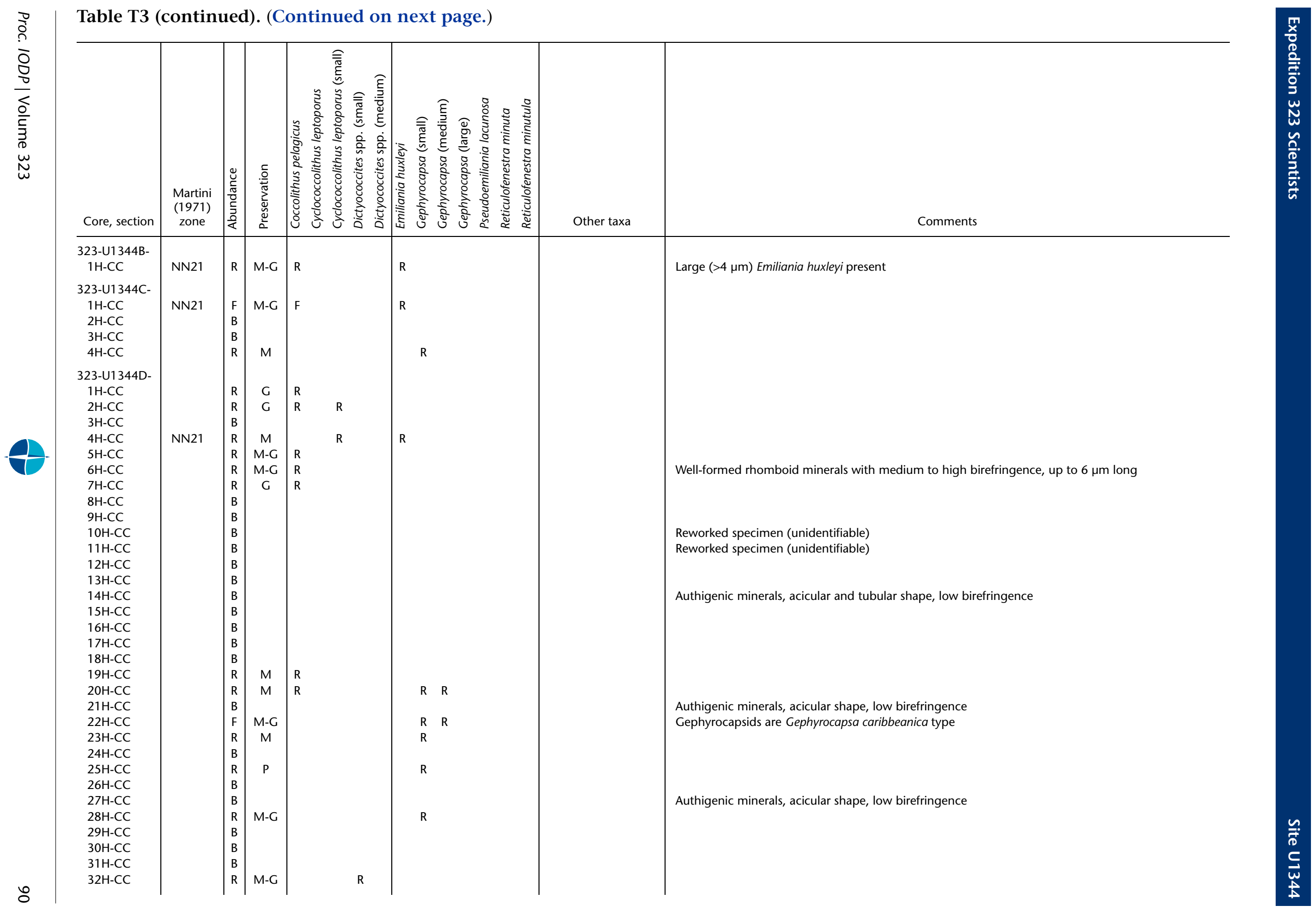




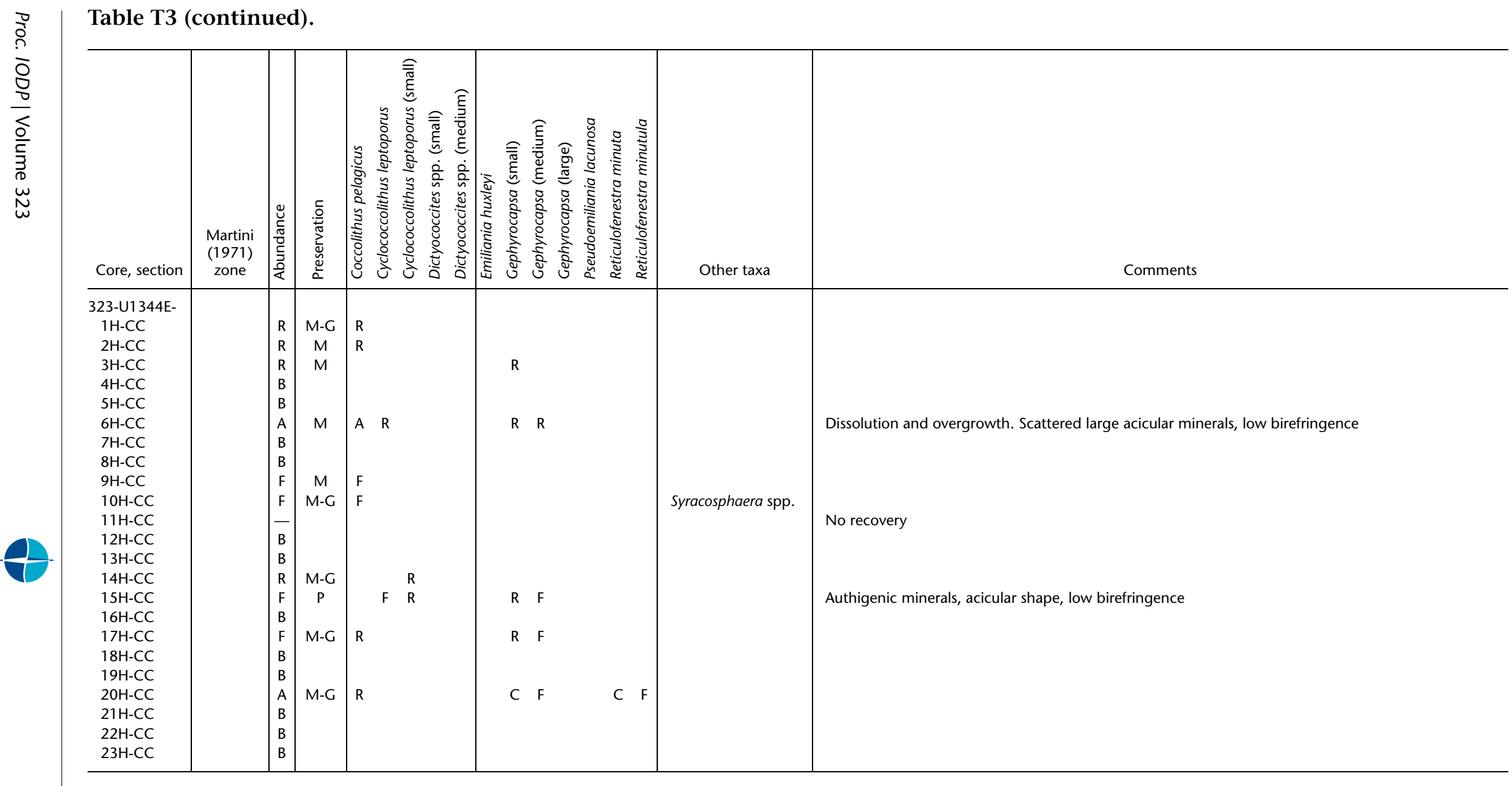

Notes: Abundance: $\mathrm{A}=$ abundant, $\mathrm{C}=$ common, $\mathrm{F}=$ few, $\mathrm{R}=$ rare $\mathrm{B}=$ barren. Preservation: $\mathrm{G}=$ good, $\mathrm{M}=$ moderate, $\mathrm{P}=$ poor. 
Table T4. Planktonic foraminifer range chart, Holes U1344A, U1344B, U1344C, U1344D, and U1344E. (See table notes.) (Continued on next two pages.)

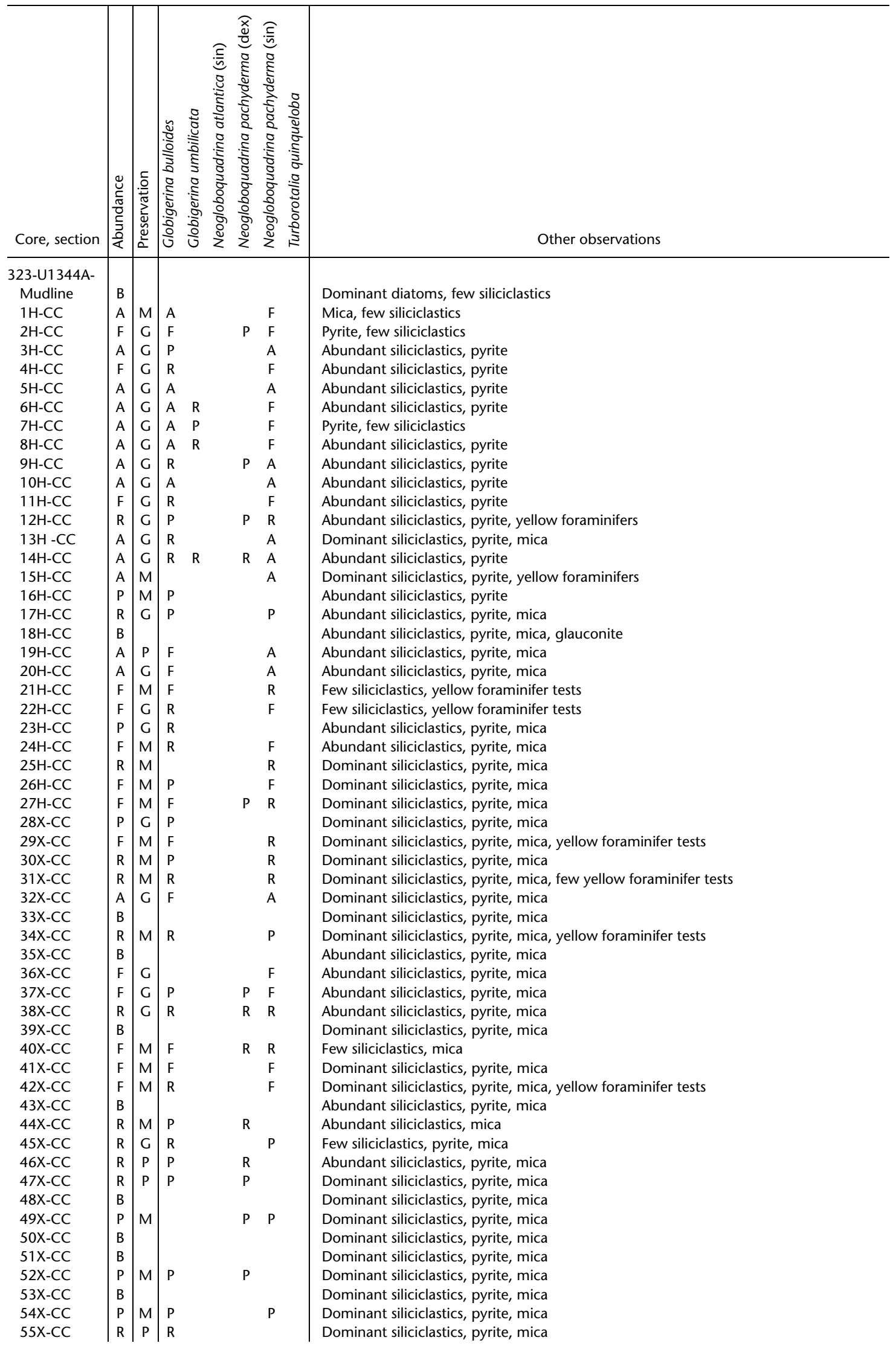


Table T4 (continued). (Continued on next page.)

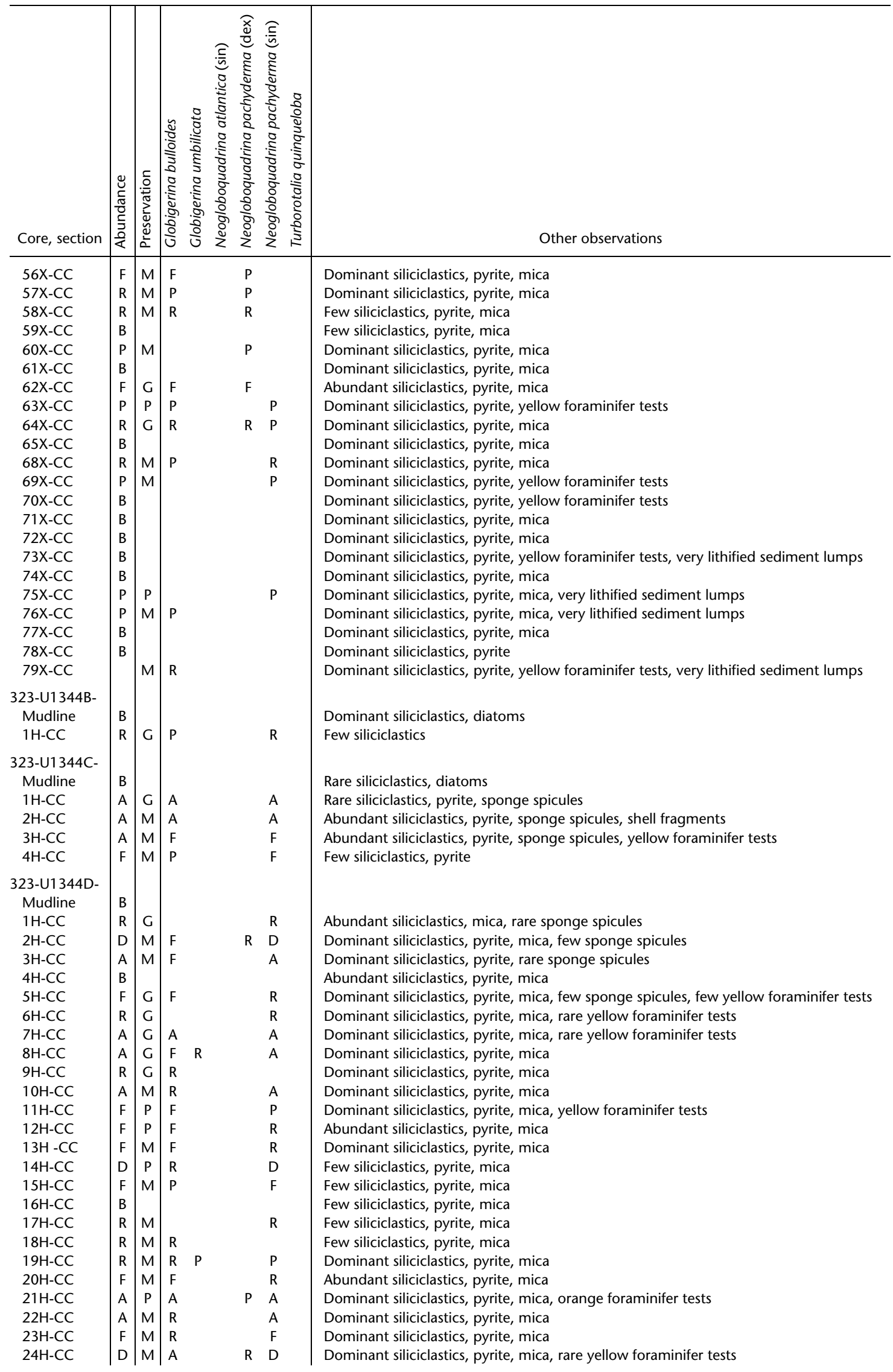


Table T4 (continued).

\begin{tabular}{|c|c|c|c|c|c|c|c|}
\hline Core, section & 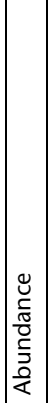 & 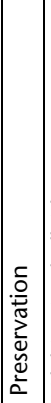 & 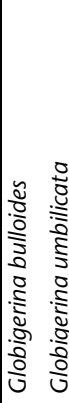 & 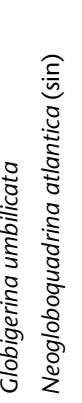 & 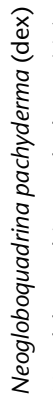 & 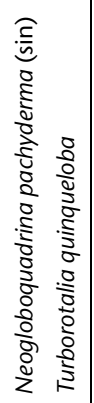 & Other observations \\
\hline $25 \mathrm{H}-\mathrm{CC}$ & $\mathrm{F}$ & $M$ & $\mathrm{R}$ & & & $\mathrm{F}$ & Dominant siliciclastics, pyrite, mica, yellow foraminifer tests \\
\hline $30 \mathrm{H}-\mathrm{CC}$ & $\mathrm{R}$ & G & $\mathrm{R}$ & & & & Dominant siliciclastics, pyrite, mica, yellow foraminifer tests \\
\hline $31 \mathrm{H}-\mathrm{CC}$ & B & & & & & & Dominant siliciclastics, pyrite, mica \\
\hline $32 \mathrm{H}-\mathrm{CC}$ & B & & & & & & Dominant siliciclastics, pyrite, mica \\
\hline 323-U1344E- & & & & & & & \\
\hline $1 \mathrm{H}-\mathrm{CC}$ & $\mathrm{F}$ & G & $\mathrm{F}$ & & & $\mathrm{F}$ & Abundant siliciclastics, pyrite, mica \\
\hline $2 \mathrm{H}-\mathrm{CC}$ & $\mathrm{D}$ & G & $\mathrm{F}$ & & & $\mathrm{D}$ & Few siliciclastics, pyrite, mica \\
\hline $3 \mathrm{H}-\mathrm{CC}$ & A & $M$ & $\mathrm{R}$ & & & $A$ & Few siliciclastics, pyrite, mica \\
\hline $4 \mathrm{H}-\mathrm{CC}$ & $\mathrm{R}$ & G & $P$ & & & $\mathrm{R}$ & Few siliciclastics, pyrite, mica \\
\hline $5 \mathrm{H}-\mathrm{CC}$ & $\mathrm{F}$ & G & $\mathrm{F}$ & & & & Abundant siliciclastics, pyrite, mica \\
\hline $6 \mathrm{H}-\mathrm{CC}$ & $\mathrm{D}$ & M & $A$ & & & $\mathrm{D}$ & Few siliciclastics, pyrite, mica \\
\hline $7 \mathrm{H}-\mathrm{CC}$ & $\mathrm{A}$ & $G$ & $\mathrm{P}$ & & & $A$ & Abundant siliciclastics, pyrite, mica \\
\hline $15 \mathrm{H}-\mathrm{CC}$ & $\mathrm{R}$ & $M$ & $P$ & & & $\mathrm{R}$ & Dominant siliciclastics, pyrite, mica, yellow foraminifer tests \\
\hline $16 \mathrm{H}-\mathrm{CC}$ & $\mathrm{R}$ & G & & & & $\mathrm{R}$ & Dominant siliciclastics, pyrite, mica, yellow foraminifer tests \\
\hline $17 \mathrm{H}-\mathrm{CC}$ & $\mathrm{R}$ & $M$ & & & & $\mathrm{R}$ & Dominant siliciclastics, pyrite, mica \\
\hline $18 \mathrm{H}-\mathrm{CC}$ & $\mathrm{F}$ & $\mathrm{M}$ & $\mathrm{R}$ & & & $\mathrm{F}$ & Dominant siliciclastics, pyrite, mica \\
\hline $19 \mathrm{H}-\mathrm{CC}$ & $\mathrm{P}$ & $M$ & & & & $P$ & Dominant siliciclastics, pyrite, mica \\
\hline $20 \mathrm{H}-\mathrm{CC}$ & $\mathrm{F}$ & $M$ & $\mathrm{R}$ & & & $\mathrm{F}$ & Dominant siliciclastics, pyrite, mica \\
\hline $21 \mathrm{H}-\mathrm{CC}$ & $\mathrm{F}$ & $M$ & $\mathrm{R}$ & & & $\mathrm{F}$ & Dominant siliciclastics, pyrite, mica, few yellow foraminifer tests \\
\hline $22 \mathrm{H}-\mathrm{CC}$ & $\mathrm{P}$ & $\mathrm{M}$ & & & $P$ & & Dominant siliciclastics, pyrite, mica \\
\hline $23 \mathrm{H}-\mathrm{CC}$ & $\mathrm{A}$ & $M$ & & & & A & Dominant siliciclastics, pyrite, mica \\
\hline
\end{tabular}

Notes: Abundance: $\mathrm{D}=$ dominant, $\mathrm{A}=$ abundant, $\mathrm{F}=$ few, $\mathrm{R}=$ rare, $\mathrm{P}=$ present, $\mathrm{B}=$ barren. Preservation: $\mathrm{G}=$ good, $\mathrm{M}=$ moderate, $\mathrm{P}=$ poor. $\mathrm{Dex}$ $=$ dextral, $\sin =$ sinistral. 


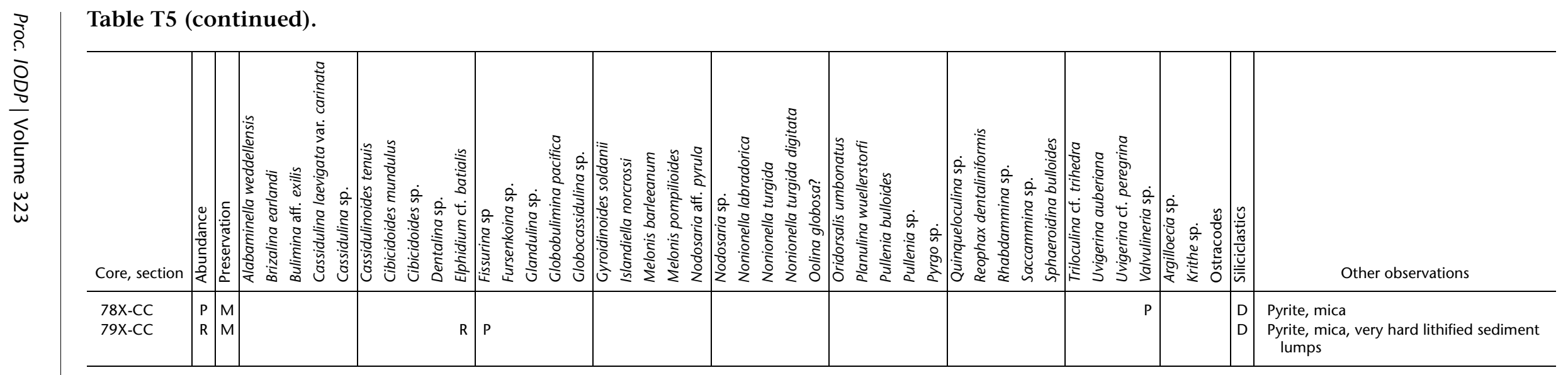

Notes: Abundance: $\mathrm{D}=$ dominant, $\mathrm{A}=$ abundant, $\mathrm{F}=$ few, $\mathrm{R}=$ rare, $\mathrm{P}=$ present, $\mathrm{B}=$ barren. Preservation: $\mathrm{G}=$ good, $\mathrm{M}=\mathrm{moderate}, \mathrm{P}=$ poor. 


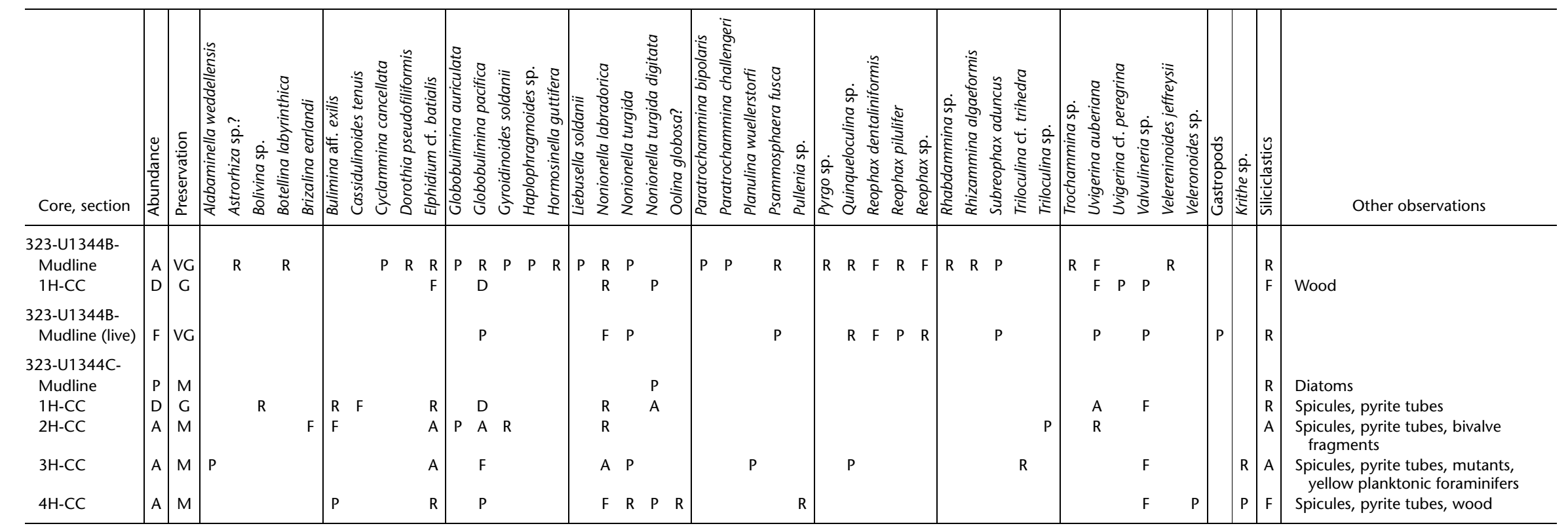

Notes: Abundance: $\mathrm{D}=$ dominant, $\mathrm{A}=$ abundant, $\mathrm{F}=$ few, $\mathrm{R}=$ rare, $\mathrm{P}=$ present. Preservation: $\mathrm{VG}=$ very good, $\mathrm{G}=$ good, $\mathrm{M}=$ moderate. Live $=$ Rose Bengal stained. 


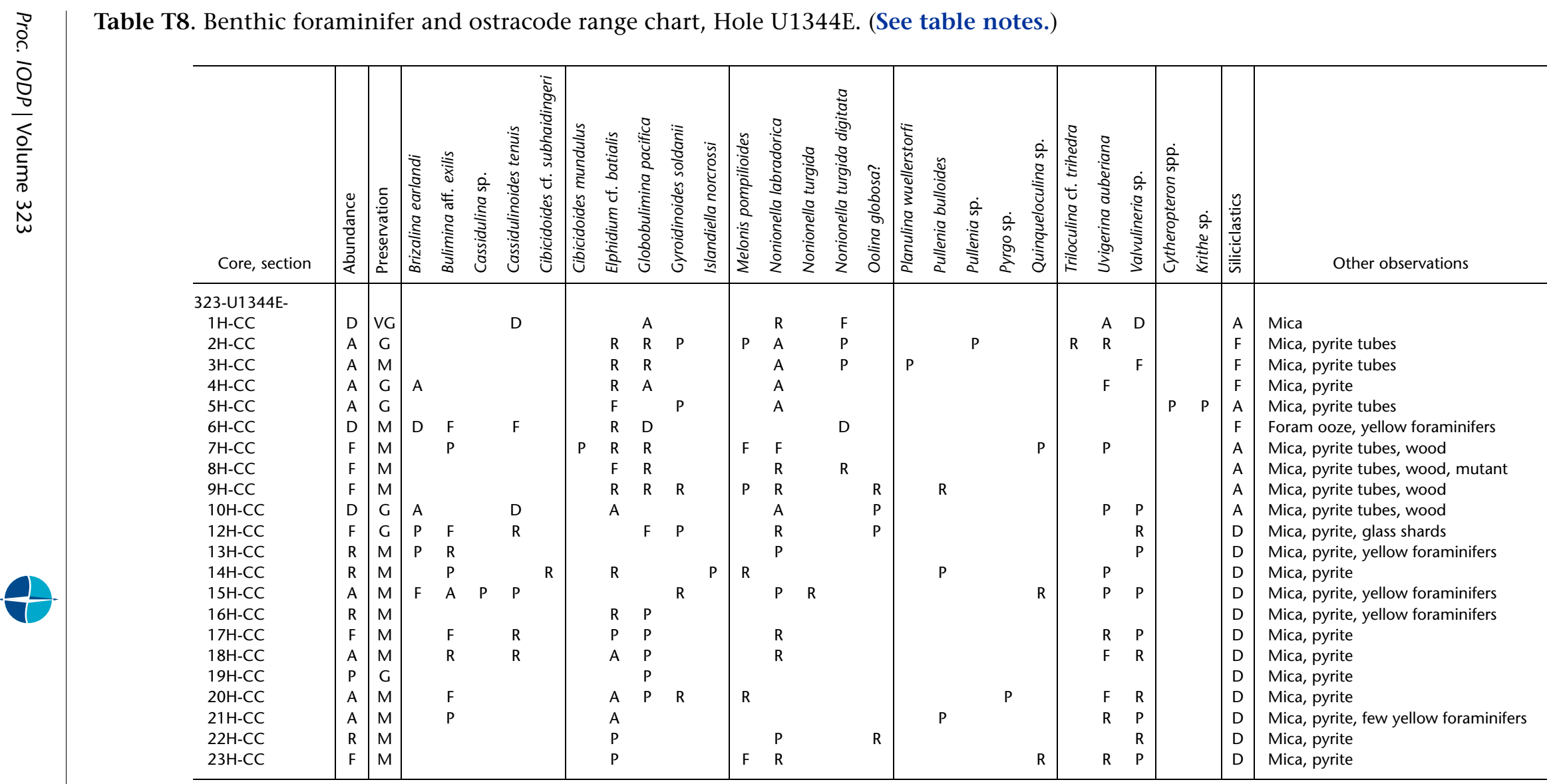

Notes: Abundance: $\mathrm{D}=$ dominant, $\mathrm{A}=$ abundant, $\mathrm{F}=$ few $\mathrm{R}=$ rare, $\mathrm{P}=$ present. Preservation: $\mathrm{VG}=$ very good, $\mathrm{G}=$ good, $\mathrm{M}=$ moderate.

Table T9. Diatom range chart, Hole U1344A. This table is available in an oversized format. 


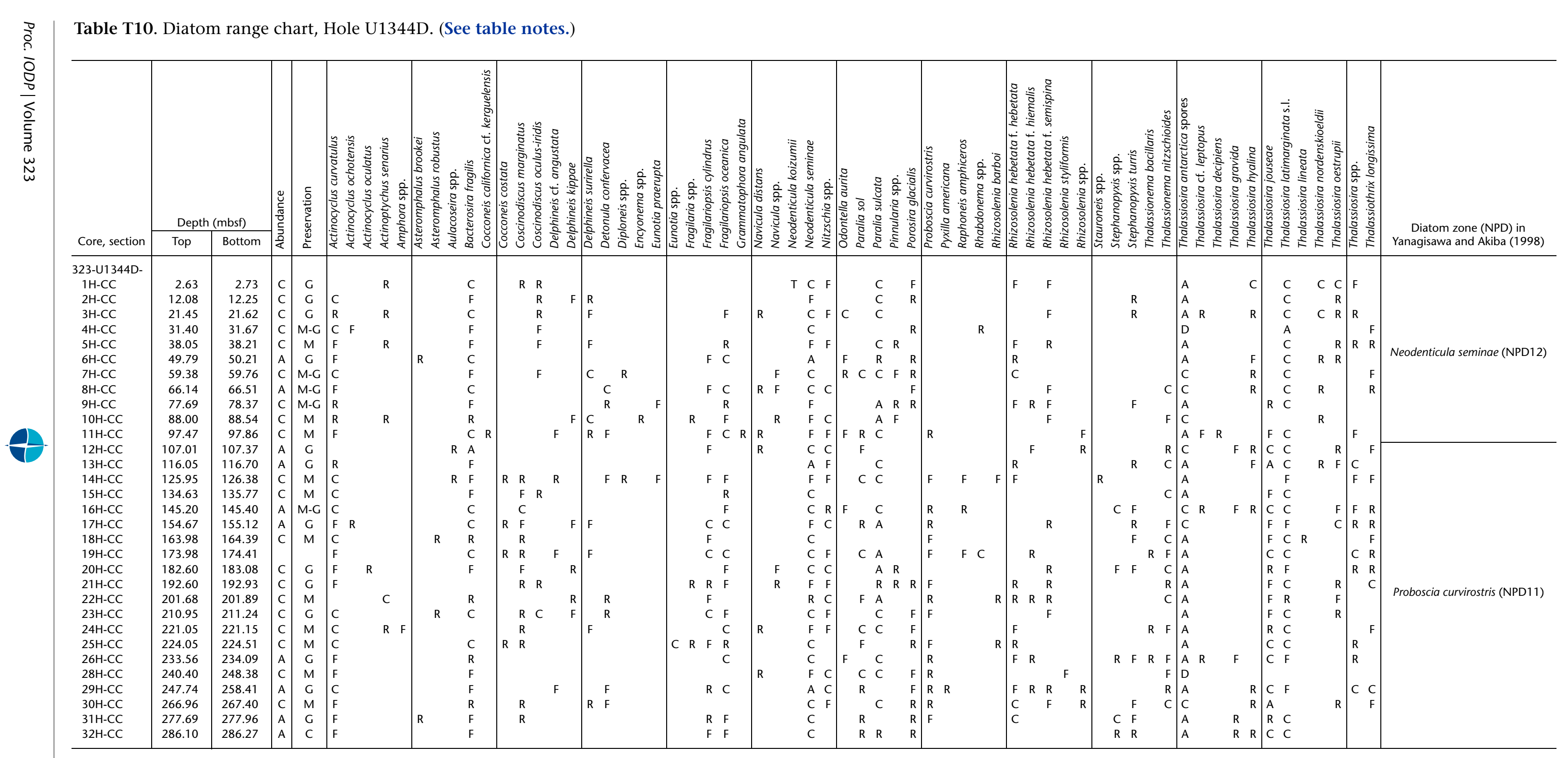

Notes: Abundance: $\mathrm{A}=$ abundant, $\mathrm{C}=$ common, $\mathrm{F}=$ few, $\mathrm{R}=$ rare. Preservation: $\mathrm{G}=$ good, $\mathrm{M}=$ moderate 


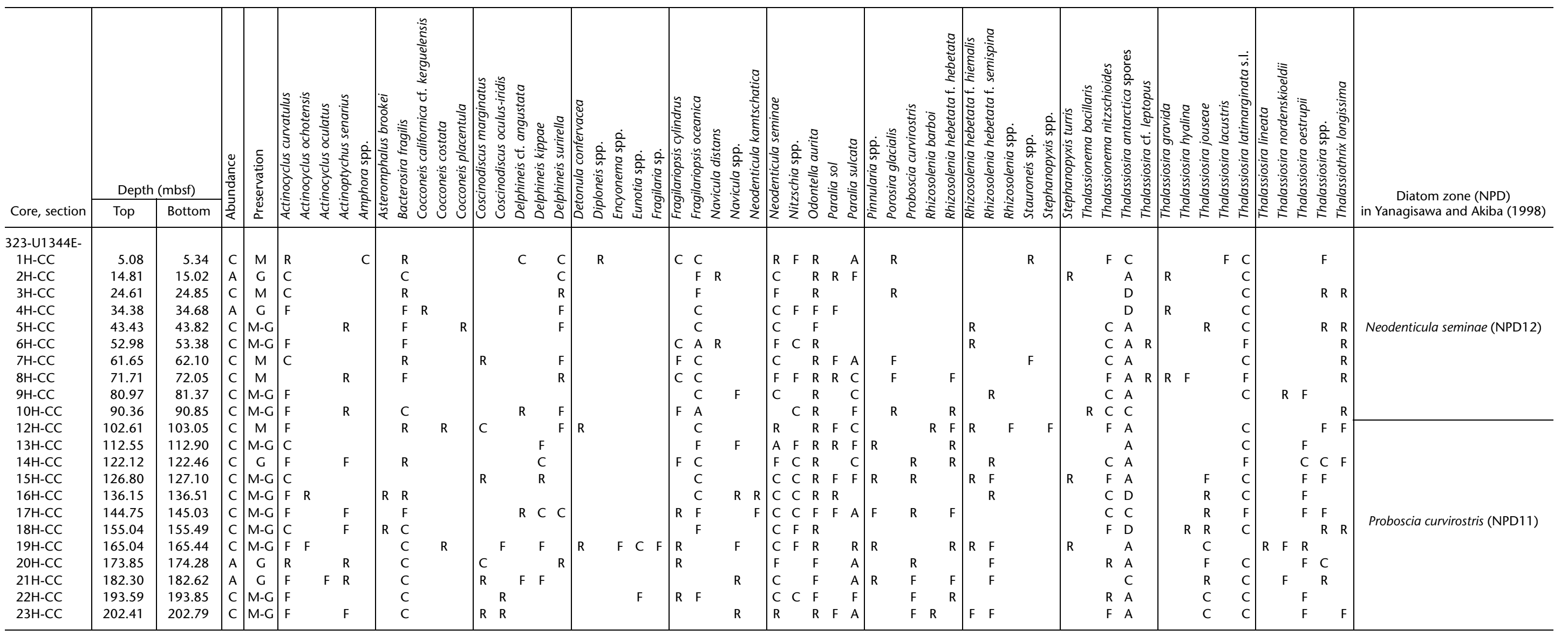

Notes: Abundance: $\mathrm{A}=$ abundant, $\mathrm{C}=$ common, $\mathrm{F}=$ few, $\mathrm{R}=$ rare. Preservation: $\mathrm{G}=$ good, $\mathrm{M}=$ moderate 
Table T12. First common occurrences of Proboscia curvirostris and Proboscia barboi, Hole U1344A. (See table note.)

\begin{tabular}{lcccc}
\hline \multirow{2}{*}{ Core, section } & \multicolumn{2}{c}{ Depth (mbsf) } & \multirow{2}{*}{$\begin{array}{c}\text { Proboscia } \\
\text { curvirostris }\end{array}$} & $\begin{array}{c}\text { Proboscia } \\
\text { barboi }\end{array}$ \\
\cline { 2 - 3 } 323-U1344A- & Bottom & & & \\
55X-CC & 521.34 & 521.80 & 9 & 1 \\
56X-CC & 529.96 & 530.31 & 15 & 5 \\
57X-CC & 539.93 & 540.28 & 0 & 2 \\
58X-CC & 549.10 & 549.57 & 1 & 16 \\
59X-CC & 558.38 & 558.79 & 1 & 13 \\
\hline
\end{tabular}

Note: The numbers represent counted diatom valve numbers in the coarse fraction $(>20 \mu \mathrm{m})$ slides produced for silicoflagellate counting.

Table T13. Last common occurrences of Proboscia curvirostris and Proboscia barboi, Hole U1344D. (See table note.)

\begin{tabular}{|c|c|c|c|c|}
\hline \multirow[b]{2}{*}{ Core, section } & \multicolumn{2}{|c|}{ Depth (mbsf) } & \multirow{2}{*}{$\begin{array}{l}\text { Proboscia } \\
\text { curvirostris }\end{array}$} & \multirow{2}{*}{$\begin{array}{c}\text { Proboscia } \\
\text { barboi }\end{array}$} \\
\hline & Top & Bottom & & \\
\hline \multicolumn{5}{|l|}{ 323-U1344D- } \\
\hline $10 \mathrm{H}-\mathrm{CC}$ & 88.00 & 88.54 & 0 & 0 \\
\hline $11 \mathrm{H}-\mathrm{CC}$ & 97.47 & 97.86 & 2 & 0 \\
\hline $12 \mathrm{H}-\mathrm{CC}$ & 107.01 & 107.37 & 9 & 0 \\
\hline $13 \mathrm{H}-\mathrm{CC}$ & 116.05 & 116.70 & 4 & 0 \\
\hline $14 \mathrm{H}-\mathrm{CC}$ & 125.95 & 126.38 & 1 & 0 \\
\hline
\end{tabular}

Note: The numbers represent counted diatom valve numbers in the coarse fraction $(>20 \mu \mathrm{m})$ slides produced for silicoflagellate counting. 
Table T14. Silicoflagellate and ebridian range chart, Holes U1344A and U1344D. (See table notes.)

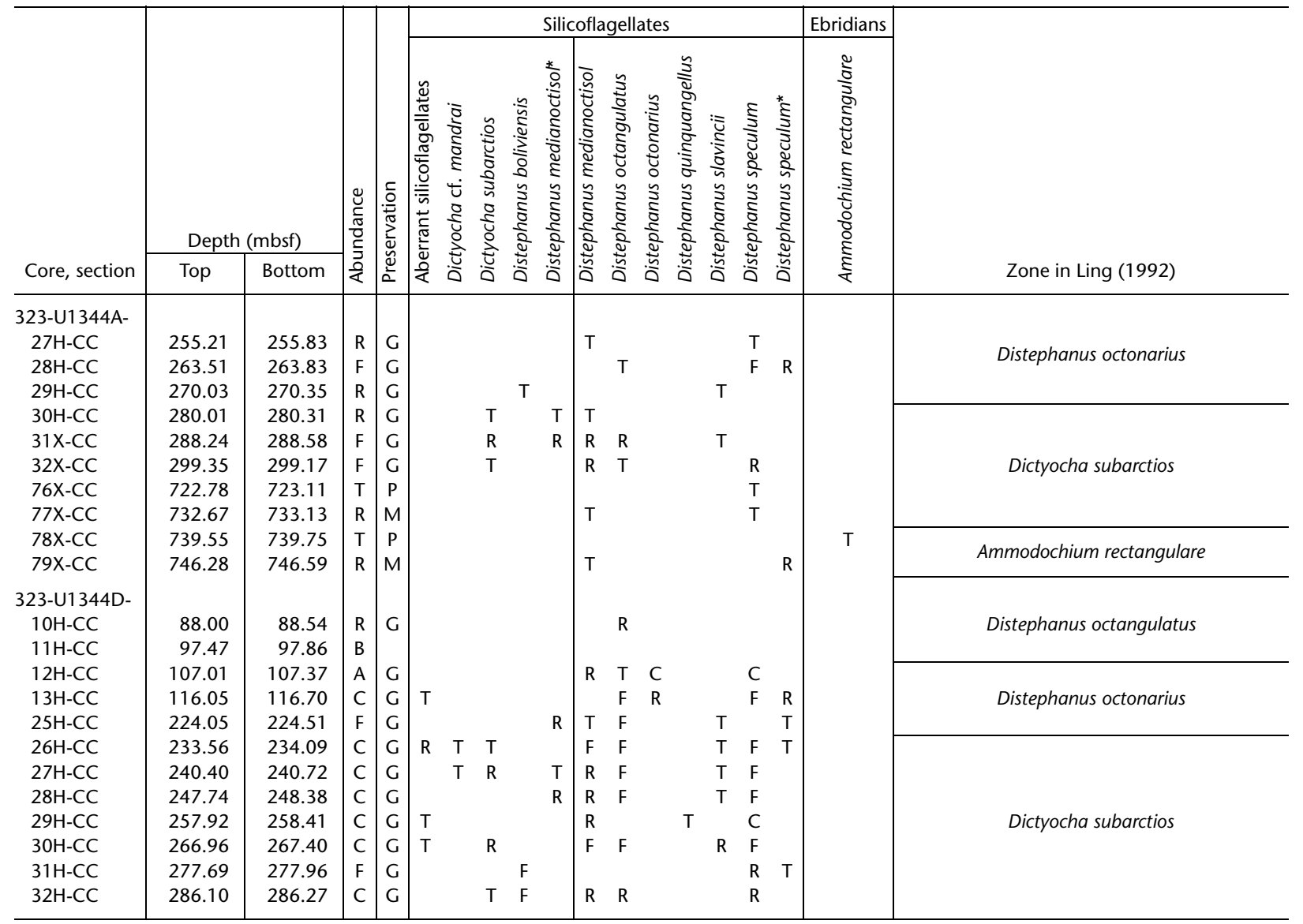

Notes: * $=$ with short radial spines. Abundance: $A=$ abundant, $C=$ common, $F=$ few, $R=$ rare, $T=$ trace, $B=$ barren. Preservation: $G=$ good, $M=$ moderate, $\mathrm{P}=$ poor. 
Table T15. Radiolarian datum events, Holes U1344A, U1344B, U1344C, U1344D, and U1344E. (See table note.)

\begin{tabular}{|c|c|c|c|c|c|c|c|c|c|c|c|c|c|c|}
\hline \multirow[b]{3}{*}{ Zone } & \multirow[b]{3}{*}{ Marker species } & \multirow[b]{3}{*}{ Age $(\mathrm{Ma})$} & \multicolumn{4}{|c|}{ Hole U1344A } & \multicolumn{4}{|c|}{ Hole U1344B } & \multicolumn{4}{|c|}{ Hole U1344C } \\
\hline & & & \multicolumn{2}{|c|}{ Core, section } & \multicolumn{2}{|c|}{ Depth (mbsf) } & \multicolumn{2}{|c|}{ Core, section } & \multicolumn{2}{|c|}{ Depth (mbsf) } & \multicolumn{2}{|c|}{ Core, section } & \multicolumn{2}{|c|}{ Depth (mbsf) } \\
\hline & & & Top & Bottom & Top & Bottom & Top & Bottom & Top & Bottom & Top & Bottom & Top & Bottom \\
\hline \multirow{3}{*}{ Botryostrobus aquilonaris } & T Lychnocanoma nipponica sakaii & 0.05 & $2 \mathrm{H}-\mathrm{CC}$ & $3 \mathrm{H}-\mathrm{CC}$ & 18.8 & 28.7 & & & & & $2 \mathrm{H}-\mathrm{CC}$ & $3 \mathrm{H}-\mathrm{CC}$ & 14.24 & 26.40 \\
\hline & T Spongodiscus sp. & $0.28-0.32$ & $11 \mathrm{H}-\mathrm{CC}$ & $12 \mathrm{H}-\mathrm{CC}$ & 104.5 & 114.0 & & & & & & & & \\
\hline & T Axoprunum acquilonium & $0.25-0.43$ & $12 \mathrm{H}-\mathrm{CC}$ & $13 \mathrm{H}-\mathrm{CC}$ & 114.0 & 123.5 & & & & & & & & \\
\hline Stylatractus universus & T Stylatractus universus & $0.41-0.51$ & \multicolumn{2}{|c|}{ Not found } & & & & & & & & & & \\
\hline Eucyrtidium matuyamai & T Eucyrtidium matuyamai & $0.9-1.5$ & $43 \mathrm{X}-\mathrm{CC}$ & $44 \mathrm{X}-\mathrm{CC}$ & 403.6 & 415.0 & & & & & & & & \\
\hline
\end{tabular}

Note: $\mathrm{T}=$ top, $\mathrm{B}=$ bottom .

\begin{tabular}{|c|c|c|c|c|c|c|c|c|c|c|}
\hline \multirow[b]{3}{*}{ Zone } & \multirow[b]{3}{*}{ Marker species } & \multirow[b]{3}{*}{ Age (Ma) } & \multicolumn{4}{|c|}{ Hole U1344D } & \multicolumn{4}{|c|}{ Hole U1344E } \\
\hline & & & \multicolumn{2}{|c|}{ Core, section } & \multicolumn{2}{|c|}{ Depth (mbsf) } & \multicolumn{2}{|c|}{ Core, section } & \multicolumn{2}{|c|}{ Depth (mbsf) } \\
\hline & & & Top & Bottom & Top & Bottom & Top & Bottom & Top & Bottom \\
\hline \multirow{3}{*}{ Botryostrobus aquilonaris } & T Lychnocanoma nipponica sakaii & 0.05 & $3 \mathrm{H}-\mathrm{CC}$ & $4 \mathrm{H}-\mathrm{CC}$ & 21.6 & 31.7 & $2 \mathrm{H}-\mathrm{CC}$ & $3 \mathrm{H}-\mathrm{CC}$ & 15.02 & 24.85 \\
\hline & T Spongodiscus sp. & $0.28-0.32$ & $11 \mathrm{H}-\mathrm{CC}$ & $12 \mathrm{H}-\mathrm{CC}$ & 97.9 & 107.4 & $10 \mathrm{H}-\mathrm{CC}$ & $12 \mathrm{H}-\mathrm{CC}$ & 90.85 & 103.05 \\
\hline & T Axoprunum acquilonium & $0.25-0.43$ & $17 \mathrm{H}-\mathrm{CC}$ & $18 \mathrm{H}-\mathrm{CC}$ & 155.1 & 164.4 & $12 \mathrm{H}-\mathrm{CC}$ & $13 \mathrm{H}-\mathrm{CC}$ & 103.05 & 112.90 \\
\hline Stylatractus universus & T Stylatractus universus & $0.41-0.51$ & $16 \mathrm{H}-\mathrm{CC}$ & $17 \mathrm{H}-\mathrm{CC}$ & 145.4 & 155.1 & $17 \mathrm{H}-\mathrm{CC}$ & $18 \mathrm{H}-\mathrm{CC}$ & 145.03 & 155.49 \\
\hline Eucyrtidium matuyamai & T Eucyrtidium matuyamai & $0.9-1.5$ & & & & & & & & \\
\hline
\end{tabular}




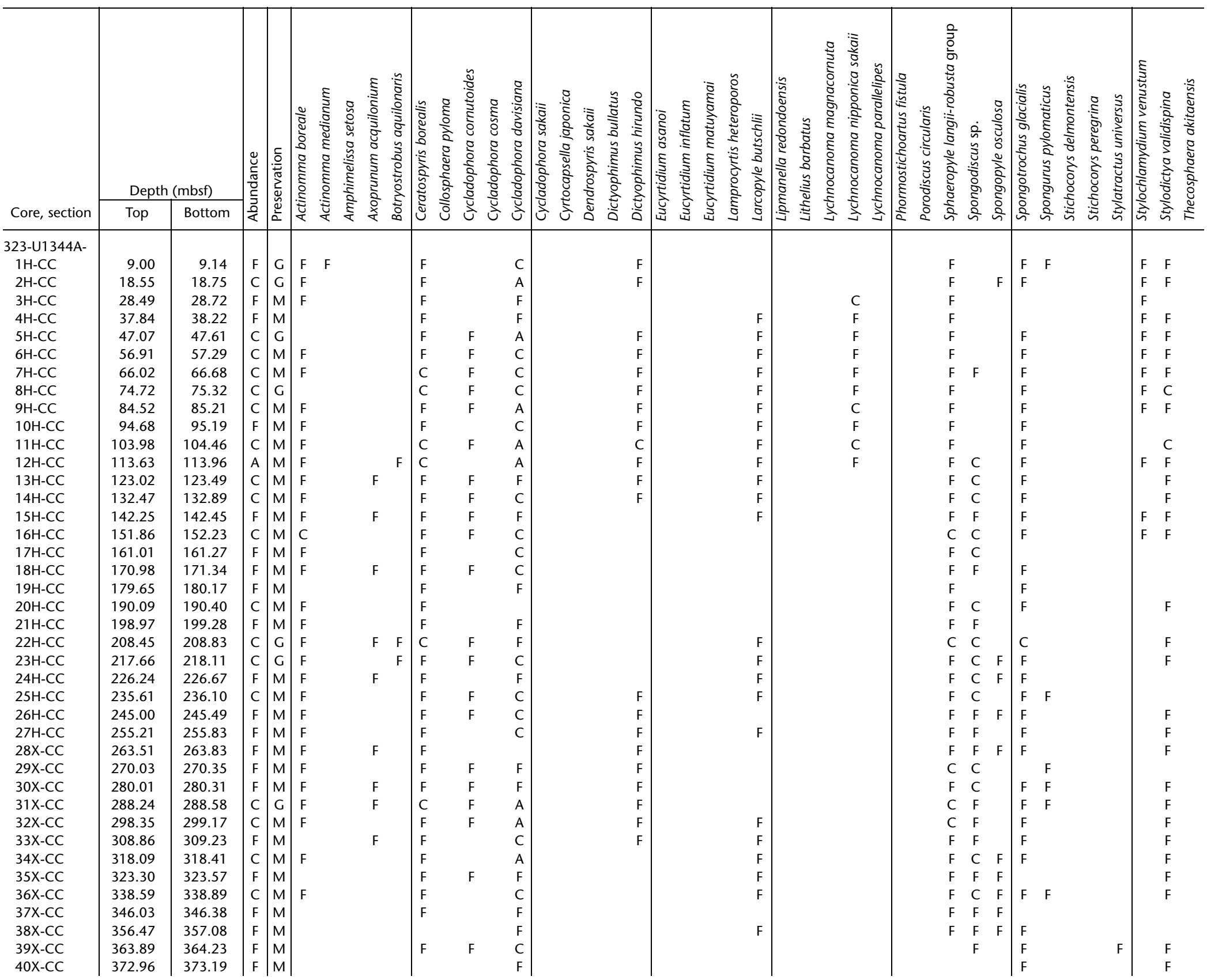

40X-CC

\begin{tabular}{l|l|l|l|l}
372.96 & 373.19 & $F$ & $M$ \\
\hline
\end{tabular} 


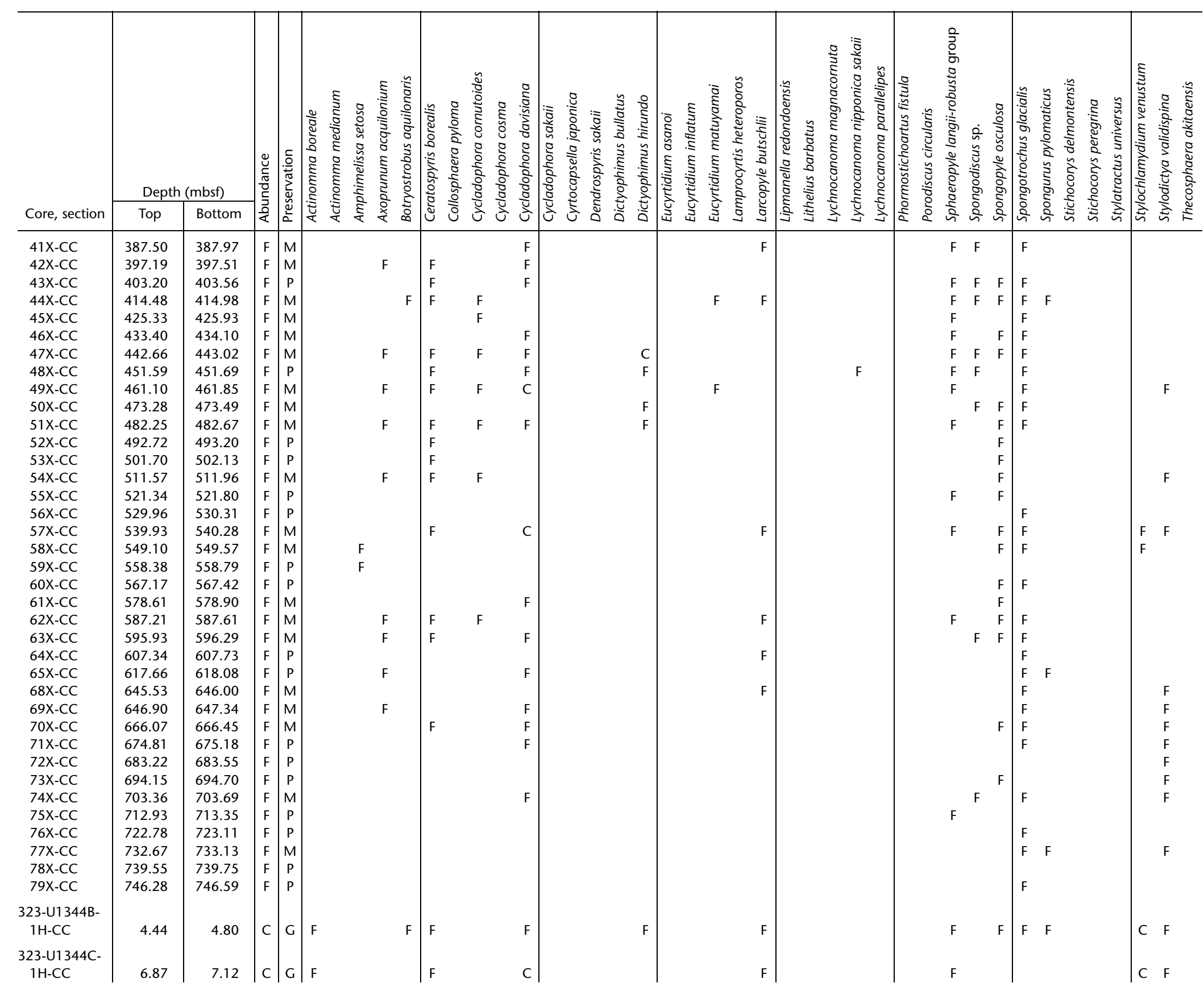



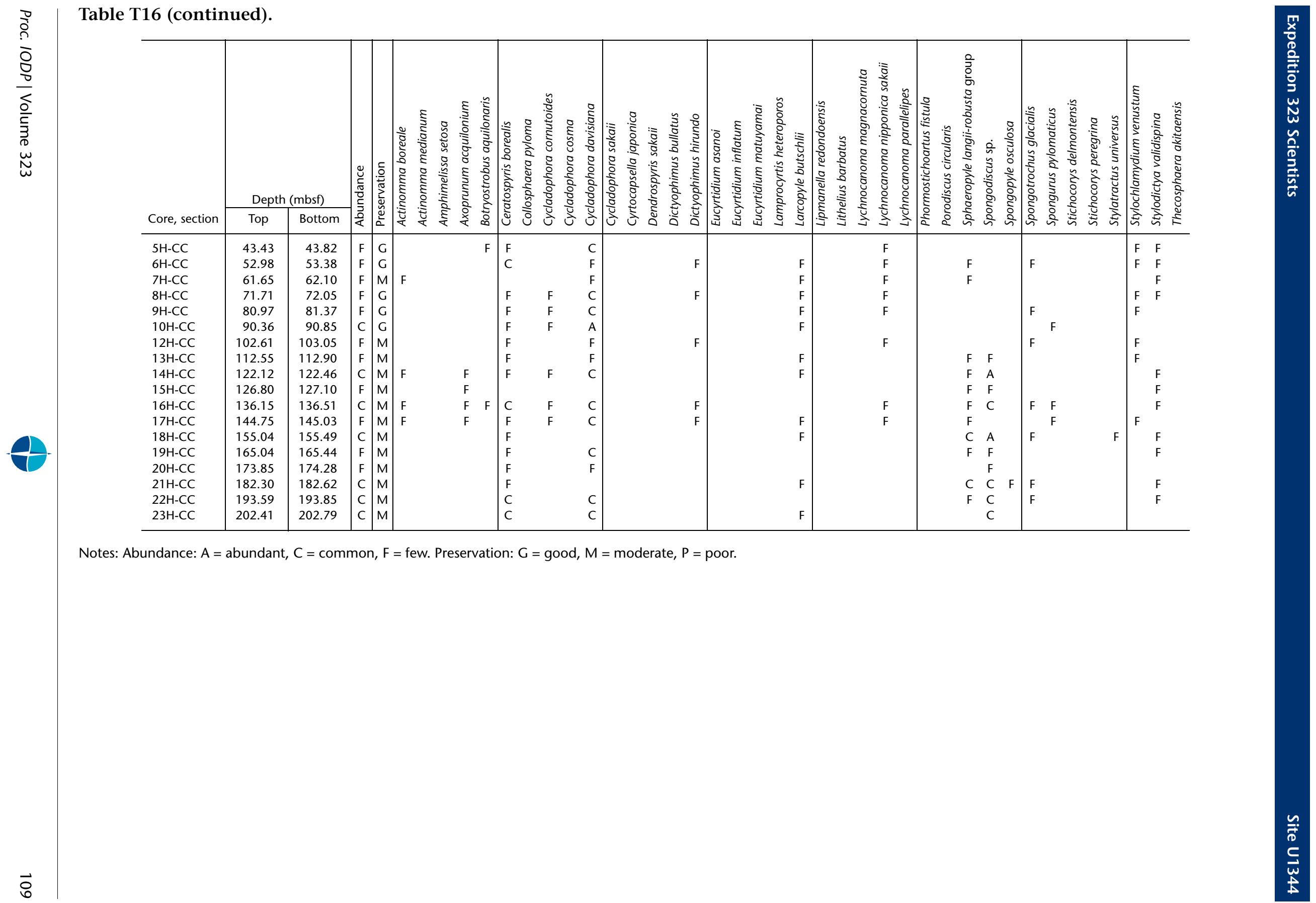

Notes: Abundance: $A=$ abundant, $C=$ common, $F=$ few. Preservation: $G=$ good, $M=$ moderate, $P=$ poor. 


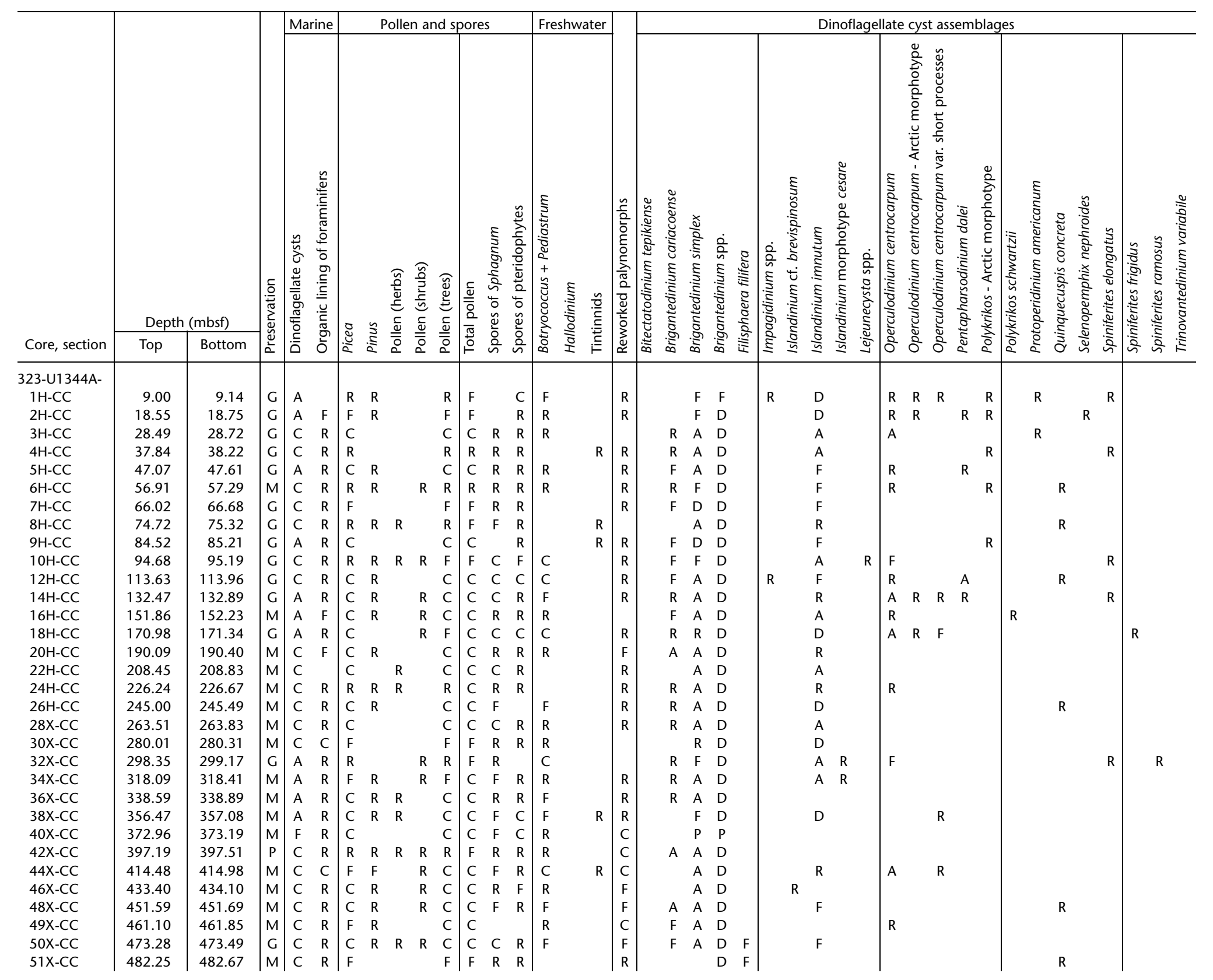




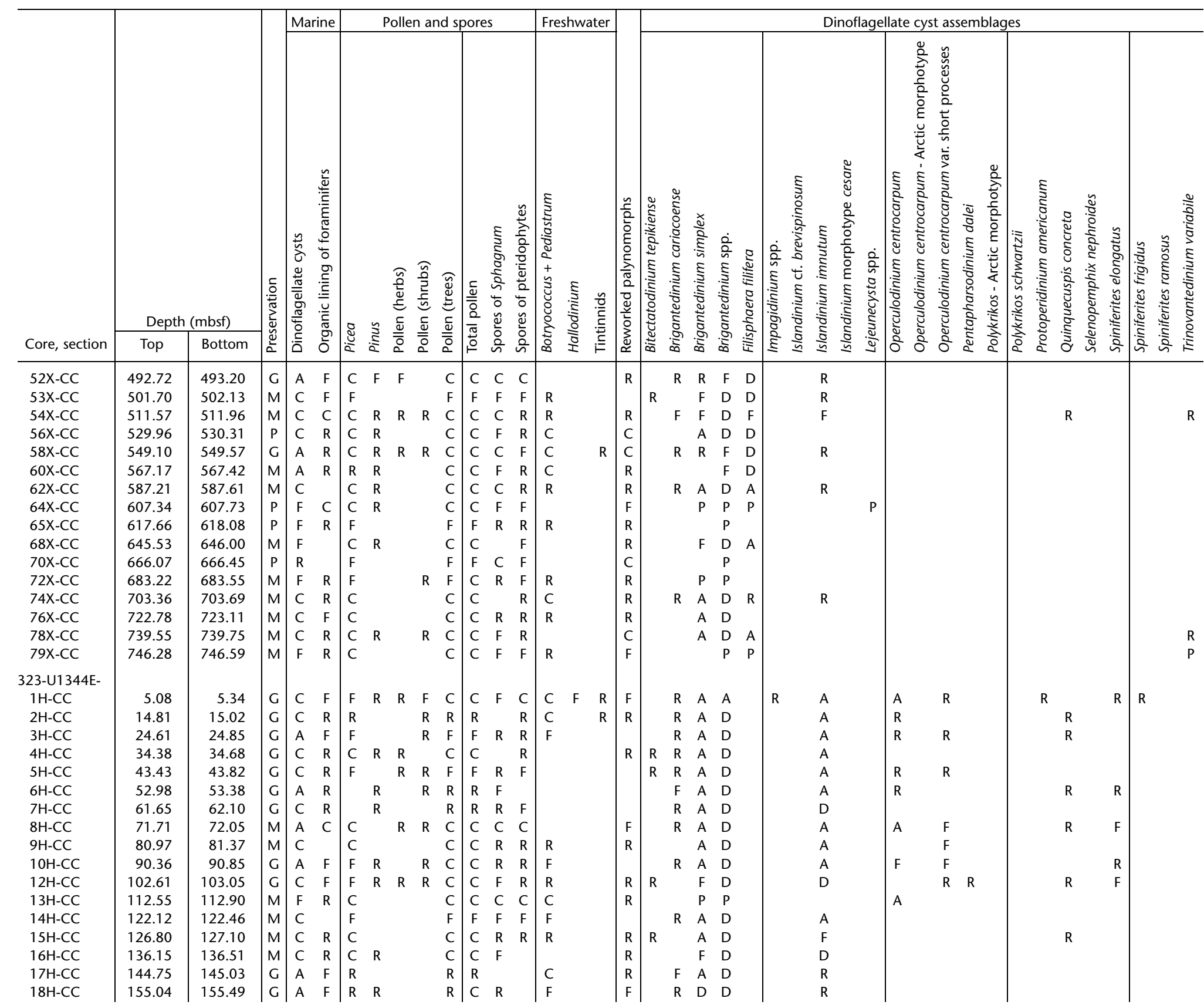

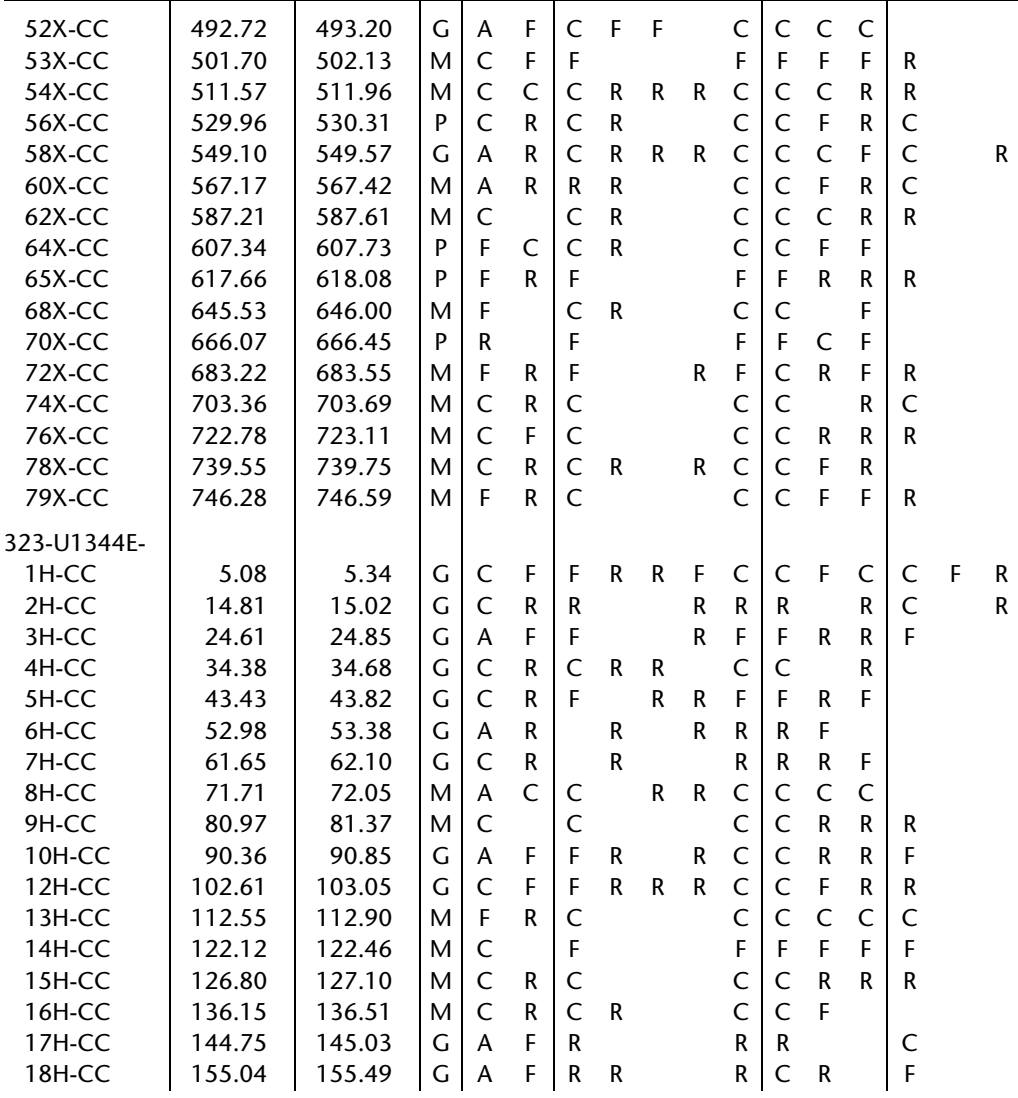




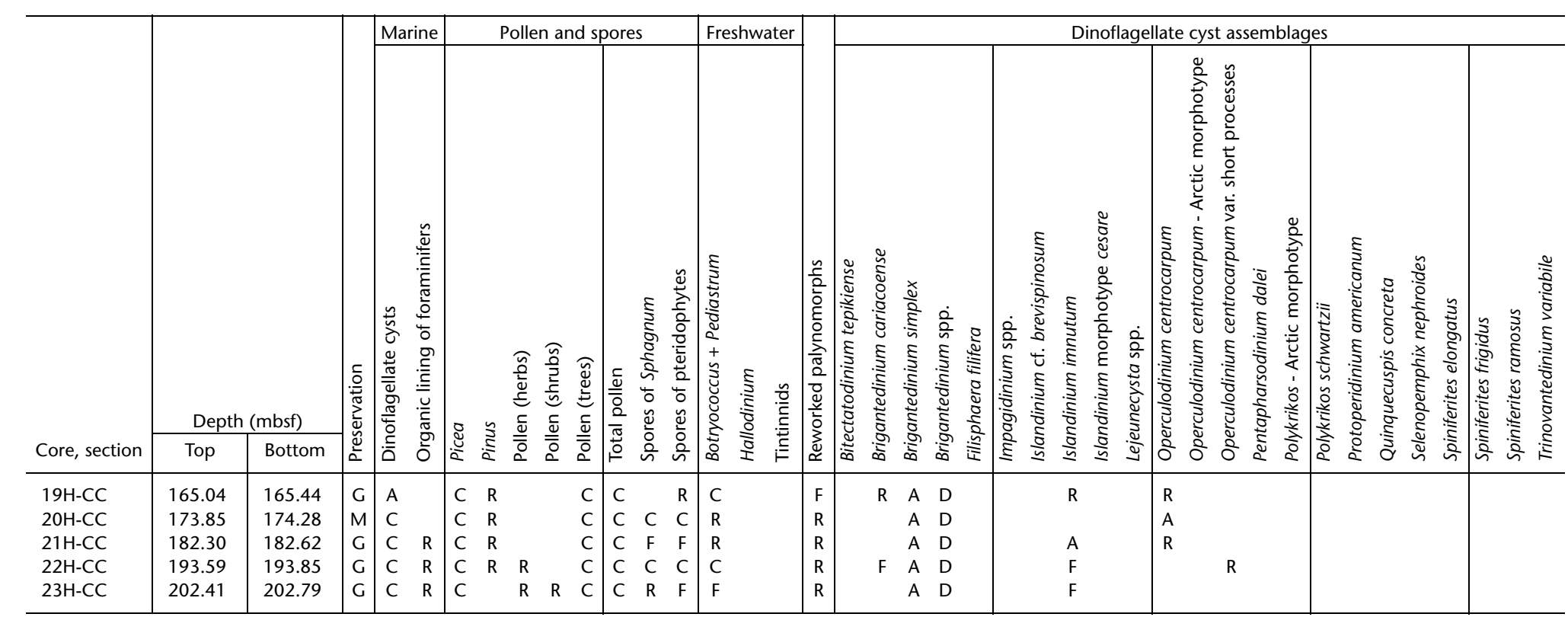


Table T18. Chron ages and preliminary depths, Holes U1344A and U1344D. (See table notes.)

\begin{tabular}{|c|c|c|c|c|c|c|c|c|c|}
\hline \multirow[b]{2}{*}{ Event } & \multirow[b]{2}{*}{$\begin{array}{l}\text { Age } \\
(\mathrm{ka})\end{array}$} & \multicolumn{5}{|c|}{ Hole U1344A } & \multicolumn{3}{|c|}{ Hole U1344D } \\
\hline & & $\begin{array}{l}\text { Core, section, } \\
\text { interval }(\mathrm{cm})\end{array}$ & $\begin{array}{l}\text { Depth } \\
\text { (mbsf) }\end{array}$ & $\begin{array}{c}\text { Average } \\
\text { depth } \\
\text { (mbsf) }\end{array}$ & $\begin{array}{l}\text { Error } \\
( \pm \mathrm{m})\end{array}$ & $\begin{array}{l}\text { Sed. rate } \\
(\mathrm{cm} / \mathrm{k} . \mathrm{y} .)\end{array}$ & $\begin{array}{l}\text { Core, section, } \\
\text { interval }(\mathrm{cm})\end{array}$ & $\begin{array}{l}\text { Depth } \\
\text { (mbsf) }\end{array}$ & $\begin{array}{l}\text { Sed. rate } \\
(\mathrm{cm} / \mathrm{k} . \mathrm{y} .)\end{array}$ \\
\hline & & 323-U1344A- & & & & & 323-U1344D- & & \\
\hline & 0 & & 0 & 0 & 0 & 35.4 & & 0 & 36.4 \\
\hline \multirow[t]{2}{*}{ B Brunhes } & 781 & $29 X-3,70$ & 267.3 & 276.495 & 9.195 & 33.1 & $32 \mathrm{H}-5,110$ & 284.07 & \\
\hline & & $31 X-3,75$ & 285.69 & & & & & & \\
\hline \multirow[t]{2}{*}{ T Jaramillo } & 998 & $37 X-6(T)$ & 346 & 348.35 & 2.35 & 33.2 & & & \\
\hline & & $38 X-1,105$ & 350.7 & & & & & & \\
\hline \multirow[t]{2}{*}{ B Jaramillo } & 1072 & $39 X-3,15$ & 362.4 & 372.95 & 10.55 & 39.2 & & & \\
\hline & & $41 X-4,45$ & 383.5 & & & & & & \\
\hline \multirow[t]{2}{*}{ T Cobb Mountain } & 1173 & $44 X-1,110$ & 408.3 & 412.55 & 4.25 & 88.7 & & & \\
\hline & & $45 \mathrm{X}-1(\mathrm{~T})$ & 416.8 & & & & & & \\
\hline B Cobb Mountain & 1185 & $45 X-5,45$ & 423.2 & & & 41.6 & & & \\
\hline T Olduvai & 1778 & $71 X-4,95$ & 669.9 & & & & & & \\
\hline
\end{tabular}

Notes: $\mathrm{T}=$ top, $\mathrm{B}=$ bottom. Sed. rate $=$ sedimentation rate. 
Table T19. Moisture and density, Hole U1344A. (Continued on next two pages.)

\begin{tabular}{|c|c|c|c|c|c|c|c|}
\hline \multirow{2}{*}{$\begin{array}{l}\text { Core, section, } \\
\text { interval }(\mathrm{cm})\end{array}$} & \multirow{2}{*}{$\begin{array}{l}\text { Depth } \\
\text { (mbsf) }\end{array}$} & \multicolumn{3}{|c|}{ Density $\left(\mathrm{g} / \mathrm{cm}^{3}\right)$} & \multirow{2}{*}{$\begin{array}{l}\text { Void } \\
\text { ratio }\end{array}$} & \multirow{2}{*}{$\begin{array}{l}\text { Water } \\
\text { content } \\
(\%)\end{array}$} & \multirow{2}{*}{$\begin{array}{l}\text { Porosity } \\
(\%)\end{array}$} \\
\hline & & Dry grain & Wet bulk & Dry bulk & & & \\
\hline \multicolumn{8}{|l|}{ 323-U1344A- } \\
\hline $1 \mathrm{H}-2,29-31$ & 1.8 & 2.66 & 1.45 & 0.71 & 2.92 & 50.91 & 74.52 \\
\hline $1 \mathrm{H}-4,29-31$ & 4.8 & 2.37 & 1.29 & 0.49 & 4.11 & 61.67 & 80.45 \\
\hline $1 \mathrm{H}-6,29-31$ & 7.8 & 2.68 & 1.45 & 0.71 & 2.93 & 50.77 & 74.58 \\
\hline $2 \mathrm{H}-2,29-31$ & 10.9 & 2.64 & 1.51 & 0.82 & 2.33 & 45.70 & 70.01 \\
\hline $2 \mathrm{H}-4,29-31$ & 13.9 & 2.77 & 1.50 & 0.78 & 2.71 & 48.05 & 73.03 \\
\hline $2 \mathrm{H}-6,29-31$ & 16.9 & 2.82 & 1.54 & 0.83 & 2.55 & 46.16 & 71.82 \\
\hline $3 \mathrm{H}-2,29-31$ & 20.4 & 2.67 & 1.50 & 0.80 & 2.49 & 46.91 & 71.33 \\
\hline $3 \mathrm{H}-4,29-31$ & 23.4 & 2.54 & 1.46 & 0.76 & 2.47 & 48.05 & 71.19 \\
\hline $3 \mathrm{H}-6,29-31$ & 26.4 & 2.68 & 1.54 & 0.86 & 2.24 & 44.37 & 69.17 \\
\hline $4 \mathrm{H}-2,29-31$ & 29.9 & 2.64 & 1.53 & 0.86 & 2.20 & 44.26 & 68.73 \\
\hline $4 \mathrm{H}-4,29-31$ & 33.0 & 2.86 & 1.59 & 0.90 & 2.28 & 43.23 & 69.54 \\
\hline $4 \mathrm{H}-6,29-31$ & 35.9 & 2.73 & 1.50 & 0.79 & 2.59 & 47.42 & 72.16 \\
\hline $5 \mathrm{H}-2,29-31$ & 38.4 & 2.71 & 1.56 & 0.88 & 2.19 & 43.58 & 68.69 \\
\hline $5 \mathrm{H}-4,29-31$ & 41.4 & 2.52 & 1.45 & 0.74 & 2.53 & 48.76 & 71.65 \\
\hline $5 \mathrm{H}-6,29-31$ & 44.4 & 2.70 & 1.61 & 0.97 & 1.86 & 39.79 & 64.99 \\
\hline $6 \mathrm{H}-2,29-31$ & 48.8 & 2.63 & 1.52 & 0.84 & 2.24 & 44.81 & 69.11 \\
\hline $6 \mathrm{H}-4,29-31$ & 51.8 & 2.69 & 1.39 & 0.62 & 3.58 & 55.45 & 78.18 \\
\hline $6 \mathrm{H}-6,29-31$ & 54.8 & 2.83 & 1.57 & 0.88 & 2.32 & 43.87 & 69.86 \\
\hline $7 \mathrm{H}-2,29-31$ & 58.0 & 2.70 & 1.60 & 0.95 & 1.92 & 40.52 & 65.74 \\
\hline 7H-4, 29-31 & 61.0 & 2.59 & 1.62 & 1.00 & 1.64 & 37.95 & 62.17 \\
\hline $7 \mathrm{H}-6,29-31$ & 64.0 & 2.72 & 1.64 & 1.01 & 1.78 & 38.57 & 64.00 \\
\hline $8 \mathrm{H}-2,29-31$ & 67.0 & 2.67 & 1.62 & 0.99 & 1.78 & 39.03 & 63.99 \\
\hline $8 \mathrm{H}-4,29-31$ & 69.9 & 2.80 & 1.63 & 0.97 & 1.97 & 40.22 & 66.29 \\
\hline $8 \mathrm{H}-6,29-31$ & 72.7 & 2.76 & 1.65 & 1.02 & 1.79 & 38.40 & 64.18 \\
\hline $9 \mathrm{H}-2,29-31$ & 76.7 & 2.67 & 1.53 & 0.85 & 2.25 & 44.57 & 69.24 \\
\hline $9 \mathrm{H}-4,29-31$ & 79.5 & 2.65 & 1.67 & 1.07 & 1.55 & 36.06 & 60.81 \\
\hline $9 \mathrm{H}-6,29-31$ & 82.5 & 2.72 & 1.72 & 1.13 & 1.46 & 34.11 & 59.32 \\
\hline $10 \mathrm{H}-2,29-31$ & 86.7 & 2.58 & 1.49 & 0.79 & 2.37 & 46.64 & 70.30 \\
\hline $10 \mathrm{H}-4,29-31$ & 89.7 & 2.77 & 1.72 & 1.13 & 1.52 & 34.59 & 60.26 \\
\hline $10 \mathrm{H}-6,29-31$ & 92.7 & 2.81 & 1.63 & 0.97 & 2.00 & 40.53 & 66.69 \\
\hline $11 \mathrm{H}-4,29-31$ & 98.5 & 2.63 & 1.70 & 1.13 & 1.39 & 33.75 & 58.10 \\
\hline $11 \mathrm{H}-6,29-31$ & 101.4 & 3.30 & 2.08 & 1.55 & 1.16 & 25.48 & 53.74 \\
\hline $12 \mathrm{H}-2,29-31$ & 105.4 & 2.69 & 1.71 & 1.13 & 1.44 & 34.13 & 59.07 \\
\hline $12 \mathrm{H}-6,29-31$ & 111.2 & 2.80 & 1.67 & 1.04 & 1.76 & 37.63 & 63.74 \\
\hline $13 \mathrm{H}-2,29-31$ & 114.9 & 2.64 & 1.53 & 0.85 & 2.23 & 44.61 & 69.03 \\
\hline $13 \mathrm{H}-4,29-31$ & 117.9 & 2.62 & 1.79 & 1.28 & 1.08 & 28.66 & 52.00 \\
\hline $13 \mathrm{H}-6,29-31$ & 120.8 & 2.69 & 1.74 & 1.17 & 1.34 & 32.58 & 57.33 \\
\hline $14 \mathrm{H}-2,29-31$ & 124.1 & 2.71 & 1.72 & 1.13 & 1.45 & 34.00 & 59.16 \\
\hline $14 \mathrm{H}-4,29-31$ & 127.1 & 2.78 & 1.75 & 1.17 & 1.44 & 33.38 & 59.08 \\
\hline $14 \mathrm{H}-6,29-31$ & 130.1 & 2.68 & 1.67 & 1.06 & 1.59 & 36.36 & 61.40 \\
\hline $15 \mathrm{H}-2,29-31$ & 133.9 & 2.71 & 1.64 & 1.00 & 1.77 & 38.61 & 63.92 \\
\hline $15 \mathrm{H}-4,29-31$ & 136.7 & 2.58 & 1.58 & 0.95 & 1.81 & 40.20 & 64.39 \\
\hline $15 \mathrm{H}-6,29-31$ & 139.7 & 2.68 & 1.65 & 1.03 & 1.67 & 37.53 & 62.58 \\
\hline $16 \mathrm{H}-2,29-31$ & 143.0 & 2.53 & 1.51 & 0.83 & 2.14 & 44.68 & 68.13 \\
\hline $16 \mathrm{H}-4,29-31$ & 146.0 & 2.73 & 1.60 & 0.94 & 2.00 & 41.19 & 66.62 \\
\hline $16 \mathrm{H}-6,29-31$ & 148.8 & 2.75 & 1.71 & 1.11 & 1.54 & 35.09 & 60.68 \\
\hline $17 \mathrm{H}-2,27-29$ & 152.4 & 2.72 & 1.69 & 1.08 & 1.57 & 35.75 & 61.06 \\
\hline $17 \mathrm{H}-4,28-30$ & 155.1 & 2.64 & 1.72 & 1.15 & 1.34 & 33.01 & 57.35 \\
\hline $17 \mathrm{H}-6,28-30$ & 158.1 & 2.69 & 1.72 & 1.14 & 1.41 & 33.67 & 58.58 \\
\hline $18 \mathrm{H}-2,28-30$ & 161.9 & 2.69 & 1.74 & 1.17 & 1.35 & 32.75 & 57.50 \\
\hline $18 \mathrm{H}-4,28-30$ & 164.8 & 2.83 & 1.69 & 1.06 & 1.74 & 37.19 & 63.52 \\
\hline $18 \mathrm{H}-6,28-30$ & 167.8 & 2.42 & 1.60 & 1.01 & 1.45 & 36.62 & 59.15 \\
\hline $19 \mathrm{H}-2,29-31$ & 171.6 & 2.69 & 1.62 & 0.98 & 1.81 & 39.30 & 64.44 \\
\hline $19 \mathrm{H}-4,29-31$ & 174.4 & 2.62 & 1.61 & 0.99 & 1.72 & 38.75 & 63.25 \\
\hline $19 \mathrm{H}-6,29-31$ & 177.4 & 2.66 & 1.70 & 1.12 & 1.43 & 34.17 & 58.80 \\
\hline $20 \mathrm{H}-2,29-31$ & 181.7 & 2.66 & 1.67 & 1.07 & 1.56 & 36.05 & 60.90 \\
\hline $20 \mathrm{H}-4,29-31$ & 184.7 & 2.66 & 1.63 & 1.00 & 1.73 & 38.48 & 63.41 \\
\hline $20 \mathrm{H}-6,29-31$ & 187.6 & 2.64 & 1.71 & 1.14 & 1.36 & 33.29 & 57.72 \\
\hline $21 \mathrm{H}-2,29-31$ & 190.7 & 2.75 & 1.77 & 1.21 & 1.32 & 31.79 & 56.97 \\
\hline $21 \mathrm{H}-4,29-31$ & 193.6 & 2.62 & 1.71 & 1.15 & 1.33 & 32.89 & 57.01 \\
\hline $21 \mathrm{H}-6,29-31$ & 196.3 & 2.65 & 1.68 & 1.10 & 1.48 & 34.96 & 59.61 \\
\hline $22 \mathrm{H}-2,39-41$ & 200.4 & 2.56 & 1.57 & 0.93 & 1.85 & 40.90 & 64.86 \\
\hline $22 \mathrm{H}-4,29-31$ & 203.2 & 2.67 & 1.72 & 1.15 & 1.37 & 33.18 & 57.87 \\
\hline $22 \mathrm{H}-6,29-31$ & 205.7 & 2.69 & 1.70 & 1.11 & 1.48 & 34.65 & 59.67 \\
\hline $23 \mathrm{H}-2,29-31$ & 210.4 & 2.71 & 1.67 & 1.06 & 1.62 & 36.55 & 61.80 \\
\hline $23 \mathrm{H}-4,29-31$ & 213.3 & 2.53 & 1.61 & 1.01 & 1.58 & 37.47 & 61.18 \\
\hline $23 \mathrm{H}-6,29-31$ & 216.2 & 2.66 & 1.73 & 1.16 & 1.34 & 32.82 & 57.35 \\
\hline
\end{tabular}


Table T19 (continued). (Continued on next page.)

\begin{tabular}{|c|c|c|c|c|c|c|c|}
\hline \multirow{2}{*}{$\begin{array}{l}\text { Core, section, } \\
\text { interval }(\mathrm{cm})\end{array}$} & \multirow{2}{*}{$\begin{array}{l}\text { Depth } \\
\text { (mbsf) }\end{array}$} & \multicolumn{3}{|c|}{ Density $\left(\mathrm{g} / \mathrm{cm}^{3}\right)$} & \multirow{2}{*}{$\begin{array}{l}\text { Void } \\
\text { ratio }\end{array}$} & \multirow{2}{*}{$\begin{array}{l}\text { Water } \\
\text { content } \\
(\%)\end{array}$} & \multirow{2}{*}{$\begin{array}{c}\text { Porosity } \\
\text { (\%) }\end{array}$} \\
\hline & & Dry grain & Wet bulk & Dry bulk & & & \\
\hline $24 \mathrm{H}-2,29-31$ & 219.9 & 2.63 & 1.69 & 1.11 & 1.41 & 34.20 & 58.58 \\
\hline $24 \mathrm{H}-4,29-31$ & 222.7 & 2.65 & 1.70 & 1.12 & 1.43 & 34.28 & 58.89 \\
\hline $24 \mathrm{H}-6,29-31$ & 225.7 & 2.30 & 1.62 & 1.10 & 1.13 & 32.37 & 53.14 \\
\hline $25 \mathrm{H}-2,29-31$ & 228.5 & 2.75 & 1.71 & 1.11 & 1.54 & 34.99 & 60.55 \\
\hline $25 \mathrm{H}-4,29-31$ & 231.5 & 2.60 & 1.73 & 1.18 & 1.24 & 31.63 & 55.35 \\
\hline $25 \mathrm{H}-6,29-31$ & 234.3 & 2.65 & 1.65 & 1.04 & 1.61 & 36.96 & 61.71 \\
\hline $26 \mathrm{H}-2,29-31$ & 236.7 & 2.58 & 1.61 & 0.99 & 1.68 & 38.48 & 62.62 \\
\hline $26 \mathrm{H}-4,29-31$ & 239.3 & 2.63 & 1.62 & 0.99 & 1.73 & 38.68 & 63.31 \\
\hline $26 \mathrm{H}-6,29-31$ & 242.3 & 2.69 & 1.73 & 1.16 & 1.38 & 33.12 & 57.95 \\
\hline $27 \mathrm{H}-2,29-31$ & 246.8 & 1.93 & 1.44 & 0.90 & 1.18 & 37.31 & 54.18 \\
\hline $27 \mathrm{H}-4,29-31$ & 249.3 & 2.63 & 1.65 & 1.04 & 1.60 & 36.85 & 61.47 \\
\hline $27 \mathrm{H}-6,29-31$ & 252.1 & 2.66 & 1.71 & 1.14 & 1.39 & 33.57 & 58.17 \\
\hline $28 \mathrm{X}-2,29-31$ & 256.9 & 2.68 & 1.72 & 1.14 & 1.41 & 33.70 & 58.52 \\
\hline $28 X-4,29-31$ & 259.9 & 2.69 & 1.62 & 0.98 & 1.82 & 39.28 & 64.48 \\
\hline $28 X-6,29-31$ & 262.9 & 2.54 & 1.58 & 0.95 & 1.75 & 39.74 & 63.58 \\
\hline $29 X-2,29-31$ & 265.4 & 2.59 & 1.59 & 0.96 & 1.77 & 39.62 & 63.92 \\
\hline $29 X-4,29-31$ & 268.4 & 2.57 & 1.59 & 0.97 & 1.73 & 39.29 & 63.37 \\
\hline $30 X-2,29-31$ & 274.0 & 2.73 & 1.70 & 1.10 & 1.55 & 35.32 & 60.74 \\
\hline $30 X-4,29-31$ & 277.0 & 2.72 & 1.70 & 1.10 & 1.54 & 35.30 & 60.60 \\
\hline $30 X-6,29-31$ & 279.8 & 2.56 & 1.68 & 1.10 & 1.37 & 34.06 & 57.76 \\
\hline $31 X-2,29-31$ & 283.7 & 2.62 & 1.62 & 1.01 & 1.67 & 38.05 & 62.56 \\
\hline $31 \mathrm{X}-4,29-31$ & 286.7 & 3.12 & 2.16 & 1.70 & 0.86 & 21.13 & 46.17 \\
\hline $32 X-2,29-31$ & 294.2 & 2.67 & 1.58 & 0.93 & 1.97 & 41.37 & 66.32 \\
\hline $32 X-4,29-31$ & 297.0 & 2.66 & 1.61 & 0.98 & 1.80 & 39.43 & 64.34 \\
\hline $33 X-2,29-31$ & 303.8 & 2.57 & 1.63 & 1.03 & 1.55 & 36.80 & 60.83 \\
\hline $33 X-4,29-31$ & 306.8 & 2.63 & 1.66 & 1.06 & 1.54 & 36.14 & 60.70 \\
\hline $34 \mathrm{X}-2,29-31$ & 313.4 & 2.66 & 1.73 & 1.16 & 1.33 & 32.66 & 57.13 \\
\hline $34 X-4,29-31$ & 316.4 & 2.73 & 1.75 & 1.18 & 1.35 & 32.42 & 57.51 \\
\hline $35 X-1,29-31$ & 321.2 & 2.71 & 1.69 & 1.08 & 1.57 & 35.77 & 61.02 \\
\hline $36 \mathrm{X}-2,29-31$ & 332.2 & 2.65 & 1.77 & 1.23 & 1.20 & 30.47 & 54.48 \\
\hline $36 X-4,29-31$ & 335.2 & 2.68 & 1.75 & 1.20 & 1.28 & 31.69 & 56.23 \\
\hline $36 X-6,29-31$ & 338.2 & 2.66 & 1.69 & 1.11 & 1.46 & 34.65 & 59.36 \\
\hline $37 X-4,29-31$ & 341.7 & 2.73 & 1.73 & 1.14 & 1.45 & 33.83 & 59.12 \\
\hline $37 X-6,29-31$ & 344.7 & 2.74 & 1.79 & 1.24 & 1.27 & 30.87 & 55.86 \\
\hline $38 X-2,29-31$ & 350.7 & 2.60 & 1.71 & 1.14 & 1.33 & 33.04 & 57.01 \\
\hline $38 X-4,29-31$ & 354.4 & 2.68 & 1.69 & 1.10 & 1.48 & 34.87 & 59.76 \\
\hline $39 X-2,29-31$ & 361.0 & 2.65 & 1.70 & 1.11 & 1.43 & 34.27 & 58.82 \\
\hline $39 X-4,29-31$ & 363.4 & 2.75 & 1.75 & 1.18 & 1.38 & 32.70 & 58.06 \\
\hline $40 X-2,29-31$ & 370.6 & 2.76 & 1.53 & 0.82 & 2.50 & 46.29 & 71.46 \\
\hline $40 X-4,29-31$ & 372.5 & 2.52 & 1.61 & 1.01 & 1.55 & 37.26 & 60.85 \\
\hline $41 X-2,29-31$ & 380.3 & 2.62 & 1.67 & 1.08 & 1.48 & 35.29 & 59.71 \\
\hline $41 X-4,29-31$ & 383.3 & 2.62 & 1.68 & 1.09 & 1.46 & 34.92 & 59.27 \\
\hline $41 X-6,29-31$ & 386.3 & 2.78 & 1.84 & 1.31 & 1.16 & 28.77 & 53.63 \\
\hline $42 X-2,29-31$ & 389.9 & 2.65 & 1.63 & 1.01 & 1.70 & 38.12 & 62.90 \\
\hline $42 X-4,29-31$ & 389.8 & 2.59 & 1.71 & 1.15 & 1.31 & 32.82 & 56.65 \\
\hline $42 X-6,29-31$ & 395.8 & 3.00 & 1.87 & 1.30 & 1.36 & 30.55 & 57.70 \\
\hline $43 X-2,29-31$ & 399.4 & 2.70 & 1.73 & 1.15 & 1.39 & 33.30 & 58.20 \\
\hline $43 X-4,29-31$ & 402.4 & 2.78 & 1.81 & 1.26 & 1.24 & 30.24 & 55.43 \\
\hline $44 \mathrm{X}-2,29-31$ & 409.0 & 2.68 & 1.60 & 0.96 & 1.88 & 40.28 & 65.33 \\
\hline $44 X-4,29-31$ & 412.0 & 2.51 & 1.58 & 0.96 & 1.69 & 39.32 & 62.84 \\
\hline $45 X-2,29-31$ & 418.6 & 2.73 & 1.67 & 1.05 & 1.66 & 36.89 & 62.40 \\
\hline $45 X-4,29-31$ & 421.6 & 2.62 & 1.71 & 1.15 & 1.32 & 32.76 & 56.86 \\
\hline $45 X-6,29-31$ & 424.5 & 2.72 & 1.73 & 1.16 & 1.41 & 33.32 & 58.45 \\
\hline $46 \mathrm{X}-2,29-31$ & 427.5 & 2.76 & 1.79 & 1.24 & 1.27 & 30.94 & 56.04 \\
\hline $46 \mathrm{X}-4,29-31$ & 430.5 & 2.62 & 1.75 & 1.21 & 1.20 & 30.76 & 54.56 \\
\hline $46 \mathrm{X}-6,23-25$ & 433.3 & 2.93 & 1.76 & 1.15 & 1.61 & 34.61 & 61.68 \\
\hline $47 X-2,29-31$ & 437.8 & 2.52 & 1.53 & 0.87 & 1.98 & 42.97 & 66.49 \\
\hline $47 X-4,29-31$ & 440.8 & 2.56 & 1.54 & 0.89 & 1.98 & 42.56 & 66.47 \\
\hline $48 \mathrm{X}-2,29-31$ & 447.4 & 2.74 & 1.76 & 1.20 & 1.33 & 32.06 & 57.16 \\
\hline $48 \mathrm{X}-4,29-31$ & 450.4 & 2.64 & 1.77 & 1.23 & 1.18 & 30.31 & 54.20 \\
\hline $49 X-2,29-31$ & 456.9 & 2.71 & 1.62 & 0.97 & 1.86 & 39.78 & 65.07 \\
\hline $49 X-4,29-31$ & 459.9 & 2.62 & 1.74 & 1.20 & 1.23 & 31.26 & 55.19 \\
\hline $50 X-2,29-31$ & 467.0 & 2.72 & 1.77 & 1.22 & 1.28 & 31.33 & 56.19 \\
\hline $50 X-5,29-31$ & 471.5 & 2.68 & 1.62 & 0.98 & 1.83 & 39.53 & 64.63 \\
\hline $51 X-2,29-31$ & 476.7 & 2.54 & 1.65 & 1.07 & 1.42 & 35.08 & 58.67 \\
\hline $51 X-5,29-31$ & 481.1 & 2.83 & 1.74 & 1.13 & 1.56 & 34.65 & 60.88 \\
\hline $52 X-2,29-31$ & 484.9 & 2.67 & 1.75 & 1.19 & 1.29 & 31.76 & 56.24 \\
\hline $52 X-6,29-31$ & 490.8 & 2.71 & 1.75 & 1.18 & 1.34 & 32.34 & 57.26 \\
\hline
\end{tabular}


Table T19 (continued).

\begin{tabular}{|c|c|c|c|c|c|c|c|}
\hline \multirow{2}{*}{$\begin{array}{l}\text { Core, section, } \\
\text { interval }(\mathrm{cm})\end{array}$} & \multirow{2}{*}{$\begin{array}{l}\text { Depth } \\
\text { (mbsf) }\end{array}$} & \multicolumn{3}{|c|}{ Density $\left(\mathrm{g} / \mathrm{cm}^{3}\right)$} & \multirow{2}{*}{$\begin{array}{l}\text { Void } \\
\text { ratio }\end{array}$} & \multirow{2}{*}{$\begin{array}{c}\text { Water } \\
\text { content } \\
(\%)\end{array}$} & \multirow{2}{*}{$\begin{array}{c}\text { Porosity } \\
\text { (\%) }\end{array}$} \\
\hline & & Dry grain & Wet bulk & Dry bulk & & & \\
\hline $53 X-2,29-31$ & 495.0 & 2.73 & 1.81 & 1.27 & 1.18 & 29.64 & 54.21 \\
\hline $53 X-5,29-31$ & 501.0 & 2.62 & 1.76 & 1.23 & 1.17 & 30.27 & 53.97 \\
\hline $54 X-2,29-31$ & 504.7 & 2.66 & 1.63 & 1.00 & 1.73 & 38.38 & 63.31 \\
\hline $54 X-6,29-31$ & 510.7 & 2.56 & 1.71 & 1.16 & 1.25 & 32.07 & 55.53 \\
\hline $55 X-2,29-31$ & 514.2 & 2.80 & 1.72 & 1.12 & 1.57 & 35.03 & 61.04 \\
\hline $55 X-6,29-31$ & 520.2 & 2.63 & 1.70 & 1.13 & 1.38 & 33.72 & 58.07 \\
\hline $56 X-2,29-31$ & 523.8 & 2.66 & 1.66 & 1.06 & 1.58 & 36.36 & 61.18 \\
\hline $56 X-6,29-31$ & 529.3 & 2.78 & 1.82 & 1.28 & 1.22 & 29.87 & 55.02 \\
\hline $57 X-2,29-31$ & 535.0 & 2.58 & 1.62 & 1.02 & 1.61 & 37.49 & 61.62 \\
\hline $57 X-5,29-31$ & 539.5 & 2.45 & 1.63 & 1.07 & 1.35 & 34.72 & 57.38 \\
\hline $58 X-2,34-36$ & 543.1 & 2.76 & 1.79 & 1.23 & 1.29 & 31.15 & 56.33 \\
\hline $58 X-6,34-36$ & 548.7 & 2.57 & 1.63 & 1.03 & 1.55 & 36.72 & 60.74 \\
\hline $59 \times-2,29-31$ & 552.7 & 2.79 & 1.82 & 1.27 & 1.24 & 30.09 & 55.32 \\
\hline $59 X-4,29-31$ & 555.7 & 2.69 & 1.81 & 1.29 & 1.13 & 28.92 & 53.00 \\
\hline $59 X-6,29-31$ & 557.9 & 2.72 & 1.80 & 1.26 & 1.19 & 29.81 & 54.32 \\
\hline $60 \times-2,29-31$ & 562.3 & 2.71 & 1.78 & 1.23 & 1.24 & 30.80 & 55.46 \\
\hline $60 \times-4,29-31$ & 565.3 & 2.48 & 1.56 & 0.94 & 1.71 & 39.87 & 63.09 \\
\hline $61 X-2,29-31$ & 571.7 & 2.76 & 1.79 & 1.24 & 1.28 & 31.01 & 56.18 \\
\hline $61 X-4,29-31$ & 574.7 & 2.54 & 1.64 & 1.05 & 1.48 & 35.95 & 59.67 \\
\hline $61 X-6,29-31$ & 577.7 & 2.69 & 1.77 & 1.22 & 1.25 & 30.95 & 55.48 \\
\hline $62 X-2,29-31$ & 580.5 & 2.52 & 1.57 & 0.94 & 1.76 & 40.12 & 63.77 \\
\hline $62 X-4,29-31$ & 583.5 & 2.65 & 1.74 & 1.19 & 1.27 & 31.68 & 55.88 \\
\hline $62 X-6,29-31$ & 586.5 & 2.73 & 1.75 & 1.18 & 1.37 & 32.72 & 57.85 \\
\hline $63 X-2,29-31$ & 591.2 & 2.57 & 1.41 & 0.67 & 3.06 & 52.81 & 75.35 \\
\hline $63 X-4,29-31$ & 594.2 & 2.74 & 1.73 & 1.14 & 1.46 & 33.93 & 59.34 \\
\hline $64 X-2,29-31$ & 599.8 & 2.62 & 1.63 & 1.01 & 1.65 & 37.80 & 62.32 \\
\hline $64 X-4,29-31$ & 602.7 & 2.45 & 1.60 & 1.01 & 1.50 & 37.07 & 59.95 \\
\hline $64 X-6,29-31$ & 605.7 & 2.62 & 1.65 & 1.04 & 1.58 & 36.80 & 61.27 \\
\hline $65 X-2,29-31$ & 610.3 & 2.56 & 1.63 & 1.03 & 1.56 & 36.96 & 60.86 \\
\hline $65 X-4,29-31$ & 613.5 & 2.24 & 1.57 & 1.03 & 1.22 & 34.52 & 54.94 \\
\hline $65 X-6,29-31$ & 616.3 & 2.66 & 1.71 & 1.14 & 1.39 & 33.54 & 58.14 \\
\hline $68 X-2,29-31$ & 638.0 & 2.56 & 1.66 & 1.07 & 1.45 & 35.28 & 59.14 \\
\hline $68 X-4,29-31$ & 641.0 & 2.67 & 1.76 & 1.22 & 1.24 & 31.07 & 55.45 \\
\hline $70 \times-2,29-31$ & 658.3 & 2.55 & 1.60 & 0.99 & 1.64 & 38.32 & 62.19 \\
\hline $70 X-4,29-31$ & 661.3 & 2.62 & 1.63 & 1.02 & 1.63 & 37.53 & 62.04 \\
\hline $70 X-6,29-31$ & 664.3 & 2.57 & 1.74 & 1.21 & 1.16 & 30.43 & 53.69 \\
\hline $71 X-2,29-31$ & 667.2 & 2.75 & 1.76 & 1.18 & 1.37 & 32.58 & 57.88 \\
\hline $71 X-4,29-31$ & 669.3 & 2.48 & 1.56 & 0.94 & 1.71 & 39.94 & 63.16 \\
\hline $71 X-6,29-31$ & 672.3 & 2.62 & 1.65 & 1.05 & 1.55 & 36.34 & 60.84 \\
\hline $72 X-5,29-31$ & 681.6 & 2.60 & 1.65 & 1.05 & 1.54 & 36.36 & 60.67 \\
\hline $73 X-2,29-31$ & 686.0 & 2.75 & 1.83 & 1.31 & 1.14 & 28.71 & 53.30 \\
\hline $73 \times-5,29-31$ & 690.5 & 2.74 & 1.81 & 1.28 & 1.19 & 29.60 & 54.30 \\
\hline $74 X-2,29-31$ & 696.6 & 2.64 & 1.65 & 1.05 & 1.57 & 36.51 & 61.13 \\
\hline $74 X-6,29-31$ & 702.6 & 2.55 & 1.57 & 0.94 & 1.81 & 40.49 & 64.39 \\
\hline $75 X-2,29-31$ & 706.2 & 2.64 & 1.72 & 1.15 & 1.35 & 33.07 & 57.42 \\
\hline $75 X-6,29-31$ & 711.7 & 2.64 & 1.65 & 1.04 & 1.61 & 36.94 & 61.63 \\
\hline $76 X-2,39-41$ & 716.0 & 2.50 & 1.54 & 0.89 & 1.90 & 42.06 & 65.47 \\
\hline $76 X-4,39-41$ & 721.5 & 2.55 & 1.58 & 0.95 & 1.74 & 39.67 & 63.52 \\
\hline $77 X-3,29-31$ & 725.9 & 2.76 & 1.80 & 1.26 & 1.24 & 30.30 & 55.33 \\
\hline $77 X-6,29-31$ & 730.4 & 2.53 & 1.59 & 0.98 & 1.65 & 38.60 & 62.26 \\
\hline $78 X-2,29-31$ & 735.1 & 2.52 & 1.51 & 0.85 & 2.08 & 44.08 & 67.52 \\
\hline $78 X-4,29-31$ & 738.1 & 2.60 & 1.69 & 1.11 & 1.39 & 34.06 & 58.11 \\
\hline $79 \times-2,29-31$ & 740.9 & 2.67 & 1.74 & 1.18 & 1.30 & 32.08 & 56.61 \\
\hline $79 \times-5,29-31$ & 745.4 & 2.35 & 1.64 & 1.11 & 1.16 & 32.43 & 53.72 \\
\hline
\end{tabular}


Table T20. Affine table indicating the amount that each core in each hole needs to be offset in order to construct a continuous record, Site U1344. (See table note.) (Continued on next two pages.)

\begin{tabular}{|c|c|c|c|c|c|c|c|}
\hline \multirow[b]{2}{*}{ Core } & \multicolumn{2}{|c|}{ Depth (mbsf) } & \multirow{2}{*}{$\begin{array}{l}\text { Offset } \\
(\mathrm{m})\end{array}$} & \multicolumn{2}{|c|}{ Depth CCSF-A (m) } & \multirow{2}{*}{$\begin{array}{l}\text { Recovered } \\
(\mathrm{m})\end{array}$} & \multirow{2}{*}{$\begin{array}{c}\text { Recovery } \\
\text { (\%) }\end{array}$} \\
\hline & Top & Bottom & & Top & Bottom & & \\
\hline \multicolumn{8}{|c|}{ 323-U1344A- } \\
\hline $1 \mathrm{H}$ & 0.00 & 9.14 & 0.00 & 0.00 & 9.14 & 9.14 & 100 \\
\hline $2 \mathrm{H}$ & 9.10 & 18.75 & 0.80 & 9.90 & 19.55 & 9.65 & 102 \\
\hline $3 \mathrm{H}$ & 18.60 & 28.72 & 2.01 & 20.61 & 30.73 & 10.12 & 107 \\
\hline $4 \mathrm{H}$ & 28.10 & 38.22 & 3.86 & 31.96 & 42.08 & 10.12 & 107 \\
\hline $5 \mathrm{H}$ & 37.60 & 47.61 & 5.93 & 43.53 & 53.54 & 10.01 & 105 \\
\hline $6 \mathrm{H}$ & 47.10 & 57.29 & 7.64 & 54.74 & 64.93 & 10.19 & 107 \\
\hline $7 \mathrm{H}$ & 56.60 & 66.68 & 7.66 & 64.26 & 74.34 & 10.08 & 106 \\
\hline $8 \mathrm{H}$ & 66.10 & 75.32 & 9.36 & 75.46 & 84.68 & 9.22 & 97 \\
\hline $9 \mathrm{H}$ & 75.60 & 85.21 & 12.11 & 87.71 & 97.32 & 9.61 & 101 \\
\hline $10 \mathrm{H}$ & 85.10 & 95.19 & 13.20 & 98.30 & 108.39 & 10.09 & 106 \\
\hline $11 \mathrm{H}$ & 94.60 & 104.46 & 14.22 & 108.82 & 118.68 & 9.86 & 104 \\
\hline $12 \mathrm{H}$ & 104.10 & 113.96 & 16.13 & 120.23 & 130.09 & 9.86 & 104 \\
\hline $13 \mathrm{H}$ & 113.60 & 123.49 & 18.69 & 132.29 & 142.18 & 9.89 & 104 \\
\hline $14 \mathrm{H}$ & 123.10 & 132.89 & 20.81 & 143.91 & 153.70 & 9.79 & 103 \\
\hline $15 \mathrm{H}$ & 132.60 & 142.45 & 22.79 & 155.39 & 165.24 & 9.85 & 104 \\
\hline $16 \mathrm{H}$ & 142.10 & 152.23 & 24.67 & 166.77 & 176.90 & 10.13 & 107 \\
\hline $17 \mathrm{H}$ & 151.60 & 161.27 & 26.19 & 177.79 & 187.46 & 9.67 & 102 \\
\hline $18 \mathrm{H}$ & 161.10 & 171.34 & 27.91 & 189.02 & 199.26 & 10.24 & 108 \\
\hline $19 \mathrm{H}$ & 170.60 & 180.17 & 30.52 & 201.12 & 210.69 & 9.57 & 101 \\
\hline $20 \mathrm{H}$ & 180.10 & 190.40 & 32.30 & 212.40 & 222.70 & 10.30 & 108 \\
\hline $21 \mathrm{H}$ & 189.60 & 199.28 & 34.74 & 224.34 & 234.02 & 9.68 & 102 \\
\hline $22 \mathrm{H}$ & 199.10 & 208.83 & 35.85 & 234.95 & 244.68 & 9.73 & 102 \\
\hline $23 \mathrm{H}$ & 208.60 & 218.11 & 38.70 & 247.30 & 256.81 & 9.51 & 100 \\
\hline $24 \mathrm{H}$ & 218.10 & 226.67 & 38.61 & 256.71 & 265.28 & 8.57 & 101 \\
\hline $25 \mathrm{H}$ & 226.60 & 236.10 & 38.21 & 264.81 & 274.31 & 9.50 & 100 \\
\hline $26 \mathrm{H}$ & 236.10 & 245.49 & 40.54 & 276.64 & 286.03 & 9.39 & 99 \\
\hline $27 \mathrm{H}$ & 245.60 & 255.83 & 42.04 & 287.64 & 297.87 & 10.23 & 108 \\
\hline $28 \mathrm{X}$ & 255.10 & 263.83 & 43.06 & 298.16 & 306.89 & 8.73 & 103 \\
\hline $29 x$ & 263.60 & 270.35 & 44.06 & 307.66 & 314.41 & 6.75 & 70 \\
\hline $30 x$ & 273.20 & 280.31 & 43.18 & 316.38 & 323.49 & 7.11 & 74 \\
\hline $31 x$ & 282.80 & 288.58 & 43.78 & 326.58 & 332.36 & 5.78 & 60 \\
\hline $32 x$ & 292.40 & 299.17 & 43.78 & 336.18 & 342.95 & 6.77 & 71 \\
\hline $33 x$ & 302.00 & 309.23 & 43.78 & 345.78 & 353.01 & 7.23 & 75 \\
\hline $34 X$ & 311.60 & 318.41 & 43.78 & 355.38 & 362.19 & 6.81 & 73 \\
\hline $35 X$ & 320.90 & 323.57 & 43.78 & 364.68 & 367.35 & 2.67 & 28 \\
\hline $36 \mathrm{X}$ & 330.40 & 338.89 & 43.78 & 374.18 & 382.67 & 8.49 & 88 \\
\hline $37 X$ & 340.00 & 346.38 & 43.78 & 383.78 & 390.16 & 6.38 & 66 \\
\hline $38 \mathrm{X}$ & 349.60 & 357.08 & 43.78 & 393.38 & 400.86 & 7.48 & 78 \\
\hline $39 x$ & 359.20 & 364.23 & 43.78 & 402.98 & 408.01 & 5.03 & 52 \\
\hline $40 x$ & 368.80 & 373.19 & 43.78 & 412.58 & 416.97 & 4.39 & 45 \\
\hline $41 X$ & 378.50 & 387.97 & 43.78 & 422.28 & 431.75 & 9.47 & 100 \\
\hline $42 X$ & 388.00 & 397.51 & 43.78 & 431.78 & 441.29 & 9.51 & 99 \\
\hline $43 X$ & 397.60 & 403.56 & 43.78 & 441.38 & 447.34 & 5.96 & 62 \\
\hline $44 X$ & 407.20 & 414.98 & 43.78 & 450.98 & 458.76 & 7.78 & 81 \\
\hline $45 X$ & 416.80 & 425.93 & 43.78 & 460.58 & 469.71 & 9.13 & 95 \\
\hline $46 \mathrm{X}$ & 426.40 & 434.10 & 43.78 & 470.18 & 477.88 & 7.70 & 80 \\
\hline $47 X$ & 436.00 & 443.02 & 43.78 & 479.78 & 486.80 & 7.02 & 73 \\
\hline $48 \mathrm{X}$ & 445.60 & 451.69 & 43.78 & 489.38 & 495.47 & 6.09 & 64 \\
\hline $49 x$ & 455.10 & 461.85 & 43.78 & 498.88 & 505.63 & 6.75 & 70 \\
\hline $50 X$ & 464.70 & 473.49 & 43.78 & 508.48 & 517.27 & 8.79 & 91 \\
\hline $51 X$ & 474.40 & 482.67 & 43.78 & 518.18 & 526.45 & 8.27 & 87 \\
\hline $52 X$ & 483.90 & 493.20 & 43.78 & 527.68 & 536.98 & 9.30 & 100 \\
\hline $53 X$ & 493.20 & 502.13 & 43.78 & 536.98 & 545.91 & 8.93 & 92 \\
\hline $54 X$ & 502.90 & 511.96 & 43.78 & 546.68 & 555.74 & 9.06 & 95 \\
\hline $55 X$ & 512.40 & 521.80 & 43.78 & 556.18 & 565.58 & 9.40 & 98 \\
\hline $56 \mathrm{X}$ & 522.00 & 530.31 & 43.78 & 565.78 & 574.09 & 8.31 & 86 \\
\hline $57 X$ & 531.70 & 540.28 & 43.78 & 575.48 & 584.06 & 8.58 & 89 \\
\hline $58 X$ & 541.30 & 549.57 & 43.78 & 585.08 & 593.35 & 8.27 & 86 \\
\hline $59 X$ & 550.90 & 558.79 & 43.78 & 594.68 & 602.57 & 7.89 & 82 \\
\hline $60 x$ & 560.50 & 567.42 & 43.78 & 604.28 & 611.20 & 6.92 & 72 \\
\hline $61 X$ & 570.10 & 578.90 & 43.78 & 613.88 & 622.68 & 8.80 & 91 \\
\hline $62 X$ & 579.80 & 587.61 & 43.78 & 623.58 & 631.39 & 7.81 & 81 \\
\hline $63 x$ & 589.40 & 596.29 & 43.78 & 633.18 & 640.07 & 6.89 & 72 \\
\hline $64 X$ & 599.00 & 607.73 & 43.78 & 642.78 & 651.51 & 8.73 & 92 \\
\hline $65 x$ & 608.50 & 618.08 & 43.78 & 652.28 & 661.86 & 9.58 & 100 \\
\hline $66 \mathrm{X}$ & 618.10 & 618.10 & 43.78 & 661.88 & 661.88 & - & 0 \\
\hline
\end{tabular}


Table T20 (continued). (Continued on next page.)

\begin{tabular}{|c|c|c|c|c|c|c|c|}
\hline \multirow[b]{2}{*}{ Core } & \multicolumn{2}{|c|}{ Depth (mbsf) } & \multirow{2}{*}{$\begin{array}{l}\text { Offset } \\
(\mathrm{m})\end{array}$} & \multicolumn{2}{|c|}{ Depth CCSF-A (m) } & \multirow{2}{*}{$\begin{array}{l}\text { Recovered } \\
\text { (m) }\end{array}$} & \multirow{2}{*}{$\begin{array}{c}\text { Recovery } \\
(\%)\end{array}$} \\
\hline & Top & Bottom & & Top & Bottom & & \\
\hline $67 X$ & 627.70 & 627.70 & 43.78 & 671.48 & 671.48 & - & 0 \\
\hline $68 \mathrm{X}$ & 637.30 & 646.00 & 43.78 & 681.08 & 689.78 & 8.70 & 91 \\
\hline $69 \mathrm{X}$ & 646.90 & 647.34 & 43.78 & 690.68 & 691.12 & 0.44 & 5 \\
\hline $70 x$ & 656.50 & 666.45 & 43.78 & 700.28 & 710.23 & 9.95 & 104 \\
\hline $71 x$ & 666.10 & 675.18 & 43.78 & 709.88 & 718.96 & 9.08 & 95 \\
\hline $72 \mathrm{X}$ & 675.70 & 683.55 & 43.78 & 719.48 & 727.33 & 7.85 & 82 \\
\hline $73 x$ & 685.30 & 694.70 & 43.78 & 729.08 & 738.48 & 9.40 & 98 \\
\hline $74 X$ & 694.90 & 703.69 & 43.78 & 738.68 & 747.47 & 8.79 & 92 \\
\hline $75 \mathrm{X}$ & 704.50 & 713.35 & 43.78 & 748.28 & 757.13 & 8.85 & 92 \\
\hline $76 \mathrm{X}$ & 714.10 & 723.11 & 43.78 & 757.88 & 766.89 & 9.01 & 94 \\
\hline $77 X$ & 723.70 & 733.13 & 43.78 & 767.48 & 776.91 & 9.43 & 98 \\
\hline $78 \mathrm{X}$ & 733.30 & 739.75 & 43.78 & 777.08 & 783.53 & 6.45 & 113 \\
\hline $79 \mathrm{X}$ & 739.00 & 746.59 & 43.78 & 782.78 & 790.37 & 7.59 & 126 \\
\hline \multicolumn{8}{|c|}{ 323-U1344B- } \\
\hline $1 \mathrm{H}$ & 0.00 & 4.80 & -0.04 & -0.04 & 4.76 & 4.80 & 100 \\
\hline \multicolumn{8}{|c|}{ 323-U1344C- } \\
\hline $1 \mathrm{H}$ & 0.00 & 7.12 & 0.04 & 0.04 & 7.16 & 7.12 & 100 \\
\hline $2 \mathrm{H}$ & 7.10 & 14.24 & 1.26 & 8.36 & 15.50 & 7.14 & 75 \\
\hline $3 \mathrm{H}$ & 16.60 & 26.40 & 2.70 & 19.30 & 29.10 & 9.80 & 103 \\
\hline $4 \mathrm{H}$ & 26.10 & 35.55 & 3.66 & 29.76 & 39.21 & 9.45 & 99 \\
\hline \multicolumn{8}{|c|}{ 323-U1344D- } \\
\hline $1 \mathrm{H}$ & 0.00 & 2.73 & -0.02 & -0.02 & 2.71 & 2.73 & 101 \\
\hline $2 \mathrm{H}$ & 2.70 & 12.25 & 2.20 & 4.90 & 14.45 & 9.55 & 101 \\
\hline $3 \mathrm{H}$ & 12.20 & 21.62 & 2.84 & 15.04 & 24.46 & 9.42 & 99 \\
\hline $4 \mathrm{H}$ & 21.70 & 31.67 & 3.80 & 25.50 & 35.47 & 9.97 & 105 \\
\hline $5 \mathrm{H}$ & 31.20 & 38.31 & 5.12 & 36.32 & 43.43 & 7.11 & 75 \\
\hline $6 \mathrm{H}$ & 40.70 & 50.21 & 8.16 & 48.86 & 58.37 & 9.51 & 100 \\
\hline $7 \mathrm{H}$ & 50.20 & 59.76 & 9.95 & 60.15 & 69.71 & 9.56 & 101 \\
\hline $8 \mathrm{H}$ & 59.70 & 66.51 & 9.67 & 69.37 & 76.18 & 6.81 & 72 \\
\hline $9 \mathrm{H}$ & 69.20 & 78.37 & 12.03 & 81.23 & 90.40 & 9.17 & 97 \\
\hline $10 \mathrm{H}$ & 78.70 & 88.54 & 13.26 & 91.96 & 101.80 & 9.84 & 104 \\
\hline $11 \mathrm{H}$ & 88.20 & 97.86 & 14.53 & 102.73 & 112.39 & 9.66 & 102 \\
\hline $12 \mathrm{H}$ & 97.70 & 107.37 & 17.37 & 115.07 & 124.74 & 9.67 & 102 \\
\hline $13 \mathrm{H}$ & 107.20 & 116.70 & 19.27 & 126.47 & 135.97 & 9.50 & 100 \\
\hline $14 \mathrm{H}$ & 116.70 & 126.38 & 21.29 & 137.99 & 147.67 & 9.68 & 102 \\
\hline $15 \mathrm{H}$ & 126.20 & 135.77 & 23.53 & 149.73 & 159.30 & 9.57 & 101 \\
\hline $16 \mathrm{H}$ & 135.70 & 145.40 & 25.00 & 160.70 & 170.40 & 9.70 & 102 \\
\hline $17 \mathrm{H}$ & 145.20 & 155.12 & 26.51 & 171.71 & 181.63 & 9.92 & 104 \\
\hline $18 \mathrm{H}$ & 154.70 & 164.39 & 28.21 & 182.91 & 192.60 & 9.69 & 102 \\
\hline $19 \mathrm{H}$ & 164.20 & 174.41 & 30.13 & 194.33 & 204.54 & 10.21 & 107 \\
\hline $20 \mathrm{H}$ & 173.70 & 183.08 & 31.43 & 205.13 & 214.51 & 9.38 & 99 \\
\hline $21 \mathrm{H}$ & 183.20 & 192.93 & 34.78 & 217.98 & 227.71 & 9.73 & 102 \\
\hline $22 \mathrm{H}$ & 192.70 & 201.89 & 37.45 & 230.15 & 239.34 & 9.19 & 97 \\
\hline $23 \mathrm{H}$ & 202.20 & 211.24 & 38.41 & 240.61 & 249.65 & 9.04 & 95 \\
\hline $24 \mathrm{H}$ & 211.70 & 221.15 & 40.92 & 252.60 & 262.05 & 9.45 & 99 \\
\hline $25 \mathrm{H}$ & 221.20 & 224.51 & 41.02 & 262.22 & 265.53 & 3.31 & 100 \\
\hline $26 \mathrm{H}$ & 224.50 & 234.09 & 40.49 & 264.99 & 274.58 & 9.59 & 101 \\
\hline $27 \mathrm{H}$ & 234.00 & 240.72 & 39.55 & 273.55 & 280.27 & 6.72 & 134 \\
\hline $28 \mathrm{H}$ & 239.00 & 248.38 & 42.01 & 281.01 & 290.39 & 9.38 & 99 \\
\hline $29 \mathrm{H}$ & 248.50 & 258.41 & 43.85 & 292.35 & 302.26 & 9.91 & 104 \\
\hline $30 \mathrm{H}$ & 258.00 & 267.40 & 45.49 & 303.49 & 312.89 & 9.40 & 99 \\
\hline $31 \mathrm{H}$ & 267.50 & 277.96 & 44.41 & 311.91 & 322.37 & 10.46 & 110 \\
\hline $32 \mathrm{H}$ & 277.00 & 286.27 & 45.42 & 322.42 & 331.69 & 9.27 & 98 \\
\hline \multicolumn{8}{|c|}{ 323-U1344E- } \\
\hline $1 \mathrm{H}$ & 0.00 & 5.34 & 0.28 & 0.28 & 5.62 & 5.34 & 101 \\
\hline $2 \mathrm{H}$ & 5.30 & 15.02 & 3.11 & 8.41 & 18.13 & 9.72 & 102 \\
\hline $3 \mathrm{H}$ & 14.80 & 24.85 & 4.15 & 18.95 & 29.00 & 10.05 & 106 \\
\hline $4 \mathrm{H}$ & 24.30 & 34.68 & 5.37 & 29.67 & 40.05 & 10.38 & 109 \\
\hline $5 \mathrm{H}$ & 33.80 & 43.82 & 7.31 & 41.11 & 51.13 & 10.02 & 105 \\
\hline $6 \mathrm{H}$ & 43.30 & 53.38 & 8.67 & 51.97 & 62.05 & 10.08 & 106 \\
\hline $7 \mathrm{H}$ & 52.80 & 62.10 & 11.33 & 64.13 & 73.43 & 9.30 & 98 \\
\hline $8 \mathrm{H}$ & 62.30 & 72.05 & 10.20 & 72.50 & 82.25 & 9.75 & 103 \\
\hline $9 \mathrm{H}$ & 71.80 & 81.37 & 11.98 & 83.78 & 93.35 & 9.57 & 101 \\
\hline $10 \mathrm{H}$ & 81.30 & 90.85 & 13.21 & 94.51 & 104.06 & 9.55 & 101 \\
\hline 11D & 90.80 & 90.80 & 13.21 & 104.01 & 104.01 & - & 0 \\
\hline $12 \mathrm{H}$ & 93.80 & 103.05 & 16.42 & 110.22 & 119.47 & 9.25 & 97 \\
\hline $13 \mathrm{H}$ & 103.30 & 112.90 & 18.56 & 121.86 & 131.46 & 9.60 & 101 \\
\hline
\end{tabular}


Table T20 (continued).

\begin{tabular}{|c|c|c|c|c|c|c|c|}
\hline \multirow[b]{2}{*}{ Core } & \multicolumn{2}{|c|}{ Depth (mbsf) } & \multirow{2}{*}{$\begin{array}{l}\text { Offset } \\
(\mathrm{m})\end{array}$} & \multicolumn{2}{|c|}{ Depth CCSF-A (m) } & \multirow{2}{*}{$\begin{array}{l}\text { Recovered } \\
\quad(\mathrm{m})\end{array}$} & \multirow{2}{*}{$\begin{array}{c}\text { Recovery } \\
\text { (\%) }\end{array}$} \\
\hline & Top & Bottom & & Top & Bottom & & \\
\hline $14 \mathrm{H}$ & 112.80 & 122.46 & 19.43 & 132.23 & 141.89 & 9.66 & 102 \\
\hline $15 \mathrm{H}$ & 122.30 & 127.10 & 21.18 & 143.48 & 148.28 & 4.80 & 107 \\
\hline $16 \mathrm{H}$ & 126.80 & 136.51 & 23.44 & 150.24 & 159.95 & 9.71 & 102 \\
\hline $17 \mathrm{H}$ & 136.30 & 145.03 & 26.81 & 163.11 & 171.84 & 8.73 & 92 \\
\hline $18 \mathrm{H}$ & 145.80 & 155.49 & 26.81 & 172.61 & 182.30 & 9.69 & 102 \\
\hline $19 \mathrm{H}$ & 155.30 & 165.44 & 28.92 & 184.22 & 194.36 & 10.14 & 107 \\
\hline $20 \mathrm{H}$ & 164.80 & 174.28 & 30.74 & 195.54 & 205.02 & 9.48 & 100 \\
\hline $21 \mathrm{H}$ & 174.30 & 182.62 & 33.00 & 207.30 & 215.62 & 8.32 & 88 \\
\hline $22 \mathrm{H}$ & 183.80 & 193.85 & 34.87 & 218.67 & 228.72 & 10.05 & 106 \\
\hline $23 \mathrm{H}$ & 193.30 & 202.79 & 36.74 & 230.04 & 239.53 & 9.49 & 100 \\
\hline
\end{tabular}

Note: $-=$ not applicable . 
Table T21. Splice table indicating tie points between holes, Site U1344. Sampling along the splice should be used to construct a continuous record.

\begin{tabular}{|c|c|c|c|c|c|c|}
\hline \multirow[b]{2}{*}{$\begin{array}{l}\text { Hole, core, section, } \\
\text { interval }(\mathrm{cm})\end{array}$} & \multicolumn{2}{|c|}{ Depth } & & \multirow[b]{2}{*}{$\begin{array}{l}\text { Hole, core, section, } \\
\text { interval }(\mathrm{cm})\end{array}$} & \multicolumn{2}{|c|}{ Depth } \\
\hline & mbsf & $\begin{array}{l}\text { CCSF-D } \\
(\mathrm{m})\end{array}$ & & & mbsf & $\begin{array}{l}\text { CCSF-D } \\
(\mathrm{m})\end{array}$ \\
\hline $323-$ & & & & $323-$ & & \\
\hline U1344A-1H-5, 119.9 & 7.20 & 7.20 & Tie to & U1344 D-2H-2, 80.0 & 5.00 & 7.20 \\
\hline U1344D-2H-6, 9.6 & 10.30 & 12.50 & Tie to & U1344 A-2H-2, 109.9 & 11.70 & 12.50 \\
\hline U1344A-2H-5, 72.1 & 15.82 & 16.62 & Tie to & U1344 D-3H-2, 8.0 & 13.78 & 16.62 \\
\hline U1344D-3H-6, 87.4 & 20.57 & 23.41 & Tie to & U1344 A-3H-2, 130.2 & 21.40 & 23.41 \\
\hline U1344A-3H-7, 46.6 & 28.07 & 30.08 & Tie to & U1344 E-4H-2, 1.3 & 24.70 & 30.08 \\
\hline U1344E-4H-7, 29.8 & 32.49 & 37.86 & Tie to & U1344 D-5H-1, 153.7 & 32.74 & 37.86 \\
\hline U1344D-5H-4, 114.6 & 36.85 & 41.97 & Tie to & U1344 E-5H-2, 48.3 & 34.66 & 41.97 \\
\hline U1344E-5H-6, 107.1 & 41.25 & 48.56 & Tie to & U1344 A-5H-5, 2.7 & 42.63 & 48.56 \\
\hline U1344A-5H-7, 42.0 & 46.03 & 51.96 & Tie to & U1344 D-6H-3, 79.9 & 43.80 & 51.96 \\
\hline U1344D-6H-5, 28.7 & 46.29 & 54.45 & Tie to & U1344 E-6H-2, 119.1 & 45.78 & 54.45 \\
\hline U1344E-6H-6, 112.5 & 51.71 & 60.38 & Tie to & U1344 A-6H-4, 122.3 & 52.74 & 60.38 \\
\hline U1344A-6H-6, 130.4 & 55.78 & 63.42 & Tie to & U1344 D-7H-3, 27.4 & 53.47 & 63.42 \\
\hline U1344D-7H-5, 84.5 & 56.95 & 66.89 & Tie to & U1344 A-7H-2, 153.1 & 59.23 & 66.89 \\
\hline U1344A-7H-7, 50.7 & 65.71 & 73.37 & Tie to & U1344 E-8H-2, 52.3 & 63.17 & 73.37 \\
\hline U1344E-8H-7, 82.3 & 70.90 & 81.10 & Tie to & U1344 A-8H-5, 79.4 & 71.74 & 81.10 \\
\hline U1344A-8H-7, 20.1 & 74.13 & 83.49 & Tie to & U1344 D-9H-3, 23.0 & 71.46 & 83.49 \\
\hline U1344D-9H-6, 64.7 & 76.31 & 88.33 & Tie to & U1344 E-9H-4, 70.3 & 76.35 & 88.33 \\
\hline U1344E-9H-6, 145.9 & 80.07 & 92.05 & Tie to & U1344 A-9H-4, 74.3 & 79.94 & 92.05 \\
\hline U1344A-9H-7, 8.2 & 83.75 & 95.86 & Tie to & U1344 D-10H-4, 32.9 & 82.60 & 95.86 \\
\hline U1344D-10H-7, 45.1 & 87.10 & 100.36 & Tie to & U1344 A-10H-2, 78.4 & 87.16 & 100.36 \\
\hline U1344A-10H-6, 113.7 & 93.49 & 106.69 & Tie to & U1344 D-11H-4, 45.4 & 92.15 & 106.69 \\
\hline U1344D-11H-6, 133.4 & 95.74 & 110.28 & Tie to & U1344 A-11H-2, 86.6 & 96.06 & 110.28 \\
\hline U1344A-11H-7, 20.3 & 102.75 & 116.97 & Tie to & U1344 D-12H-2, 62.0 & 99.60 & 116.97 \\
\hline U1344D-12H-6, 64.1 & 105.17 & 122.54 & Tie to & U1344 E-13H-1, 68.1 & 103.98 & 122.54 \\
\hline U1344E-13H-6, 149.3 & 111.42 & 129.99 & Tie to & U1344 D-13H-4, 24.6 & 110.72 & 129.99 \\
\hline U1344D-13H-7, 53.7 & 115.27 & 134.54 & Tie to & U1344 E-14H-3, 17.3 & 115.10 & 134.54 \\
\hline U1344E-14H-7, 12.4 & 120.98 & 140.42 & Tie to & U1344 D-14H-2, 139.2 & 119.13 & 140.42 \\
\hline U1344D-14H-6, 124.0 & 124.73 & 146.02 & Tie to & U1344 A-14H-2, 139.9 & 125.21 & 146.02 \\
\hline U1344A-14H-7, 56.5 & 131.64 & 152.45 & Tie to & U1344 E-16H-2, 124.0 & 129.01 & 152.45 \\
\hline U1344E-16H-8, 62.4 & 135.69 & 159.14 & Tie to & U1344 A-15H-3, 137.8 & 136.35 & 159.14 \\
\hline U1344A-15H-6, 134.7 & 140.75 & 163.54 & Tie to & U1344 D-16H-3, 88.7 & 138.54 & 163.54 \\
\hline U1344D-16H-6, 75.5 & 142.72 & 167.71 & Tie to & U1344 A-16H-2, 38.1 & 143.04 & 167.71 \\
\hline U1344A-16H-7, 85.1 & 150.84 & 175.51 & Tie to & U1344 D-17H-4, 15.3 & 149.00 & 175.51 \\
\hline U1344D-17H-7, 25.0 & 153.50 & 180.01 & Tie to & U1344 A-17H-3, 40.1 & 153.82 & 180.01 \\
\hline U1344A-17H-7, 102.1 & 160.27 & 186.46 & Tie to & U1344 E-19H-2, 127.0 & 157.54 & 186.46 \\
\hline U1344E-19H-6, 138.1 & 163.42 & 192.34 & Tie to & U1344 A-18H-3, 142.4 & 164.42 & 192.34 \\
\hline U1344A-18H-7, 64.0 & 169.54 & 197.46 & Tie to & U1344 D-19H-3, 104.3 & 167.33 & 197.46 \\
\hline U1344D-19H-8, 62.5 & 173.23 & 203.36 & Tie to & U1344 A-19H-3, 15.3 & 172.84 & 203.36 \\
\hline U1344A-19H-6, 115.7 & 178.24 & 208.75 & Tie to & U1344 E-21H-2, 5.6 & 175.76 & 208.75 \\
\hline U1344E-21H-5, 71.9 & 180.52 & 213.52 & Tie to & U1344 A-20H-1, 112.2 & 181.22 & 213.52 \\
\hline U1344A-20H-6, 99.0 & 188.25 & 220.55 & Tie to & U1344 E-22H-2, 133.4 & 185.67 & 220.55 \\
\hline U1344E-22H-6, 102.5 & 191.37 & 226.24 & Tie to & U1344 A-21H-2, 113.0 & 191.50 & 226.24 \\
\hline U1344A-21H-6, 100.2 & 196.99 & 231.73 & Tie to & U1344 D-22H-2, 86.5 & 194.28 & 231.73 \\
\hline U1344D-22H-6, 120.0 & 199.84 & 237.29 & Tie to & U1344 A-22H-2, 146.1 & 201.44 & 237.29 \\
\hline U1344A-22H-8, 24.2 & 208.15 & 244.00 & Tie to & U1344 D-23H-3, 43.7 & 205.60 & 244.00 \\
\hline U1344D-23H-6, 59.7 & 210.26 & 248.66 & Tie to & U1344 A-23H-1, 136.6 & 209.97 & 248.66 \\
\hline U1344A-23H-6, 91.3 & 216.76 & 255.46 & Tie to & U1344 D-24H-3, 65.8 & 214.56 & 255.46 \\
\hline U1344D-24H-7, 83.2 & 220.30 & 261.20 & Tie to & U1344 A-24H-4, 19.3 & 222.59 & 261.20 \\
\hline U1344A-24H-6, 7.4 & 225.47 & 264.08 & Tie to & U1344 D-25H-2, 36.4 & 223.06 & 264.08 \\
\hline U1344D-25H-3, 51.3 & 223.92 & 264.94 & Tie to & U1344 A-25H-1, 12.9 & 226.73 & 264.94 \\
\hline U1344A-25H-7, 41.6 & 235.46 & 273.67 & Tie to & U1344 D-27H-1, 12.1 & 234.12 & 273.67 \\
\hline U1344D-27H-5, 7.4 & 239.99 & 279.54 & Tie to & U1344 A-26H-3, 147.8 & 239.01 & 279.54 \\
\hline U1344A-26H-6, 153.6 & 243.55 & 284.08 & Tie to & U1344 D-28H-3, 116.3 & 242.07 & 284.08 \\
\hline U1344D-28H-7, 50.9 & 246.99 & 289.00 & Tie to & U1344 A-27H-2, 42.7 & 246.96 & 289.00 \\
\hline U1344A-27H-7, 59.9 & 253.86 & 295.90 & Tie to & U1344 D-29H-3, 55.1 & 252.05 & 295.90 \\
\hline U1344D-29H-6, 76.0 & 256.72 & 300.57 & Tie to & U1344 A-28X-2, 91.0 & 257.51 & 300.57 \\
\hline U1344A-28X-5, 124.1 & 262.34 & 305.40 & Tie to & U1344 D-30H-2, 40.7 & 259.91 & 305.40 \\
\hline U1344D-30H-6, 73.3 & 266.15 & 311.65 & Tie to & U1344 A-29X-3, 98.9 & 267.59 & 311.65 \\
\hline U1344A-29X-5, 39.1 & 269.54 & 313.60 & Tie to & U1344 D-31H-2, 85.7 & 269.19 & 313.60 \\
\hline U1344D-31H-7, 135.5 & 277.08 & 321.50 & Tie to & U1344 A-30X-5, 12.4 & 278.31 & 321.50 \\
\hline U1344A-30X-6, 15.0 & 279.64 & 322.82 & Tie to & U1344 D-32H-1, 40.0 & 277.40 & 322.82 \\
\hline U1344D-32H-6, 76.1 & 285.23 & 330.65 & Tie to & U1344 A-31X-4, 43.3 & 286.87 & 330.65 \\
\hline U1344A-31X-5, 50.0 & 288.24 & 332.02 & Append to & U1344A-32X, 0.0 & 292.40 & 336.18 \\
\hline
\end{tabular}


Table T22. Temperature data, Site U1344. (See table note.)

\begin{tabular}{lrccc}
\hline Core & $\begin{array}{r}\text { Depth } \\
(\mathrm{mbsf})\end{array}$ & $\begin{array}{c}\text { Thermal resistance } \\
\left(\mathrm{m}^{2} \mathrm{~K} / \mathrm{W}\right)\end{array}$ & $\begin{array}{c}T \\
\left({ }^{\circ} \mathrm{C}\right)\end{array}$ & $\begin{array}{c}T_{\mathrm{s}} \\
\left({ }^{\circ} \mathrm{C}\right)\end{array}$ \\
\hline 323-U1344A- & & & & \\
$5 \mathrm{H}$ & 47.1 & 56.10 & 4.51 & 1.65 \\
$10 \mathrm{H}$ & 94.6 & 110.49 & 7.04 & 1.66 \\
$15 \mathrm{H}$ & 142.1 & 161.06 & 9.57 & 1.65 \\
\hline
\end{tabular}

Note: $T=$ formation temperature, $T_{\mathrm{s}}=$ seafloor temperature. 